\title{
EFEITO DA FERTILIZAÇĀO FOSFATADA, DA CALAGEM E MICRONUTRIENTES NO DESENVOLVIMENTO \\ DE PLANTAS FORRAGEIRAS
}

\author{
VALDINEI TADEU PAULINO \\ Engenheiro Agrônomo
}

Orientador: Prof. Dr. Euripedes Malavolta

Tesè apresentada à Escola Superior de Agricultura "Luiz de Queiroz", da Universidade de são Paulo para obtenção do título de Doutor em Agronomia. Área de Concentração: Solos e Nutrição de Plantas.

\section{PIRACICABA}

Estado de São Paulo - Brasil

$$
\text { MaIo - } 1990
$$


Ficha catalográfica preparada pela Seção de Livros da Divisão de Biblioteca e Documentação - PCAP/USP

Paulino, Valdinei Tádeu

P328e Efeito da fertilização fosfatada, da calagem e micro nutrientes no desenvolvimento de plantas forrageiras. Piracicaba, 1990.

290p. ilus.

Tese - ESALQ

Bibliografia.

1. Adubação fosfatada 2. Micronutriente em planta forrageira - Efeito 3. Planta forrageira - Adubação fos fatada - Efeito 4. Solo - Calagem I. Escola Superior de Agricultura Luiz de Queiroz, Piracicaba

CDD 633.3 


\section{EFEITO DA FERTIL.IZAÇÃO FOSFATADA, DA CALAGEM E MICRONUTRIENTES NO DESENVOLVIMENTO \\ DE PLANTAS FORRAGEIRAS}

\section{VALDINEI TADEU PAULINO}

Aprovado em 18.07.1990

COMISSÃO JULGADORA:

Prof. Dr. Euripedes Malavolta

ESALQ/USP

Prof. Dr. Antonio Enedi Boaretto

CENA/USP

Prof.. Dr. Takashi Muraoka

CENA/USP

Prof. Dr. Moacir Oliveira C. Brasil Sobrinho

ESALQ/USP

Dr. Herbert Barbosa de Mattos

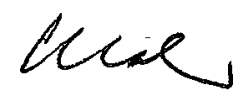

Prof. Dr. Euripedes Malavolta

- Orientador - 
Aos meus pais Joaquim (in memoriam) e Palmyra pela dedicação e incentivo em minha educação.

A minha esposa Josina pelo amor e ajuda prestimosa em todos os momentos.

Aos meus filhos Tiago, Cleber e Cristhian pela alegria e felicidade que sempre me têm dado.

Ofereço 


\section{AGRADECIMENTOS}

Primeiramente, agradeço a Deus pela saúde, sabe doria e perseverança que me deu para execução desse trabalho.

Såo expressos os sinceros agradecimentos:

- Ao Prof. Dr. Eurípedes Malavolta pelas orientações, ensinamentos, atenção e incentivo ao presente trabalho.

- Ao Dr. Ronaldo Mário Barbosa da Silva, Dr. Gilberto Bufarah e Dr. Herbert Barbosa de Mattos pelas facili dades concedidas, oportunidadé de aperfeiçoamento e apoio a realização do trabalho.

- Aos amigos do Instituto de Zootencia, e em es pecial ao Engo Agro PhD Joaquim Carlos Werner pela transmissão de conhecimentos técnicos.

- A Enga Agrạ Eliana Aparecida Schammass, pela colaboração durante as análises estatisticas.

- Aos Senhores Luis Muscio, Antonio Marco Pigato e Senhora Maria Alice Crestani pela ajuda em várias etapas do trabalho.

- As Senhoritas Maria Aparecida de Castro e Lourdes Silvestre, Senhora Neusa Aparecida Chaves Meneghetti e Senhor Francisco Carlos Antoniolli pela colaboração durante às análises laboratoriais.

- A Senhorita Doraci das Dores Soares da Silva pela ajuda na tabulação de dados.

- A Empresa Brasileira de Pesquisa Agropecuária (EMBRAPA) pelo apoio e incentivo.

- A Fundação de Amparo e Pesquisa do Estado dé São Paulo (FAPESP) pelo auxilio financeiro.

- Ao Conselho Nacional de Desenvolvimento Cientifico e Tecnológico pela bolsa concedida. 


\section{SUMARIO}

Página

LISTA DE TABELAS $\ldots \ldots \ldots \ldots \ldots \ldots \ldots \ldots \ldots \ldots \ldots \ldots \ldots \ldots \ldots \ldots \ldots \ldots \ldots \ldots$

RESUMO $\ldots \ldots \ldots \ldots \ldots \ldots \ldots \ldots \ldots \ldots \ldots \ldots \ldots \ldots \ldots \ldots \ldots \ldots \ldots \ldots \ldots \ldots$

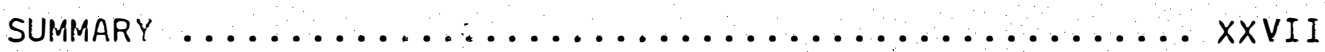

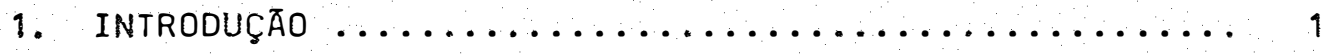

2. REVISÃo DE LITERATURA $\ldots \ldots \ldots \ldots \ldots \ldots \ldots \ldots \ldots \ldots \ldots \ldots \ldots \ldots \ldots \ldots \ldots \ldots$

2.1. Adubação fosfatada $\ldots \ldots \ldots \ldots \ldots \ldots \ldots$

2.2. O fósforo na planta ............ 8

2.3. Respostas de gramineas a adubação fosfata-

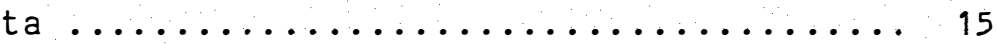

2.4. -Fontes de fósforo $\ldots \ldots \ldots \ldots \ldots \ldots \ldots \ldots \ldots$

2.5. A acidez e a calagem em solos tropicais.

A toxidez de Al e Mn e a disponibilidade

de nutrientes no solo .............. 19

2.6. Calagem para leguminosas forrageiras e efe $\underline{i}$ tos na fixação biológica de nitrogênio ... 23

2.7. Respostas de centrosema à calagem ...... 26

2.8. Respostas de galactia à calagem ....... 27

2.9. Respostas de soja perene à calagem ..... 28

2.10. Calagem para graminea forrageira ...... 29

2.11. Calagem baseada na elevação do indice de saturação em bases .................. 31

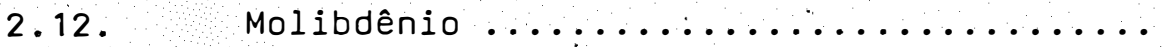

2.13. Ocorrência de deficiência e respostas ao molibdênio ...................... 33

2.14. Molibdênio na planta ............... 34

2.15. Conteúdos de molibdênio ........... 37

2.16. Mo nas sementes e nos nódulos .........37

2.17. Mo no solo ................. 40

2.18. Adubação com molibdênio ...........4 41 
Página

2.19. . Cobalto ....................... 44

2.20. Cobalto na planta ................. 46

2.21. Conteưdos nas plantas e respostas ao cobal

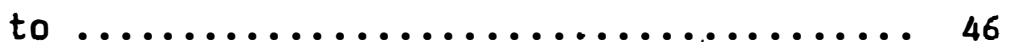

2.22. Cobalto no solo .................. 48

2.23. Fatores que afetam a disponibilidade do

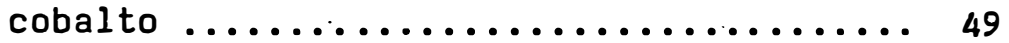

2.24. Fertilização com cobalto ............. 51

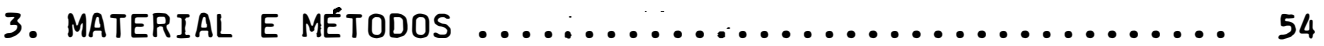

3.1. Local $\ldots \ldots \ldots \ldots \ldots \ldots \ldots \ldots \ldots \ldots \ldots \ldots . \ldots \ldots$

3.2. Espécies estudadas ................. 54

3.2.1. Leguminosas ................ 54

3.2.2. Graminea .................... 54

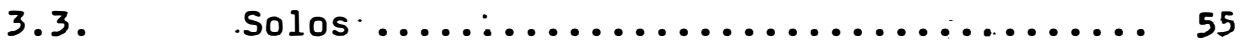

3.4. Procedimento experimental e condiçóes de cultivo ........................... 55

3.5. Delineamento experimental ........... 59

3.6. Colheitas ......................63

3.7. Análises laboratoriais .............. 64

3.7.1. Determinação dos teores de nitrogênio .........................65

3.7.2. Determinação dos teores de $P, K$, $\mathrm{Ca}, \mathrm{Mg}, \mathrm{S}, \mathrm{B}, \mathrm{Cu}, \mathrm{Fe}, \mathrm{Mn}, \mathrm{Zn}, \mathrm{Mo} e$ Co ............................65

3.7.3. Análise do solo ...............66 66

3.7.4. Análises estatisticas ......... 67

4. RESULTADOS E DISCUSSÃO .................... 68

4.1. Crescimento e nitrogênio total acumulado na parte aérea do capim coloniåo ..............66 68 
Página

4.2. Crescimento e nodulação das leguminosas 73

4.2.1. Soja perene cultivada no solo La tossolo Vermelho Escuro álico (LEa) $\ldots \ldots \ldots \ldots \ldots \ldots \ldots \ldots$

4.2.2. Soja perene cultivada no Latossolo Vermelho Amarelo. distrófico $(L V d) \quad \ldots \ldots \ldots \ldots \ldots \ldots \ldots \ldots$

4.2.3. Centrosema cultivada no solo Latossolo Vermelho Escuro álico (LEa $\ldots \ldots \ldots \ldots \ldots \ldots \ldots \ldots$

4.2.4. Centrosema cultivada no solo Latossolo Vermelho Amarelo distrófico $(L V d) \ldots \ldots \ldots \ldots \ldots \ldots \ldots$

4.2.5. Galactia cultivada no solo Latos - solo Vermelho Escuro álico (LEa) 82

4.2.6. Galactia cultivada no solo Latos solo Vermelho Amarelo distrófico (LVd) $\ldots \ldots \ldots \ldots \ldots \ldots \ldots \ldots \ldots \ldots$

4.3. Composiçăo mineral ............... 85

4.3.1. Coloniåo .................. 85

4.3.1.1. Teores de macronutrientes $\ldots \ldots \ldots \ldots \ldots \ldots \ldots$

4.3.1.2. Teores de micronutrientes $\ldots \ldots \ldots \ldots \ldots \ldots$

4.3.2. So.ja perene cultivada no solo. Latossolo Vermelho Escuro álico (LEa) ................... 107

4.3.2.1. Teores de nutrientes .. 107 
Página

4.3.3. Soja periene cultivada no solo Latossolo Vermelho Amarelo distróf $\underline{\underline{i}}$ co $(L V d) \ldots \ldots \ldots \ldots \ldots \ldots . \ldots \ldots 112$

4.3.3.1. Teores de nutrientes ... 112

4.3.4. Centrosema cultivada no solo Latossolo Vermelho Escuro álico (LEa) $\ldots \ldots \ldots \ldots \ldots \ldots \ldots \ldots \ldots \ldots$

4.3.4.1. Teores de nutrientes ... 116

4.3.5. Centrosema cultivada no solo Latossolo Vermelho Amarelo distrófi co $(L V d) . \ldots \ldots \ldots \ldots \ldots \ldots . \ldots \ldots$

4.3.5.1. Teores de nutrientes ... 118

4.3.6. Galactia cultivada no solo Latos solo Vermelho Escuro álico (LEa) $\ldots \ldots \ldots \ldots \ldots \ldots \ldots \ldots \ldots \ldots . \ldots 122$

4.3.6.1. Teores de nutrientes ... 122

4.3.7. Galactia cultivada no solo Latossolo Vermelho Amarerelo distrófico $(L V d) \ldots \ldots \ldots \ldots \ldots \ldots \ldots$

4.3.7.1. Teores de nutrientes ... 126

4.4. Nitrogênio total acumulado .......... 131

4.4.1. Em soja perene ............. 131

4.4.2. Em centrosema ............... 134

4.4.3. Em galactia ................ 137

4.5. Molibdênio nas leguminosas .......... 138

4.5.1. Molibdênio na parte aérea da soja perene ................. 138

4.5.2. Molibdênio na semente da soja perene $\ldots \ldots \ldots \ldots \ldots \ldots \ldots \ldots \ldots \ldots 14$ 
Página

4.5.3. Molibdênio na parte aérea da centrasema

4.5.4. Mólibdênio na semente de cen trosema

4.5.5. Moḷibdênio na parte aérea da galactia

4.5.6. Molibdênio na semente da galactia ............... 145

4.6.

Cobalto nas. leguminosas ......... 145

4.6.1. Cobalto na parte aérea da so ja perene .............. 145

4.6.2. Cobalto na parte aérea da centrosema $\ldots \ldots \ldots \ldots \ldots \ldots$

4.6.3. Cobàlto na parte aérea da ga lactia

5. CONCLUSÕES 


\section{LISTA DE TABELAS}

Tabela 1. Análises granulométrica e química dos solos Latossolo Vermelho-Amarelo distrófico (LVd) e Latossolo Vermelho-Escuro álico (LEa) utilizados nos experimentos. Página 56.

Tabela 2. Quantidade de calcário calcinado empre gadas por vaso e correspondência às quantidades por hectare. Página 58.

Tabela 3. Doses dos nutrientes e respectivas fon tes utilizadas para as leguminosas forrageiras. Página 60.

Tabela 4. Doses de nutrientes e respectivas fontes empregadas no capim colonião. Página 61.

Tabela 5. Datas de corte para as diferentes legu minosas. Página 63.

Tabela 6. Resultados de análise do solo após o cultivo do colonião, em função dos niveis de fósforo e da cala gem. Página 184 .

Tabela 7. Resultados de análises dos solos, sem corretivos e sem fertilizantes antes e após a incubação. Página 185 .

Tabela 8. Resultados de análises dos solos após o cultivo de soja-perene em função dos niveis. de calagem. Médias de doze repetições. Página 186.

Tabela 9. Resultados de análises dos solos após - cultivo da galactia em função dos niveis de calagem. Médias de doze repetições. Página 187.

Tabela 10. Resultados de análises dos solos após o cultivo da centrosema em função, dos niveis de calagem. Médias de doze repetições. Página 188 . 
Tabela 11. Produção de matéria seca a $65^{\circ} \mathrm{C}$ da parte aérea do capim colonião. Médias entre os tratamentos de niveis de fósforo e calagem. Página 189.

Tabela 12. Significâncias do teste $F$ para as pro duções de matérià seca do capim colonião em função doś fatores fósforo, micronutrientes, calagẹm, interações e desdobramentos das interações significativas. Página 190.

Tabela 13. Quantidades totais de nitrogênio acumuladas (mg/vaso), em quatro cortes, na parte aérea do capim colonião em função dos níveis de fósforo na presença ou ausên cia da calagem. Página 191.

Tabela 14. Sigṇificâncias pelo teste $F$ para os desdobramentos das interações significativas de...micronutrientes $x$ adubação fosfatada $e$ análise de regressão para os efèitos do fósforo dentro da aplicạção de micronutrientes. Página 192.

Tabela'15. Significâncias do teste $F$ para as pro duções de matéria seca da parte.aérea (dois cortes), das raízes, da planta inteira, peso seco do número de nódulos da soja -perene cultivada no solo Latossolo Vermelho-Escuro álico em função da calagem, molibdênio, cobalto, interações e desdobramentos das interações significativas. Página 193.

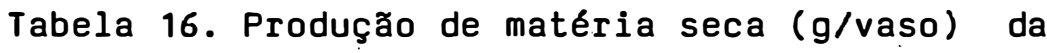
parte aérea, das raízes, da planta inteira e nodulação (mg/vaso e número) da soja perene cultivada no solo Latossolo Vermelho-Escuro em funções dos níveis de calagem. Significância do teste $F$ para os componentes linearmente quadrático. Médias de 12 dados. Página $194^{\circ}$. 
Tabela 17. Equações de regressão para os efeitos de niveis de calagem em função dos tratamentos sem ou com molibdênio ou sem ou com cobalto.'Página 195.

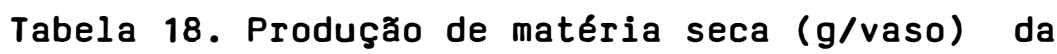
soja-perene cultivada no solo LEa, em funçăo dos niveis de calagem e mediante a aplicação ou não de molibdênio. Página 196.

Tabela 19. Produçåo de matéria.seca ( $g /$ yaso) da parte aérea, das raizes e da planta inteira e nodulaçåo (peso seco, mg/vaso e número de nódulos) de soja-perene cultivada no solo Latossolo Vermelho-Amarelo distrófico em função dos niveis de calagem. Significância do teste $F$ para os componentes linear e quadrático. Página 197.

Tabela 20. Significâncias do teste $F$ para as pro duções de matéria seca da parte aérea (dois cortes), das raizes, da planta inteira e para nodulaçăo (número e peso seco dós nódulos da soja periene cultivada no solo Latossolo ${ }_{3}$ Vermelho-Amarelo álico em funçăo da calagem, molibdênio, cobalto, interaçס̃es e desdobramento das intéraçôes significativas. Pági na 198.

Tabela 2.1. Equaçס̃es de regressåo para os efeitos dos niveis de calagem sobre diversas variáveis em soja perene cultivada no solo Latóssolo Vermelho Amarelo distrófico. Página 199.

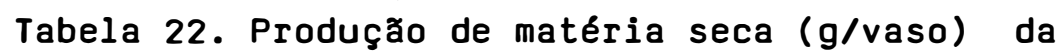
parte aérea, das raizes e da planta inteira e peso seco dos nó dulos (mg/vaso) da centrosema cultivada no solo Latossolo Vermelho-Escuro álico. Significância do teste $F$ para os componentes linear e quadrático. Página 200. 
Tabela 23. Significâncias do teste $F$ para as prọ duções de matéria seca da parte aérea, das raizes, da planta inteira e peso seco dos nódulos da centrosema cultivada no solo Latossolo Vermelho-Escuro álico. Página 201.

Tabela 24. Equaçбes de regressão para os efeitos dos niveis de calagem sobre as diversas variáveis em centrosema cultivada no solo Latossolo Vermelho-Escuro álico.. Página 202.

Tabela 25. Significâncias do teste $F$ paṛa as pro duções de matéria seca da parte aérea, das raizes e da planta inteira e p̃eso seco dos nódulos da centrosema cultivada no solo Latossolo Vermelho-Amarelo distrófico. Página 203.

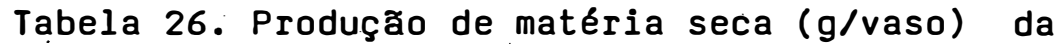
parte aérea, das raizes, da planta inteira e peso secọ dos nódulos (mg/vaso) da centrosema cultivada no solo Latossolo Ver melho-Amarelo distrófič em função dos niveis de calagem. Significâncias do teste $F$ para os componentes linear e quadrático. Página 204.

Tabela 27. Equação de regressão para os efeitos de niveis de calagem sobre as diversas variáveis em centrosema cultivada no solo Latossolo Vermelho-Amarelo. Página 205.

Tabela 28. Significância do teste $F$ para as produções de matéria seca da parte aérea, das raizes, da planta inteira e peso seco dos nódulos da galactia cultivada no solo Latossolo Vermelho-Escuro álico em função da calagem, do molib dênio, do cobalto e das interaçбos e desdobramentos das intera ções significativas. Página 206.

Tabela 29. Produção de matéria seca ( $g / v a s o) ~ d a$ parte aérea, das raizes, da planta inteira e peso seco dos nó- 
dulos (mg/vaso) da galactia cultivada no solo Latossolo Vermelho-Escuro álico em função dos niveis de calagem. Significâncias do teste $F$ para os componentes linear e quadrático. Página 207.

Tabela 30. Equações de regressão para os..efeitos de niveis de calagem sobre as diversas variáveis em galactia cultivada no solo Latossolo Vermelho-Escuro álico. Página 208. Tabela 31. Produção de matéria seca ( $g / v a s o)$ em função dos niveis de calagem e mediante a aplicação ou não de cobalto da galactia cultivada no solo Latossolo Vermelho-Escuro álico. Página 209.

Tabela 32. Significâncias do teste $F$ para as pro duções de matéria seca da parte aérea, das raizes, da planta inteira e peso seco dos nódulos da galactia cultivada no. solo Latossolo Vermelho-Amarelo distrófico em função da calagem, do molibdênio, do cobalto e das interaçðes entre esses fotores. Página 210.

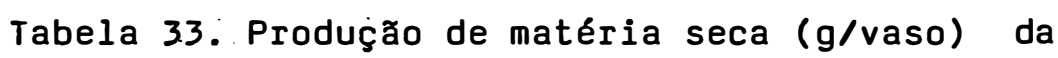
parte aérea, das raizes, e da planta inteira, em ambos os cortes, e nodulação (mg/vaso) da galactia cültivada no solo Latos solo Vermelho-Amarelo distrófico em função dos niveis de calagem.Significâncias do teste $F$ para os componentes linear e quadrática. Médias de 12 dados.. Página 211.

Tabiela: 34. Equações de regressão para os efeitos dos niveis de calagem sobre as diversas variáveis em galactia cultivada no solo Latossolo Vermelho-Amarelo distrófico. Página 212 . 
Tabela 35. Teores de $N, P$ e $K(\%)$ na matéria seca da parte aérea do capim coloniåo para os tratamentos niveis de fósforo e aplicação ou nåo de calagem. Página 213.

Tabela 36. Teores de $\mathrm{Ca}, \mathrm{Mg}$ e $\mathrm{S}(\%)$ na matéria seca da parte aérea do capim coloniåo para os tratamentos niveis de fósforo e aplicação ou não de calagem. Página 214.

Tabela 37. Significâncias para o teste $F$ para os conteúdos de $N, P$ e $K$ na parte aérea do capim colonião. Dados de quatro cortes. Página 215.

Tabela. 38. Equações de regressão para os efeitos de niveis de fósforo $(x)$ sobre diversas variáveis, na presença $\left(\mathrm{Cal}_{1}\right)$ e na ausência de calagem ( $\left.\mathrm{Cal}_{0}\right)$. Págína 216 .

Tabela 39. Equações de regressão para os efeitos dos niveis de fósforo $(x)$ sobre diversas variáveis, na presença $\left(M_{1}\right)$ ou na ausência (Mo) de aplicação de micronutrientes. Página 217 .

Tabela 40. Significância do teste $F$ para os conteúdos de $\mathrm{Ca}, \mathrm{P}$ e $\mathrm{S}$ na parte aérea do capim colónião. Dados de quatro cortes em função dos fatores fósforo, micronutrientes, calagem, interações e desdobramentos das interações significativas. Página 218 .

Tabela 41. Teores de Mg (\%), B, Zn e Mn, em ppm, para os tratamentos de calagem e micronutrientes. Página 219.

Tabela 42. Teores de B, Cu, Fe e $2 n$. (ppm) na matéria seca da parte aérea do capim colonião para os tratamentos niveis de fósforo e aplicação ou não de calagem. Página 220 . 
Tabela 43. Teores de $B, C u$ e $Z n$ (ppm) na matéria seca da parte aérea do capim coloniåo para os tratamentos niveis de fósforo ou não de micronutrientes. Página 221.

Tabela 44. Significânçia do teste $F$ para os:.conteúdos de $B, C u$ e $Z n$ na parte aérea do capim coloniåo. Dados de quatro cortes, em função dos fatores fósforo, micronutrientes, calagem, interaçб̃es e deșobramentos das interações signi ficativas. Página 222.

Tabela 45. Significância do teste $F$ para os conteúdos de Fe e Mn na parte aérea do capim colonião, dados de quatro cortes, em funçăo dos fatores fósforo, micronutrientes, calagem, interaçס̃es e desdobramentos das iṇteraçőes significativas. Página 223.

Tabela 46. Significância do teste $F$ para os conteúdos de molibdênio e de cobalto na parte aérea do capim colo niåo. Dados de quatro cortes em funçåo doṣ fatores fósforo, mí cronutrientes, calagem, interações e desdọbramentos das intera ções significativas. Página 224.

Tabela.47. Teores de molibdệnio ( $\mathrm{ppm}$ ) na matéria seca da parte aérea do capim coloniăo em função dos niveis de fósforo na presença ou ausência de micronutrientes. Página 225.

Tabela 48. Equações de regressåo para os efeitos de níveis de fósforo em funçăo dos tratamentos com ou sem apli caçåo de micronutrientes ou calagem. Página 226.

Tabela 49. Teores de molibdênio e de cobalto

- (ppm) na matéria seca da parte aérea do capim coloniåo, em fun ção da aplicaçåo de niveis de fósforo na presença ou na ausência de calagem. Página 227. 
Tabela 50. Teores de molibdênio ( $\mathrm{ppm}$ ) na matéria seca da parte aérea do capim coloniåo, em funçăo da aplicaçăo de niveis de fósforo e de micronutrientes. Página 228.

Tabela 51. Teores de molibdênio (ppm) na matéria seca da parte aérea do capim coloniåo em funçåo da aplicação ou nåo de calagem na ausência ou na presença de micronutrientes. Página 229 .

Tabela 52. Significâncias para o teste $F$ para os conteúdos de $\mathrm{N}, \mathrm{P}, \mathrm{K}, \mathrm{Ca}, \mathrm{Mg}$ e $\mathrm{S}$ na parte aérea da soja perene cultivada no solo Latossolo Vermelho-Escuro álico. Página 230. parte aérea da soja perene cultivada no solo Latossolo Vermelho-Escuro álico em funçăo dos niveis de calagem. Significâncias do teste $F$ para os componentes linear e quadrático. Médias de 12 dados. Página 231.

Tabela 54. Equaçőes de regressão para os efeitos dos niveis de calagem sobre as diversas variáveis em soja pere ne cultivada no solo Latossolo Vermelho-Escuro. Página 232.

Tabela 55. Teores de $\mathrm{N}, \mathrm{S}(\%)$ e Fe (ppm) em função dos niveis de calagem e mediante a aplicação ou não de cobalto em soja perene cultivada no solo LEa. Página 233.

Tabela 56. Significâncias para o teste $F$ para os conteúdos de $\mathrm{B}, \mathrm{Cu}, \mathrm{Fe}, \mathrm{Mn}$ e $\mathrm{Zn}$ na parte aérea da soja perene cultivada no solo Latossolo Vermelho-Escuro álico. Página 234.

Tabela 57. Teores de B, Cu, Fe, Mn e Zn (ppm) na parte aérea da soja perene cultivada no solo Latossolo Vermelho-Escuro álico, em função dos niveis de calagem. Significância do teste $F$ para os componentes linear e quadrático. Médias de 12 dados iniciais. Página 235. 
Tabela 58. Significância pelo teste $F$ para

conteúdos de N, P, K, Ca, Mg e S na parte aérea da soja perene cultivada no solo Latossolo Vermelho-Amarelo distrófico. Página 236 .

$$
\text { Tabela LVIII. Teores de N, P, K, Ca, Mg e S }
$$

na matéria seca da soja perene, dados de dois cortes, cultivada no solo Latossolo Vermelho-Amarelo distrófico, em função dos niveis de calagem. Significância do teste $F$ para os componentes línear e quadrático. Médias de 12 dados. iniciais. Página 237.

Tabela 59. Teores de B, Cu, Fe, Mn e Zn (ppm) na matéria seca da parte aérea da soja perene, dados de dois cortes, cultivada no solo Latossolo Vermelho-Amarelo distrófico, 'em função dos niveis de calagem. Significância do teste $F$ para os componentes linear e quadrático. Médias de 12 dados Iniciais. Página. 238.

Tabela 60. Significância do teste $F$ para os conteúdos de $\mathrm{B}, \mathrm{Cu}, \mathrm{Fe}, \mathrm{Mn}$ e $\mathrm{Zn}$ na parte aérea da soja . perene cultivada no solo Latossolo Vermelho-Amarelo distrófico. Página 239.

Tabela 61. Significância do teste $F$ para os conteúdos de $N, P, K, C a, M g$ e $S$ na parte aérea da centrosema cul tivada no solo Latossolo Vermelho-Escuro álico. Página 240.

Tabela 62. Teores de N, P, K, Ca, Mg e S (\%) na parte aérea da centrosema, em função dos niveis de calagem, cultivada no solo Latossolo Vermelho-Escuro álico. Significâncias do teste $F$ para os componentes linear e quadrático. Médias de 12 dados iniciais. 
Tabela 63. Significâncias do teste $F$ para

os conteúdos de $B, C u, F e, M n$ e $Z n$ na parte aérea da centrosema cultivada no solo Latossolo Vermelho-Escuro álico.Página 242.

Tabela 64. Teores de B, Cu, Fe, Mn e Zn (ppm) na parte aérea da centrosema, em função dos niveis de calagem, cultivada no solo Latossolo Vermelho-Escuro álico. Signi ficâncias do teste $F$ para os cọmponentes linear e quadrático. Médias de 12 dados. Página 243.

Tabela 65. Equações de regressão para os efeitos de niveis de calagem em função dos tratamentos sem ou com aplicação de Molibdênio ou Cobalto, centrosema cultivada no solo LEa. Página 244.

Tabela 66. Significâncias do teste $F$ para os conteúdos $\mathrm{N}, \mathrm{P}, \mathrm{K}, \mathrm{Ca}, \mathrm{Mg}$ e $\mathrm{S}$ na parte aérea da .centrosema cultivada no solo Latossolo Vermelho-Amarelo distrófico. Pági na 245 .

Tabela 67. Teores de $\mathrm{N}, \mathrm{P}, \mathrm{K}, \mathrm{Ca}, \mathrm{Mg}$ e $\mathrm{S}$ (\%) na parte aérea da centrosema cultivada no solo Latossolo Vermelho-Amarelo distrófico, em função dos niveis de calagem. Significâncias do teste $F$ para os componentes linear e quadrático. Médias de 12 dados. Página 246.

Tabela 68. Teores de nitrogênio (\%), em função dos niveis de caalgem e mediante a aplicação ou não de molibdênio (Mo) ou de çobalto (Co.). Página 247.

Tabela 69. Equações de regressão para os efei- tos dos niveis de calagem em função da aplicação ou não de cobalto ou molibdênio. Página 248.

Tabela 70. Significâncias do teste $F$ para os conteúdos de $\mathrm{B}, \mathrm{Cu}, \mathrm{Fe}, \mathrm{Mn}$ e $\mathrm{Zn}$, na parte aérea da centrosema cultivada no solo Latossolo Vermelho-Amarelo distrófico. Página 249. 
Tabela 71. Teores de B, Cu, Fe, Mn e Zn (ppm) na parte aérea da centrosema cultivada no solo Latossolo Vermelho distrófico, em função dos níveis de calagem. Significân cla do teste $F$ para os componentes linear e quadrático. Média de 12 dados. Página 250.

Tabela 72. Significâncias do teste $F$ para os conteúdos de $\mathrm{N}, \mathrm{P}, \mathrm{K}, \mathrm{Ca}, \mathrm{Mg}$ e $\mathrm{S}$ na parte aérea da galactia cultivada no solo Latossolo Vermelho-Escuro álico. Página 251.

Tabela 73. Teores de N, P, K, Ca, Mg e S na parte aérea da galactia, ẹ função dos niveis de calagem, cultivada no solo Latossolo Vermelho-Escuro álico. Significân cia do teste $F$ para os componentes linear e quadrático. Médias, de 12 dados iniciais. Página 252.

Tabela 74. Teor de Ca (\%) em função dos nîveis de calagem, mediante a-aplicação ou não de molibdênio para ga lactia cultivada no solo Latossolo Vermelho-Escuro álico. Página 253.

Tabela 75. Significânicias do teste $F$ para os conteúdos de B, Cu, Fe, Mn e $\mathrm{Zn}$ na parte aérea da galacita cultivada no solo Latossolo Vermelho-Escuro álico. Página 254 Tabela 76. Teores de B, Cu, Fe, Mn e Zn (ppm) na parte aérea da galactia, em função dos niveis de calagem, cultivada no solo Latossolo Vermelho-Escuro álico. Significân clas do teste $F$ para os componentes linear e quadrático. Médias de 12 dados iniciais. Página 255.

Tabela 77. Teores de zinco (ppm) na parte aérea da galactia cultivada no solo Latossolo Vermelho-Escuro álico em função da aplicação da calagem e de cobalto. Página 256. 
Tabela 78. Significâncias do teste $F$ para os conteúdos de $\mathrm{N}, \mathrm{P}, \mathrm{K}, \mathrm{Ca}, \mathrm{Mg}$ e $\mathrm{S}$ da galactia cultivada no solo Latossolo Vermelho-Amarelo distrófico. Página 257.

Tabela 79. Teores de N, P, K, Ca, Mg e S na matéria seca da parte aérea da galactia, em função dos niveis de calagem, cultivada no Latossolo Vermelho-Amarelo distrófico. Significância do teste $F$ para os componentes. Iinear e quadrático. Médias de 12 dados iniciais. Página 258.

Tabela 80. Teores de Nitrogênio (\%) em galactia cultivada no solo Latossolo Vermelho-Amarelo distrófico, em função dos niveis de calagem é mediante a aplicação ou não de Molibdênio. Dados do segundo corte. Página 259.

Tabela 81. Significâncias do teste $F$ apra os conteúdos de $\mathrm{B}, \mathrm{Cu}, \mathrm{Fe}, \mathrm{Mn}$ e $\mathrm{Zn}$ lna parte aérea da galactia cultivada no solo Latossolo Vermelho-Amarelo distrófico. Pági ná 260.

Tabela 82. Teores de B, $\dot{\mathrm{Cu}}, \mathrm{Fe}, \mathrm{Mn}$ e $\mathrm{Zn}$ (ppm) na matéria seća da parte aérea da galactia, dados de dois cortes, cultivadas no solo Latossolo Vermelho-Amarelo distrófico em função dos níveis de calagem. Significâncias do teste F para os componentes linear e quadrático. Médias de 12 dados. Página 261.

Tabela 83. Teores de zinco (ppm) na parte aérea da galactia cultivada no solo Látossolo Vermelho-Amarelo distrófico, em função dos niveis de calagem e mediante a aplicação ou não de cobalto. Dados do primeiro corte. Página 262.

Tabela 84. Significâncias para o teste $F$ para as quantidades totais de nitrogênio acumuladas na parte aérea da soja-perene cultivada nos solos Latossolo Vermelho-Amarelo distrófico (LVd) e no solo Latossolo Vermelho-Escuro álico (LEa). Página 263. 
Tabela 85. Quantidades totais de nitrogênio acu muladas (mg/vaso) na parte aérea da soja-perene cultivada nos solos Latossolo Vermelho-Amarelo distrófico (LVd) e Latossolo Vermelho-Escuro álico (LEa). Significâncias do teste $F$ para os componentes linear e quadrático. Médias de 12 dados iniciais. Página 264.

Tabela 86. Produção de matéria seca (g/vaso) e quantidades totais de nitrogênio (mg/vaso) da soja-perene cul tivada no solo LEa, em função dos níveis de calagem e median te a aplicação ou não de molibdênio. Página 265.

Tabela 87. Significâncias para o teste $F$ para as quantidades totais de nitrogênio acumuladas na parte aérea da centrosema cultivada nos solos Latossolo Vermelho-Amarelo distrófico (LVd) e no solo Latossolo Vermelho-Escuro áli Co (LEa). Página 266.

Tabela 88. Quantidades totais de nitrogênio acu muladas (mg/vaso) na parte aérea da centrosema cultivada nos solos Latossolo Vermelho-Ámarelo distrófico (LVd) e Latossolo Vermelho-Escuro álico (LEa); em função dos niveis de calagem. Significâncias do teste $F$ para os componentes linear e quadrá tico. Médias de 12 dados iniciais. Página 267.

Tabela 89. Quantidades de nitrogênio acumuladas (mg/vaso) na parte aérea da centrosema, em função da apli cação ou não de Cobalto e Molibdênio. Página 268 .

Tabela 90. Significâncias para o teste $F$ para - as quantidades totais de nitrogênio acumuladas na parte aérea da galactia cultivada nos solos Latossolo Vermelho-Amarelo distrófico (LVd) e no solo Latossolo Vermelho-Escuro álico (LEa). Página 269. 
Tabelà 91. Quantidades totais de nitrogênio acu muladas (mg/vaso) na parte aérea da galactia cultivada nos so los Latossolo Vermelho-Amarelo distrófico (LVd) e no solo La tossolo Vermelho-Escuro álico (LEa), em função dos niveis. de caalgem. Significâncias do teste $F$ para os componentes linear e quadrático. Médias de 12 dados iniciais. Página 270.

Tabela 92. Significâncias do teste $F$ para os conteúdos de molibdênio na parte aérea das leguminosas sojaperene, centrosema e galactia cultivadas nos solos Latossolo Vermelho-Amarelo distrófico (LVd) e no solo Latossolo Vermelho-Escuro álico (LEa). Página 271.

Tabela 93. Teores de molibdênio (ppm) na matéria seca da parte aérea das leguminosas soja-perene, centrosema. è galactia cultivadas nos solas Latossolo Vermelho-Amare 10 distrófico (LVḍ) e no solo Latossolo Vermelho-Escuro álico (LEa) para os tratamentos de niveis de calagem e aplicação ou não de molibdênio. Página 272.

Tabela 94. Significâncias pelo teste $F$ das inte rações calagem $\times$ molibdênio e calagem $\times$ cobalto e das regressőes para os efeitos da calagem dentro da aplicação ou não de molibdênio e da calagem entre ou não da aplicação de cobalto. sobre os conteúdos de molibdênio para as leguminosas forrage ras. Página 273.

Tabela 95. Equações de regressão para os efeitos de niveis de calagem em função dos tratamentos sem ou com apliçação de molibdênio. Página 274 .

Tabela 96. Teores de molibdênio (ppm) na parte aérea da soja-perene e teores de cobalto (ppm) na parte aérea da galactia cultivada nos solos Latossolo Vermelho-Amarelo distrófico (LVd) e Latossolo Vermelho-Escuro álico 
em função da aplicação ou não de molibdênio e de cobalto. Página 275.

Tabela 97. Teores de molibdênio (ppm) na parte aérea da soja-perene, em função da aplicação de calagem e de cobalto, cultivada nos solos Latossolo Vermelho-Amarelo distrófico (LVa) e Latossolo Vermelho-Escuro álico (LEa). Página 276.

Tabela:98. Equações de regressão para os efeitos de: niveis de calagem em função dos tratamentos sem ou com aplicações de cobalto. Página 277.

Tabela 99. Significâncias do teste $F$ para

os

conteúdos de cobalto na parte aérea das leguminosas soja-pere ne, centrosema e galactia cultivadas nos solos Latossolo Vermelho-Amarelo distrófico (LVd) e no Latossolo Vermelho-Escuro álico (LEa). Página 278.

Tabela 100. Teores de cobalto (ppm) na matéria seca da parte aérea das leguminosas soja-perene, centrosema e galactia cultivadas nos solos Latossolo Vermelho-Amarelo distrófico (LVd) e Latossolo Vermelho-Escuro álico (LEa) para os tratamentos de niveis de calagem e aplicação ou não de cobalto. Página 279.

Tabela 101. Significâncias pelo teste $F$ das interações caalgem $x$ molibdênio e calagem $x$ cobalto e das regressões para os efeitos da calagem dentro da aplicação ou não de molibdênio e da calàgem dentro da aplicação ou não de cobalto sobre os conteúdos de cobalto para as leguminosas for rageiras. Página 280.

Tabela 102. Equações de regressão para os efeitos dos niveis de calagem em função de calagem dos tratamentos sem ou com aplicação de cobalto. Página 281. 
EFEITO DA FERTILIZAÇĀO FOSFATADA, DA CALAGEM E MICRONUTRIENTES NO DESENVOLVIMENTO DE PLANTAS FORRAGEIRAS

\author{
Valdinei Tadeü Paulino \\ Orientador: Euripedes Malavolta
}

RESUMO

Com o intuito de eștudar os efeitos de niveis de calagem, da aplicaçåo de micronutrientes (molibdênio e cobalto) sobre a nodulaçăo, fixaçăo de nitrogênio, produção de matéria seca e composiçăo química, foram cultivadas a soja perene. Tinaroo (Neonotonia wightii. (Wightii \& Arn) . Lakey var. Tinaroo), centrosema (Centrosema pubescens Benth). e galactia (Galactia striata (Jacq) Urb.) nos solos Latossolo Ver melho-Amarelo distrófico (LVd) e no solo Latossolo VermelhoEscuro álico (LEa). Foram também avaliados os efeitos da adubação fosfatada e do uso de micronutrientes, com ou sem correçåo de acidez, no cultivo do capim coloniåo (Panicum maximum Jacq. cv. IZ-I) no solo Latossolo Vermelho-Amarelo distrófico.

Para as leguminosas foram aplicados três niveis de calagem (correspondentes a zero; calagem para elevaçåo do indice de saturaçåo em bases dos solos a 35\%, e um nível máximo para elevaçăo do indice de saturaçăo em bases a 70\%). 
Em experimentos conduzidos em vasos, foram distribuidos os do ze tratamentos dispostos em blocos ao acaso, com quatro repetiçờes •

No experimentio com capim-coloniăo, ou nåo se aplicou calcário ou foi aplicado para elevação do indice de saturação em bases a 70\%, ẹm presença ou ausência de micronu trientes e três níveis de fósforo $(20 ;: 100$ e 200 ppm de 1 :P) combinados em arranjo fatorial, em blocos ao acaso com quatro repetições.

Foram avaliádos os efeitos dos tratamentos nos solos sobre suas principais caracteristicas quimicas e, nas plantas, produções de matéria seca (dois cortes para as leguminosas e quatro para o capim coloniåo) da parte aérea é das rậzes, nodulaçåo nas leguminosas, teores de nutrientes na parte aérea dessas forrageiras.

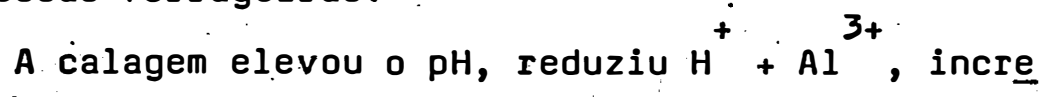
mentando os teores de cálcio e de magnésio trocáveis, e e a pọ centagem de saturação em bases do solo, tanto no solo LVd cul tivado com capim coloniăo como no's sọlos LVd e LEa cultivado com as leguminosas. A adubaçăo fosfatada elevou significativamente as produções de matéria seca, quantidades totais de nitrogênio e teores de fósforo no capim-coloniåo, sendo que a calagem aumentou a eficiência do fósforo aplicado.

A nåo aplicaçåo 'de micronutrientes limitou o crescimento do capim-coloniăo a partir do terceiro corte. A calagem, aumentando o pH, melhorou a disponibilidade do molib dênio aplicado, resultando em maiores acumulações de Mo na parte aérea do coloniåo.

A produçåo de matéria seca na parte aérea, nas raizes e na planta inteira, nitrogênio total e nodulaçăo da 
soja perene, da centrosema e da galactia foram significativamente aumentadas pela aplicação de níveis de calagem, quando cultivadas em ambos solos.

o emprego do molibdênio resultou em efeitos favoráveis sobre as quantidades de nitrogênio acumuladas na par te aérea da soja perene, da centrosema e da' galactia cultivadas no solo LEa. Beneficiando a fixação biológica de nitrogênio, a aplicação de molibdênio resultou em acréscimos na produção de matéria seca da soja perene no primeiro corte e da galactia, cultivadas no solo LEa.

A utilização conjunta do cobalto e molibdênio correspondeu a maiores acumulações de nitrogênio na matéria seca da parte aérea do segundo corte da centrosema no solo LEa. O emprego do cobalto aumentou expressivamente o peso seco dos nódulos da centrosema cultivada no solo LEa. Na ausên cia da calagem, o cobalto favoreceu a produçåo de matéria seca da centrosema no solo, dados do primeiro corte. A calagem resultou em variações significativas na composição mineral das três leguminosas testadas, sendo que a aplicação de molibdênio e de cobalto incrementou significativamente os teores desses micronutrientes. A caliagem favoreceu a absorção de mo libdênio, porém diminuiu as de cobalto. 
PHOSPHATIC FERTILIZATION, LIME AND MICRONUTRIENTS ON FORAGE DEVELOPMENT

Author: Valdinei Tadeu Paulino Adviser: Prof. Dr. Euripedes Malavolta

SUMMARY

The effects of lime and micronutrients (molybdenum and cobalt) application on nodulation, nitrogen fixation, growth and chemical composition were evaluated in perennial soybean Tinaroo (Neonotonia wightii. (Wightii \& AIn) Labey cv. Tinaroo) centro (Centrosema pubescens Benth) and galactia (Galactia striata (Jacq) Urb.) cultivated in distrofic Red Yellow Latosol (RYL) and alic Red Dark Latosol (RDL) soils. The influences of phosphate fertilization and micronutrients, with or without lime, in guinea grass (Panicum maximum Jacq. cv. IZ-1) in distrofic Red Yellow Latosol soil, were also studied. Three levels of lime were applied for the legumes (equivalent to zero, lime to raise the base saturation in dex of soils to $35 \%$ and higher level to raise this index to 70\%). Thelve treatments were arranged in randomized complete block design with four replications in pot trials.

The trial with guinea grass, with or with out lime, in order to raise the base saturation index of soils to $70 \%$, in the presence or absence of micronutrients and three 
levels of phosphorus $\left(P_{1}=20, P_{2}=100\right.$ and $P_{3}=200$ ppm of $P$ ) was combined in factorial arrangement, in randomized complete bocks design with four replications.

The treatment effects in the soils were evaluated upon its main chemical characteristics and, in the plants upon its dry matter production (two cuts for the legumes and four cuts for guinea grass) of shoots and roots, nodulation in the legumes and nutrient contents in the shoots of these forage plants.

Lime raised the $\mathrm{pH}$, decreased $\mathrm{H}^{+}=\mathrm{Al}^{3+}$, increasing exchangeable $\mathrm{Ca}$ and $\mathrm{Mg}$ contents and soil base saturation percentage, either in RYL soil cultivated with guinea grass as in RYL and RDL soils cultivated with the legumes. The phosphate fertilization increased significantly the dry matter production, the total quantities of nitrogen and the phosphorus content on guinea grass, while lime increased the phosphorus efficiency applied.

Without micronutrients application, the growth of guinea grass was limited after the third cut. Lime increasing the $\mathrm{pH}$, the molybdenum availability, resulting in higher Mo accumulations in guinea grass shoots. The dry matter production of shoots roots and whole plant, total nitrogen and perennial soybean, centro and galactia nodulation were significantly increased by the application of lime levels, when cultivated in both soils.

The use of molybdenum resulted in

favourable effects upon nitrogen quantities accumulated on perennial soybean, centrosema and galactia shoots, cultivated in RDL soil. Benefitting the nitrogen biological fixation, the mo- 
lybdenum application resulted in increases in the dry matter production of perennial soybean in the first cut and of galac tia, both of them cultivated in a RDL soil.

The utilization of both cobalt and molybdenum correspondend to higher nitrogen accumulations in the shoot dry matter in the second cut of centrosema in a RDL soil. In the absence of lime, cobalt favoured the dry matter production of centrosema in the soil in the first cut. Lime resulted in significant variations in the mineral composition of the three legumes, while che molybdenum and cobalt applications in creased significantly the contents of these micronutrients. Li me favoured the absorption of molybdenum, but decreased cobalt absorption. 
1. INTRQ̣ODUÇÃO

A produção aniimal baseada em pastagens é um sistema capaz de fornecer. proteina de boa qualidade a baixo custo, e é missão da pesquisa entender e ensinar as técnicas capazes de garantir este objetivo.

Não há proteina sem nitrogênio, e o seu fluxó nas pastagens é feito do solo para as forrageiras e destas para o animal em pastejo, que é transferida para os produtos animais. Nas condições das pastagens tropicais a liberação do nitrogênio, através da mineralização da matéria orgânica, é freqüentemente insuficiente para atender às necessidades da produção. Então, só é possivel manter a produção em bom nivel, através da adição de. $N$ no sistema.

As pesquisas realizadas com fertilizantes nitrogenados para produção animal em pastagens tropicais mostraram respostas animadoras, quando são usados com gramíneas adequadas (Cynodon, Digitaria, Panicum, Pennisetum e Paspa. lum, por exemplo), porém a relação entre o preço pago pelo fertilizante e o obtido pelo produto animal tem se mostrado desfavorável. 
Por outro lado, a fixação biológica do nitrogê nio atmosférico pelas leguminosas forrageiras, capazes de convertê-lo em amônia, uma forma solúvel de nitrogênio, pron tamente utilizada pelas plantas, representa uma alternativa econômica com resultados promissores e mensuráveis, tanto em termos forrageiros, quanto em produção animal.

As áreas destinadas às atividades pecuárias ocorrem predominantemente em condições de solos de cerrado, que são naturalmente ácidos e pobres em nutrientes minerais.

Nessas condições, há dois pontos de fundamental importância para o sucesso no estabelecimento e manutenção das pastagens altamente produtivas: o primeiro deles é a adequação das espécies utilizadas às condições de acidez, e o outro é a adequada nutrição mineral. Esses dois aspectos estão bastante entrelaçados, -e seus equacionamentos, em estudos agrupados, resultariam em respostas que viriam a solucionar os dois problemas.

Os fatores de acidez do solo limitam o desenvolvimento das plantas e a fixação biológica de nitrogênio pelas leguminosas forrageiras.

Em 1961, ANDREW \& NORRIS realizaram estudos com um grupo de leguminosas de clima tropical e com outro grupo de leguminosas de clima temperado, em casa-de-vegetação, com um solo marcadamente deficiente em Ca, e concluiram que, mediante a aplicação de cálcio $\left(\mathrm{CaCO}_{3}\right)$, as tropicais apresentaram muito maior capacidade de extrair Ca do solo do que as temperadas. Porém, embora em menor intensidade que as temperadas, as leguminosas tropicais também responderam à aplicação de $\mathrm{CaCO}_{3}$.

As forrageiras tropicais diferem na sua capaci 
dade de crescimento, nodulação e máxima produção de nitrogênio, sob valores variáveis de $\mathrm{pH}$ e suprimento de cálcio ( $A N-$ DREW, 1978).

MUNNS \& FOX (1977) estudaram comparativamente as respostas à.calagem apresentadas por leguminosas tropicais e temperadas, em experimento de campo, onde $\mathrm{CaCO}_{3}$ foi aplicado em um oxisol deficiente em nitrogênio, com problemas de excesso de $M$, baixa saturação em Ca, mas sem problemas de toxidez de Al. No geral, as curvas da resposta à calàgem não apresentaram distintas diferenças entre as leguminosas de clima tropical e temperado. Porém, dentro de cada grupo, houve acentuadas diferenças entre as espécies.

Há indicação; na literatura, de que as gramineas tropicais não respondem, ou respondem muïto pouco, à ca lagem (SPAIN et alii, 1975, SIQUEIRA et alii, 1980). Usualmente o crescimento máximo é atingido com a aplicação de pequenas quantidades de calcário da ordem de 0,15 e $1,0 \mathrm{t}$ de $\mathrm{CaCO}_{3} / \mathrm{ha}$, que não modifica necessariamente os valores de $\mathrm{pH}$ ou a saturação de aluminio, porém proporciona $\mathrm{Ca}$ e $\mathrm{Mg}$ às plantas.

Embora se saiba que a acidez seja um fator limitante ao crescimento das plantas em solos de cerrado, é também bastante conhecida a deficiêncià de nutrientes minerais nesses solos, sendo que o fósforo é o que apresenta maio res deficits, seguido pelo cálcio, pelo magnésio e pelos micronutrientes.

Os efeitos benéficos da adição de $P$ ao solo, sobre a produção, nodulação e fixação de $\mathrm{N}$ por leguminosas tropicais, tem sido demonstrado por diversos autores (JONES, 1968; SOUTO \& DOBEREINER, 1.968; JONES et alii, 1970; BRUCE \& 
- TEITZEL, 1978). WOODHOUSE (1964) ressalta que, no plantio, os capins exigem e respondem melhor à aplicação de $P$ que as leguminosas, crescendo e se estabelecendo mais rapidamente que estas; quando bem adubados com este elemento.

Um dos principais efeitos da aplicação do calcário em solos ácidos é aumentar a disponibilidade de $\mathrm{P}$ e do micronútriente molibdênio para as plạntas.

É reconhecido que a deficiência de micronutrientes pode constituir um grande problema de fertilidade em solos tropicais, ou mesmo, quando presentes, esses micronutrientes,

1 como por exemplo o molibdênio, pode estar indisponivel às plan tas, por estar adsorvido às particulas do solo.

0 molibdênio é, sem dúvida, o mais importante micronutriente para as leguminosas, em pelo menos duas fases fundamentais da nutrição: primeiro, no eficiente funcionamento do Rhizobium, sendo componente da enzima nitrogenase, responsável pela fixação biológica do nitrogênio, e, em segundo lugar, na transformação do nitrogênio nitrato em nitrogênio amoniacal. A quantidade requerida de molibdênio no processo de fixação é maior que a exigida pela própria planta (ANDREW, 1962).

Outro micronutriente descrito como essencial para as plantas dependentes da fixação simbiótica de nitrogênio é o cobalto, atuando como componente de coenzimas responsáveis pela sintese de leg-hemoglobina (REISENAUER, 1960). Cumpre ressaltar que pouco se conhece sobre esse micronutriente, espe cialmente com dados experimentais sobre sua importância em solos de regiões tropicais. 
Diante do nivel atual de conhecimento na área de nutrição de plantas, fica evidente a importância de estudar os efeitos da calagem, da adubação fosfatada e do uso dos micronutrientes cobalto e molibdênio e das interações entre esses nutrientes sobre as leguminosas e gramineas forrageiras.

o presente trabalho teve por objetivo:

- determinar os efeitos de niveis de calagem na nodulação, fixação de nitrogênio e produção de matéria seca de três leguminosas forrageiras; cultivadas em dois solos tipi cos de cerrado do Estado de São Paulo;

- avaliar os efeitos da presença ou ausência dos micronutrientes molibdênio e cobalto na produção de matéria se ca, nodulação e fixação de nitrogênio de três leguminosas;

- medir os efeitos da calagem nos niveis de nutrientes na matéria seca $(\mathrm{N}, \mathrm{P}, \mathrm{K}, \mathrm{Ca}, \mathrm{Mg}, \mathrm{S}, \mathrm{B}, \mathrm{Co}, \mathrm{Cu}, \mathrm{Fe}$, Mo, Mn e $Z n$ ) e na disponibilidade de $P, K$, Ca, Mg e $H+A l$ no solo, através das determinações desses nutrientes nas plantas e no solo;

- avaliar os efeitos da adubação fosfatada e do uso de micronutrientes, com e sem correção de acidez, no cultị vo de uma graminea exclusiva em termos de produção de matéria; conteúdos de nitrogênio e composição química;

- observar possiveis alterações quimicas ocorridas no solo em função do emprego do calcário calcinado e da adubação fosfatada. 
2. REVISÃO DE LITERATURA

2.1. Adubação Fosfatada,

A maioria dos solos tropicais såo altamente intemperizados, sendo freqüentemente deficientes em fósforo, constituindo-se assim em sérios problemas no estabelecimento de pastagens. Estes solos são comumente ácidos, contendo ele vadas quantidades de óxidos è hidróxidos de ferro e aluminio, os quais acarretam a rápida fixaçåo da forma solúveis de fósforo, tais como superfosfato simples e superfosfato triplo (SALINAS \& SANCHEZ, 1976; FOY, 1976; FENSTER \& LEON, 1978).

0. baixo teor de fósforo disponivel comprome te nåo apenas o estabelecimento das plantas forrageiras, como também afeta sua produtividade e valor nutritivo, prejudi cando o desempenho animal.

A carência de fósforo causa distúrbios imediatos e severos no metabolismo e desenvolvimento das plantas (EPSTEIN, 1975). O baixo teor de fósforo na planta prejudica a nutriçăo dos ruminantes, por nåo atender às exigências mé- 
dias em fósforo para os animais adultos, que såo de $0,20 \%$, e principalmente para animais novos que são de $0,34 \%$ (NATIONAL ACADEMY OF SCIENCE, 1970).

A importåncia da adubação fosfatada para o estabelecimento e produtividade das espécies forrageiras é res saltada em diversos trabalhos (ANDREW \& ROBINS, 1969); MONTEIRO \& WERNER, 1977; GUSS et alii, 1981 e COSTA et alii, 1983).

WERNER \& HAAG (1972) observaram sintomas nitidos de deficiência de fósforo em capim-colonião (Panicum maximum Jacq.), capim-gordura (Melinis munitiflora capim-jaraguá (Hyparrhenia rufa (Ness) Stapf.) e capim- elefante Napier (Pennisetum purpureum Schum.), cultivados em solução nutritiva com baixos niveis desse elemento. Verifica ram ainda que a deficiência de fósforo prejudicou o perfilina mento e o desenvolvimento radicular.

WERNER et alii (1967) obtiveram aumentos de 117\% na produção de matéria seca de capim-colonião, cultivado em vasos com solo pobre em fósforo, utilizando adubação fosfatada, enquanto GOMIDE (1975) obteve para essa graminea um aumento percentual de $35 \%$ com esse tipo de adubação.

Embora a adubação fosfatada propicie aumentos na produção forrageira, seu efeito sobre'a concentração de fósforo na matéria seca tem se.mostrado ora positivo (ANDREW \& ROBINS, 1969 ; oŕa nulo (GOMIDE, 1975).

COSTA et alii (1983), estudando os efeitos de doses de fósforo sobre o crescimento e teor de $\mathrm{P}$ do capimcoloniåo, obtiveram aumento na produção de matéria seca com a adubaçăo fosfatada. O maior incremento foi obtido com a adição de 50 ppm de $P$ e a produtividade máxima com a . adição 
de 250 ppm de P ao solo. Verificaram, no entanto, que somente com altas doses de $P$ foi possivel elevar a concentraçăo desse elemento na matéria seca das gramineas ao nivel das exigências da nutriçăo de ruminantes.

ANDREW \& ROBINS ( 1969) estabeleceram os seguin tes valores para o nivel critico de fósforo: capim-coloniăo $0,20 \%$, capim-gordura $0,18 \%$, capim-pangola $0,16 \%$ e capim- buf fel $0,25 \%$.

SMITH (1975) verificou a possibilidade de se determinar o estado nutricional em fósforo do capim greenpanic (Panicum maximum Jaccq. var.. trichoglume cv. Petrie), através da determinação do nivel critico, amostrando pára fins de diagnose as "folhas novas", ou sejä, aquelas que apresentam a lâmina foliar totalmente expandida e com a lígu la aparente. Os valores obtidos decresceram com a idade da planta, de $0 ; 55 \%$, com 3 a 4 folhas, para $0,32 \%$, com 4 a 5 folhas, e 0,15\%, com 6 folhas.

COSTA et alii (1983), estudando os niveis criticos de fósforo no capimłjaraguá e no capim-coloniåo, obser varam que esses valores variaram de 0,31 a $0,40 \%$ de $P$, para a primeira graminea, e de 0,29 a 0,45\%, para a segunda.

MARTINEZ \& HAAG (1980) encontiraram os seguintes niveis criticos de fósforo para as gramineas tropicais cultivadas em soluçăo nutritiva: coloniăo $0,24 \%$, braquiária decumbens $0,32 \%$, braquiária humidicola $0,26 \%$, capim-jaraguá de $0,18 \%$ a $0,59 \%$.

\subsection{O Fósforo na Planta}

0 ácido fosfórico dá por dissoçiaçăo três espé cies iônicas diferentes: $\mathrm{H}_{2} \mathrm{PO}_{4}^{-}, \mathrm{HPO}_{4}^{-2}$ e $\mathrm{PO}_{4}^{-3}$. A primeira 
predomina na faixa de $\mathrm{pH} 4,0$.a 8,0, comumente encontrado no solo. A absorção de $\mathrm{H}_{2} \mathrm{PO}_{4}^{-}$é influenciada pela concentraçåo de magnésio no meio; o efeito é sinergistico. Foi verificado em raizes de cevada que, quando $\mathrm{H}_{2} \mathrm{PO}_{4}^{-}$estava numa concentra ção da $5 \times 10^{-5} \mathrm{M}$, a elevação da concentração de magnésio até o mesmo valor provoca aumento na absorção de fósforo. Aumentando-se ainda mais a concentração de magnésio havia diminui ção na concentração de fósforo (MALAVOLTA, 1976).

No xilema a maior concentração de fósforo se encontra na forma inorgânica; $\left(\mathrm{H}_{2} \mathrm{PO}_{4}^{-}\right)$, mas este mineral também participa de compostos orgânicos como a fosforil-colina e ésteres de carboidrato. A maior parte de fósforo inorgânico da célula parece estar armazenada no vacúolo de onde nåo sai com facilidade. Ainda assim ocorre transporte dos órgãos mais velhos para os mais novos. Frutos e sementes são acumuladores de fósforo. o ácido fitico é uma forma de reserva do elemento (MALAVOLTA, 1976).

Sob a forma de fosfato orgânico, o fósforo se encontra no citoplasma e núcleo celulares dos tecidos jovens, cujas células se encontram em intenso metabolismo. É um elemento indispensável à fotossintese, sintese de ligações ricas em energia, sintese e degradação dos carboidratos (GOMIDE, 1975). Participa de importantes reaçðes na biossintese de proteinas, sendo constituinte de coenzimas que parti cipam nas reaçơes de transaminação. É importante para o desenvolvimento radicular e para o crescimento e divisão das células. Tende por isso a concentrar-se nos tecidos jovens, que são os mais apeteciveis e nutritivos (COMASTRI . FILHO, 1977).

É o elemento mais importante para as pasta- 
gens, após o nitrogênio, principalmente nos perlodos iniciais da vida da planta, quando esta o absorve em : grandes quantidades. Exerce grande influência no perfilhamento e crescimento das rafzes. Assim, a falta de fósforo determina, no campo, o aparecimento de espaços vazios, que văo ser ocupados pelas invasoras, espécies menos exigentes.

WERNER e HAAG (1972) descrevem os sintomas de deficiência de fósforo nos capins-napier, gordura, jaraguá e coloniåo. De modo geral as plantas deficientes apresentaram -se pouco desenvolvidas, raquiticas e com peifilhamento redu zido; os perfilhos produzidos apresentavam um aspecto enfeza do. As folhas inferiores apresentavam-se totalmente secas. Algumas folhas intermediárias apresentavam coloraçăo verdepálida, na base, e laivos arroxeados, nas pontas; outras apresentavam coloraçåo totalmente arroxeada.e com as pontas secas. Folhas mais novas de alguns perfilhos apresentavam laivos arroxeados contra coloração verde aparentemente normal. Todas, entretanto, eram de tamanho reduzido. Por vezes, as folhas apresentavam coloraçăo verde-amarelada, e havia secamento intenso das mais velhas, iniciando-se nas pontas e caminhando em direção à base; sendo mais pronunciado nos bordos. Os sintomas estendiam-se às bainhas, e, por vezes, os colmos apresentavam-se endurecidos, tortuosos e quebradiços. 0 sistema radicular mostrava-se pouco desenvolvido, com número reduzido de raizes muito compridas, delgadas e com poucos pêlos absorventes.

MALAVOLTA et alii (1974) relatam ainda coloração verde, mais escura nas folhas, e diâmetro reduzido dos colmos. MALAVOLTA (1976) relata o aumento no conteúdo de carboidratos e na relação fósforo inorgânico/fósforo orgâni- 
co, além de restrição na diferenciação dos cäules.

0 teor de fósforo em diversas gramineas tropicais decresce com o aumento da idade, podendo esse decréscimo ser mais ou menos acentuado. Há também diferenças quanto à parte da planta considerada, sendo as folhas mais, ricas no elemento que o caule (HAAG et alii, 1967). GOMIDE (1976) relata que a idade afeta o valor nutritivo e a composição qui-mica da forrageira devido à distribuição diferencial • dos elementos nos diversos órgãos vegetais, mudança nas relações caule/folha, efeito de diluiçăo e diminuiçăo na capacidade das plantas absorverem nutrientes.

GOMIDE (1976), HAAG et lii (1967), NASCIMENTO JUNIOR et alii (1976) e PRÓSPERO e PEIXOTO (1972), trabalhan do com os capins coloniåo, pangola, gordura, jaraguá e napier, concordam e relatam que, de maneira geral, o teor de fósforo decresceu com a idade da planta para haste, folha $e$ planta inteira.

ACIOLY (1982), por sua vez, coletou cem gramineas nativas e exóticas, na regiåo de fortaleza (CE), na pri meira quinzena de janeiro, analisando os teores de fósforo, na matéria seca da parte aérea. Seus teores variaram de 0,10 a $0,49 \%$, estando apenas $31 \%$ delas com nivel superior a $0,40 \%$. Oitenta e seis por cento das gramineas apresentavam-se deficientes para atender às exigências animais. SOUZA et alii (1979) fizeram um levantamento das deficiências minerais em seis fazendas do norte de Mato Grosso, baseando-se em análises de amostras de solo, plantas forrageiras e tecido animal. Os teores de fósforo nos solos estudados foram considerados entre médio e baixo $(2,9$ a $27,6 \mathrm{ppm})$. As análises de fósforo das forrageiras indicaram que nenhuma dentre as gra- 
mineas fornecia quantidade adequada de fósfṑo para um minimo de produção animal. Quanto às épocas, observaram-se teores da ordem de 0,20\%, na época chuvosa, e 0,08\%, na época seca. GAVILLON e QUADROS (1970) estudaram a variação anual nos teores de cálcio e fósforo de pastagens nativas no Rio Grande do Sul. Observaram que os teores de fósforo variavam de 0,11 a $0,16 \%$, chegando a ser menor que $0,10 \%$ em algumas regiőes. No veråo, por sua vez, predominavam teores deficien tes, raramente maiores que $0,10 \%$. Esses resultados indicam cárência de fósforo, generalizada para os animais em crescimento e produçåo. Finalizando, TOKARNIA e DOBEREINER (1976) fizeram uma revisão sobre o assunto e encontraram relatos de deficiência generalizada de fósforo em bovinos por todo o território nacional.

o fósforo é referido por inúmeros autores como elemento que incrementa a produçåo de matéria seca das forragens (VICENTE CHANDLER, 1974). SANCHEZ (1976) indica ainda que o grande potencial de resposta ao nitrogênio das gramineas tropicais fica limitado na ausência de fósforo. Segundo GOMIDE (1975), o fósforo afeta também a formaçåo de gemas ba sais e elongaçåo dos caules. FRANÇA et alii (1974) mencionam ainda seu efeito positivo sobre o stand e a produçåo de proteina brutá por hectare.

HAAG et alii (1967) observaram que a extração de fósforo em gramas/kg MS variou entre diversas espécies forrageiras, sendo de 1,77 no capim-pangola, 1,88 no capimnapier, 1,94 no capim-jaraguá, 2,14 no capim-gordura e 2,24 no capim-coloniåo. A extraçăo em g/vaso foi maior para o capim-coloniåo, seguindo-se em ordem decrescente os capins jaraguá, gordura, napier e pangola. Vicente-Chandler ${ }^{1}$ et alii 
(1974), citados por SANCHEZ (1976), relataram uma extração anual variando de 53 a $72 \mathrm{~kg}$ de fósforo/ha/ano. 0 fósforo, quantitativamente, é extraído em maiores quantidades que Mg e $S$ apenas (HAAG et alii, 1967).

Para aumentar a eficiência da fertilização fos fatada, é possivel selecionar plantas que tenham exigências de $P$-mais baixas, para um crescimento máximo, que as plantas geralmente utilizadas. Felizmente, a tolerância 'ao Al e a tolerância a baixos conteúdos de $P$ ocorrem muitas vezes $\underline{s}$ mültaneamente, pois parecem estar relacionados com a capacidade da planta em absorver e de translocar o $P$ das raizes pa ra a parte aérea, em presença de altos niveis de Al na solução do solo e nos tecídos da raiz (SALINAS, 1978).

SALINAS e SANCHEZ (1976) procederam revisão de literatura sobre diferenças entre capins e variedades, em relação à tolerância a baixos niveis de fósforo disponivel no solo. Existem evidências de que ocorrem diferenças consideráveis entre espécies, com respeito ao nivel critico exter no de fósforo (quantidade de fósforo na solução do solo rela cionada a altas produções) e ao nivel crítico interno de fós foro (quantidade de fósforo na planta relacionada a altas produçőes). Em pastagens tropicais Melinis minutiflora e Panicum maximum são espécies mais tolerantes que Chloris gaya"na e Paspalum dilatatum. Segundo for (1976), a literatura menciona cinco mecanismos para explicar as diferenças ao Al tóxico e maior capacidade de sobreviver em solos pobres em $P$, sendo eles: extensão das raizes, exudação das raízes, influência de fungos micorrizicos, equilibrio de nutrientes e diferenças nas taxas de absorção e translocação do fósforo, em relação às taxas de crescimento. 
(1969), na Austrália, mos traram a existência de diferentes niveis criticos de fósforo. Panicum maximum 0,19\%, Digitaria decumbens $0,16 \%$, Paspalum dilatatum 0,25\%, Chloris gayana var: Pioner $0,23 \%$ e Melinis minutiflora $0,18 \%$.

FALADE (1975), na Nigéria, determinou o nivel crítico interno de fósforo e a quantidade de $\mathrm{P}_{2} \mathrm{O}_{5}$ aplicado, que proporcionaram máxima produçåo, em diversas gramineas forrageiras. 0 autor usou, entre outras, duas variedades de Pennisetum purpureum, verificando diferenças na necessidade interna de fósforo de ambas, sendo o $\underline{P}$. purpureum green $(0,21 \%$ de $P)$ mais eficientè quie o $\underline{P}$. purpureum purple $(0,25 \%$ dẹ $P$ ), em termos de uso de fósforo, e o i i i.Panjcum maximum $0,19 \% \cdot d e P$ ).

MARTINEZ e HAAG (1980) determinaram os niveis criticos internos e externos de fósforo nos capims Brachiaria decumbens; B. humidícola, pangola, jaraguá, gordựa, coloniăo e napier, em solução nütritiva. Os autores observaram que as espécies diferiram quanto à necessidade externa de fósforo, sendo B. humidícola e jaraguá as menos exigentes. os niveis criticos internos também variaram entre as espécies, sendo $0,38 \%$, no capim pangola, $0,32 \%$, em $\underline{B}$. decumbens,

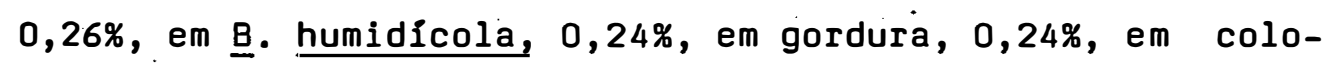
niåo, 0,20\%, em napier. Considerando-se os niveis criticos internos e externos, bem como a produção de matéria seca, a B. humidicola foi a espécie que apresentou maior eficiência na absorção do fósforo.

COSTA et alii (1983) verificaram que a adubação fosfatada propiciou aumento na produçăo de matéria seca dos capins coloniåo e jaraguá. 0 maior incremento foi obtido 
com a adiçăo de 50 ppm de P, e a máxima produtividade, com a adição de aproximadamente 250 ppm de $P$ ao solo. Os autores observaram que apenas altas doses de fósforo elevaram a concentração desse elemento na matéria seca das gramíneas ao ní vel de exigência dos ruminantes, em torno de $0,30 \%$. Os niveis criticos de fósforo variaram de 0,31 a 0,40\%, para o ca pim-jaraguá, e de 0,29 a $0,45 \%$, para o capim-coloniăo.

\section{:i.3. Respostas de Gramineas à Adubaçăo Fosfatada}

A literatura relata trabalhos em que i.l houve resposta ao fósforo, na quase totalidade do território nacio na-l.

WERNER et alii (1967) realizaram um experimento com capim-coloniăo, em vasos, usando solos da regiăo noroeste do Estado de Săo Paulo, pobres em fósforo. Obtiveram aumentos de $117 \%$ na produção de matéria seca, com o emprego de adubaçåo fosfatada. Subseqüentemente, MONTEIRO \& WERNER (1977) estudaram os efeitos de nitrogênio e fósforo na produ ção de capim-coloniạo, em vasos e no campo. 0 solo do tipo Podzólico Vermelho Amarelo variaçåo Laras recebeu doses de adubo correspondentes a $100,55,51$ e $21 \mathrm{~kg} / \mathrm{ha}$ de $\mathrm{N}, \mathrm{P}_{2} \mathrm{O}_{5}$, $K_{2} O$ e $S$, respectivamente, em experimento do tipo subtrativo. No estabelecimento do capim, o fósforo foi o elemento que isoladamente proporcionou maior resposta, aumentando a produçåo de $1,3 \mathrm{~g}$ de matéria seca por vaso, na testemunha nåo adubada, para $6,5 \mathrm{~g}$ por vaso, com a adiçăo de fósforo. Notável, entretanto, foi a resposta ao nitrogênio mais fósfo ro conjuntamente, cuja produçåo foi de $14,2 \mathrm{~g}$ de matéria seca por vaso. 
No Amazonas, em Itacotiara, ITALIANO et alii (1982b) realizaram um experimento de adubaçåo em pastagem de capim-coloniåo, em degradaçăo. 0 solo, do tipo LVA, texturaargilosa, tinha pH 4,9 e 3 ppm de fósforo. Aplicaram-se 100 $\mathrm{kg} / \mathrm{ha}$ de $P, 55 . \mathrm{kg} / \mathrm{ha}$ de $\mathrm{S}, 30 \mathrm{~kg} / \mathrm{ha}$ de $F T E$ e $1 \mathrm{t} / \mathrm{ha}$. de calcá rio em experimento do tipo subtraçăo. Os autores verificaram que apenas o fósforo contribui de modo significativo para reativar a produtividade dessa pastagem, nåo havendo resposta aos demais nutrientes estudados.

ITALIANO et alii (1982a), em experimento subse qüente, no mesmo local, aplicaram 25,50 e $75 \mathrm{~kg} / \mathrm{ha}$ de $\mathrm{P}_{2} \mathrm{O}_{5}$ a pastagem, confirmando o efeito do fósforo sobre a reativaçåo da produtividade da forrageira.

No Pará, AŻEVEDo e SOUZA (1982a) realizaram, em Altamira, um ensaio de adubaçăo em pastagem de capim-colo niăo, com 7 anos de idade. Foram aplicadas diversas combinações das seguintes doses de nutrientes: $100 \mathrm{~kg} / \mathrm{ha}=\mathrm{de}$ $\mathrm{P}_{2} \mathrm{O}_{5}, 100 \mathrm{~kg} / \mathrm{ha}$ de $\mathrm{K}_{2} \mathrm{O}, 75 \mathrm{~kg} / \mathrm{ha}$ de $\mathrm{N}, 58 \mathrm{~kg} / \mathrm{ha}$ de $\mathrm{S}, 1000$ $\mathrm{kg} / \mathrm{ha}$ de calcário e $30 \mathrm{~kg} / \mathrm{ha}$ de FTE. 0 tratamento em que se adicionou nitrogênio, fósforo e enxofre foi o que mais incre mentou a produção, aumentando-a em 53\% em relaçăo à testemunha nåo adubada. Nas mesmas condições, AZEVEDO e SOUZA (1982b) testaram o uso de $25,50,75,100$ e $150 \mathrm{~kg} / \mathrm{ha}$ de $\mathrm{P}_{2} \mathrm{O}_{5}$, verificando que a somatória da produçåo em cinco cortes foi $62 \%$ maior que a testemunha, quando se usaram 100 kg/ha de $\mathrm{P}_{2} \mathrm{O}_{5}$. O tratamento de maior produçåo, entretanto, foi aquele, em que se forneceram $75 \mathrm{~kg} / \mathrm{ha}$ de $\mathrm{P}_{2} \mathrm{O}_{5}, 30 \mathrm{~kg} / \mathrm{ha}$ de FTE e $50 \mathrm{~kg} / \mathrm{ha}$ de $\mathrm{S}$.

SANCHEZ (1982), trabalhando com um solo oxisol da Colômbia, com aproximadamente 1 ppm de P disponivel, ob- 
servoú diferenças entre as gramineas, nos niveis ótimos. de fertilização com P. O Andropoaon gayanus necessitou de 50 $\mathrm{kg} / \mathrm{ha} \mathrm{P}_{2} \mathrm{O}_{5}$ /ha para alcançar o máximo rendimento, enquanto

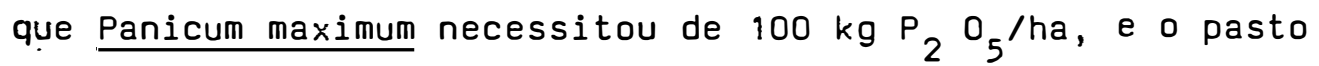
de jaraguá, (Hyparrhenia rufa) $200 \mathrm{~kg}$ ou mais.

\subsection{Fontes de Fósforo}

Na adubação de pastagens, o uso de diferentes fontes de fósforo tem adquirido grande importância, principalmente devido ao preço crescente dos produtos importados e à maior oferta de fosfatos naturais brasileiros.

WERNER et alii (1968) testaram nove fontes em duas doses, 75 e $150 \mathrm{~kg} / \mathrm{ha}$ de $\mathrm{P}_{2} \mathrm{O}_{5}$, em uma pästagem de pangola em Nova Odesșa. Os teores de $N$, Ca e $K$ no solo eram médios, o $\mathrm{P}$ se aproximava do teor médio e o pH.era de '. 5,86. Considerando-se os resultados de três anos, as maiores produções foram com o superfosfato triplo, escória de Thomas, superfosfato simples e fosfato de Alvorada: No segundo ano, os melhores resultados couberam à fosforita de olinda, super fosfato simples e farinha de ossos, enquanto que, no terceiro ano, se destacaram os fosfatos de rocha (fosforita de Olinda, fosfato de Araxá e fosfato de Alvorada). Os autores concluiram ser interessante o uso de uma mistura de fosfatos solúveis e fosfatos naturais para a adubação de pastagens.

SERRĀo et alii (1979) têm verificado que a deficiência de $P$ é o fator indutor do processo de degradação de pastagens de Panicum maximum, na Amazônia. A disponibilidade do fosfato é alta, imediatamente depois da queima da mata, mantém-se acima do nivel'critico, durante 4 anos, e lo 
go diminui. A correção desse problema. é extremamente simples e de baixo custo. Estes autores recomendam aplicar a lanço $50 \mathrm{~kg}$ de $\mathrm{P}_{2} \mathrm{O}_{5} / \mathrm{ha}$, a metade na forma de superfosfato simples e a outra metade como fosfato de rocha. Nessas condiçőes, a população de Panicum maximum aumentou de 25 a $90 \%$.

Com o objetivo de se estudar a resposta da Bra chiaria decumbens a doses e fontes de fósforo, na presença de três doses de calcário, SANZONOWICZ et alii (1987) estabe leceram um experimento em um Latossolo Vermelho-Escuro.Obse varam-se aumentos de produção de matéria seca até o nivel mais elevado de fósforo aplicado, sendo que os maiores acrés cimos foram obtidos entre os dois niveis mais baixos, 38 e $150 \mathrm{~kg} / \mathrm{ha}$ de $\mathrm{P}$. As produções obtidas com a dose de $38 \mathrm{~kg} / \mathrm{ha}$ de P, na forma de fosfato de Araxá, não diferiram daquelas obtidas na parcela que não recebeu adubação fosfatada. A calagem prejudicoú a produção de matéria seca, i.: no primeiro ano, nas parcelas que receberam fosfato de Araxá, desaparecendo esse efeito com o tempo. Em termos de produção total de matéria seca, o superfosfato simples e o termosfosfato magnesiano (Yoorin) mostraram melhor desempenho que o hiperfosfato, fosfato natural de Gafsa, Marrocos, e o fosfato na-. tural.de Carolina do Norte (EUA), sendo que as quatro fontes foram superiores ao fosfato natural de Araxá.

AZEVEDO e SOUZA (1982b), em Altamira-PA, apliearam 50. $\mathrm{kg} \mathrm{P}_{2} \mathrm{O}_{5}$ /ha a uma pastagem já estabelecida de capim -colonião (ㅁ. maximum). Empregaram, como fontes de fósforo, superfosfato simples, superfosfato triplo, hiperfosfato, fos fato de Araxá, termofosfato de Yoorin e misturas das duas fontes solúveis com cada um dos fosfatos naturais $(25 \mathrm{~kg}$ $\mathrm{P}_{2} \mathrm{O}_{5}$ /ha de cada fonte). Após cinco cortes, os autores veri- 
ficaram que: 1) a combinaçăo entre superfosfato triplo e ter mosfosfato de Yoorin foi o tratamento que proporcionou maior produção de matéria seca; 2) as duas fontes solúveis não diferiram entre si; 3 ) dentre os fosfatos naturais, o que proporcionou maior produção foi o hiperfosfato.

2.5. A acidez e a calagem em solos tropicais. A toxidez. de $A l$ e Mn e a disponibilidade de nutrientes no so10.

Nos solos tropicais thá uma prédominância de carga va riável, latóssolos e solós podzólicos são normalmente ácidos. A acidificação do solo pode ser visualizada como um pro cesso continuo, onde diversas fontes contribuem para 0 : mesmo: 1) hidrogênio resultante da hidrólise do $\mathrm{CO}_{2}$ produzido pela biomassa; 2) dissociação de hidrogênio dos radicais orgânicos; 3) hidrogênio resultante do metabolismo vegetal excretado diretamente na rizosfera. Quando a atividade de hidrogênio na solução torna-se suficientemente elevada $(\mathrm{pH}<$ 6), as argilas silicatadas são solubilizadas, e aluminio é liberado para a solução dos solos (COLEMAN \& THOMAS, 1967).

Os principais fatores relacionados com a acidez do solo, que afetam o desenvolvimento das plantas, são o pH e sua influência sobre o Al trocável, as bases trocáveis, - Mn solúvel e a disponibilidade de nutrientes. Ressalta-se, ainda, a importância da interação entre esses fatores, o que torna muito dificil separar seus efeitos isoladamente (JACKSON, 1963). 
o aluminio é o cátion predominantes nas condições de solo ácido (COLEMAN \& JACKSON, 1960, KAMPRATH, 1970, 1972; MALAVOLTA et alii, 1977 e COLEMAN \& THOMAS, 1967).

Em solução, o aluminio ocorre em forma hidrata da $\mathrm{Al}\left(\mathrm{H}_{2} \mathrm{O}\right)_{6}^{3+}$. Entretanto, a atração do Al pelo oxigênio de molécula de água é tão fortẹ, que tende a repelir o $\mathrm{H}^{+}$ou pró ton da molécula de água, aumentando a concentração de $\mathrm{H}^{+}$na solução (MELO, 1985). Esse processo é chamado de hidrólise, e ele é responsável por parte da acidez potencial, podendo ser assim esquematizado:

$$
\mathrm{Al}\left(\mathrm{H}_{2} \mathrm{O}\right)_{6}^{3+}=\mathrm{Al}(\mathrm{OH})\left(\mathrm{H}_{2} \mathrm{O}\right)_{5}{ }^{2+}+\mathrm{H+} .
$$

A hidrólise do aluminio passa então a ser a principal fonte de acidez do solo.

0 aluminio age no solo e na planta, sendo responsável. pela redução na disponibilidade, entre outros, de $P, \mathrm{Ca}$ e Mg (provavelmente por meio de redução de suas solubí lidades). Este fato é tão marcante que impossibilita separação nitida entre os efeitos das deficiências minerais e os da toxidez de aluminio (MUNNS, 1965).

De acordo com BLACK (1968), a toxidez de Al representa a combinação de alguns efeitos, dos quais a inibi ção do crescimento das raizes talvez seja o mais óbvio. Como resultado, a planta pode ser levada a sofrer deficiência múltipla de nutrientes. ANDREW (1978) descreve que o pH baixo reduz o Ca disponivel do solo e, também, reduz a aḅsorção de Ca pela raiz. 0 aumento do $A l$, posteriormente, restringe a absorção de cálcio, e as raizes tornam-se defịcientes no elemento, interações do.P com o Al ocorrem dentro e sobre as raizes, a nodulação é dificultada ou ausente, e as leguminosas tornam-se intensamente deficientes em $\mathrm{N}$. 
MALAVOLTA et alii (1977) também afirmam que as relações entre aluminio e fósforo têm sido muito estudadas, mas não foi estabelecida ainda explicação para o principal efeito observado (a precipitação do fósforo pelo aluminio) que resulta em produtos de baixa solubilidade no meio, na superficie da raiz, nos espaços intercelulares e nos tecidos condutores. Observam ainda que a interferência na absorção de cálcio e de magnésio parece ser um caso de inibição compe titiva, podendo até ser anulado pela elevação da concentração de cátions divalentes no meio.

0 efeito do $A 1$ sobre outros ions é pouco conhecido, havendo indicações dispérsas de que há redução na absorção de $\mathrm{K}, \mathrm{Mg}, \mathrm{NO}_{3}^{-}$, $\mathrm{Fe}, \mathrm{Mn}$ e $\mathrm{Zn}$ (PATTERSON, 1965) e $\mathrm{S}$ (JACKSON, 1963). O aumento do Al no subtrato reduz a absorção de P. e K. (MUNNS, 1965). O Al parece agir na superficie da raiz e dá célula, ficando adsorvido à sua parede, formando fosfatos e reduzindo. a permeabilidade da parede \&For \& BROWN, 1963). Seu efeito mais lesivo, entretanto, é a redução do ritmo de divisão celular na raiz (RORISON, 1958):

Com relação à tolerância à toxidez de Al, AN-

DREW (1978) relata que a produção de mätéria seca de $\underline{M}$. la-

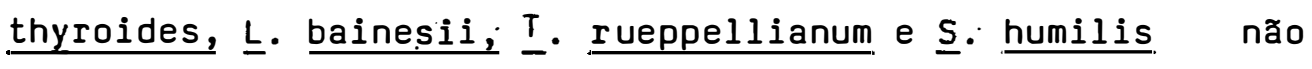
foi deprimida até 2,0 ppm de $A l$ na solução; as de $\underline{D}$. uncinatum e I. semipilosum foram deprimidas com $2,0 \mathrm{ppm}$, mas não

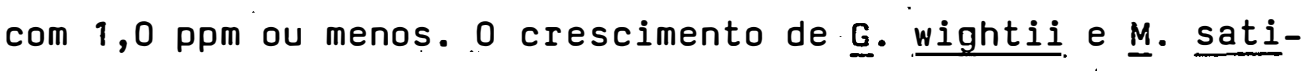
va, entretanto, foi severamente reduzido com 0,5 ppm de Al ṇa solução.

É largamente aceito que o $\mathrm{pH}$, por si :: : mesmo, não afeta diretamente o deserivolvimento vegetal, exceto em casos extremos (FOTH, 1978). Porém as condições resultantes 
de um $\mathrm{pH}$ mais baixo são limitantes ao desenvolvimento vegetal, tanto pelo efeito sobre a disponibilidade de nutrientes, como pela conservação de aluminio a niveis tóxicos para - vegetal.

LINDSAY (1972) mostra que a solubilidade de $B$, Cu, Fe, Mn e $2 n$ decresce com a elevação do.pH, sendo máxima, quando o $\mathrm{pH}$ esteve entre os valores de 4,0 e 5,0.

SIQUEIRA \& VELOSO (1978) verificiaram, estudando nove solos de cerrado, que a adsorção máxima de molibdato ocorria, em $\mathrm{pH} 4,0$, e diminuia, quando o $\mathrm{pH}$ se elevava, tornando-se minima a partir de 6,0 .

WERNER (1975), revendo a literatura sobre o uso de micronutrientes em pastagens, conclui que, para calagem em nivel baixo ou moderado, seria suficiente a aplicação de Mo, enquanto para niveis mais altos pode ser necessária a adição de $\mathrm{Fe}, \mathrm{Zn}, \mathrm{B}$ e $\mathrm{Cu}$.

Outra caracteristica associada à baixa fertili daide solos ácidos são os niveis tóxicos de $M n\left(M n^{2+}\right)$. MALAVOL TA et alii (1977) sumarizaram os principais efeitos do exces so de manganês nas culturas: menor atividade respiratória e fosforilação, redução na absorção de $\mathrm{Fe} e$ de $\mathrm{Mg}$, diminuição na sintese de clorofila e má formação dos cloroplastos, dificuldades na divisão celular, deficiência de auxina. Morfologicamente as plantas podem apresentar clorose internerval, encurtamento e deformação do limbo, manchas enegrecidas ao longo dos tecidos condutores, nas pontas e margens das folhas.

ANDREW (1978) relata que as diferenças entre espécies, em suas respostas ao excesso de Mn, têm sido evidentes desde muitas décadas, e que as leguminosas são, gera 
mente, mais sensiveis que as não leguminosas. Para algumas leguminosas tropicais, Andrew \& Hegarty citados por ANDREW (1978) encontraram a seguinte ordem relativa de tolerância à toxidez de Mn, comparada com a alfafa: Centrosema pubescens > Stylosanthes humilis $>$ Lotononis bainesii > Macropti. lium lathyroides $>$ Leucaena leucocephala > Desmodium uncina $\underline{\text { tum }>\text { Medicago sativa }}>>$ Glycine wightii. $>$ Macroptilium atro purpureum cv. Siratro.

Entre as gramineas forrageiras tropicais, também há diferença de tolerância ao Aḷ. Estudos realizados por SPAIN (1979), usando soluções nutritivas, evidenciaram que Brachiaria decumbens apresentou uma ligeira resposta positiva ao incremento de $0,5 \mathrm{ppm}$ de $A l$, em solução, sem manifestạ redução de crescimento sob altas concentrações desse ele mento na solução do solo. Panicum maximum mostrou uma forte tolerância à metade da concentraçăo de Al que tolera Brachia. ria decumbens. Ao contrário, o capim buffel Cenchrus ciliaris, uma graminea comum em regiões ústicias, porém não ácidas da Austrália, é seriamente afetado pelo Al. Essa excelen te forrageira está bem adaptada a solos não ácidos, porém, para desenvolver-se bem em rẹgióes de oxissóis e ultissóis, é necessário neutralizar completamente o Al trocável pela ca lagem.

\subsection{Calagem para Leguminosas Forrageiras e Efeitos na Fixação Biológica de Nitrogênio.}

Um dos temas bastante contraditório na proposi. ção de um programa de adubação para as leguminosas forrage ras é estabelecer o melhor nivel de calagem a ser empregado 
em solos ácidos, com o intuito de maximizar a fixação de nitrogênio e produção de forragem.

Após revisar muitos trabalhos realizados com leguminosas, ANDREW (1978) afirma que elas diferem em sua capacidade de nodular e de crescer, quando variam o $\mathrm{pH}$ e o nivel de Ca no solo.

SALINAS \& SANCHEZ (1976), revisando extensa li teratura sobre o potencial de espécies e variedades de leguminosas para produção, sob condições adversas de fertilidade, concluem que, entre as fórrageiras estudadas, se destacam como tolerantes a baixos niveis de $\mathrm{pH}$ : Stylosanthes humi lis, Centrosema pubescens, e, como exigentes em pH mais elevado, Glycine wightii e Medicago sativa. Lembram, ainda, a dificuldade de separar, no solo, os efeitos da toxidez de Al devidos à deficiência de $P$, o que transforma a seleção si multânea para tolerância a ambas as condições adversas em uma necessidade.

Estudando o efeito da calagem sobre o crescimento de Rhizobium, NORRIS (1959) demonstrou ser baixa exigência desses microorganismos em $\mathrm{Ca}$ e mais alto em $\mathrm{Mg}$. MUNNS (1970) relata que o Ca é particularmente importante por ocasião da infecção radicular das raizes pelas bactérias. Ele parece influir no. encurvamento dos pêlos radiculares, sem o qual elas não conseguem penetrar e formar o cordão de infecção em direção às células sub-epidérmicas, que formaråo, mais tarde, o nódulo.

ANDREW \& NORRIS (1961) realizaram trabalho em casa-de-vegetação com úm solo notavelmente deficiente em $\mathrm{Ca}$. Estudando a resposta de 5 leguminosas de clima tropical e 4 de clima temperado à aplicaçåo de cálcio $\left(\mathrm{CaCO}_{3}\right)$, conçuiram 
que as tropicais apresentaram maior capacidade em extrair. Ca do solo, pobre neste elemento, do que as temperadas. Embora em menor intensidade que as temperadas, as leguminosas tropi cais também responderam à aplicação de $\mathrm{CaCO}_{3}$, e ambos os gru pós parecem apresentar as melhores produções de matéria seca, em torno das mesmas quantidades de carbonato aplicadas. É interessante observar que nesse trabalho, as máximas concentrações (\%) e acumulação-de N (mg/vaso) ocorreram, geralmen te, em niveis de $\mathrm{CaCO}_{3}$ maiores do que aqueles que causaram aś máximas produções de forragem. Esse fató, também, foi men cionado por outros pesquisadores, tais como FRANÇA et alii (1973).e por VARGAS \& DOBEREINER (1974), que propõem a separação da nutrição parä o crescimento da planta e aquela para a simbiose leguminosa Rhizobium.

MUNNS \& FOX (1977a, 1977b), trabalhando

no Hawai, estudaram comparativamente as respostas à calagem apresentadas por 18 leguminosas tropicais e temperadas, em um experimento de campo, onde $\mathrm{CaCO}_{3}$ foi aplicado em um oxisol deficiente em nitrogênio, com problemas de excesso de Mn, baixa saturação em Ca, mas sem problemas de toxidez de Al. O corretivo foi aplicado em doses crescentes que proporcionaram variaçð̄es de $\mathrm{pH}$ na faixa de 4,7 a 7,1. As curvas de resposta à calagem nåo apresentaram, no geral, distintas diferenças entre as leguminosas de clima tropical e temperado. Entretanto dentro de cada grupo houve acentuadas diferenças entre espécies. Entre as tropicais, as mais responsivas foram: L. leucocephala, G. wightii, $M$. axillare e D. intortum. Entre as temperadas as menos responsivas foram: I: subterraneum, G. $\max e$ L. cornicultus. MUNNS \& FOX (1977a) acrescentam que a tendência relativa de diferentes espécies responde 
rem à calagem depende da relativa importáncia do $A 1, M n, \cdot p H$, Ca, Mo e outros fatores relacionados com o pH, em cada solo particular, e, também, devido ao comportamento de cada espécie e seu Rhizobium associado, em relação a cada um desses fatores.

\section{2:7. Respostas de Centrosema à Calagem}

ANDREW \& NORRIS (1961) cultivaram algumass legu minosas em casa-de-vegetação, usando um solo com pH de 5,5, sob oito niveis de calagem (de 0 a 2,5 t/ha de carbonato de cálcio), e observaram elevação da produção de matéria seca e do $N$ total na parte aérea de centrosema, até a dosé de 1,25 t/ha de calcário que elevou o $\mathrm{pH}$ a 6,4 .

JONES et alii -(1970) realizaram um experimento em casa-de-vegetação, visando ao estudo das aplicações de nu trientes minerais em algumas leguminosas tropicais, dentre elas a centrosema, estudando em condições de solos de campo cerrado; os $A A$ concluiram que a omissåo da calagem ( $\mathrm{Ca}+\mathrm{Mg})$ produziu reduções drásticas na produção de matéria seca, che gando a alcançar o indice de $46 \%$, quando comparado com a aḍu bação completa.

WERNER \& MATTOS (1972), cultivando a centrose ma num solo LVE-orto, sob 3 niveis de calagem, elevaram o pH para 6,4. A produção de matéria seca foi reduzida, enquanto que os teores de $\mathrm{N}$, Ca, P, Mo e Cu foram elevados. Os teores de $\mathrm{Zn}$ e o $\mathrm{N}$ total aumentaram até a calagem proposta .. para neutralização do Al trócável ( $\mathrm{pH} 5,8)$, decrescendo a partir desse nivel. SOARES \& VARGAS (1974), estudando, em condiçס̃es cie casa-de-vegetação, o efeito da calagem sobre três latoso- 
los sob cerrado, com pH e Al trocável de 5,2 e 0,9; 5,2 e 0,7 e 4,2 e 2,0, aplicaram respectivamente: 1,$8 ; 2,8$ e 6,0 t/ha de calcário e obtiveram aumento na produçåo de matéria seca da parte aérea, no peso seco das raizes e no teor de N na planta.

Trabalhos realizados por diversos autores evidenciaram que a calagem mostrou-se necessária a fixação de $N$ e produção de matéria seca, visto que sua ausência determi nou decrescimos significativos nos parâmetros considerados (DOBEREINER \& ARONOVICH, 1966; JONES : et alii, 1970 e COLOZZA et àlii, 1986).

-2.8. Respostas de Galactia à Calagem

MATTOS \& WERNER (1972) realizaram ensaio em vasos com a galactia num solo Podzólico Vermelho-Amarelo-variação Laras com pH inicial de 5,8. Verificaram que a omissăo de calagem não resultou em redução de matéria seca da le guminosa.

MONTEIRO (1980), cultivando a galactia num so10 Podzólico Vermelho-Amarelo-variação Laras Álico, mediante a aplicação de quatro niveis de calagem $(0 ; 0,83 ; 1,66$ e 2,49 t de calcário dolomitico por hectare), observou, no pri meiro corte, uma variação linear para a produção de matéria seca e para o nitrogênio total da parte aérea.

Trabalhando com uma Areia Quartzosa, coletada no cerrado de Brotas, $\left(\mathrm{pH}=4,8\right.$ e $\mathrm{Al}^{+++}$trocável $=0,8$ equivalentes miligrama por $100 \mathrm{ml}$ de solo), "COLOZZA et alii (1987) verificaram que a ausência de calagem provocou redução significativa na produçăo de matéria seca, peso de nódulos, teor de nitrogênio e quantidade total de nitrogênio. 


\subsection{Respostas de Soja perene à Calagem}

QUAGLIATO \& NUTI (1969) obtiveram aumento na produção de matéria seca, em ensaio de vasos feitos com dois solos de cerrados (um de Nova Odessa e outro de Pirassununga, SP), através da aplicação de calcário até o nivel de $1,4 \mathrm{t} / \mathrm{ha}$, com a qual foi atingido o $\mathrm{pH}$ de 5,2 , no primeiro solo, e o de 5,7, no segundo.

LOVADINI (1972), estudando a resposta à calagem, em 2 solos ácidos (com até 2 tha de calcário dolomitico num LVa e até 4,2 t/ha num LVe), observou acréscimo, tan to na produção de M.S., quanto na absorção de $\mathrm{N}, \mathrm{Ca}, \mathrm{Mg}$, entrè outros nutrientes.

FRANÇA et alii (1973), cultivando soja-perene cv. Tinaroo, em um Latossol vermelho-Escuro, i i.! encontraram efeito marcante de calagem ( $6 \mathrm{t} / \mathrm{ha}$ de $\mathrm{CaCO}_{3}$ ) no peso seco da planta e nos teores de $\mathrm{N}, \mathrm{P}$, Ca e Mg; quando o $\mathrm{pH}$ se elevou de 4,3 para 5,7 .

FRANÇA et alii (1973), cultivando um LVE fase cerrado, de Sete Lagoas, MG, observaram que a calagem elevou a produção de M.S., o N total e os teores de N, P, Ca e Mg, reduzindo o peso dos nódulos, quando não foi aplicado B. A adição de $\mathrm{Mg}$ não afetou qualquer variável estudada. Na presença de calagem, O B aumentou a produção de matéria seca, o $\mathrm{N}$ total e o peso dos nódulos, e reduziu os teores de N, P, Ca e Mg, na parte aérea. Na ausência de calagem, o Mo aumen tou o teor de $\mathrm{N}$ e o $\mathrm{N}$ total. Houve interaçåo calagem $\times \mathrm{Zn}$ pa ra produção de matéria seca e para os teores de $\mathrm{P}$ e de $K$.

ANDREW (1978), estudando o efejto do pH na nodulaçåo e na produção de leguminosas tropicais e subtropi- 
cais, encontrou efeito positivo e alto para soja-perene, que dobrou a produção de matéria seca, quandó a concentraçăo de Ca aumentou de $2 \mathrm{mM}$ com a elevação do $\mathrm{pH}$ de 4,0 para 5,0. MUNNS \& FOX (1977b), cultivando 18 leguminosas em um oxissolo havaiano, elevaram progressivamente $0 \cdot \mathrm{pH}$ de 4,7 a 7,1, com a aplicação de doses crescentes de calcário até $22^{\circ}$ t/ha, e observaram que, para a obtenção de $90 \%$ de pró duçåo máxima de matéria seca, a cv. Cooper exigiu 6 t/ha de calcário, enquanto para a cv. Tinaroo bastaram 5 t/ha para o $\therefore$ mesmo desempenho. Nesse mesmo experimento, MUNNS et FOX (1977a). realizaram a avaliaçåo. dos efeitos de calagem na nodulaçăo e fixaçăo de nitrogênio, observando que o número de nódulos nas duas variedades de soja-perene aumentava com a elevą̧ăo do $\mathrm{pH}$ até valores em torno de 6,0 , enquanto que o tamanho dos nódulos sofria acréscimos devido à calagem, até em pH ligeiramente superior a 6,0 para soja-perene Tinaroo e para a faixa de pH 5,0 a 5,5 para a soja-perene Cooper. $\mathrm{Na}$ variedade Tinaroo, a eficiência dos nódulos em fixar nitrogênio acompanhou a tendência do número deles, e, na Cooper, a fixaçăo de nitrogênio continuou sendo mais eficiente, embo ra o número de nódulos diminuisse em pH mais elevado. Concluindo, esses autores afirmam que o aumento no tamanho dos nódulos seria o maior responsável pelo aumento da produção de matéria seca na variedade de Tinaroo, como conseqüência de aplicação do calcário.

\subsection{Calagem para Graminea Forrageira.}

Os resultados disponiveis na literatura indicam que as gramineas tropicais năo respondem, ou respondem 
muito pouco, à calagem (LOTERo et alii, 1971; SPAIN et alii, 1975; CIAT, 1977 e SIQUEIRA et alii, 1980). 0 crescimento dessas gramineas tem sido mais limitado por deficiência de fósforo (EMBRAPA, 1976), ou de outros nutrientes, (SPAIN et alii, 1975) do que por toxidez de aluminio.

Um exemplo de adaptação das gramineas forrage $\underline{i}$ ras as condiçőes severas de acidez foi obtido em um oxisol da Colômbia, com pH de 4,5 e 95\% de saturação de Al - por SPAIN (1979). As gramineas Andropogon gayanus, Brachiaria de cumbens e Panicum maximum foram muito tolerantes, apresentan do um crescimento máximo aos niveis de 0 ou 0,5 toneladas de calcáriọ por hectare. A aplicação de $0,5 \mathrm{t}$ de calcário por hectare não modificou nem $0^{\prime} \mathrm{pH}$ de solo, nem a saturaçăo em aluminio, porém proporciónou $\mathrm{Ca}$ e $\mathrm{Mg}$ às plantäs. Trabalhos realizados no CIAT (1980) estimaram que a $\underline{\text { B. humidicola foi }}$ tolerante ao stress pelo Al (95\% de saturação de $A l$ ), enquan to que o Panicum maximum apresentou diminuição nos seus ren-· dimentos com a saturaçåo de Al de $82 \%$.

Aparentemente, as gramineas forrageiras respon dem unicamentè à fertilizaçăo com cálcio e/ou magnésio, quan tidades tais que são suficientes para elevar a produção de matéria seca, porém insuficientes para afetar o $\mathrm{pH}$ e o nivel de aluminio trocável do solo.

CARVALHO et alii (1984), baseando-se em dados da literatura, estimou a tolerância ou adaptaçăo relativa de algumas gramineas forrageiras à toxidez de aluminio: braquiá Iia $=$ andropogon $=$ capim-gordura $>$ coloniăo $=$ jaraguá $=$ capim -elefante. 
2.11. Calagem Baseada na Eleváção do fndicè da Saturação. em Bases.

Vários autores têm demonstrado que existe uma relação entre o pH e a saturação em bases dos solos (CATANI \& GALLO, 1965 ; COMISSÃO DE SOLOS, 1960; RAIJ et alii, 1968; CAMARGO \& RAIJ, 1975 e QUAGGIO; 1983).

RAIJ (1981) verificou que a relação estreita, entre o pH do solo e sua saturação em bases, pode ser represeñtada pela fórmula: $\mathrm{pH}=4,50+0,025 \mathrm{~V}$, onde $\mathrm{V}$ expressa a saturação em bases do solo. A uma saturaçẳo de $40 \%$, corres1 pondem valores de $\mathrm{pH} 5,5$ e a uma saturação de $60 \%$, um $\mathrm{pH}$ de 6,0 .

Outra correilação bastante importänte em trabalhos de pesquisa, principalmente na seleçăo de cultivares e/ou espécies tolerantes ao Al, é a existente entre a satura ção de Al e pH (RAIJ, 1981). A medida que o pH aumenta pela neutralização da acidez do solo com a calagem, o Al trocável diminui, minimizando-se em valores de $\mathrm{pH}$, em torno de 5,5. Confrontando as duas correlaçōes, nota-se que, com a saturação em $A 1$, só se opera em menos da metade da C.T.C. do solo, o que limita a utilização da correlação $A l \times \mathrm{pH}$, na prática da calagem, quando se tem interesse na faixa correspondente a valores de $\mathrm{pH}$ acima de 5,5. Então, o autor adota a metodologia de recomendação da calagem pelo critério da elevação da saturação em bases. É necessário determinar para cada espécie, e/ou variedade, a porcentagem de saturação em bases (V): mais adequadas, visto haver diferenças entre espécies ou mesmo entre variedades dentro de uma mesma espécie. WERNER (1984), empregando os resultados experimentais disponiveis, 
enquadrou as leguminosas soja-perene e leucena, como exigentes à elevação do indice de saturação em bases a 60\%, enquanto que a galáxia, centrosema e o capim-colonião, como exigentes à elevação do indice de saturação em bases a $40 \%$. É- evidente que essa generalização apresenta limitações, podendo ocorrer oscilações para os diferentes so los e plantas, principalmente para as variedades forrageiras recém-lançadas pela pesquisa. Nesses casos, são recómendados trabalhos experimentais que permitam classificar melhor essas novas variedades, adequanido-as a um nivel ótimo de calagem.

\subsection{Molibdênio}

0 molibdênio participa ativamente como componente de pelo menos três diferentes enzimas que catalizam dí versas e não relacionadas reações necessárias ao metabolismo das plantas. Essas três enzimas são: nitrato redutase, nitró genase e sulfato oxidase (NICHOLAS, 1975).

A disponibilidade de molibdênio no solo depende de diversos fatores, tais como: material de origem e grau de intemperismo da rocha matriz, nivel de acidez e concentra ções de óxidos de ferro, aluminio e manganês, que afetam sua concentração na solução de solo. A concentração de molibdênio na planta está diretamente relacionada com a intensidade de ocorrência na solução do solo, uma vez que o fluxo de massa se constitui no principal mecanismo de fornecimento de Mo às plantas.

A determinação, se os niveis de molibdênio nos solos são suficientes ou não para atender às necessidades 
das plantas, deve ponderar os seguintes aspectos: no solo as quantidades presentes são extremamente baixas, há influência das caracteristicas quimicas dos solos (KABATA-PENDIAS \& PENDIAS 1984), a importância da reserva das sementes (GURLEY \& GIDDENS, 1969), que podem mascarar uma deficiência no solo. No geral, os solos apresentam niveis suficientes desse elemento, poirém, em certas condições, aparecem deficiências que se caracterizam por clorose generalizada, principalmente em leguminosas, que lembra os sintomas caracteristicos de deficiência de nitrogênio. É dificil observar-se sintomas visuais de toxidez de Mo nas plantas, mesmo quando absorvido em quantidades excessivas. O consumo de forragem com concentrações elevadas de Mo pode provocar molibdenose, que é representada por uma metabolização deficiente de cobre pelos animais, especialmente os rum-inantes.

2.13. Ocorrência da Deficiência e Respostas ao Molibdênio

As primeiras descobertas de deficiência de Mo, em forrageiras, foram encontradas em trevo (Trifolium subter raneum L.), no nordeste da Austrália, por ANDERSON (1956a), ANDERSON \& ARNOTT (1953), MCLACHLAN (1955) e SWAIN (1959), onde a introdução dessa leguminosa falhava completamente em decorrência da deficiência desse elemento.

Em leguminosas forrageiras tropicais, a sojaperene foi a pioneira com relação à resposta à aplicação de Mo, quando cultivada num solo latossólico da Austrália, em 1961 (LUCK \& DOUGLAS, 1966). Posteriores descrições de resposta ao molibdênio, com leguminosas forrageiras tropicais, em experimentos ao nivel de campo, foram obtidas por LUCK \& 
DOUGLAS (1966), TRUONG et alii (1967), OSTROWSKI (1970), e MEARS \& BARKUS (1970). Freqüentemente têm sido descritas res postas ao Mo, em leguminosas forrageiras, em estudos de vasos (MANNETJE et alii, 1963; SHAW et alii, 1966; ROE \& JONES, 1956; MEARS \& BinKUS, 1970 ; HALL, 1970; KERRIDGE et alii, 1972; WERNER \& MATTOS,. 1974; DE-POLLI et alii, 1976; EMBRAPA, 1980; PAULINO et alii, 1985; COUTO et alii, 1982 e MONTEIRO et alii, 1987).

JOHANSEN et alii (1977), obtiveram respostas diferenciais ao molibdênio aplicado entre as espécies de leguminosas: As leguminosas mais responsivas foram Glycine wightii cv. Tinaroo, Desmodium intortum cv. greenleaf, segui das pelo Macroptilium atropurpureum cv. Siratro e Medicago. sativa cv. Hunter River, e sendo menos responsivas o Lotononis e Stylosanthes.

2.14. Molibdênio na Planta

45

As principais funções do Mo nas plantas eståo relacionadas com o transporte de elétrons durante as reaçoes bioquimicas. De fato, as enzimas nitrato redutase e nitrogenase requerem Mo na redução do. $\mathrm{NO}_{3}^{-}$e na fixação de $\mathrm{N}_{2}$, res pectivamente.

A nitrogenase é uma enzima adaptativa presente em microorganismos procariontes capazes de fixar o $\mathrm{N}_{2}$, sendo formada por dois componentes distintos que se combinam para reduzir o $\mathrm{N}_{2}$ a amônia. O componente I é uma proteina que con tém ferro e molibdênio e um peso molecular em torno de 180.000, enquanto que o componente II apresenta um peso molecular de 50.000 e contém apenas o ferro como cofator. Rela- 
ções adequadas entre os dois componentes e entre molibdênio e ferro na molécula são necessárias, para que haja um perfei to funcionamento de enzima, além de outros fatores que influenciam sua atividade (GUPTA \& LIPSETT, 1981). Desse modo, a deficiência de Mo irá proporcionar uma redução na sintese da enzima, refletindo-se numa menor atividade e, conseqüentemente, numa redução da fixação biológica de $\mathrm{N}_{2}$.

Mais Mo é necessário para fixação simbiótica de $\mathrm{N}_{2}$ que para o metabolismo geral da planta ' $: .$. (ANDERSON, 1956a). O sistema simbiótico de maior interesse agropecuário é constituido pela associação radicular, entre bactérias do gênero Rhizobium ou Bradyrhizobium com as leguminosas, que desenvolvem nódulos caracteristicos. Trabalhando com duas estirpes de Bradyrhizobium japonicum (nova denominação do Rhizobium japonicum), PEDROSA et alii (1970) levantaram a possibilidade de estarem associados à concentração da nitrogenase nos nódulos de soja e à eficiência nodular de đs duas estirpes; observaram, também, que, o teor de Mo, nos nódulos ocupados pela estirpe, com excepcional eficiência, foi duas vezes maior que os ocupados pela estirpe normal. Leguminosas eficientemente noduladas apresentam concentrações de Mo nos nódulos que chegam a ser dez vezes superiores às encontradas nas folhas. Em condições de deficiência, o Mo tende a acumular-se nos nódulos em detrimento das outras partes da planta (PATE, 1977), e-uma deficiência deMo pode ser induzida com sintomas visuais indistinguiveis da deficiência de $N$. Os nódulos das plantas deficientes em Mo são freqüentemente brancos ou verdes, quando comparados aos de cor rósea ou avermelhada, em plantas não deficientes. Usualmente, formamse muitos nódulos pequenos na planta deficiente, porém, na 
planta normal, aparecem nódulos maiores (ANDERSON, 1956b, MANNETJE et alii, 1963 e MEARS \& BARKUS, 1970).

Como o molibdênio apresenta uma mobilidade média no floema, os sintomas de carência, em geral, aparecem nas folhas velhas ou de média idade fisiológica, progredindo para a planta toda: clorose, que lembra a falta de $\mathrm{N}$, e atro fiamento da planta e mosqueado amarelo-esverdeado internerval, seguidos por manchas necróticas no ápice e margem das folhas, apresentando os bordos enrolados (MENGEL \& KIRBY, 1978).

Os mais importantes mecanismos

(processos)

dẹ. absorção de Mo pelas plantas, crescendo em solo, são a intercepção radicular e o fluxo de massa (BARBER et alii, 1963). As plantas parecem absorver o Mo na forma do ânion Mo $0_{4}^{2-}$ (CHESNIN, 1972). Os experimentos realizados por KANNAN \& RAMANI (1978) mostraram que este ânion é móvel. Quándo ele foi fornecido às folhas primárias do feijão, (Phaseolus vulgaris, L) muito dele foi transportado para o caule e raizes. TIFFIN (1972) também sugere que o Mo possivelmente seria transportado como ion molibdato ou complexado com compostos orgânicos, possivelmente aminoácidos sulfurados, açúcares ou outros compostos polihidroxilados.

A deficiência. de Mo resultá em reduções nos conteúdos de clorofila nas folhas:(AGARWALA et alii, 1978), conduzindo uma diminuição na eficiência fotossintética. A menor sintese de clorofila é um efeito secundário muito comum do distúrbio no metabolismo de $N$, desde que o. Mo não desempenha um papel direto na sintese de clorofila. 
2.15. Conteúdos de Molibdêriio.

As concentrações de Mo na parte aérea têm sido descritas em soja-perene (i.UCK \& DOUGLAS, 1966; MEARS \& BARKUS, 1970), siratro (OSTROWSKI et alii, 1978) e algumas espécies de Stylosanthes (JONES, 1974). Geralmente, as concentrações são inferiores a 1 ppm, embora, costumeiramente, con centrações menores que 0,5 ppm de Mo sejam obṣervadas. As concentrações de Mo, em plantas deficientes, estão freqüente mente abaixo de 0,1 ppm, com marcantes diferenças na concentração nas diversas partes da planta.

As concentrações de Mo na planta podem ser aumentadas além dos niveis mínimos requeridos pelas plantas através de práticas que aumentam o nivel de molibdênio dispo nivel no solo. Nenhuma injúria em muitas plantas é notada, mesmo onde a concentração de Mo excede 100 ppm, entretanto o uso excessivo de fertilizantes molibdenizados pode resultar interferências no metabolismo do cobre nos animais. Além do uso de fertilizantes molibdenizados, a aplicação de calcário em solos ácidos é um método freqüentemente efetivo, para aumentar a disponibilidade ao molibdênio no solo e à concentra. ção do Mo nas plantas. (ALLAWAY, 1968).

As concentrações de Mo na parte aérea das legu minosas mostram-se como um diagnóstico útil. Isto, porque a importante função do Mo está na fixação de $\mathrm{N}$ nos nódulos, de modo que a planta deficiente tem seu crescimento limitado - por um suprimento restrito de $\mathrm{N}$.

2.16. Mo nas Sementes e nos Nódulos

O Mo concentra-se nas sementes das leguminosas. As sementes podem armazenar e, posteriormente, colocar à disposição da planta quantidades de Mo bem superiores às 
que ela necessitará para completar seu ciclo

vegetativo (MEAGHER et alii, 1952). Nem todas as espécies são capazes de armazenar quantidades suficientes, na semente, para dar atendimento às necessidades da planta.

VINOGRADOVA (1943) obteve uma concentração média de Mo em 41 análises de sementes de leguminosas de 5,5 ppm de Mo. A concentração de Mo na semente dependerá das con dições de crescimento da planta. MEAGHER et alii (1952) demostraram a ocorrência de deficiência de Mo, em plantas cres cendo de sementes produzidas em solução nutritiva deficiente em Mo, que continham 0,05 a 0,1 ppm de Mo, enquanto que a de ficiência de Mo nem sempre poderia ser demonstrada em plantas oriundas de sementes produzidas comercialmente, que continham 0,5 a 5 ppm de Mo.

HARRIS et alii (1965) constataram resposta à aplicação de Mo em progênies (primeira geração), oriundas de sementes de soja colhidas em diversos estados norte-americanos, contendo menos de 2,6 ppm de Mo, enquanto progênies com 22,4 ppm Mo, oriundas de sementes colhidas no Texas, não res ponderam à aplicação de Mo.

GURLEY \& GIDDENS (1969) verificaram que teores elevados de Mo, na semente, supriram as necessidades de Mo na soja, na primeira geração, aumentando o rendimento de grãos, em solos deficientes em.Mo. Em um solo, as sementes com 48,4 ppm de Mo propiciaram maior rendimento de grãos do que as sementes com 19,0 ppm Mo, enquanto que, em outro, elas tiveram o mesmo comportamento. Houve pequena transferên cia ao Mo da semente original para a segunda geração, mas o efeito das aplicaçס̄es de Mo, no teor do nutriente nas sementes, deixou de existir, na terceira geração. 
Os mesmos autores constataram, também, que a obtenção de sementes, com alto teor de Mo, não foi possivel com a elevação da disponibilidade do Mo do solo pela calagem, mas o foi com a aplicação de elevadas doses de Mo nas sementes ( $560 \mathrm{~g}$ Mo/ha) e/ou por via foliar (1.122g Mo/ha). Verificaram, ainda, que a maior concentração de Mo na semente encontrava-se nos cotilédones (53\%), seguidos do embrião $(34,6 \%)$ e do tegumento $(12,4 \%)$.

O tratamento de sementes de soja, contendo bai xo teor de Mo, com doses crescentes de nutrientes, tendo como fonte o molibdato de amônio p. a. $(54,3 \%$ Mo), permitiu ajustar, aos teores de Mo encontrados posteriormente nas sementes, a equação: $\hat{y}=1,13+2,2421$ Mo, com $r^{2}=0,845$, atra vés da qual se estimou que a aplicação de g Mo/10 kg elevou o teor nas sementes para $21,3 \mathrm{ppm}$ Mo, e a aplicação de $18 \mathrm{~g}$ Mo elevou esse teor para 41,5 ppm Mo (SANTOS et alii, 1986), pró ximos aos valores encontrados por GURLEY \& GIDDENS (1969), como capazes de suprir as necessidades da soja cultivada em condições de carência média ou acentuada.

A análise da semente não tem sido usada na rotina, como um diagnóstico auxiliar para a detecção de deficiência de molibdênio, pois há uma grande variação no tamanho das sementes das leguminosas. BRUCE (1978), verificou que as sementes de soja-perene, produzidas em áreas deficientes em Mo, continham 0,06 ppm Mo, enquanto que sementes, produzidas em áreas não deficientes, continham 1,5 ppm Mo.

Os nódulos apresentam concentraçõès mais eleva das de Mo que as raízes ou parte aérea (JENSEN \& BETTY, 1943). 
JENSEN (1948) sugeriu que os nódulos poderiam conter

uma certa concentração de Mo, para a máxima eficiência de fixação, e propôs de 4 a 8 ppm de Mo para o trevo subterrâneo, e de 10 a 25 ppm de Mo para a alfafa. Quando os conteúdos de Mo nos nódulos de alfafa cairam abaixo de 3 a 10 ppm, houve restrições na fixação simbiótica de nitrogênio. Essa é uma concentração mais alta que a necessária para outras plantas. Para as leguminosas forrageiras tropicais não há informações sobre as concentrações ótimas de molibdênio nos nódulos..

2.17. Molibdênio no Solo

De acordo com DAVIES (1956), as formas de ocór rência de Mo no solo são: não disponivel, retido no interior da rede cristalina de minerais primários e secundários; condicionalmente disponivel ou trocável, retido nas argilas como Mo ${ }_{4}^{2-}$; e disponivel (variável com o $\mathrm{pH}$ e com nivel de $P$ assimilável), na matéria orgânica e solúvel em água. A parte disponivel para as plantas inclui o Mo na solução do solo (teores extremamente baixos), o.Mo adsorvido (trocável) à superficie de sesquióxidos (especialmente $\mathrm{Fe}_{2} \mathrm{O}_{3}$ e $\mathrm{Al}_{2} \mathrm{O}_{3}$ ) e de compostos cristalinos de baixa solubilidade e, também, 0 Mo complexado com a matéria órgânica (Van RAIJ.' et alii, 1987). .

A literatura internacional refere-se ao ânion $\mathrm{MoO}_{4}^{2-}$ como predominante nos solos e o mais importante para a nutrição de plantas.

HOROWITZ (1978), trabalhando com onze solos da zona Litoral - Mata do Estado de Pernambuco, determinou que o ion $\mathrm{MoO}_{4}^{2-}$ tem amplo campo de estabilidade entire pH 6,01 e 14, enquanto que o ion $\mathrm{HMoO}_{4}^{-}$é estável em condições oxidantes e pH menor que 6,01. Com pH mais ácido, e em condições aeróbicas, espera-se a predominância do ion $\mathrm{MoO}_{2}^{+}$. 
Os teores médios de Mo total nos solos brasileiros variam de 0,06 a 5,74, e as teores de Mo solúvel, em solução ácida de oxalato de amônio, estiveram entre 0,01 a 0,16 (BATAGLIA et ali1, 1976; DANTAS \& HOROWITZ, 1976 e HOROWITZ, 1978). Os solos com maiores teores de Mo foram aqueles derivados de rochas básicas, de materiais aluviais e coluviais e de sedimentos modernos, enquanto os mais pobres fo ram derivados de arenito de Bauru e de sedimentos modernos arenosos.

Outro fator relevante, que afeta a disponibili dade do molibdênio, é o pH do solo. A prática da calagem, elevando o pH do solo, aumenta a disponibilidade do Mo já presente no solo, podendo corrigir parcialmente ou completamente a deficiência desse elemento.

A calagem eleva a disponibilidade do Mo, libe-. rando-o dos minerais do solo, principalmente dos óxidos de ferro e de aluminio e de outros minerais de argila. As reações de 1 ịberação, em função do pH, foram propostas por REISENAUER et alii (1962); por exemplo:

$$
\mathrm{Fe}_{2}\left(\mathrm{MOO}_{4}\right)_{3}+6 \mathrm{OH}^{-} \longleftrightarrow 2 \mathrm{Fe}(\mathrm{OH})_{3}+3 \mathrm{MOO}_{4}^{2-}
$$

Os efeitos óbvios do $\mathrm{pH}$ na reação acima são: para formação de $\mathrm{Fe}(\mathrm{MoO})$, em $\mathrm{pH}$ baixo, e para a forma solúvel $\mathrm{MoO}_{4}^{2-}$ em $\mathrm{pH}^{2}$ alto.

\section{2.:18. Adubação com Molibdênio}

No Brasil são poucos os estudos detaihados de adubação de pastagens com Mo, sendo mais comum aqueles que se utilizam da técnica da presença ou ausência do nutriente. 
0 molibdênio pode ser aplicado às pastagens por vários métodos, em diferentes formas de fertilizantes. Nas fontes mais comumente usadas, Mo está presente na forma de $\mathrm{Mo}^{6+}$ como ion $\mathrm{MoO}_{4}^{2-}$ no $\mathrm{Na}_{2} \mathrm{MOO}_{4} \cdot 2 \mathrm{HO}_{2}$ e ( $\left.\mathrm{NH}_{4}\right)_{2} \mathrm{MOO}_{4} \cdot$ Outras fontes de Mo usadas são o trióxido de molibdênio $\left(\mathrm{MoO}_{3}\right)$, ácido molibdico $\left(\mathrm{H}_{2} \mathrm{MoO}\right)$, molibdenito (MoS ) e molibdênio de fritas, contendo $2^{4}$ a $3 \%$ de Mo (MURPHY ${ }^{2}$ WALSH, 1972).

A aplicação de fertilizantes inorgânicos frequentemente envolve a adição de micronutrientès, presentes nesses materiais como impurezas. SENESI è POLEMIO,

1. avaliando os teores de Mo total na uréia e no superfosfato, entre outros fertilizantes, obtiveram valores de 2 ppm e 15 ppm, respectivamente. Esses autores concluiram que essas impurezas de micronutrientes poderiam não somente ser consideradas uma possivel fonte potencial de contaminação do solo e de - toxidez a planta, podendo os prejuizos atingir a saúde dos animais que se alimentam dessas plantas, e o homem. Outro fator que deve ser considerado é que apenas a fração solúvel e disponivel afeta a nutrição da planta, e não as quantidades totais. Muitos outros fatores, tais como a composição quimica, propriedades físicas do solo, as condições climáticas e a tolerância das plantas devem ser consideradas na avaliação dos efeitos da adição de micronutrientes, contidos nos fertilizantes. Não há:reco mendação dos conteúdos máximos de micronutrientes em fertilizantes, para prevenir a contaminação no solo e a toxidez da planta.

O Mo pode ser aplicado por vários métodos: em tratamento na sementẹ aplicação no solo, ou em pulve- 
rização foliar.

A adição de molibdêniocum pélete das sementes tem trazido resultados algumas vezes benéficos ao desenvolvimento das plantas. KERRIDGE et alii (1973) não obtiveram diferenças significativas na produção de matéria seca das leguminosas forrageiras soja-perene, siratro e desmódio, me diante a aplicação de molibdênio ( $M O O$ ) no solo ou em como pélete. Por outro lado a adição de molibdênio ( ${ }^{3}$ MoO ) na peletização de sementes de siratro resultou em efeitos altamente benéficos na produção de matéria seca, na porcentagem de nitrogênio e no nitrogênio total da leguminosa, e' proporcionou reduçãă no teor de fósforo na planta (MONTEIRO et alii, 19802 .

A aplicação de Mo junto com o calcário na peletização de sementes representa um caminho prático de aplí cação do Mo, colocando-o na proximidade das sementés e sem prejuizos aos rizóbios do inoculante (DATE \& HILLIER, 1968).

WERNER (1986) recomenda na formação de pastagens consorciadas à aplicação ao solo de 70 a $100 \mathrm{~g}$ de $\mathrm{Mo}$ ha, nos casos em que o pH original do solo está acima de 6,0 , e de 110 a $150 \mathrm{~g}$ de Mo/ha; nos casos em que os valores de $\mathrm{pH}$ do solo estão abaixo de 6,0 , nas formas de molibdato de sódio ou de amônio.

- Mo também tem sido aplicado nas pastagens australianas em combinação com superfosfato, o chamado superfosfato molibdenizado. As quantidades de Mo empregadas variam de acordo com a granulometria e composição do produto e dependem da quantidade de superfosfato aplicada (LIPSETT \& DAYID, 1977).

A aplicação foliar de Mo favorece a absorção 
râpida e translocação na planta, suplantando a deficiência de Mo (MEAGHER et alii, 1952).

Na UFSM, foi conduzido um estudo em dois anos agrícolas, para avaliàr os modos de aplicação de Mo na cultura da soja (a lanço, sulco, foliar e na semente), bem como efeitos de dosagens (SANTOS et alii, 1986).' Esses autores concluiram que todos os modos de aplicação foram. superiores à testemunha, porém não recomendaram a aplicação a lanço, :pela dificuldade de sua distribuição uniforme; verificaram, também, que as demais formas de aplicação se mostraram agronomicamente viáveis.

\subsection{Cobalto}

O cobalto é um elemento essencial aos fixadores de $\mathrm{N}_{2}$, mediante a participação na composiçăo da vitamina $B$ e da coenzima cobamida, também conhecida como DA cobalamina ( 5 - desoxiadenosilcobalamina). A cobamita funciona como ativadora das enzimas metilmalonilmutase e redutase do nucleotideo (envolvida na reduçåo dos ribonucleotideos e desoxiribonucleotideos), que catalizam reações bioquimicas em culturas de bactérias fixadoras de $\mathrm{N}_{2}$, entre as quais 0 Rhizobium, O Bradyrhizobium e.seus bacteróides presentes nos nódulos das leguminosas (MENGEL \& KIRKBY, 1982).

O cobalto é um componente da vitamina ${ }_{12}$, quelado a quatro átomos de $\mathrm{N}$, no centro do anel corrin, que lembra o núcleo das porfirinas representado por quatro anéis pirólicos. No corrin, dois pirroles estão unidos diretamente entre si, ao invés de uma ponte metênica, como ocorre na porfirina (LEHININGER, 1970). A vitamina B associa-se com o 
nucleotideo 5 - desoxiadenosil, para formar a coenzima coba mida. Foi demonstrado que esta coenzima participa, juntamente com a enzima metilmalonilmutase, na isomerização do metil malonilcoenzima $A$ à sucinilcoenzima $A$. Pela ação da enzima suciniltioquinase, o sucinilcoenzima $A$ pode ser convertido a sucinato e ser metabolizado via ciclo de Krebs. Esta via meta bólica pode ser importante à fixação do $N$, uma vez que o oxoglutarato é continuamente retirado do ciclo de Krebs para sintese do:glutamato. Outra via metabólica é representada pe la reação com a glicina para formar o ácido aminolevúlico $(A L A)$, precursor do grupo heme da leghemoglobina (EVANS \& RUSSEL, 1971).

Na ausência de $\mathrm{Co}$, a sintese de sucinilcoenzima A é bloqueada, uma vez que falta a cobamida, pois a metil malonilmutase é inativa. Portanto a sintese da leghemoglobina será inibida e, conseqüentemente, ocọrerá uma diminuição na fixação de $\mathrm{N}_{2}$ (MENGEL \& KIRKBY, 1982).

KLIEWER \& EVANS, 1963, demonstraram efeitos nocivos da ausência de Co sobre o crescimento e acúmulo de $\mathrm{N}$ e cobamina, em cultura de Rhizobium meliloti._ Esses autores também demonstraram uma ampla variação no conteúdo de cobamida, em espécies de Rhizobium e Bradyrhizobium,mas pouca variação entre estirpes efiçientes de uma mesma espécie, ao passo que a concentração foi.bem menor nas ineficientes e parasiticas.

Um outro papel do Co no Rhizobium está na ativaçã̃o do sistema redutạse do nucleotideo. Em condições de deficiência de Co as células de Rhizobium mostram um desenvolvimento anormal alongado, e os sintomas sugerem uma lesão no processo de divisão celular. Co parece ser necessário,pa- 
ra que suficente coenzima $B$ seja sintetizada para possibi12

litar um funcionamento normal do sistema redutase do nucleotideo (EVANS \& RUSSEL, 1971).

\subsection{Cobalto na Planta.}

Não está totalmente esclarecido, se co é essencial para plantas superiores, embora haja algumas evidências sobre os efeitos favoráveis do Co, no crescimento das plantas, REISENAUER et alii (1963) e MENGEL \& KIRKBY (1982): Nas leguminosas o Co afeta a habilidade da planta em fixar ó $\mathrm{N}_{2}$ atmosférico, faz parte das coenzimas cobamidas, que estão envolvidades na migração dos átomos de hidrogênio, durante a formação de compostos amoniacais pelos rizóbios. A deficiên cia de Co inibe a formação.da leghemoglobina, e, portanto,

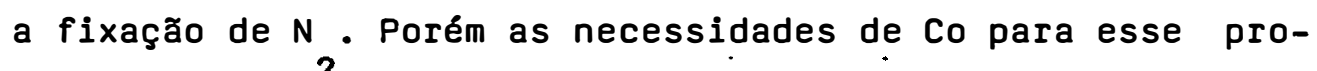
cesso são baixas. WILSON \& REISENAUER (1967) encontraram que 10 ppb de Co na solução nutritiva foram adequados para o crescimento da alfafa. Essa concentração representa uma rela ção de aproximadamente $1 / 300$ entre Co e Mo, necessária à nutrição das plantas. Apesar dessa relação matemática, não existem interaçסes entre dois nutrientes, conforme observaçōes feitas por GLADSTONES et alii (1977):

\subsection{Conteúdos nas plantas e Respostas ao Cobalto}

forma de $\mathrm{Co}^{2+}$ presente na solução do solo, e suprido, via fluxo de massa (KABATA \& BEESON, 1961), o que causa acumulação nas margens e pontas das folhas. Os baixos conteúdos de 
Co na soluçăo do solo refletem-se nos baixos

conteưdos nas plantas: 0,02 a 0,5 ppm.

JARDIM et alii (1962) encontraram, na regiăo do Pantanal de Mato Grosso e regiăo de Barretos, pastagens deficientes em cobalto, com teores variando de 0,02 a 0,04 ppm e 0,04 a 0,08 ppm, respectivamente, enquanto que, no Vale do Paraiba, as pastagens se encontram no limiar de carência, que é. de 0,05 ppm a 0,10 ppm.

Para JARDIM et alii (1966), o limite minimo de cobalto na matéria seca deve ser de 0,07 ppm, para atender às necessidades dos ruminantes.

PEREIRA et alii (1971), em estudos realizados com amostras de solos e plantas forrageiras, colhịidas em três fazendas distintas, e.em duas épocas do ano (dezembro e maio), provenientes do municipio de Téófilo Otoni, em Minas Gerais, concluiram que duas das três fazendas mostraram-se deficien-. tes em cobalto ( 2,5 ppm nos solos e 0,07 ppm nas plantas), e na outra fazenda $53 \%$ das amostras mostraram-se moderadamente deficientes, com teores de 2,5-5,0 ppm nos solos, e apenas 10\% das amostras de plantas forrageiras apresentaram teores deficientes de cobalto para nutriçăo animal.

Há algumas plantas, como Crotalaria cobaltico $\underline{l a}$, que podem chegar a acumular valores de 500 ppm de (MENGEL \& KIRKBY, 1982). As leguminosas apresentam concentraçōes de Co superiores às gramineas. Os conteúdos médios de Co, em alfafa, em diferentes paises, foram descritos na faixa de 0,10 a 0,57 ppm na matéria seca, enquanto que estes valores para os capins foram de 0,03 a 0,27 ppm (KABATA PEN DIAS \& PENDIAS, 1984). GALLO et alii (1974), estudando a composiçåo quimica de forragens tropicais, coletadas no Estado de såo paulo, encontraram, em média, para o capim-colo- 
nião, 0,06 ppm de Co, e, para as leguminosas šoja-perene .e centrosema, 0,25 e 0,11 ppm de Co, respectivamente.

Plantas bem noduladas, fixando ativamente 0 $\mathrm{N}_{2}$, apresentam boa concentração de cobamida e leghemoglobina noś nódulos; poṛém são ausentes, em nódulos deficientes em cobalto (KLEWIER \& EVANS, 1963). Se o solo é deficiente em Co, ocorre uma maior concentração nos nódulos, em comparação com as outras partes da planta (PATE, 1977).

A constatação da presença de complexos orgânicos de pequena cadeia com Co indicam sua incorporação no metabolismo da planta. Assim, FRIES (1962) identificou a vita- mina $B_{12}$ em ervilha, trigo e tremoço, em experimento conduzi do .em condições assépticas, portanto sem a presença de microorganismos capazes de sintetizar a vitamina è colocá-la à disposição das plantas.

\subsection{Cobalto no Solo}

$\mathrm{Na}$ solução do solo as concentrações de Co são relativamente baixas, oscilando entre 0,3 a $87 \mathrm{ppm}$, com a mais alta frequência entre 3 a 15 ppm (KABATA-PENDIAS \& PENDIAS, 1984). As rochas ácidas apresentam teo res de Co normalmente inferiores a $10 \mathrm{ppm}$ (MENGEL \& KIRKBY, 1982).

No solo, o cobalto solúvel em ácido acético normalmente corresponde ao Co prontamente disponivel, varian do de 0,02 a. 2 ppm (KABATA-PENDIAS \& PENDIAS, 1984 , sendo que os valores inferiores a 0,1 ppm podem ocasionar deficiên cias de Co às plantas (MCKENZIE, 1975).

Em solos da Unidade Utinga, derivada dé rochas 
ácidas, em Pernambuco e Alagoas, trabalho realizado por DANTAS (1971) evidenciou a presença de baixas concentrações de Co. O cobalto total (extraivel com ácido fluoridrico) foi in ferior a 2 ppm, enquanto que o solúvel (extraível com acetato de amônio $0,5 \mathrm{~N}$ ) foi a 0,1.ppm. Valores inferiores a 0,2 ppm já haviam sido apresentados como insuficientes, para dar atendimento às necessidades de Co as pastagens (HOROWITZ \& DANTAS, 1966). LOPES (1984) relata em diversos solos"em Såo Paulo, - concentrações de Co solúvel (extraivel com áci do acético $2,5 \%)$, situando-se entre 0,01 e 1,07 ppm. Os menores valores foram observados em solos originários de sedimentos àrenosos, e os maiores valores em solos originários de sedimentos modernos e de rochas básicas.

\subsection{Fatores que Afetam a-Disponibilidade do Cobalto.}

A disponibilidade do Co às plantas é regulada pela sua associação com óxidos de manganês, aluminio e ferro. Na natureza, o Co ocorre em dois estados de : oxidação, $\mathrm{Co}^{2+} \mathrm{e} \mathrm{Co}^{3+}$, sendo também possivel a formação do ânion com-

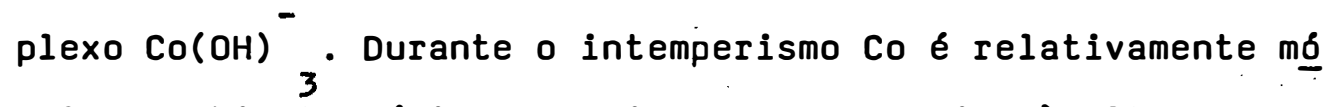
vel em ambientes ácidos e oxidados, mas devido à alta adsorção por óxidos de Fe e Mn, bem como pelos minerais de argila, esse elemento não migra nà fase solúvel. A disponibilidade de Co pode ser comprometida devido a sua adsorção pelos óxidos de $\mathrm{Mn}$, que aumenta grandemente com o pH, e a reação parece ser rápida (McKENZIE, 1975). Assim, TAYLOR \& MCKENZIE (1966) constataram que, em média, 79\% do Co total encontrava -se associado aos minerais, contendo óxidos de Mn.

A matéria orgânica do solo e o conteúdo de ar- 
glla támbém são importantes fatores que goverñam a distribul çăo e o comportamento do Co. A mobilidade do Co está fortemente relacionada ao tipo de matéria orgânica nos solos. Os quelatos orgânicos de Co são conhecidos por serem facilmente móveis e translocados nos solos. Embora solos ricos en matéIla orgânica sejam conhecidos tanto por um baixo conteúdo de Co e baixa disponibilidade: ' de Có, os quelatos orgânicos de Co também podem ser prontamente disponiveis: às plantạs (BLOOMFIELD, 1981), especialmente em pH mais elevados e em solos livremente drenados.

Trabalhos realizados por pesquisadores russos

têm demonstrado que, aumentando os conteúdos de húmus do so$10, \cdots$ de 3,4 para $16,9 \%$, houve reduçð̋es nos conteúdos de cobal to, em ervilha e aveia (TISDALE \& NELSON, 197.5).

Elevaçőes do pH-do solo diminuem a disponibili dade do cobalto. MITCHELL (1962), na Inglaterra, estudando os efeitos da calagem sobre os conteúdos de Co, observou para o trevo branco que os conteúdos de Co baixaram de 0,22 ppm (sem calagem) $\mathrm{pH} 5,4$ paria o valor de 0,12 ppm (com a aplicação: de $24 \% 2$ t. $\left.\operatorname{CaC}_{3} \mathrm{ha}\right) \mathrm{pH} 6,4$, e para o Rye grass os conteúdos iniciais baixaram de 0,35 ppm de Co (sem calagem). pH 5,4 para 0,12 ppm de Co (com aplicação de 24,2 $t$ Caco / ha:

3

0 papel dos minerais de argila montmorilonita e ilita tem sido significativo devido a sua grande capacidade de adsorção e relativa facilidade de liberação do Co. As ordens de adsorção do cobalto foram muscovita>hematita> ben tonita = caolinita (MCKENZIE, 1975).

Os fatores contribuintes à deficiência de Co para animais, em pastejo, são principalmente associados a so 
los alcalinos, solos pouco intemperizados e solos com altos conteúdos de matéria orgânica.

\subsection{Fertilização com Cobalto}

De um modo geral, o cobalto não é adicionado aos fertilizantes durante a adubação das pastagens. Entretan to, quando os valores são menores que $0,1 \mathrm{ppm}$ Co, na 'forragem, a deficiência pode ser suspeitada. A deficiência pode sei controlada pelo fornecimento de uma solução de cobalto ao solo, em quantidades de 1 ou $2 \mathrm{~kg} / \mathrm{ha}$, porém, se 0 solo contém grandes quantidades de minerais orgânicos, capazes de imobilizar o cobalto, qüantidades mais altas são requeridas (MCKENZIE, 1975).

A aplicação ao solo de Co, como sulfato e quelato EDTA, é uma prática muito comum para controlar a deficiência de Co nos ruminantes (KABATA-PENDIAS \& PENDIAS, 1984). Em trabalhos realizados no sul da Austrália, foram observados aumentos significativos nas produções de matéria seca e teờ de nitrogênio,em trevo subterrâneo, cultivado em condições de campo, mediante a aplicação de sulfato de cobalto $0,6 \mathrm{~g} / \mathrm{ha}$. JUNQUEIRA NETTO et alii (1977), . trabalhando com feijăo, em Paula Cândias (MG), observaram aumentos na produção de sementes, de palha e na altura das plantas, mediante a aplicação de cobalto na forma de cloreto de cobalto, na dosagem de $0,25 \mathrm{~g} / \mathrm{ha}$, aplicado em solução nas sementes.

De forma semelhante a que ocorre com o molibdênio, a aplicação de fertilizantes inorgânicos, como fontes de $N, P$ e $K$, frequentemente, envolve a adição de pequenas 
quantidades de cobalto presente como impurezas das -matérias primas utilizadas para fabricação desses produtos. SENESI \& POLEMIO (1981), estudando o conteúdo de micronutrientes inor gânicos, obtiveram valores de 1,4 ppm e de 16 ppm cobalto pa ra a uréia e para o superfosfato simples, respectivamente.

Adições de $C o$, em solução nutritiva purificada, resultaram em aumento de rendimento de matéria seca na ordem de 52\%, em soja inoculada com B. japonicum. Plantas sem cobalto apresentaram sintomas tipicos de deficiência de $\mathrm{N}$ e tiveram menos $\mathrm{N}$ total que as plantas supridas com Co (AHMED \& EVANS, 1960). Além da resposta altamente positiva às concentrações de 0,1 e 1,0 ppb Co, análises de tecido da parte aérea demonstraram que a porcentagem de $\mathrm{N}$ e o conteúdo de clorofila, em plantas deficientes, foram sensivelmente re duzidos.

No Ceará, TOKARNIA (1981), através de análises de figados de bovinos, concluiram que uma doença, co nhecida como "mal do fastio", caracterizada por perda de ape tite, fezes endurecidas e, finalmente, a morte, era causada por deficiência de cobalto na alimentação.

De acordo com CARVALHO et alii (1976), os efei tos da deficiência de cobalto receberam numerosas denominações, e, no Brasil, ficou conhecido como "mal do fastio".

Para evitar o risco de deficiências sub-clinicas, parece que o nivel minimo de cobalto na dieta de carnei ro deveria ser de 0,06 a $0,07 \mu \mathrm{g} / \mathrm{g}$ ou ppm (UNDERWOOD, 1966). Para o gado, MAC PHERSON et alii (1973) encontraram que niveis de 0,049 $\mathrm{\mu g} \mathrm{Co} / \mathrm{g}$ na dieta resultaram em redução no cres cimento. Gado, pastejando em Panicum maximum e Stylosanthes. guianensis, mostrou aumentos no ganho de peso vivo, quando foram suplementados com cápsulas de cobalto intra-ruminal. 
Respostas a cobalto terapia têm sido observadas, na costa de Queensland, na Austrália. Animais, pastejan do em Panicum Maximum, contendo $0,018 \mu \mathrm{Co} / \mathrm{g}$, e em Macroptilium, Centrosema e Stylosanthes, com 0,050 $\mu \mathrm{g}$ Co/g, respon deram positivamente à suplementação de Co (GARTNER et alii, 1980). 
3. MATERIAL E MÉTODOS

$\because 3.1 .1 \cdot$ Local

Os experimentos foram conduzidos em condições de casa-de-vegetação, em duas-etapas: a primeira, sendo realizada junto à Seção de Nutrição de Plantas Forrageiras do Instituto de Zootecnia, em Nova Odessa, Estado de São Paulo, e a segunda etapa, no Centro de Energia Nuclear na Agricultu ra, em Piracicaba, SP.

3.2. Espécies Estudadas

3.2.1. Leguminosas

Foram estudadas 3 (três) espécies de leguminosas forrageiras tropicais, a saber:

Neonotonia wightii (Wightii e Arn) Lakey var. Tinaroo - soja-perene Tinaroo

Centrosema pubescens Benth - centrosema

Galactia striata (Jacq.) Urb. - Galáxia

3.2.2. Graminea

A graminea estudada foi o capim-colonião (Pani. cum maximum Jacq. cv. IZ-1). 
$3: 3 \cdot$ Solos

No experimento com as leguminosas foram utili$?$

zados os dois tipos de solos: A- Latossolo Vermelho-Amarelo distrófico e B- Latossolo Vermelho-Escuro-Alico, enquanto que, no experimento com a graminea, somente se empregou 0 Latossolo Vermelho-Amarelo distrófico. Os solos foram coletados a uma profundidade de $0-30$ centimetros, secos à sombra, e passados em peneira com $3 \mathrm{~mm}$ de malha. As amosttas dos solos coletados foram analisadas quimicamente, revelando as caracteristicas fisicas e quimicas apresentadas na Tabela 1.

3.4. Procedimento Experimental e Condições de Cultivo

Foram utilizados vasos de cerâmica com as pare des internas pintadas com tinta impermeabilizante e revestidas internamente com sacos plásticos, com capacidade de cinco quilos de solo, para o cultivo das leguminosas, ou com ca pacidade de três quilos e meio, no cultivo da graminea.

A calagem foi efetuada em 28.10 .85 (para as le guminosas) e 08.08.86 (para a graminea).

As quantidades de calcário empregadas foram de terminadas, de acordo com o critério de elevação do indice. de saturação em bases do solo (RAIJ, 1981).

0 ponto inicial para a calagem foi o nivel zero de calcário. No experimento com as leguminosas, adotou-se um nivel intermediário correspondente a doses de calcário, visando à elevação do indice de saturação, em bases dos solos a 35\%, e um nível máximo para elevação do indice de satú ração, em bases a 70\%. No experimento com o capim-colonião, 1

OLIVEIRA, J. B. (Instituto Agronômico de Campinas, Campinas) Comunicação pessoal, 1985. 


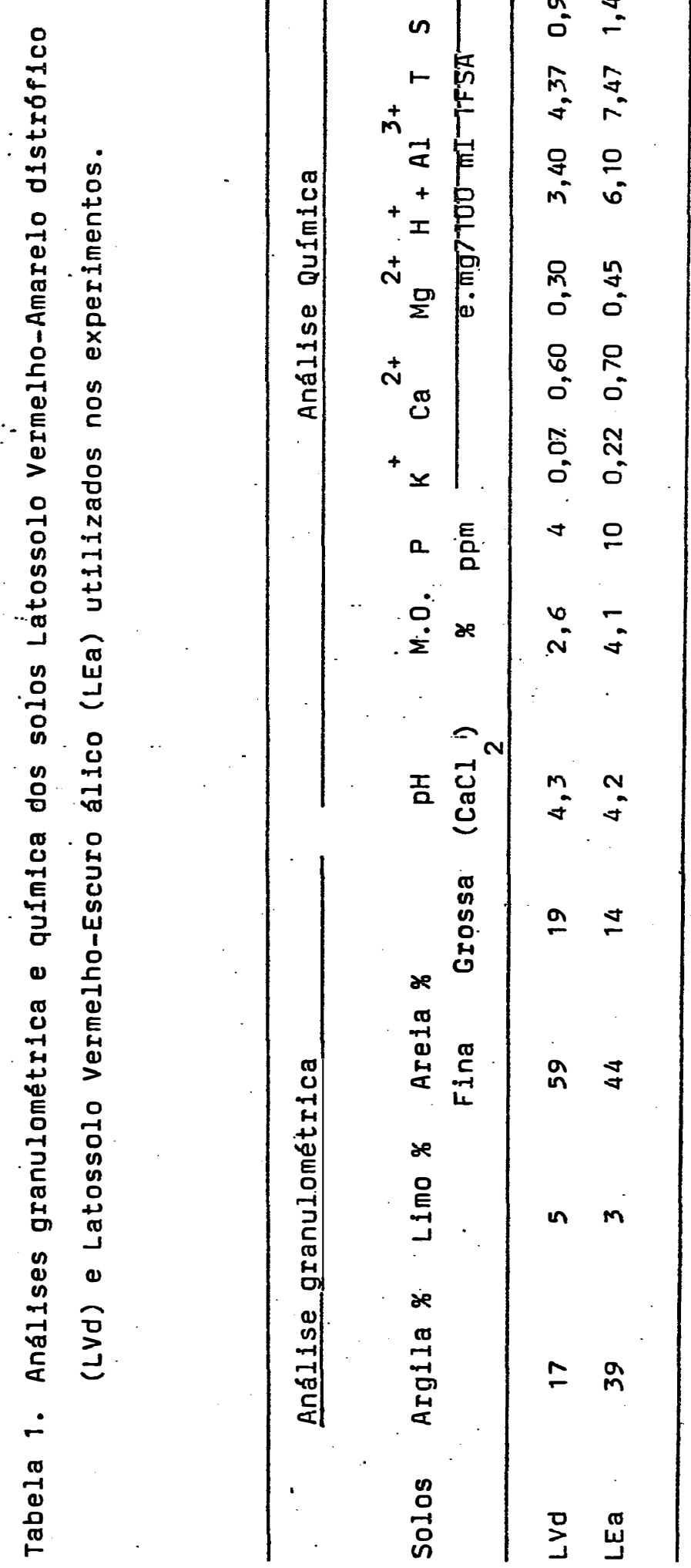


ou não se aplicou calcário ou foi aplicado para elevação do Indice de saturação, em bases a 70\%. As quantidades de corre tivo aplicadas nos dois solos são mostradas na Tabela 2.

0 calcário aplicado foi um calcário calcinado com PRNT (Poder Relativo de Neutralização Total) de 130\%, contendo $44 \%$ de $\mathrm{CaO}$ e $20 \%$ de $\mathrm{MgO}$.

Após a mistura do corretivo com o solo, procedeu-se uma agitação manual, durante 5 minutos, para completa homogeneização, e aplicou-se $800 \mathrm{ml}$ de água destilada e deió nizada, elevando a umidade do solo até próximo à capacidade de campo, emambos os solos. A seguir, os solos foram mantidos cobertos com papel manilha dentro dos vasos, nas condiçōes de casa-de-vegetação, deixando-se reagir en repouso até a época do plantio.

Em.27.11.85, foí realizada a semeadura das leguminosas forrageiras. As sementes, antes de serem colocadas nos vasos, foram escarificadas mecanicamente com lixa e distribuidas em sulcos de 1 a 2 centimetros de profundidade, co locando-se 50 sementes de soja-perene var. Tinaroo, 40 semen tes de centrosema e 30 sementes de galáxia. o capim-colonião cultivar IZ-1 foi semeado nos vasos (50 sementes por vaso), em 09.09 .86 .

Decorrido um periodo de aproximadamente 15 dias, foram realizados desbastes periódicos, deixando-se cin co plantas por vaso, tanto para as leguminosas como para o capim-colonião. Nessa ocasião, as plântulas de leguminosas foram inoculadas com $1 \mathrm{ml}$ por planta de uma suspensão de células de Rhizobium, com aproximadamente $10^{8}$ bactérias por $\mathrm{ml}$. As estirpes de Rhizobium especificas foram selecionadas pelo Instituto Agronômico de Campinas (IAC), à saber:SMS-164 para 


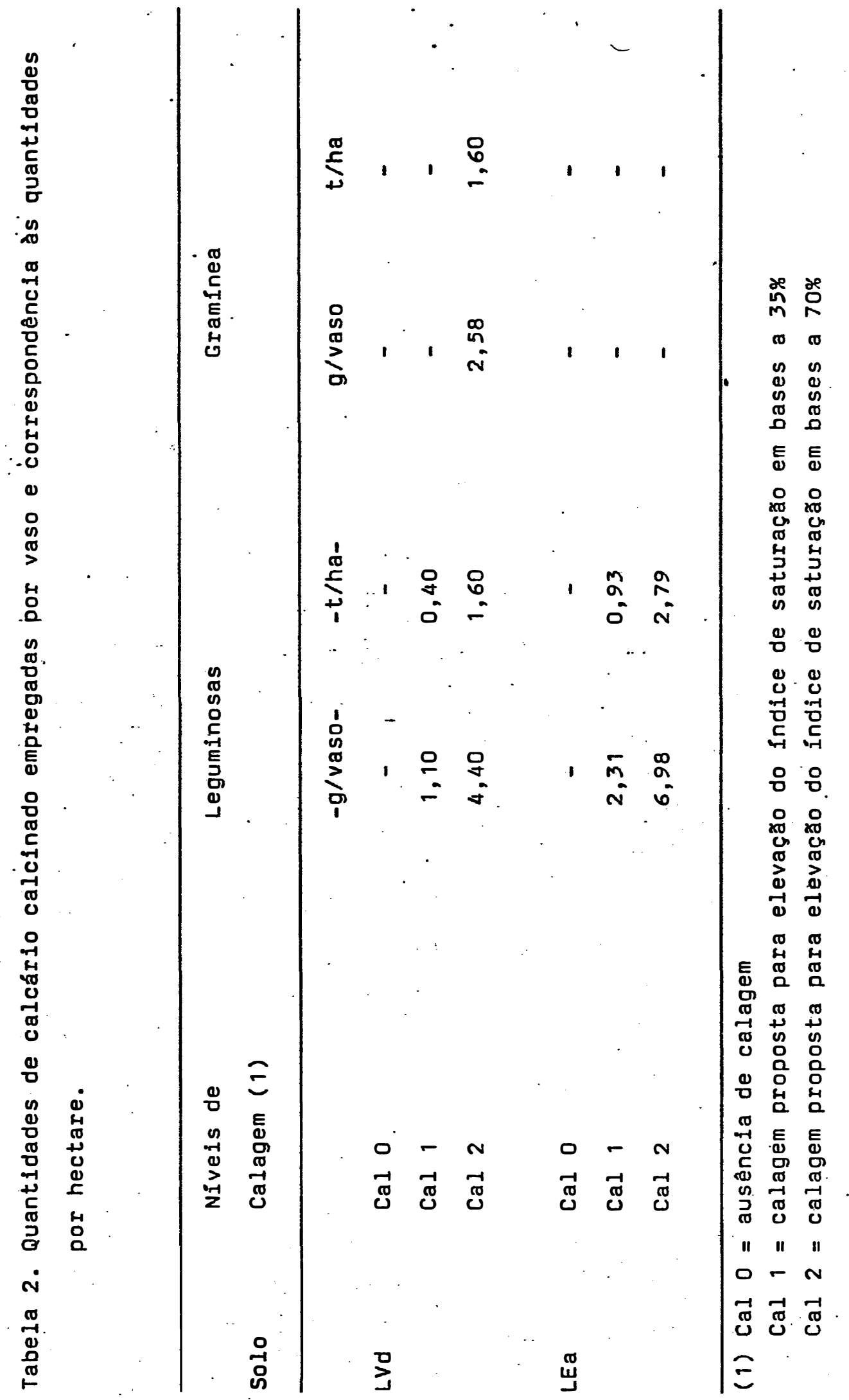


centrosema, SMS-138 e SMS-300 para a galáxia e SMS-128 SMS-117 para soja-perene.

No experimento com as leguminosas, os nutrientes, fósforo, potássio, enxofre, e os micronutrientes, boro, cobre, ferro e zinco, foram aplicados na época da semeadura, na forma de solução nutritiva. As quantidades e fontes dos elementos são apresentadas na Ṫabela 3 .

$\mathrm{Na}$ Tabela 4 são mostradas as quantidadés e fon tes de nutrientes empregadas na forma de solução nutritiva, no experimento com capim-colonião.

Após a semeadura, durante todo o periodo de cultivo das forrageiras, os vasos foram irrigados duas vezes por̈ dia com água destilada e deionizada.

Tendo em vista o lento crescimento inicial das leguminosas, em 17.12.85, foi-feita uma aplicação de $0,025 \mathrm{~g}$ de $N / v a s o(5 \mathrm{ppm}$ de $N$ ). A fonte de nitrogênio foi a uréia p.a., diluida em água destilada e deionizada, na proporção de. 8,04g de uréia em 151 de água e com aplicação de 100ml de solução por vaso.

\subsubsection{Delineamento Experimental}

Os experimentos foram conduzidos, usando um de lineamento experimental de blocos ao acaso, em arranjo fatorial, com quatro repetições pàra cada uma das espécies em se parado. Nos ensaios com as leguminosas forrageiras, os fatores que compuseram os tratamentos foram cobalto (presença e ausência), molibdênio (presença e ausência) e calagem (ausên cia de calagem - Cal 0, calagem proposta para elevação do ín dice de saturação, em bases de 35\% - Cal 1, e calagem propos ta para elevação do indice de saturação, em bases de $70 \%$ Cai 2). 


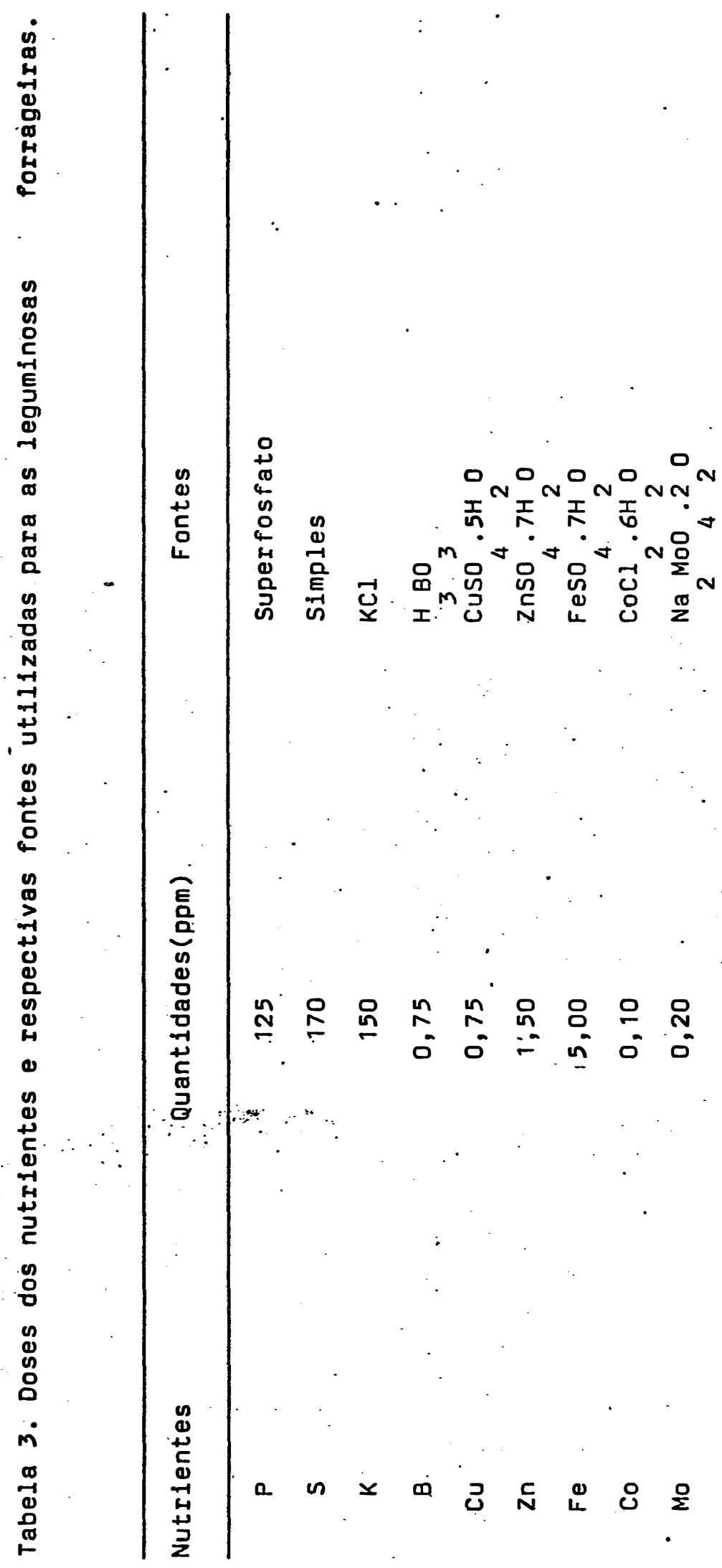




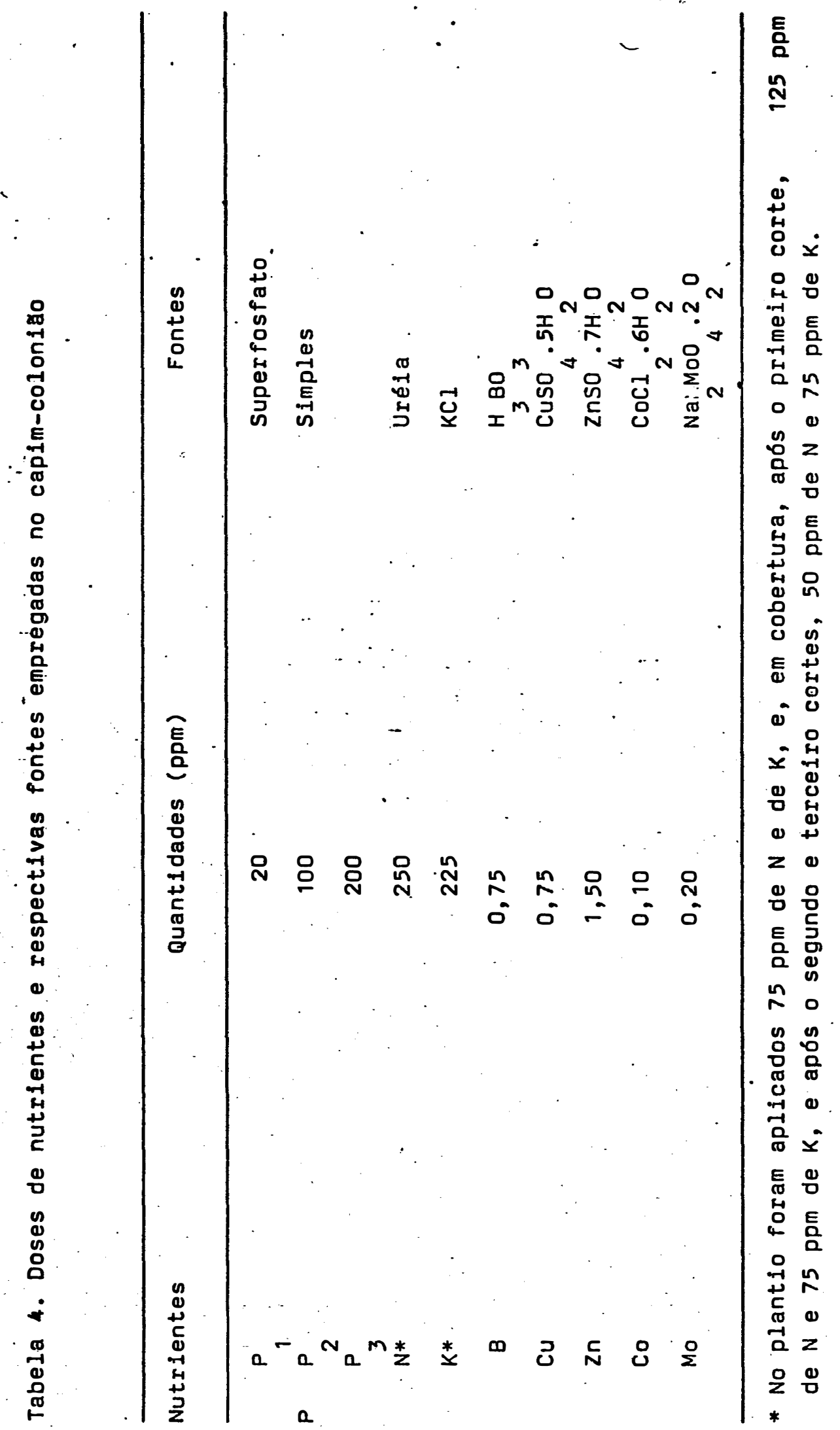


Os tratamentos empregados foram os seguintes:

1. Calagem 0 - cal 0

2. Cal $\mathbf{0}+$ cobalto

3. Cal 0 + molibdênio

4. Cal 0 + cobalto + molibdênio

5. Calagem 1 - cal 1

6. Cal $1+$ cobalto

7. Cal 1 + molibdênio

8. Cal 1 + cobalto + molibdênio

9. Calagem 2 - cal 2

10. Cal 2 + cobalto

11. Cal·2 + molibdênio

12:- Cal 2 + cobalto + molibdênio

No experimento com capim-coloniäo cV. IZ-1, os fatores estudados foram: calagem (ausência e presença), micro nutrientes (ausência e presença) e fósforo $\left(P_{1}=20 ; P_{2}=100\right.$ e $P=200 \mathrm{ppm}$ ).

os tratamentos empregados foram os seguintes:

1. NP K

2. NP ${ }^{1} \mathrm{~K}$ calagem

3. NP ${ }^{1} K$

4. ${ }^{2} \mathrm{~K}$ calagem

5. $N P^{2} K$

3

6. NP $K$ calagem

7. $N P^{3} K$ micronutrientes

8. NP ${ }^{1} \mathrm{~K}$ calagem, micronutrientes

9. NP $\mathrm{K}$ micronutrientes

10. NP ${ }^{2} k$ calagem, micronutrientes

11. $N P^{2} K$ micronutrientes

12. $\mathrm{NP}_{3}^{3} \mathrm{~K}$ calagem, micronutrientes 


\subsection{Colneitas}

As leguminosas sofreram dois cortes,

enquanto que o capim-coloniăo recebeu quatro cortes.

Em 07.01.86, aos 40 dias após o plantio, foi rea lizado o primeiró corte das leguminosas cultivadas no solo Latossolo Vermelho-Amarelo distrófico, e, aos 14.01 .86 (quarenta e sete dias após o plantio), foi realizado o primeiro corte das leguminosas cultivadas no solo Latossolo Vermelho-Escuro âlico.

O segundo e último cortes das leguminosas foram realizados conforme datas apresentados na Tabela 5 .

Tabela 5. Datas de corte para as diferentes leguminosas

\begin{tabular}{lccc}
\hline \multicolumn{1}{c}{ Leguminosas } & & Solo & Data \\
\hline Soja-perene cv. Tinaroo & - & LVd & 06.02 .86 \\
Soja-perene cv. Tinaroo & & LEa & 13.02 .86 \\
Centrósema & & LVd & 17.02 .86 \\
Centrosema & & LEa & 19.02 .86 \\
Galáxia & & LVd & 18.02 .86 \\
Galáxia & & LEa & 20.02 .86 \\
\hline
\end{tabular}

As plantas foram seccionadas rente ao solo, usan do uma tesoura de poda para efetuar o corte. A parte aérea co letada foi colocada em sacos de papel, devidamente etiquetados e levados em estufas de circulação forçada de ar, para secagem a $65^{\circ} \mathrm{C}$, durante 48 horas, com posterior pesagem para determinação da produção por vaso.

Após o corte final de cada espécie, as raízes fo ram separadas do solo, através de jatos de água corrente. A seguir, procedeu-se a remoção, purificação dos nódulos e sua contagem. As raizes foram lavadas com água destilada e deionizada. 
O material colhido (das raizes e nóduḷos) também sofreu secagem a $65^{\circ} \mathrm{C}$, em estufa de circulação forçada de ar, durante 48 horas, e foram pesados separadamente.

O material da parte aérea e das raizes de cada vaso foi finamente moido, em separado, em moinho tipo Whiley, e acondicionado em frascos de vidro fechados com tam pa plástica.

Para o capim-colonião foram realizados 'quatro cortes, em 20.01 .86 (42 dias de idade), 13.01 .86 (rebrota com 24 dias), 11.12 .86 (rebrota com 28 dias de idade), e em 13.01 .87 (rebrota com 33 dias de idade), seguindo-se a mesma metodologia descrita para as leguminosas. 0 material verde da parte aérea e das räizes foi colocado em estufa de circulação forçada de ar, à temperatura de $65^{\circ} \mathrm{C}$, durante 48 horas. Após a secagem, foị pesado em balança dé precisão, para determinação da produção de matéria seca. A moagem e o acondicionamento das amostras foram semelhantes às executadas e já descritas no experimento com as leguminosas forrageiras:

\section{7. Análises Laboratoriais}

As determinações dos teores de nutrientes foram realizadas no laboratório da Seção de Nutrição de Plantas Forrageiras do Instituto de Zootecnia, Nova Odessa - SP, com exceção dos micronutrientes cobalto e molibdênio, que fó ram determinados no laboratório da Seção de Nutrição Mineral de Plantas do Centro de Energia Nuclear na Agricultura, Pira cicaba - SP. 


\subsubsection{Determinação dos teores de Nitrogênio}

0 método adotado para determinação do teor de $\mathrm{N}$ foi o de Micro Kjedhal. Foram utilizados $100 \mathrm{mg}$ de material seco e moido para cada amostra, adicionando-se $5 \mathrm{ml}$ de mistura digestora (contendo a seguinte proporção por litro: 175ml de água destilada, $18 \mathrm{~g}$ de $\mathrm{Na}$ sè $.5 \mathrm{H} 0,4,0 \mathrm{~g}$ de CuSO .5H 0 , $21,94 \mathrm{~g}$ de $\mathrm{Na} S \mathrm{SO} .10 \mathrm{H}$ o e $200 \mathrm{ml} \mathrm{H}^{2} \mathrm{SO}^{2}$ concentrado). A amônia foi destilada, em meio alcalino, recebido em solução de ácido bórico a 2\%, com a mistura dos indicadores bromocresolverde e vermelho de metila, sendo titulada com uma solução padronizada $\mathrm{H}_{2}$ SO

3.7.2. Determinação dos teores de $\mathrm{P}, \mathrm{K}, \mathrm{Ca}, \mathrm{Mg}, \mathrm{S}, \mathrm{B}, \mathrm{Fe}, \mathrm{Cu}$, Mn, Zn, Mo e Co

A digestão da matéria seca foi realizada pelo método "Nitrico-Perclórico", utilizando-se 1,0g de amostra, $8 \mathrm{ml}$ de HNO $65 \%$ e $1 \mathrm{ml}$ de HCIO 70\%, servindo como ponto de partidapara a maior parte dasdeterminações (SARRUGE \& HAAG, 1974).

Após a digestão feita em tubos de ensaio,foram adicionados $10 \mathrm{ml}$ de água destilada deionizada a cada tubo, procedendo-se a diluição do conteúdo do fundo e das paredes. Adicionou-se, a seguir, água destilada suficiente para completar o volume de cada tubo a $50 \mathrm{ml}$, estando assim preparados os extratos para determinação dos nutrientes.

As concentrações de $\mathrm{K}$, Ca,Mge S foram expressas em porcentagens na matéria seca a $65^{\circ} \mathrm{C}$ e as de Cu, Fe, Mn e $\mathrm{Zn}$ em ppm; as determinações foram realizadas através de leituras em espectrofotômetro de absorção atômica. 
O F foi determinado por colorimetria pelo método do vanadato-molibdato de amónio e suas concentraçбes expressas em porcentagens na matéria seca a $65^{\circ} \mathrm{C}$.

O micronutriente $B$ foi determinado pelo método da curcumina, com leituras no colorimetro fotoelétrico klett -Summerson (SARRUGE \& HAAG, 1974).

O preparo do extrato de material vegetal, para as determinações dos micronutrientes cobalto $e$ molibdênio, foi o seguinte: a) transferiu-se 5,0 g de amostra seca e moida para um cadinho de porcelana e incinerou-se a $500^{\circ} \mathrm{C}$ durante três horas ou mais (cinzas esbranquiçadas); b) juntouse $5 \mathrm{ml}$ de HCl $6 \mathrm{~N}$ e evaporou-se em banho-maria; c) dissolveuse. o residuo em $10 \mathrm{ml}$ de $\mathrm{HCl} \mathrm{N}$; d) usou-se $5 \mathrm{ml}$ para determinaçåo do cobalto; e) pipetou-se $5 \mathrm{ml}$ para a determinaçăo dó Mo, juntou-se. $5 \mathrm{ml}$ de $\mathrm{HCl} 3 \mathrm{~N}$. .

O cobalto foi complexado com 2-nitroso-1- naftol extraido em acetato de isomila e determinado por especkrofotiometria no visivel (BATAGLIA et alị, 1983).

o molibdênio foi determinado pelo método colorimétrico do cloreto estanhoso e do tiocianato (SARRUGE \& HAAG, 1974).

\subsubsection{Análise do Solo}

Foram coletados amostras de. solo, vaso por va-. so, juntando-se o material das quatro repetiçőes, tratamento por tratamento. 0 solo foi amostrado antes da aplicação do calcário, após o período de incubação e na época de colheita final de cada experimento. Os parâmetros analisados foram: pH em $\mathrm{CaCl}_{2}$, matéria orgânica (\%), $\mathrm{Ca}^{2+} \mathrm{e} \mathrm{Mg}^{2+}$ trocáveis, $\mathrm{H}^{+}+\mathrm{Al}^{3+}$ 
trocáveis, $K$ expressos em emg/100 ml de TFSA e P em microgramas por ml de TFSA. As análises foram efetuadas pelo Labo ratório de Fertilidade do Solo do Instituto Agronômico de Campinas, sendo empregada a resina trocadora de ions (RAIJ \& QUAGGIO, 1983).

\subsubsection{Análises Estatisticas}

As análises de variância, comparações de médias, através do Teste de Tukey, e as análises de regressão foram realizadas, através dos programas SAS, descritos por FREUND \& LITTELL (1981). Os procedimentos da correlação foram descritos no SAS (1982). 
4. RESULTADOS E DISCUSSÃO

4.1. Crescimento e Nitrogênio Total Acumulado na Parte Aérea do Capim Colonião

Os efeitos dos tratamentos de calagem e da adu baçăo fosfatada sobre o crescimento em termos de produção de matéria seca da parte aérea do capim colonião cV. IZ-1, em quatro cortes, estão resumidos na Tabela 11.

A análise de variância (Tabela 12) : i.rievelou efeitos significativos $(P \leqslant 0,01)$ da aplicação de fósforo so bre as produções de matéria seća nos quatro cortes e no total (soma dos quatro cortes) e, das interações fósforo $\times$ calagem $(P \leqslant 0,01)$ no primeiro, segundo e no quarto corte ( $P \leqslant$ $0,05)$. Também foi significativo $(P \leqslant 0,05)$ o efeito dos micronutrientes no quarto corte $e$ a interação fósforo $x$ micronutriente $(P \leqslant 0,05)$ na produção de matéria seca do segundo corte do capim coloniăo.

Observou-se resposta positiva do colonião a adubação fosfatada até a dose de $200 \mathrm{ppm}$ de fósforo. COSTA 
et alil (1983) também obtíveram máximas produtividades para - capim colonião mediante a adiçăo de 250 ppm de $P$ ao solo. As produções de matéria seca da parte aérea do capim coloniåo, total de quatro cortes, mediante a aplicação de apenas 20 ppm de $\mathbf{P}$ corresponderam a aproximadamente 55\% das produções alcançadas com a adiçăo de 200 ppm de fósforo tanto na presença como na ausência de calagem. Essas respostas do coloniăo a adubaçăo fosfatada corroboram com o relatado por outros pesquisadores, tais como, WERNER et alii (1967); SERRĀo et alii (1979), MII ITALIANO et alii (1982a); AZEVEDO \& SOUZA (1982b). e ressaltam a importância 1 de um nivel adequado de adubação fosfatada para o . máximo crescimento do capim coloniãó.

A produção da matéria seca da parte aérea do cápim coloniăo no terceirọ corte, foi incrementada com a adu bação fosfatada, sendo os dados melhor ajustados a um modelo quadrático, conforme a equaçåo $\dot{y}=7,94+0,047 x-0,00011 x^{2}$, onde $\gamma^{i}$ representa as produções de matéria seca $e x$ as quantidades de $P$ aplicadas (ppm), indicando para esse corte, que a máxima produção de matéria seca seria estimativamente obti da para doses superiores a 200 ppm de.P.

Para as produções de matéria seca, no primeiro corte, o desdobramento das interaçőes fósforo $x$ calagem revelou que a calagem nå teve efeito significativo na presença do menor nivel de adubaçăo fosfatada (20 ppm de P), porém com a aplicaçăo de niveis mais elevados de fósforo. a utilizaçåo de calcário resultou em efeitos positivos e sigṇ ficativos. Entretanto, no segundo e quarto cortes, a prática da calagem teve efeito significativo incrementando as produções de matéria seca desde o emprego da menor dose de fós- 
foro. As figuras 1 e 2 ilustiam esse fato e, ressaltam que incrementos mais elevados na produçăo de matéría seca foram obtidos nos niveis 100 e 200 ppm de P em comparaçăo com os efeitos do $P$ na ausência de calagem.

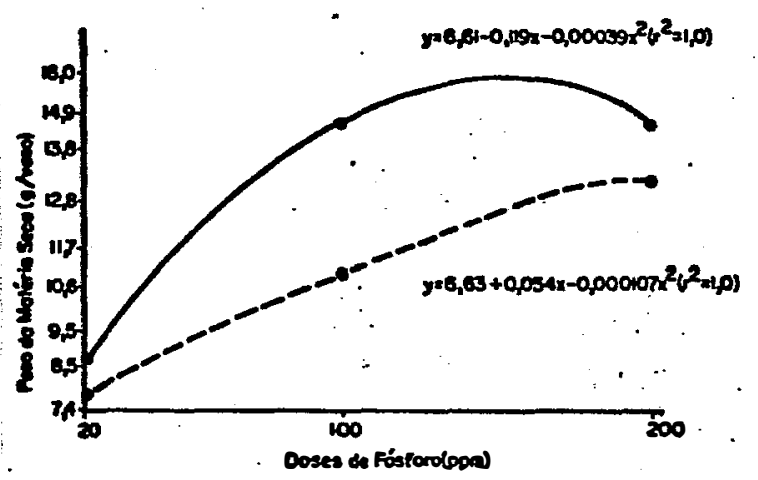

Figurol Produpāo de motério seco do porte céreo do copim Coloniōo em funcōo dos niveis de fósforo, no ousêncio (----) Ou no presenço de cologem (-). Dodos do segundo corte.

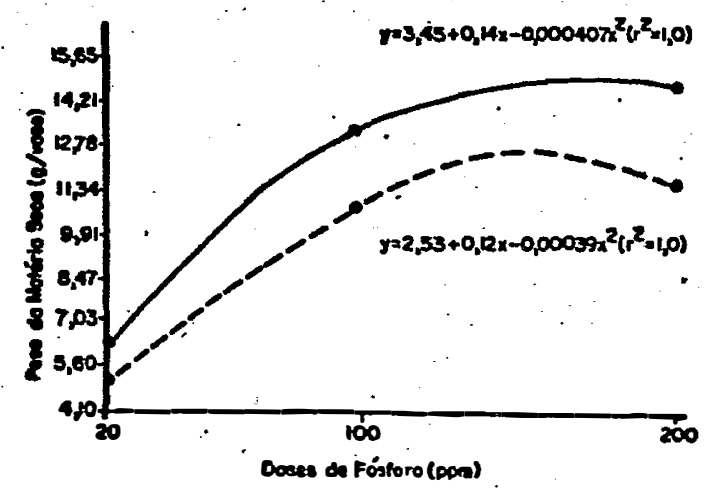

Figuro 2. Produçōo de motério seco do porte oéreo de copim Colaniōo em funçoo dos niveis de fósforo no ausência (----) lou no preeenpo de colagem (—). Dodos do quorto corte. 
A aplicação de fósforo proporcionou acentuados incrementos. nos teores de $P$ no solo porém não afetou os valores de pH (Tabela 6). Correlacionando-se os teores de fósforo no solo com a produção de matéria seca do coloniăo total de quatro cortes observou-se éfeitos positivos e signifí catios $\left(I=0,87^{*}\right)$. A fonte de fósforo (superfosfato simples) mostrou-se também como eficiente fornecedora de $\mathrm{Ca}^{++}$ ao solo, elevando os conteúdos desse nutriente. Observou-se reduçăo nos niveis de potássio. Esse fato pode ser facilmente explicado como consequência da maior extração, em virtude do maior crescimento nos nịveis mais elevados de adubaçåo fosfatada.

A calagem, elevandó o pH, aumentou a eficiência do fósforo aplicado. Alguns fatores associados com a aci dez do solo podem ser responsáveis pelas restriçőes de crescimento na ausência de calagem. Conforme mostram os dados da análise quimica do solo apresentados na Tabela . 6, o so 10 é deficiente em $\mathrm{Ca}+\mathrm{Mg}$, apresentando conteúdos elevados de $H+A l$, juntamente com valores baixos de $\mathrm{pH}$, contribuiram para prejudicar o crescimento adequado do coloniåo. É fato conhecido que a calagem, em solos ácidos e deficientes em $\mathrm{Ca}, \mathrm{Mg}$ e P, atua beneficamente, elevando o $\mathrm{pH}$, com consequen te liberação do fósforo e molibdênio, incorporaçăo de cálcio e magnésio ao solo e diminuiçạo do aluminio trocável. A correlação entre o indice de saturaçăo em bases do solo com a produção de matéria seca total de quatro cortes mostrou-se positiva e significativa $(I \doteq 0,67 * *)$.

Para o segundo corte, a interação fósforo $x$ mi cronutriente foi estatisticamente significativa, desdobrando-se essa interaçăo observou-se que o fósforo aumentou a 
produção de matéria seca tanto na presença como na ausência de micronutrientes, enquanto que os micronutrientes não afetaram significativamente os rendimentos de matéria seca em nenhum dos níveis de adubação fosfatada. Entretanto, a aplicação de micronutrientes teve efeito significativo $(P<0,05)$ e positivo sobre a produção de matéria secạ do capim coloniăo no quarto corte (Tabela 12). A literatura, raramente, relata respostas do capim coloniăo a aplicação de micronutrientes, uma vez que esses nutrientes săo exigidos em peque nas quantidades e podem estar presentes no solo ou ser adicionado como contaminante de calcário ou de : fertilizantes. Porém, após cortes sucessivos, as crescentes extraçóes resul taram, no quarto corte, que a nåo aplicaçåo de micronutrientes limitou o crescimento do capim coloniåo.

A tentativa de estabelecer prováveis correlaçôes entre as produçőes de matéria seca do capim coloniåo em cadacorte com osrespectivos teores de micronutrientes cobalto e molibdênio, evidenciou efeitos năo significativos.

Na Tabela 13 såo apresentadas as quantidades totais médias de nitrogênio acumuladas na parte aérea do capim coloniåo em função da calagem e dos niveis de adubação fosfatada. A análise de variância revelou efeitos significativos $(P \leqslant 0,01)$ da adubaçăo fosfatada, nos quatro cortes, da calagem nos dois últimos cortes, da interação fósforo $x$ micronutriente nos dois primeiros cortes e fósforo $x$ calagem no primeiro corte. observou-se que a calagem, no primeiro corte, teve efeito significativo em todos os niveis de aduba ção fosfatada sobre as quantidades totais de nitrogênio acumuladas. A adubação fosfatada proporcionou incrementos com efeitos quadráticos sobre as quantidades totais de nitrogê- 
nio no primeiro corte tanto. em presença comó na ausência de calagem.

Por outro lado para as quantidades totais de nitrogênio da parte aérea (primeiro e segundo cortes) a inte ração fósforo $x$ micronutriente mostrou-se significativa ( $P \leqslant$ $0,01)$. Desdobrando-se essas interações verificou-se que a aplicação de micronutrientes teve efeito significativo e positivo somente na presença do maior nivel de adubaçåo fosfatada (200 ppm de P) para o primeiro corte, enquanto que, no segundo corte, já com a aplicação de 100 ppm de P emprégo de micronutrientes teve efeito significativo. Conforme pode ser observadó na Tabela 14 o efeito do fósforo, no primeiro corte, na presença e na ausência de micronutrientes foị quadrático. Entretanto, no segundo corte, sem a aplicação de micronutrientes o efeito do fósforo foi quadrático enquanto que com a aplicação de micronutrientes foi linear.

-As quantidades totais de nitrogênio da parte aérea do capim coloniåo no térceiro e quarto cortes foram mais elevadas na presença que. na ausência de calagem. A adubação fosfatada incrementou significativamente as quantidades totais de nitrogênio da parte aérea do quarto corte, os acréscimos obedeceram efeito quadrático $(Y=100,83+0,69 x$ $+0,0021 x^{2}$ ) com valores máximos estimados com a aplicação de 164 ppm de $P$.

4.2. Crescimento e Nodulação das Leguminosas

4.2:1. Soja-perene cultivada em solo Latossolo Vermelho Escuro \&lico (LEa)

Ass análises de variância para os dados de produção de matéria seca da parte aérea (em ambos cortes), das 
ralzes e da planta inteira, peso seco e número de nódulos da soja-perene cultivado no solo LEa são apresentadas na Tabela 15. A aplicação de calcário afetou significativamente todas as variáveis anteriormente citadas. A interação calagem $x$ mo libdênio também tevé efeito significativo sobre a produção de matéria seca da parte aérea da soja perene no primeiro corte. As demais interações não apresentaram efeitos signifi cativos sobre as diversas variáveis estudadas.

A aplicação de niveis de calcário, até a dose equivalente a 2,89 toneladas/hectare (calculada para elevar o indice de saturação em bases a 70\%) incrementou linear e. significativamente as produções de matéria seca na parte aérea (ambos cortes), nas raizes e na planta inteira e a nodulação (peso seco a número de nódulos), conforme ilustram os dados da Tabela 16. Esses resultados concordam com a maio ria dos estudos realizadós com essa espécie. Considerando a produção de matéria seca da parte aérea, ao se. comparar o nivel 0 de calagem $(\mathrm{pH} 4,1)$ com o nivel $2(\mathrm{pH}, 3)$ observou -se no segundo corte, que os rendimentos, em termos de produ ção de matéria seca, na ausência de calagem representaram cerca de $28 \%$ dos obtidos com a aplicação da calagem. Esses resultados confirmam a sensibilidade da soja-perene às condições de acidez do meio (SOUTO \& DÖBEREINER, 1969 e JONES \& FREITAS, 1970) e as respostas positivas a aplicação de calcá IIo (QUAGLIATO \& NUTI, 1969; LOVADINI, 1972 e MUNNS \& FOX, 1977a).

Originalmente após o periodo de incubação o so lo LEa apresentava baixos conteúdos de $\mathrm{P}, \mathrm{Ca}, \mathrm{Mg} \mathrm{e}$ acidez elevada (Tabela 7). A calagem alterou visivelmente algumas caracteristicas do solo, tais como $\mathrm{pH}$, teores de $\mathrm{Ca}^{2+}$. e $\mathrm{Mg}^{2+}$ 
trocáveis e saturação, em basies que foram elevadas, enquanto que os teores de $\mathrm{H}^{+}+\mathrm{Al}^{3+}$ foram diminuidos (Tabela 8 ).

Ressalta-se que a correlação entre o indice de saturação em bases do solo e a produção de matéria seca da soja perene cultivada nesse solo mostrou-se positiva e significativa $\left(r^{2}=0,89 * *\right)$.

Com relação ao peso da matéria seca da parte aérea no primeiro corte, a interação calagem $x$ molibdênio te ve efeito significativo. O desdobramento dessa interação mos trou que a calagem teve efeito positivo e linear (Tabela 17) incrementando a produção de matéria seca tanto na presença como na ausência de aplicação do molibdênio (Tabela 18). Por outro lado, o emprego do molibdênio, na ausência de calagem, incrementou a ṕrodução da matéria seca da soja-perene no pri meiro corte, também no nivel mais elevado da calagem a aplicação de molibdênio resultou em maiores produções de matéria seca. Na ausência de calagem, a baixa disponibilidade do molibdênio presente no solo explica os efeitos positivos da adição desse elemento. - Cóm a prática da cala gem deve ter ocorrido elevação na disponibilidade do Mo presente no solo ou do adicionado. Efeitos favoráveis da aplica ção de molibdênio sobre a produção de matéria seca da sojaperene também foram observadọ por JONES et alii (1970); WERNER \& MATTOS (1974) e MONTEIRO (1980).

A nodulação (peso seco e número de nódulos) da soja-perene cultivada nesse solo foi significativamente aumentada pela calagem, resultados semelhantes foram constata dos por MUNNS et alii (1977). Na ausência de calagem, a soja -perene teve uma nodulação inexpressiva (Tabela 16). Além de influenciar no desenvolvimento das plantas, a calagem deve 
ter melhorado o suprimento de cálcio e de magnésio para os nódulos. Segundo VIDOR et alii (1983) maiores quantidades de cálcio são requeridas durante ọ inicio do processo de infecção radicular, sendo que a partir dai menos cálcio é necessário para o crescimento e manutenção dos nódulos. No entanto, como a bactéria necessita de muito menos cálcio que a planta, a formação dos nódulos falharia muito antes da baçté ria ser afetada $e$, sendo o efeito do cálcio na formação e funcionamento dos nódulos dependente do seu teor na planta, é necessário amplo suprimento deste nutriente. No presente trabalho, na ausência de calagem, o.pH. situou-se em torno de 4,1, porém, com a aplicação de calcário proposta para eleva ção do indice de saturação em bases a $70 \%(2,89$ t de calcário por hectare), resultando valores de $\mathrm{pH}$ de 5,3 , proporció nou condições satisfatórias pạ̣a uma razoável nodulação.

Emi solos ácidos, a nodulação das leguminosas é também inibida ou reduzida pela presença de Al na solúção do solo (CARVALHO et alii, 1981). Tạl efeito varia entre espécies e com a concentração de Al. No presente trabalho não foi medida a concentração de Al na solução do solo, porém GONTARSKI (1) trabalihando com esse mesmó solo obteve na ausên cia de calagem 1,2 e.mg de $\mathrm{Al}^{3+} / 100 \mathrm{~g}$ de solo, o pH baixo e essa concentração por Al sugerem que esse fator tenha contri buido para inibição da nodulaçăo.

A correlação entre o indice de saturação em ba ses do solo e o peso. seco dos nódulos não foi significativa. Todavia, com a aplicação de calcário, o número de nódulos

${ }^{1}$ GONTARSKI; E.C. (Instituto de Zootecnia, Nova Odessa) Comunicação Pessoal, 1989. 
da soja-perene foi significativamente $\left(\mathrm{r}^{2}=0,87 * *\right)$ incremen tado com a elevação dos indices de saturação em bases do so10, sendo que a nodulação, no geral foi baixa. A importância relativa do $\mathrm{Al}, \mathrm{Mn}, \mathrm{pH}$; Ca e outros fatores relacionados com o pH nesse solo, interagindo na associação soja-perene Rhizobium foram responsáveis pela nodulação observada nesse experimento. Considerando a inter-relação que há entre esses fatores nas condições do presente experimento é dificil separar os efeitos isolados de cada um deles. Pode-se especular, entretanto, que a alta concentração de $\mathrm{H}^{+}$e de $\mathrm{Mn}^{++}$na solução do solo ou pH baixo reduziu a nodulação.

As equações de regressão coirrespondentes aos efeitos significativos para os niveis de calagem sobre produção de matéria seca na presença ou ausência de molibdênio são apresentadas na Tabela 17.

4.2:2. Soja-perene cultivada no solo Latossolo Vermelho Amarelo distrófico (LVd)

As produções de matéria seca da parte aérea no primeiro e no segundo corte, das raizes e da planta inteira, nodulação (peso seço e número de nódulos) da soja-perene cul tivada no solo LVd, em função dos niveis de calagem são apre sentadas na Tabela 19.

A análise de variância dos dados (Tabela 20) evidenciou efeitos significativos $(P \leqslant 0,01)$ para a calagem em todas as variáveis acima mencionadas. Entretanto, não foram significativos os efeitos da aplicaçăo de molibdênio, de cobalto e nem das interações molibdênio $x$ cobalto, calagem $x$ cobalto, calagem $\times$ molibdênio sobre as produções de matéria 
seca da parte aérea, das rafzes, da planta inteira e nodulação.

A produção de matéria seca da parte aérea, das ralzes, da planta inteira è nodulação, em geral, foram aumen tadas significativamente com a aplicaçåo de niveis crescentes de calcário, no entanto. a resposta variou entre os diver sos parâmetros estudados. A análise da regressão mostrou que, os dados se ajustaram melhor a um modelo linear ou quadrático, conforme mostram as equações de regressão apresenta dos na Tabela 21.

Comparando-se o nivel de calagem mais elevado com a ausência de calagem,observou-se que na ausência de cá lagem a produção de matéria seca do primeiro e do segundo cọrtes da soja-perene sofreram reduções da ordem de $47 \%$ e 80\%, respectivamente.

Respostas à aplicação de calagem no desenvolvimento da'soja-perene foram obtidas por vários ẩ autores como QUAGLIATO \& NUTI. (1969), LOVADINI (1972), FRANÇA et alii (1973) e MUNNS \& FOX (1977):

Na ausência da calagem, a nodulação expressa em termos de peso seco e número de nódulos foi baixa, enquan to que com a aplicação de calagem ela aumentou expressivamen te. Tanto o peso como o número de nódulos foram incrementados com a calagem, correlacionando-se positiva e significati vamente com a elevação dos indices saturação em base do so10. A baixa nodulação, na ausência de calagem, parece estar relacionada com o baixo pH do solo (Tabela 8) e aos altos $n \underline{i}$ veis de manganês no solo que. refletiram em niveis tóxicos na planta (Tabela 59). A alta concentração de $\mathrm{H}^{+}$na solução do solo também pode inibir a nodulação de leguminosas, embora com efeito variável entre espécies (ANDREW, 1976). 

Escuro álico (LEa)

Os resultados observados para a produção de matéria seca da parte aérea, das raizes e da planta inteira e o peso seco dos nódulos da centrosema cultivada no solo LEa são apresentados na Tabela 22.

As produções de matéria seca (parte aérea no segundo corte, raizes e planta inteira) e peso seco dos nódulos foram significativamente aumentadas pela aplicação dos niveis de calcário (Tabelas 22 e 23). Esses aumentos resultantes da calagem obedeceram efeitos lineares ou quadráticos conforme indicam as equações de regressões apresentadas na Tabela 24.

Incrementos na produçåo de matéria seca.para essa leguminosa com a calagem, também foram obtidos por ANDREW \& NORRIS (1961) e FRANÇA \& CARVALHO (1970). No primeiro te, a centrosema não respondeu a aplicação de calcário: Porém, no segundo corte, na ausência de cálagem, a produçăo de matéria seca da parte aérea da leguminosa foi aproximadamente $66 \%$ do máximo alcançado no nível 2 da calagem. Confirmando a sensibilidade da centrosema aos fatores de acidez; verificou-se uma correlaçăo positiva e significativa $\left(\mathrm{r}^{2 \cdot}=0,83^{*}\right)$ entre 0 crescimento em termos de matéria seca e os indices de saturação em bases do solo.

$$
\text { Quanto a nodulação, verificou-se que a cala- }
$$
gem afetou de modo benéfico o peso seco dos nódulos. Esses resultados concordam com os obtidos por DE POLLI et alii, (1976). ejonES et alii (1970). 0 peso seco dos nódulos, na ausência de : calagem: representou 
cerca de 75\% do máximo alcançado no nível máximo de calagem (nivel 2) revelando essa leguminosa boa capacidade em nodular, mesmo nas condições de elevada acidez ( $\mathrm{pH}=4,1$ e indice de saturação em bases do solo de 15\%). Porém a eficiência de firação desses nódulos foi baixa,conforme será discutido mais adiante no item 4.4.2. A correlação ẹtre a nodulaçåo entre (número e peso seco de nódulos) com o indice de satura çăo em bases do solo (Tabela 10) nåo foi significativa.

Ressalta-se, também que o emprego do cobalto favoreceu a nodulaçåo (peso seco dos nódulos) da centrosema. De um modo geral a nodulação da centrosema nesse solo foi satisfatória.

4.2.4. Centrosema cultivada no solo Latossolo Vermelho Amarelo distrófico (LVd)

Os resultados da análise de variância para os dados de produção de matéria seca da parte aérea, das raízes e da planta inteira e peso seco dos nódulos såo mostrados na Tabela 25. A calagem mostrou efeito significativo sobre a produção de matéria seca na parte aérea (segundo corte), na planta inteira, e no peso seco dos nódulos.

Na Tabela 26 pode-se observar os dados médios para as variáveis acima mencionadas em função dos três niveis de calagem estudados. As equações correspondentes às regressões significativas são apresentadas na Tabela 27.

As produções de matéria seca (parte. aérea e planta inteira) e peso seco dos nódulos foram significativa e linearmente aumentadas pela aplicação de níveis de calcário. Esses resultados concordam com os obtidos por ANDREW \& 
NÖRRIS (1961), OUBEREINER \& ARONOVICH (1966); JONES . et alii (1970) e MONTEIRO (1980). A produção de matéria seca na ausência de calagem chegou a $54 \%$ do máximo obtido no nivel 2 de calagem, tais valores são bastante semelhantes aos verificados por ANDREW \& NORRIS (1961).

Com relação a nodulação, constatou-se que a ca lagem beneficiou de modo linear o peso seco dos nódulos da centrosema cultivado nesse solo. Resultados similares foram encontrados por WERNER \& MATTOS (1972). Observou-se que, mésmo na ausência de calagem, o peso seco dos nódulos da centrosema foi consideravelmente alto. É possivel que o cálcio disponivel no solo, (Tabela 10) proveniente da adubação fos fatada básica, mesmo ra ausência de aplicação de calcário (teòr de cálcio de 0,90 equivalentes miligrama por $100 \mathrm{ml}$ de terra fina seca ao ar) tenho sido suficiente para o estabele cimento da nodulaçåo, segundo MUNNS (1970) o cálcio é importante na infecção das raizes durante a formação de nódulos. A prática da calagem reduzindo os teores de $\mathrm{H}^{+}+\mathrm{Al}^{+++}$de 3,4 equivalentes miligrama por $100 \mathrm{ml}$ de TFSA (sem calagem) para 2,4 e.mg/100 $\mathrm{ml}$ de TFSA, juntamente com um maior suprimento de cálcio e magnésio podem ter sido responsáveis pelo incremento da massa nodular, considerando o importante papel desses nutrientes na formação do nódulo e na nutrição do Rhizobium (NORRIS, 1959). .

Observando-se as equações de regressão apresentados na Tabela 27 para o peso seco dos nódulos e produção de matéria seca, em função dos niveis de calagem estudados, verificou-se que valores máximos para essas variáveis seriam obtidos com doses de calcário superiores às testadas no presente trabalho. 
4.2.5. Galáctia cultivada no solo Latossolo

- Verme.lho Escuro álico (LEa)

Na Tabela 28 são apresentados os dados da análise de variância para algumas variáveis estudadas na galáctia cultivada no solo Latossolo Vermelho Escuro álico, em função da aplicação da calagem, molibdênio e cobalto.

Para os dados de produção de matéria séca da parte aérea, em ambos cortes, produção de matéria seca das raizes, da planta inteira e peso seco dos nódulos, a calagem mostrou efeito significativo.

Na Tabela 29 pode ser observado os dados de produção de matéria seca e peso seco dos nódulos da galáctia cultivada no solo LEa sob a aplicação das dosës de calcário. A análise de regressão revelou efeito linear positivo e significativo dos niveis de calagem, elevando a produção de matéria seca e o peso seco dos nódulos. Resultados similares foram obtidos por CARVALHO et alii (1988) cultivando a galác tia em um solo Latossolo Vermelho Amarelo álico em Minas Gerais.

Conforme pode ser observado na Tabela 9 , a aplicação dos niveis de calagem, como era esperado, resultou em elevações nos indices de saturação em bases do solo. Correlacionando-se esses indices de saturação em bases com a produção de matéria seca dos dois cortes, com o peso seco ou com o número de nódulos observaram-se valores positivos e sig nificativos pelo teste $t$ ao nivel de $1 \%$ de probabilidade. Por outro lado sobre as produções da matéria seca da parte aérea no primeiro corte, peso seco das raizes e da planta inteira, os niveis de calagem mostraram efeito quadrático. 
As equações de regressão representativas das variações desses parâmetros com a calagem podem ser apreciados na Tabela 30.

A interação calagem $\times$ cobalto para a produção de matéria seca do primeiro corte foi significativa. Na ausência de calagem, a aplicação de cobalto aumentou significa tivamiente a produção de matéria seca na parte aérea da galác tia cultivada nesse solo. Entretanto com o emprego da calagem a utilização de cobalto não alterou significativamente os rendimentos de matéria seca da galáctia (Tabela 31 ).

Embora a nodulação foi aumentada pela calagem, de uma-maneira geral, o peso seco dos nódulos foi bastante baixo, indicando que as estirpes de Rhizobium presente ou inoculada no solo deixaram a desejar com relação a infeç̧ão radicular. (Tabela 29 ).

4:2.6. Galáctia cultivada no solo Latossolo Vermelho Amarelo distrófico ( LVd)

As análises de variância dos dados de produção de matéria seca da parte aérea, das raizes, da planta inteira e peso seco dos nódulos da galáctia cultivada no solo Latossolo Vermelho Amarelo distrófico são apresentadas na Tabela 32. Com exceção ao peso seco das raizes, a calagem teve efeito significativo sobre todas as variáveis anteriormente citadas. A aplicação de molibdênio mostrou efeito significativo sobre a produção de matéria seca do segundo corte, da planta inteira e peso seco dos nódulos. Por outro lado, a aplicação do cobalto, e as interações calagem $x$ molibdênio, calagem $x$ cobalto e molibdênio x cobalto não apresen- 
taram efeitos significativos sobre as produçōes de. matéria seca e nodulação.

Na Tabela 33 são apresentados os dados de produção de matéria seca da parte aérea e das raizes, e peso se co dos nódulos da galactia cultivado no solo LVd em função dos niveis de calagem. A análise de regressåo 1, i, evidenciou efeito linear e significativo dos niveis de calagem incremen tando a produção de matéria seca no segundo corte e o peso seco dos nódulos (Tabela 33). Resultados similares foram obtidos por MONTEIRO (1980), cultivando a galactia num solo Podzólico Vermelho Amarelo, dados do primeiro corte. Entretanto, para as produções de matéria seca (10 corte) e da planta inteira, os niveis de calagem tiveram efeito quadrátịco. As equações de regressão correspondentés às regressões significativas såo apresentadas na Tabela 34.

A aplicação de calcário no nivel 2 (calagem para elevação do indice de saturação em bases a 70\%) aumentou ẹm 80\% a produção da matéria seca no segundo corte, quando comparado com o tratamento sem aplicação de calcário. A correlação entre os indices de saturaçăo em bases (Tabela 9) e a produção de matéria seca da galactia total de dois cortes foi positiva e significativa ao nível de 5\%. Por outro lado a nodulação, na ausência de calagem, representa cerca de 69\% do máximo alcançado com a maior dose de calcário aplicada. Este fato demonstra que a galactia cv. Iarana apresenta certa exigência em termos de correção da acidez, demonstran do maior crescimento na presença da dose mais elevada de cal cário empregada. Såo necessários futuros estudos comparativos sobre as exigências em termos de calagem ou tolerância aos fatores de acidez para os diversos cultivares de galac- 
tia, uma vez que os estudos iniciais (MATTOS \& WERNER, 1972) com essa leguminosa, utilizando outra cultivar, não demonstraram reduções significativas na matéria seca mediante a omissåo da calagem.

.0 emprego do molibdênio resultou em acréscimos nas produções de matéria seca do segundo corte, da planta inteira, peso seco dos nódulos. Verificou-se que, no primei ro corte, a galactia não respondeu a aplicação de imolibdênio, pois provavelmente parte do nitrogênio necessário ao seu metabolismo foi proveniente da matéria orgânica do so10. Já, no segundo corte, exaurida a reserva do $\mathrm{N}$ mineral do solo, a planta passou a ser mais dependente da fixação bioló gica do $\mathrm{N}$ para atendimento de sua demanda. Os conteúdos de Mo do solo ou o metabolizado das reservas da semente de galactia, no segundo corte, passaram a ser limitantes de modo que a aplicação de molibdênio incrementou significativamente o peso seco dos nódulos, as concentrações de nitrogênio (Tabelas 32 e 80 ) da galactia, refletindo em maiores produções de matéria seca. Respostas a aplicação de Mo em leguminosas forrageiras foram obtidas por diversos autores (MANNETJE et alii, 1963; HALL, 1970; WERNER \& MATTOS, 1974; EMBRAPA, 1980; PAULINO et alii, 1985 e MONTEIRO et alii, 1987).

\subsection{Composição Mineral}

4.3.1. Coloniåo

4.3.1.1. Teores de Macronutrientes

Os teores de macronutrientes na parte aérea do capim coloniăo em quatro cortes săo apresentados na Tabela 35 e 36. 
Nitrogênio

Os valores médios de nitrogênio apresentados na Tabela 35 ( 1,59 a 2,43\% de N) săo considerados adequados para o capim colonião (WERNER \& HAAG, 1972). A análise de variância (Tabela 37) mostrou efeito significativo, sobre os teores de nitrogênio para adubação fosfatada nos quatro cortes, para a calagem no primeiro, no segundo e no quairto cortes, e para a interação fósforo $x$ calagem no segundo corte. $\dot{0}$ s contrastes demonstraram variação inversa com relação ao crescimento das plantas, encontrando-se teores menores nos tratamentos onde foi observado maior crescimento. A interação fósforo $x$ calagem para os teores de $N$ do segundo corte foi significativa e, desdobrada (Tabelas 38 e 39 ) mostrou efeito quadrático significativo do fósforo na ausência e na presença de calagem. No segundo corte, com a aplicação de calcário os teores de nitrogênio foram significativamente mé nores quando comparados aos obtidos na ausência de calagem. Essas reduções são atribuidas aos efeitos de diluição em vir tude do maior crescimento do capim cöloniaao na presença de calagem. Semelhantemente ao observado no segundo corte, no primeiro e quarto cortes na ausência de calagem foram obtidos conteúdos de $\mathbf{N}$ mais elevados que na presença de calagem.

Fósforo

Os percentuais de fósforo, encontrados na parte aérea do capim colonião em função das doses de fósforo e mediante a aplicação ou não de calagem são apresentados na Tabela 35. 
A análise de variância mostrou efeito significativo sobre os teores de fósforo na matéria seca da parte aérea do capim coloniåo para a adubaçăo fosfatada $(P<0,01)$ nọ quatro cortes para aplicaçăo de micronutrientes no primeiro e terceiro cortes, para a calagem no segundo, terceiro e quarto cortes e para a interaçåo fósforo x calagem no primeiro, terceiro e quarto cortes.

Desdobrando-se a interaçåo calagem $x$ adubaçåo fosfatada observou-se que, no primeiro e no quarto corte, a aplicaçåo de calcário teve efeito significativo apenas com a aplicação de 200 ppm de P, enquanto que a adubação fosfatada tanto na presença como na ausência de calagem incrementou os tèores de fósforo. Verificou-se que a correlaçåo entre os teores de fósforo e a produçăo de matéria seca do coloniåo total de quatro cortes foi positiva e significativa. No terceiro corte, a calagem teve efeito significativo e positivo a partir da aplicaçăo de 100 ppm de $P$, porém com o emprego de somente 20 ppm de $P$ o efeito da aplicação de calcário năo foi significativo.

Na presença de calagem, a adubação fosfatada incrementou linearmente os teores de fósforo da parte aérea do capim coloniåo no primeiro, terceiro e quarto cortes. Já, na ausência de calagem, os efeitos da adubaçăo fosfatada foram quadráticos no primeiro e quarto cortes e linear no terceiro corte. As equações de regressão que representam esses efeitos da adubação fosfatada sobre os teores de fósforo na parte aérea do capim coloniăo na presença ou na ausência de calagem são apresentados na Tabela 38 .

Pode-se observar na Tabela 35 , que a concentra ção de fósforo no primeiro corte mediante a aplicação de 100 
ppm ou 200 ppm de fósforo situaram-se acima dos niveis estabelecidos como nível critico de fósforo por ANDREW \& ROBINS (1971), FALADE (1975), MARTINEZ \& HAAG (1980) para o capim coloniåo. 0 emprego da dose mais baixa de 20 ppm de P corres pondem a teores de fósforo inferiores a $0,18 \%$ de P.'Observase, ainda na Tabela 35, que os teores de fósforo na parte aé rea do capim coloniăo diminuiram a partir do primeiro corte até o quarto corte. Decréscimos nos teores de fósforo do capim coloniăo com a idade da planta, também foram observados por HAAG et alii (1967), PROSPERO \& PEIXOTO (1972); GOMIDE (1976) e NASCIMENTO JUNIOR et alii (1976).

Outro fato que chama a atençåo é que os teores de fósforo na parte aérea do capim coloniåo, a partir do segundo corte, em todos os niveis de adubação fosfatada, apresentaram-se deficientes para-atender as exigências animais médias em fósforo que são de $0,20 \%$ para animais adultos e de $0,34 \%$ para animais novos (NATIONAL ACADEMY OF SCIENCE, 1970). No presente trabalho, embora a adubaçåo fosfatada tenha aumentado expressivamente a concentração de fósforo, na parte aérea do capim coloniåo, a partir do segundo corte somente na presença de calagem e no nivel mais elevado de adubaçåo fosfatada foram obtidos teores de fósforo acima de $0,20 \%$.

\section{Potássio}

Conforme pode ser observado na Tabela 35, os teores de potássio variaram de 1,56 a 4,20\%. De acordo com VICENTE-CHANDLER et alii (1962) conteúdos de potássio de 1,5 2,0\% na matéria seca estariam associados a altas produçōes do capim coloniåo. 
A análise de variância para oš teores de potás sio evidenciou efeitos significativos para a adubação fosfatada nos quatro cortes, para a calagem no segundo, terceiro e quarto cortes, para aplicação de micronutrientes no primeiro e quarto cortes e para as interaçбes fósforo $x$ micronu trientes no primeiro, terceiro e quarto cortes e, fósforo $x$ calagem no primeiro e terceiro cortes. Os teores médios de potássio demonstraram variação inversa ao crescimento das plantas motivada pela maior disponibilidade de $P$. Isto pode sér explicado como consequência de diluiçăo do nutriente no interior da planta devido a maior produçã̃o de matéria seca, e, provavelmente, por antagonismo entre cálcio e o potássio.

Desdobrändo-se a interação fósforo $x$ calagem, verificou-se que no primeiro corte, a calagem só teve efeito significativo em reduzir os teores de potássio quando aplica do conjuntamente com 200 ppm de fósforo (superfosfato simples). Por outro lado, a adubação fosfatada diminuiu signifi cativamente os teores de $k$ tanto na presença como na ausência de calagem, no primeiro e no terceiro corteł. Verificouse que, no terceiro corte, na ausência de calagem e com o emprego de 20 ppm de $P$, os conteúdos de potássio foram superiores aos obtidos com a aplicação de calcário, entretanto a calagem năo teve efeito significativo quando foram empregadas doses mais elevadas que 20 ppm de $P$. A análise de regres såo evidenziou na ausência de calagem um efeito quadrático dos niveis de fósforo. (no primeiro e no terceiro cortes) enquanto que na presença de calagem, no primeiro corte o efeito foi quadrático porém no terceiro corte foi linear (Tabela 38). 
Desdobrando-se a interaçăo fósforo $x$. micronutriente (Tabela 37) observou-se que a adubaçåo fosfatada aumentando o crescimento, resultou em reduçọes sisignificativas sọbre os teores de potássio tanto na presença como na ausência de aplicaçăo de micronutrientes. Por outro lado, estudan do-se a influência dos micronutrientes dentro da adubação fosfatada verificou-se que foram obtidos, no primeiro corte conteưdos mais elevados de potássio mediante a aplicaçăo de micronutrientes na dose de 20 ppm de P, entretanto para do$\because$

ses superiores de $P$ adicionados, o efeito dos micronutrientes năo foi significativo. Já no quarto corte a aplicaçăo 1 de micronutrientes juntamente com 100 ou com 200 ppm de P resultou em conteúdos de $k$ significativamente menores, porém no nivel de 20 ppm de $P$ a utilizaçåo de micronutrientes năo alterou significativamente os teores de potássio.

Os decréscimos sobre os teores de potássio na parte aérea do capim coloniăo (no primeiro e no quarto corte) em função da aplicaçăo de niveis crescentes de $P$ juntamente com a adiçăo de micronutrientes obedeceram efeitos qua dráticos. No entanto, a utilizaçăo dos níveis de fósforo, sem aplicaçăo de micronutrientes, mostraram efeito quadrático para os teores de $K$ no primeiro corte, enquanto que no quar-. to corte o efeito foi linear (Tabela 39).

\section{cálcio}

De uma maneira generalizada os teores de cálcio na matéria seca da parte aérea do capim coloniåo estão na faixa considerada normal de 0,40 a $1,02 \%$ de Ca por MALAVOLTA et alii (1974). 
A análise de variância mostrou efeito significativo ( $P<0,01$ ) para aplicação de fósforo (segundo, terce ro e quarto cortes), para calagem (nos quatro cortes), para aplicação de micronutrientes $(P \leqslant 0,05)$ no segundo corte $e$ para as interaçð̃es fósforo $x$ calagem $(P \leqslant 0,01)$ no primeirọ, segundo e terceiro cortes sobre os conteúdos de cálcio na matéria seca do capim coloniáo (Tabela 40).

Desdobrando-se a interação fósforo $x$ 'calagem observou-se que na ausência de calagem a aplicaçăo de quantị -

dades crescentes de fósforo teve efeito positivo, significativo e quadrático (ṕrimeiro e segundo cortes) e linear (no terceiro corte). Já, na presença de calagem a adubação fosfa täda teve efeito significativo quadrático (no primeiro cortẹ) e linear (no terceiro corte). enquanto que no segundo corte seu.efeito nåo foi significativo (Tabela 38).

Como era esperado a aplicaçåo de calcário, que e fonte de cálcio incrementou significativamente os teores de Ca na planta nos niveis de adubaçåo fosfatada $\left(P_{20}=20\right.$ ppm e $P_{100}=100$ ppm de P) nos três primeiros cortes, enquan to que na dose mais elevada de adubação fosfatada ${ }_{200}=$ 200 ppm de P) o efeito da calagem não foi significativa nos dois primeiros cortes, porém no terceiro corte a calagem elevou significativamente os teores de cálcio. Ressalta-se que os incrementos nos teores de cálcio na parte aérea do capim coloniăo corresponderam a aumentos significativos na produção de matéria seca.

Magnésio

Os teores de magnésio variaram dentro de uma faixa de 0,14 até $1,16 \%$, sendo os limites superiores bastan 
te elevados com relação aos encontrados por BUTLER. \& JONES (1973) e MALAVOLTA et alii (1974) que obtiveram para plantas normais de coloniăo por volta de $0,20 \%$ de $\mathrm{Mg}$ na matéria seca. Conforme.ilustram os dados apresentados na Tabela 36 tanto na presença como na ausência de calagem, os teores de magnésio na parte aérea do capim colonião diminuiram do pri meiró para o segundo corte e assim sucessivamente.

A análise de variância dos teores de 'magnésio evidenciou que a adubaçăo fosfatada teve efeito significativo no segundo corte $(P \leqslant 0,01)$ e no terceiro corte ( $P \leqslant$ 0,05). A aplicação de micronutrientes resultou em acréscimos significativos $(P \leqslant 0,01)$ nos teores de magnésio no terceiro corte. A calagem teve influência significativa nos teores de 'magnésio nos quatro cortes, este fato é atribuido ao emprego de calcário, contendo em média 20\% de MgO, em quantida dés equivalentes a utilizaçăo de $190 \mathrm{~kg}$ de $\mathrm{Mg} / \mathrm{ha}$.

Observou-se que a intèração fósforo $\times$ calagem foi significativa no primeiro, no segundo e no quarto cortes (Tabela 40). Desdobrando-se essas interações verificou-se que a calagem elevou os conteúdos de $\mathrm{Mg}$ em todos os niveis de adubação fosfatada. Por outro lado, a utilização de fósfo ro na'ausência de calagem reduziu significativamente os teores de Mg apenas no primeiro corte, enquanto que, a adubação fosfatada na presença da caḷgem, no segundo e quarto cortes mostrou tendências de redução.

As equações de regressão representativas dos efeitos dos niveis de adubaçåo fosfatada na presença ou na ausência de calagem são móstradas na Tabela 38 .

Paré os conteúdos de magnésio na matéria seca do terceiro corte do capim coloniăo foi significativa a intera- 
çåo micronutriente $x$ calagem. Desdobrando-se essa interaçåo observou-se maiores acumulaçőes de magnésio na parte aéréa do capim coloniåo na presença de calagem e de micronutrientes. A aplicação de calcário (contendo Mg) tanto em presença como na ausência de micronutrientes, incrementou os conteúdos de Mg do capim coloniăo (Tabela 41).

Enxofre

Os teores de enxofre na parte aérea dạs plantas de coloniăo apresentaram uma faixa de variaçăo de 0,08 a 0,17\% (Tabela 36). SMITH \& SIREGAR (1983) apresentaram dados para um grupo de gramineas forrageiras tropicais, entre as quais estava um Panicum, sugerindo como nivel critico de enxofre para tais plantas, aos 28 dias de rebrota, entre 0,07 e $0,11 \%$ de énxofre.

Embora a fonte de fósforo empregada foißo superfosfato simples que contém enxofre, os efeitos da adubaçåo fosfatada sobre os teores de enxofre, só foram significativos $(P \leqslant 0,05)$ no.segundo corte. A análise de variância (Tabela 40) para os teores de enxofre revelou valores significativos para os efeitos dos micronutrientes no primeiro corte $(P \leqslant 0,01)$, no terceiro corte $(P \leqslant 0,05)$, da calagem nos dois primeiros cortes $(P \leqslant 0,01)$, e da interação fósforo $x$ micronutriente: no primeiro corte. 0 desdobramento da interaçăo fósforo $x$ micronutriente mostrou que a aplicação de fósforo teve efeito significativo positivo e linear com ou sem aplicação de micronutrientes sobre os conteúdos de en xofre, porém à utilização de micronutrientes corresponderam teores mais baixos de enxofre no nivel mais elevado de aduba ção fosfatada. 
0 desdobramento da interação fósforo $x$ : cala: gem, para os teores de enxofre no terceiro corte : :mostrou efeito significativo e negativo da calagem apenas na. menor dose de adubação fosfatada; enquanto que a aplicação de fósforo na ausência de calagem teve efeito significativo quadrá tico sobre os. teores de enxofre na matéria seca do terceiro corte do capim coloniåo (Tabelas 36 e 40).

4.3.1.2. Teores de Micronutrientes

Boro

Os teores de boro na matéria seca da parte aérea săo apresentados nas Tabelas 42 e .43 , em funçăo dos diversos tratamentos de adubação: o valor minimo encontrado foi de 11 ppm nos tratamentos sem à aplicação de micronutrientes e com a utilizaçåo de 20 ou 100 ppm de fósfüro e o máximo de 36 ppm obtido na matéria seca do primeiro corte mediante a utilização de micronutrientes e 20 ppm de fósforo como superfosfato simples.

A análise de variância (Tabela 4.4)

mostrou efeito significativo para a adụbaçåo fosfatada, micronutrien tes nos quatro cortes e para calagem no segundo corte. Foram também significativas as interações fósforo $x$ micronutrientes (primeiro, terceiro e quarto cortes), fósforo x calagem (segundo corte) e micronutrientes $x$ calagem (quarto corte). 0 desdobramento da interação fósforo $x$ micronutriente demonstrou para os teores de $B$ no primeiro e no quarto cortes, que a adubaçăo fosfatada nåo teve efeito significativo na ausência de aplicação de micronutrientes, po- 
rém no terceiro corte o efeito foi significativo e quadrático. Entretanto, com o emprego de micronutrientes a adubação fosfatada reduziu significativamente linearmente os teores de boro no primeiro, terceiro e quarto cortes (Tabelas 43 e 44).

Na Tabela 39 são apresentadas as equações de regressão representativos dos efeitos da adubação fosfatada sobre os teores de boro com ou sem aplicação de micronutrien tes.

Por outro ládo, a aplicação de micronutrientes, incluindo o boro, resultou em acréscimos significativos e positivos sobre os teores de boro na matéria seca da parte aérea do capim colonião no primeiro e terceiro cortes em todos os niveis de adubação fosfatada e, no quarto corte para os niveis mais baixos de adubação fosfatada ( 20 e 100 ppm de fósforo). Para os dados do segundo e do quarto cortes, no maior nivel de adubaçåo fosfatada a aplicaçåó de micronutrientes nåo afetou significativamente os teores de boro.

Desdobrando-se os dados do segundo corte para a interação calagem $x$ adubação fosfatada, observou-se que a calagem não teve efeito significativo em nenhum nivel de adubação fosfatada, enquanto que a adubaçăo fosfatada na pre sença de calagem proporcionou reduçōes lineares (Tabelas 38 e 42). Por outro lado desdobrando-se a interaçăo micronutriente $x$ calagem verificou-se que a aplicaçåo de micronutrientes incrementou significativamente os teores de boro na matéria seca da parte aérea no quarto corte do capim colo niăo tanto na presença como na ausência de calagem. Entretan to, analisando-se os efeitos da calagem, observou-se que, somente mediante a aplicaçăo de micronutrientes, os teores - de boro foram diminuidos pela calagem (Tabela 41). 
Cobre

O teor de cobre ṇa parte aérea do colonião em função da aplicação de miçronutrientes e fósforo são apresentados na Tabela 43. O valor minimo encontrado foi de 2,5 ppm obtido no segundo corte para o tratamento sem aplica ção de micronutrientes e com o emprego de 200 ppm de $P$ e 0 máximo de 13 ppm obtido com a aplicação de micronutrientes e 20 ppm de P. A média de 7,7 ppm encontrada no experimento es tá acima da faixa $(2,7-4,1$ ppm Cu) encontrada por SOUZA et alii (1979) e acima da média obtida (6 ppm) para as gramíneas cultivadas em são Paulo (GALLo et alii, 1974).

A análise de variância (Tabela 44) mostrou efeitós significativos $(P \leqslant 0,01)$ para a adubaçăo fosfatada nos quatro cortes, para aplicaçåo de micronutrientes no primeiro, segundo équarto cortes, enquanto que a calagem, apenas no primeiro corte, teve efeito significativo $\left(P \leqslant^{3} 0,05\right)^{\circ}$.

Desdobrando-se a interação fósforo $x$ micronutriente, verificou-se no segundo corte que a aplicação de mi cronutrientes elevou os teores de cobre na parte aére do capim coloniăo em todos os niveis de adubaçăo fosfatada. Por outro lado, a adubação fosfatada proporcionou reduções sign ficativas ( $P \leqslant 0,01$ ) nos teores de cobre com efeitos quadráticos tanto na presença como na ausência de calagem (Tabela 38 e 44). No desdobramento da interação fósforo $x$ micronutriente referentes aos dados do quarto corte observou-se efeito significativo e positivo da aplicaçåo de micronutrien tes nos niveis de 20 e 200 ppm. de P. De maneira semelhante ao segundo corte, a adubação fosfatada no quarto corte impli cou em reduções nos teores de cobre, lineares na ausência de 
micronutrientes e com efeito quadrático na presença de micronutrientes. As equações de regressão representativas dessas variaçōes são apresentados na Tabela 39.

\section{Zinco}

As Tabelas 42 e 43 apresentam as variações dos teores de zinco na parte aérea das plantas de colonião em função dos diversos tratamentos. A oscilação encontradas está em torno da média apresentada por GALLO et alii (1974), sendo os teores mais elevados, $50 \mathrm{ppm}$ de $\mathrm{Zn}$, obtidos no primeiro corte no tratamento com a aplicação de micronutriente e adubação fosfatada. Na ausência de apliçação de micronutrientes e mediante a adubação fosfatada, os teores de $Z n$, no quarto corte, móstraram expressivas reduções abaixo do valor de 20 ppm apontado como. ideal por EPSTEIN (1975).

A análíse de variância (Tabela 44) mostrou efeitos significativos $(P \leqslant 0,01)$ para a adubação fủsfatada no primeiro, segundo e quarto cortes, para aplicação de micronutrientes nos quatro cortes, para calagem nos dois primeiros cortes, para as interações fósforo $x$ micronutrientes $(P \leqslant 0,05)$ e fósforo $\times$ calagem $(P \leqslant 0,01)$ no terceiro corte e, micronutriente $x$ calagem $(P \leqslant 0,05)$ no primeiro corte.

Desdobrando-se a interação fósforo $x$ micronutriente verificou-se no primeiro corte efeitos quadráticos significativos da adubação fosfatada tanto na presença como na ausência de micronutrientes. Neste mesmo corte, a aplicação de micronutrientes resultou em teores mais elevados de zinco em todos os niveis de adubação fosfatada. Já no segundo corte, na ausência de aplicação de micronutriente e adubação fosfatada não teve efeito significativo 'sobre os teores 
de $\mathrm{Zn}$, entretanto na presença de micronutrientes mediante a utilização de doses de adubação fosfatada houve redução 11near nos teores de $\mathrm{Zn}$.

Essa interação entre o fósforo e o zinco é conhecida como deficiência de zinco induzida pelo fósforo. De um modo geral, esse fato tem sido atribuido a quatro possiveis causas: a) interação $P-Z n$ no solo; b) o $P$ inibe não com petivamente a absorção de zinco; c) uma taxa de tránslocação de $\mathrm{Zn}$ mais lenta das raizes para a parte aérea devido a uma resposta de crescimento a $P$; e d) uma desordem metabólica in tracelular relacionada a um desbalanço entre $P$ e $Z n$, ou uma concentração excessiva de $\dot{P}$ interfere com a funçåo metabólica do $\mathrm{Zn}$ em certos sitios nas células. Nas condições do presente experimento, as três primeiras causas podem explicar os efeitos ọbservajos com relaçăo a redução dos teores de Zn com a aplicaçăo do fertilizante fosfatado, porém a quarta e última causa parece ser pouco provável pois os 's teores de fósforo obtidos no primeiro e segundo cortes (Tabela 35) mediante aplicação de $P$ não são excessivas e estão próximos ao nivel critico para essa espécie (ANDREW \& ROBINS, 1971; FALADE, 1975).

Desdobrando-se a interação calagem $x$ micronutriente verificou-se que na ausência de aplicação de micronu triente a calagem não teve efeito significativo sobre os teores de zinco na parte aérea no primeiro e quarto cortes do capim coloniåo. Por outro lado com a aplicaçåo de micronu triente teores mais elevados de zinco foram obtidos na ausência de calagem, a aplicação de micronutrientes resultou em conteúdos mais elevados de $\mathrm{Zn}$ na parte aérea do capim coloniåo (Tabelas 41 e 44 ). As diminuições dos conteúdos de 
zinco com a calagem săo devidos as reduçőes na disponibilidą de desse micronutriente.

Verificou-se para os teores de zinco no tercei ro corte, que a interação calagem $x$ adubaçăo fosfatada foi significativa. O desdobramento dessa interaçăo evidenciou que a năo aplicaçăo da calagem mediante a aplicaçăo de 200 ppm de fósforo resultou em teores mais elevados de zinco. A utilizaçăo de doses de fósforo, na ausência de calagem, proporcionou reduçőes lineares sobre os teores de zinco na parte aérea do terceiro corte do capim coloniåo (Tabelas 38 e 42).

\section{Manganês}

- Os teores de Mn na matéria seca da parte aérea do capim coloniåo são apresentados nas Tabelas 41 e 42, observando-se uma variaçăo dentro da faixa descrita por ${ }^{3}$ GALLO et alii (1974) para as gramineas, forrageiras cultivadas em Såo Paulo.

A Tabela 45 da análise de variância, mostrou efeitos significativos para a adubaçăo fosfatada no primeiro corte, para a aplicaçå de micronutrientes no primeiro e segundo cortes, para a calagem no primeiro, segundo e quarto cortes, e das interaçőes fósfoṛo x calagem no primeiro e segundo cortes e micronutrientes $x$ calagem no segundo corte. Desdobrạndo-se a interaçăo fósforo $\times$ calagem verificou-se no primeiro e segundo cortes, como era esperado que a calagem reduziu significativamente os teores de Mn em presença dos niveis de 100 e 200 ppm de P. Por outro lado, a adubação fosfatada na ausência de calagem no primeiro 
corte Incrementou Iineármente os teores de Mn (Tabelas 38 e 42), enquanto que na presença de calagem a adubaçăo fos fatada teve efeito quadrático sobre os teores de Mn. Já no segundo corte, os efeitos.da adubaçăo fosfatada na ausência ou na presença de calagem, mostraram-se quadráticos conforme equações de regressão apresentadas na Tabela 38.

Examinando-se a interação micronutriente $x$ calagem no segundo corte, verificou-se que, na ausência de calagem, a não aplicação de micronutriente resultou em teores mais elevados de Mn, porém na presença de calagem não houve diferenças entre os teores de Mn na parte aérea do capim coloniåo mediante a aplicaçåo ou não de micronutrientes (Tabela 41).

No quarto corte, a calagem produziu o efeito espérado, diminuindo a disponibilidade do manganês,' reduziu sua absorçåo (Tabela 42).

\section{Ferro}

s

Os teores de $\mathrm{Fe}$ na matéria seca da parte aérea do capim coloniåo en funçăo da calagem e da adubaçăo fosfatada såo apresentados na Tabela 42. O valor minimo encontrado foi de $78 \mathrm{ppm}$ de Fe, na matéria seca do terceiro corte do coloniăo adubado com 200 ppm de $P$ e na ausência de calagem, e o máximo de 200 ppm na matéria seca do segundo corte. As médias obtidas no primeiro, segundo e quarto cortes estão acima do nivel ideal de 100 ppm descrito por EPSTEIN (1975) para as plantas em geral.

A análise de variância (Tabela 45)... mostrou efeito significativo para a adubaçåo fosfatada no segundo e 
quarto cortes e para a aplicação de micronutirientes no primeiro corte. Verificou-se, no primeiro corte, que os teores de Fe obtidos na ausência de micronutrientes foram superiores aos encontrados com a aplicação de micronutriente.

\section{Molibdênio}

Na Tabela 46 são mostrados os resultados da análise de variância para os conteúdos de molibdênio na parte aérea do capim colonião. Foram observados efeitos signifi cativos $(P \leqslant 0,01)$ da adubação fosfatada (no primeiro, terceiro e quarto cortes) da aplicaçåo de micronutrientes e da calagem (nos quatro cortes), e das interaçöes fósforo $x$ micronutrientes e micronutrientes $x$ calagem (nos quatro cortés) e fósforo $x$ calagem (no terceiro e quarto cortes).

O desdobramento da interação fósforo $x$ micronutriente demonstrou efeito significativo dos niveis de fósforo, sobre os conteúdos de Mo na parte aérea do capim coloniăo (exceto no segundo corte) na presença de aplicaçăo de micronutrientes (incluindo o molibdênio). Entretanto, na ausência de aplicação de micronutrientes, não foram significativos os efeitos dos níveis de fósforo sobre os teores de molibdênio na parte aérea dọ capim coloniåo (Tabela 46 e 47). As equações de regressão representativas das variações nos teores de molibdênio com a fertilização fosfatada são aprəsentadas na Tabela 48. Pode-se observar, na pre sença de micronutrientes, que o emprego de niveis de fósforo mostrou efeitos quadráticos no primeiro, terceiro e quarto. cortes e, reduções lineares nos conteúdos de molibdênio no segundo corte. 
Os conteúdos de molibdênio oscilaram

entre 0,08 a 5,1 ppm na matéria seca da parte aérea do capim coloniåo. Alguns autores como OSTROWSKI et alii (1978), KABATAPENDIAS \& PENDIAS (1984) relatam que teores na faixa de 0,5 a $1,0 \mathrm{ppm}$ de Mo como adequados para o crescimento :i: das plantas. Observa-se que, na ausência de aplicaçåo de micronu trientes, os teores de molibdênio na parte aérea do coloniåo estiveram abaixo do nivel considerado adequado. Já, com a aplicaçåo de micronutrientes (incluindo o Mo) verificou-se significativos aumentos nos conteúdos de Mo nos quatro cortes em todos os niveis de adubaçåo fosfatada (Tabela 50). '

0 desdobramento da interaçăo fósforo $x$ calagem revelou que a calagem teve efeito significativo e positivo incrementando os conteúdos de molibdênio na matéria seca da parte aérea do capim coloniăo no terceiro e quarto cortes em todos os niveis de adubaçăo fosfatada (Tabela 49). Por ou tro lado, a adubaçăo fosfatada com calagem resultaram incrementos (terceiro corte) ou reduçס̃es (quarto corte) sobre os conteúdos de molibdênio, que obedeceram efeitos quadráticos, cujas equações de regressão são mostrados na Tabela 48.

Na ausência da' calagem, a aplicaçăo de niveis de fósforo nåo alterou significativamente os conteúdos de mo libdênio na parte aérea do capim coloniăo.

Nessas condições, a.fixação do molibdênio pelos óxidos de ferro e, de aluminio e outros minerais de argi la podem explicar esse fato. A calagem elevando o pH afetou a disponibilidade de Mo para o coloniåo. A influência do pH do solo na disponibilidade desse elemento para as culturas pode ser entendida conforme relatada por LINDSAY (1972), que estimando a solubilidade do $\mathrm{MoO}_{4}^{2-}$ a partir da reaçåo: 


$$
\begin{aligned}
& \mathrm{MoO}_{4}^{2-}+\text { solo } \leftrightarrow \text { Solo }-\mathrm{Mo}_{4}+2 \mathrm{H}_{\mathrm{H}}^{-} \\
& \text {encontrou a relaçåo: }\left(\mathrm{MoO}_{4}^{2-}\right)=10^{-20,5} /\left(\mathrm{H}^{+}\right)^{2}
\end{aligned}
$$

mostrando que a concentraçăo de molibdato aumenta cem vezes para cada unidade de aumento do $\mathrm{pH}$.

A interaçåo entre Mo-P é frequentemente relata da pela açăo do $\mathrm{H}_{2} \mathrm{PO}_{4}^{-}$• aumentando a absorção do molibdato, através da formação externa do fosfomolibdato mais solúvel na membrana, pelo deslocamento do $\mathrm{MoO}_{4}^{-2}$ pelo $\mathrm{H}_{2} \mathrm{PO}_{4}^{-}$dos sitios de absorção sendo entạo utịizado (MALAVOLTA, 1980). En tretanto, os efeitos descritos para os fertilizantes fosfatados na disponibilidade do Mo săo contraditórios, de um módo geral os superfosfatos contendo $\mathrm{so}_{4}^{2-}$ reduzem a absorção de Mo, já os superfosfatos concentrados aumentam sua absorçạoo (ADAMS, 1980). Essas interaçőes são variáveis e governadas por diversos fatores do solo e, também, relacionadas com os processos metabólicos da planta.

A Tabela 46 mostra a variação nos conteúdos de molibdênio na parte aérea do capim coloniăo em funçăo da aplicação ou não dẹ calagem na presença ou na ausência de micronutrientes. 0 desdobramento da interaçåo calagem $x$ micronutrientes evidenciou que tanto na ausência como na presença de calagem, o emprego de micronutrientes (incluindo o molibdênio) correspondem a incrementos significativos nos conteúdos de Mo do capim colonião nos quatro cortes, sendo esses incrementos mais elevados no primeiro corte (Tabela 51). Examinando-se os efeitos da calagem, observou-se, que com a utilização dos micronutrientes, a correção de acidez resultou em maióres acumulaçőes de Mo na parte aérea do capim coloniåo (Tabela 51 ) em comparaçăo ao tratamento onde o calcário não foi utilizado. Esses incrementos são de 
correntes da maior disponibilidade do Mo do solo ou do aplicado mediante a prática da calagem. Outro fato que chama a atenção é que no quarto corte mesmo na ausência de utilização de micronutrientes, a calagem incrementou significativamente os conteúdos de Mo na matéria seca da parte aérea do capim coloniåo.

A correlação simples entre as produções de matéria seca do capim colonião e os teores de molibdênio na ma téria seca para os quatro cortes nåo foram significativos.

\section{Cobalto}

A análise de variância (Tábela 46) para os con teúdos de cobalto na parte aérea do capim coloniåo, evidenciou efeitos significativos da aplicaçåo de fósforo e das interaçőes fósforo $x$ calagem e fósforo $x$ micronutrientes (no segundo e quarto cortes), de micronutrientes, da calagem, e da interação micronutriente $x$ calagem (no segundo, terceiro e quarto cortes). Para os conteúdos de cobalto no primeiro corte não houve significância para nenhum dos fatores estuda dos.

0 desdobramento da interação calagem $x$ micronu trientes revelou efeito significativo e positivo da aplicaçăo de micronutrientes sobre os teores de cobalto na parte aérea do capim colonião no segundo, terceiro e quarto cortes, tanto na presença como na ausência da calagem (Tabela $51)$.

Os conteúdos de cobalto, obtidos no terceiro e quarto cortes, na ausência de aplicação de micronutrientes, foram bastante baixos, encontrando-se abaixo do Iimiar 
de carência descrita por JARD́IM et alii (1962) que é de 0,05 ppm de Co. Com a utilização de micronutrientes (incluindo o cobalto) como era esperado houve significativos incrementos nos conteúdos de Co.' Porém já do terceiro corte em dianté os conteúdos de cobalto foram menores mesmo com a adiçăo desse elemento juntamente com os outros micronutrientes. Es se fato pode parcialmente ser explicado pela elevada extraçăo desse micronutriente nos cortes iniciais.

Examinando-se os efeitos da calagem, verificou -se que na ausência de aplicação de micronutrientes a calagem não teve influência significativa sobre os conteưdos de cobalto, porém mediante o emprego de microniutrientes seus efeitos foram significativos. De tal forma que no segundo corte a calagem elevou expresisivamente os conteúdos de cobal to, entretanto no terceiro e quarto cortes a calagem proporcionou uma redução nos teores de cobalto (Tabela 51). Esses resultados obtidos no terceiro e quarto cortes vem corroborar com os encontrados por MITCHELL (1962) que também observou reduçőes nos conteúdos de cobalto mediante a aplicaçăo da calagem. Esse fato é decorrente da diminuiçăo da disponibilidade do cobalto devido as elevaçðes do pH pela calagem.

Os conteúdos de cobalto no capim coloniåo, em função da aplicação da calagem e de micronutrientes, variaram entre 0,01 a 1,67 ppm. Conforme pode ser observado na Ta bela 51 , os menores teores de cobalto foram encontrados a partir do segundo corte na ausência de aplicação de micronutrientes. Com conteúdos de cobalto inferiores a $0,07 \mathrm{ppm}$. 0 coloniăo é considerado deficiente (PEREIRA, 1971). JARDIM et alii (1962), PEREIRA et alii (1971) e GALLO et alii (1974) também obtiveram baixos conteúdos de cobalto em pastagens na 
turais de capim coloniåo. A adição de cobalto chegou a incrementar seus conteúdos no segundo corte a valores superiores aos descritos por KABATA-PENDIAS \& PENDIAS (1984).

Também foi significativa a interaçåo fósforo $x$ calagem para o.s dados do segundo e do quarto cortes. Desdobrando-se essa interação observou-se que no segundoll corte, a calagem teve efeito significativo aumentando os conteúdos de cobalto nos niveis de fósforo de 20 e 200 ppm. Entretanto no quarto corte, apenas no nivelimais baixo de fósforo (20 ppm) à não aplicação de calagem correspondeu maiores teores de cobalto, enquanto que nos niveis mais elevados de adubação fosfatada a calagem năo teve efeito significativos (Tabëla 49). Por outro lädo a adubação fosfatada mostrou na ausệncia ou na presença de calagem. efeitos quadráticos no seguindo e no quarto cortes (Tabela 48).

0 desdobramento da interação fósforo $x$ micronu triente evidenciou que a adubaçåo fósfatada nåo tem efeito significativo na ausência de aplicação de micronutrientes

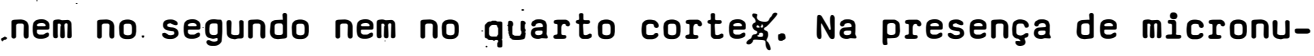
trientes, a adubaçåo fosfatada mostrou efeito quadrático sobre os conteúdos de cobalto conforme mostram os resultados das análises de regressão apresentados nas Tabelas 50 e equa çőes de regressão Tabela 48. A aplicação de micronutrientes, incluindo o cobalto, proporcionou expressivas elevações sobre os conteúdos de cobalto na matéria seca da parte aérea do capim coloniåo no segundo e quarto cortes em todos os niveis de adubação fosfatada.

A correlação simples entre os teores de cobalto na matéria seca do capim coloniåo nos quatro cortes com as produções de matéria seca não foi significativa. 
4.3.2. Soja perene cultivada no solo Latossolo VermelhoEscuro álico (LEa)

4.3.2.1. Teores de Nutrientes

Os teores de macronutrientes na parte aérea da soja perene em dois cortes săo apresentados na Tabela $5 \dot{3}$.

A análise de variância (Tabela 52) revelou efeito significativo da calagem (ambos cortes) e da interaçăo calagem $x$ cobalto no primeiro corte sobre os teores de nitrogênio.

As porcentagens de nitrogênio, na presença de calagem, foram superiores.as encontradas por SOUTO \& DǑBEREI NER (1969) que obtiveram de $2,04^{\circ}$ a $2,25 \%$ ou aos $2,18 \%$ obtidos por JONES et alii (1970). A porcentagem de nitrogênio na. párte aérea da planta, por ocasiăo do primeiro corte (Tabela 5 3) mostrou sensivel reduçáo com a aplicaçáo de niveis de calagem. Essa reduçăo foi simultânea a aumentos na kroduçăo de matéria.seca da parte aérea, portanto a reduçåo nos teores de nitrogênio possivelmente se deve a diluiçăo do elemen to na planta.

Já no segundo corte pode-se observar que a calagem resultou em acréscimos lineares e significativos (Tabe las 54 e 55) nos teores de nitrogênio da parte aérea no segundo corte. Esse resultado corrobora com os obtidos por TEITZEL \& BRUCE (1973) e. SOARES \& VARGAS (1974). Os valores porcentuais desse elemento na parte aérea, mesmo com os aumentos na produçăo de matéria seca, foram mais altos nos niveis mais elevados de calagem. Aumentos similares, devido à calagem, foram constatados com soja perene por JONES et alii e por FRANÇA et alii (1973). 
0 desdobramento da interação calagem $\times$ cobalto evidenciou que a calagem só teve efeito significativo na ausência de aplicação de cobalto, reduzindo linearmente as por centagens de nitrogênio (Tabelas 52 e 55) principalmente devido ao efeito de diluição verificado devido ao maior crescimento com a aplicaçåo de níveis de calagem. A aplicação de cobalto teve efeito significativo e depressivo sobre os teores de nitrogênio na matéria seca da parte aérea apenas na ausência de aplicaçåo de calcário. Trabalhos realizados por MITCHELL (1962) e por MEKENZIE (1975), evidenciaram que, quanto menor os valores do $\mathrm{pH}$, maior a disponibilidade do cobalto, no solo. Dessa maneira o cobalto adicionado mais o originário do solo, mediante a não utilização da calagem, foi suficiente para reduzir os teores de nitrogênio na parte aérea da soja perene (Tabèla 55).

TAYLOR $\dot{\alpha}$ MCKENZIE (1966) constataram que cerca de $80 \%$ do Co total no solo encontra-se associado aos ${ }^{\&}$ óxidos de $\mathrm{Mn}$; que no solo estudado apreșentam alta disponibilidade, confirmado pelos elevados teores de Mn encontrados na parte aérea da soja perene na ausência de calagem. Mediante a utilização de niveis de calagem $e$, consequentes reduçס̃es nas disponibilidades do cobalto, os efeitos da utilizaçăo do cobalto foram nåo significativos, embora mostrassem tendência de elevar os conteúdos de $\mathrm{N}$ na parte aérea da soja perene (Tabela 55).

Na Tabela 52 e 53 pode-se observar os efeitos dos tratamentos sobre os teores de fósforo, potássio, cálcio, magnésio e enxofre. A calagem teve efeito significativo sobre os teores de potássio, cálcio e magnésio, em ambos cor tes, e sobre os teores de enxofre no segundo corte. As inte- 
raçб̄es calagem $\times$ cobalto também mostraram-se significativas em relação aos conteúdos de enxofre no primeiro corte. As demais interaçס̃es, bem como as aplicações de molibdênio-e de cobalto não demonstraram significância sobre as concentrações desses macronutrientes. De um modo geral, verificou-se que as concentrações de fósforo, potássio, cálcio, magnésio e enxofre eståo dentro dos valores normalmente reportados na literatura (FRANÇA et alii, 1973; WERNER et alii, i975a).

As concentraçőes de fósforo nåo foram afetadas com os diferentes tratamentos, sendo de um modogeral superiores as obtidas por MONTEIRO (1980). para essa leguminosa forrage $\underline{\underline{i}}$ ra.

As concentraçőes de potássio na soja perene de cresceram significativamente, em ambos os cortes, em funçăo da calagem (Tabela 53), reduçőes nos teores de potássịo devido à calagem são relatados por MIRANDA (1979).

Esses decréscimos nos teores de potássio seriam resultado ởe uma diluição desse nutriente no interior da planta em-consequência dos aumentos de produção de matéria seca com a aplica-s çåo da calagem.

O teor de cálcio na parte aérea da soja perene cultivada na ausênçia de calagem, no segundo corte, apresentou um efeito de concentração do elemento. Quando se conside ra os teores nas plahtas cultivadas em presença de calagem, verifica-se que houve decréscimos significativos e lineares (Tabela 53) no segundo corte. Năo é comum observar-se esse tipo de redução, porém sendo ela de baixa magnitude, enquan to que os aumentos na produção de matéria seca foram muito mais expressivos, a quantidade de cálcio absorvida, certamente, foi maior com a elevação da calagem. 
Os teores de magnésio na parte aérea da soja perene no primeiro corte sofreram acréscimos significativos e lineares, enquanto que no segundo corte. mostrou variações quadrática em relação à calagem.

Na Tabela 54 pode ser observado as equações de regressão para as variações nos teores de potássio, cálcio, magnésio e enxofre em funçăo dos níveis de calagem.

o emprego de niveis de calagem resultou em reduçőes nos teores de enxofre revelando comportamento quadrá tico no. primeiro corte, e linear no segundo corte (Tabelas 52 e 53). 0 desdobramento da interação calagem $\times$ cobalto evi denciou que, na ausência da calagem, a aplicaçåo de cobalto resultou em maiores teores de enxofre na parte aérea do primeiro corte da soja perene, entretanto mediante o emprego de calcário a utilização ou não de cobalto não afetou significa tivamente os teores de enxofre (Tabela 55). Por outro lado, na ausência de cobalto, a calagem nåo alterou os teớzes de enxofre. Porém, com o emprego de cobalto, a calagem... diminuiv quadraticamente os teores de enxofre (Tabela 17).

Os teores de boro e ferro (no segundo corte), cobre (no primeiro corte), manganês e zinco (em ambos cortes) na soja perene mostraram significativos decréscimos com a elevaçăo das doses de calcário (Tabelas 56 e 57). Esses ré sultados concordam com o relatado por LINDSAY (1972) em rela ção a diminuição da disponibilidade desses . micronutrientes pela calagem, e também com os resultados obtidos por JONES et alii (1970) e MIRANDA (1979). 
Com relaçăo aos teores de manganês na soja perene cultivada em ausência de calagem, verificaram-se concen traçð̋es em torno de 550 ppm de manganês. De acordo com Andrew, citado por JONES \& FREITAS (1970) uma . concentração maior que $450 \mathrm{ppm}$ de manganês na soja perene deve resultar em toxidez do elemento à planta. Realmente, cerca de 15 dias após a germinação das plantas, as primeiras folhas das plântulas de soja perene mostraram clorose nos seus bordos, na ausência da calagem. Essa clorose foi se acentuando, tornando-se bem nitida nos bordos e avançando entre as nervuras. Concomitantemente surgiram pontos necróticos nas áreas cioróticas, e as plantas na ausência de calágem, aproximadamente 30 dias após a semeadura já apresentavam desenvolvimento bem ménor que nos vasos cọm calagem. Esses sintomas săo idêñ ticos aos apresentados por SOUTO \& DǑBEREINER (1969),. WERNER et alii (1975a) e MONTEIRO (1980) para a toxidez de manganês em soja perene.

De acordo com MALAYOLTA et alii (1989) os teores de cobre, ferro e zinco são considerados adequados para o cultivo da soja perene, enquanto que os teores de boro e de manganês (na ausência ou no nivel $\vec{l}$ de calagem) são consi derados altos.

Na Tabela 54 săo apresentadas as equações de regressăo que evidenciam decréscimos lineares para os teores de boro ( 20 corte), cobre (10 corte) e zinco (10 corte) com a aplicaçåo de niveis de calagem, enquanto que sobre os conteúdos de manganês (ambos cortes) e zinco ( 20 corte) as redu çőes decorrentes da aplicaçăo de calcário obedeceram efeitos quadráticos.

A interaçåo calagem $\times$ cobalto, sobre os teores 
de ferro ( 20 corte), mostrou-se significativa (Tabelas 55 e 56). Na ausência de calagem, a aplicação de cobalto resultou em teores mais elevados de ferro, porém mediante a prática da calagem o emprego de cobbalto năo afetou significativamente os conteúdos de ferro na parte aérea da soja perene. Por outro lado, os conteúdos de. ferro, tanto na presença como na ausência de aplicaçăo de cobalto diminuiram com a aplicaçăo de niveis de calagem, obedecendo efeitos lineares (na presen ça de cobalto) e quadráticos (na ausência de cobalto).

4.3.3. Soja perene cultivada no solo Latossolo Vermelho Amarelo distrófico (LVd)

4.3.3.1. Teores de Nutrientes

A. análise de variância (Tabela 58) para os teo res de macronutrientes na parte aéréa da soja perene, cultivada no solo LVd, resultou em efeitos significativos da cala gem sobre os conteưdos de $\mathrm{N}, \mathrm{K}, \mathrm{C}$, $\mathrm{Mg}$ e $\mathrm{S}$ (em ambos cortes) e P (no primeiro corte) enquanto que o emprego de Mo $e$ de Co e as demais interaçōes não mostraram efeitos significativos.

Os teores destes macronutrientes na parte aérea da soja perene săo apreséntados na Tabela LVIII.

Os teores de nitrogênio $(2,72 \% \mathrm{~N})$ no primeiro corte, na ausência de calagem foram mais elevados provavelmente devido ao efeito de concentração desse nutriente, uma vez que a produçăo de matéria seca da leguminosa foi significativamente menor nesse tratamento. Com a elevaçåo dos niveis de calagem as produçōes de matéria seca foram aumenta- 
dos, resultando em reduções nos teores de nitrogênio possivelmente devido a diluição do elemento na planta.

$$
\text { No segundo corte, a aplicação da dose ' mais }
$$

elevada de calcário incrementou significativamente a concentraçåo de $N$ na parte aérea da soja perene (Tabela 58). Esse aumento parece estar associado a maior fixação de $\mathrm{N}$. Respos tas a calagem por leguminosas tropicais estimulando à fixação de N também foram observados por MUNNS et alii (1977). 2

Os conteúdos de fósforo (primeiro corte), potássio è enxofre (em ambos cortes) foram mais elevados na au sência da calagem. Com o emprego dos nịveis de calagem os teo res desses nutrientes diminuiram. Diminuição na porcentagem de fósforo em soja perene, quarido comparado o tratamento sem calagem e sem cálcio com o tratamento completo foi observado pór MIRANDA (1979), enquanto diminuições nos teores de potássio devido à calagem são relatados por JONES \& FREITAS (1970) e MIRANDA (1979). Tais reduçð̋es seriam resultał̧tes de uma diluição dos nutrientes no interior da planta.

Os teores de cálcio na parte aérea da soja perene no primeiro corte foram crescentes com a elevação do nivel de calagem. Já no segundo corte para a soja perene cul tivada em ausência de calagem, ou no nivel 1 de calagem ( $T a-$ bela 58) mostrou um efeito de concentração do elemento. Resultados semelhantes foram descrito por FRANÇA et alii (1973) e MIRANDA (1979).

A porcentagem de magnésio na soja perene sofreu acréscimos significativos com a calagem, sendo lineares no primeiro corte e quadrático no segundo corte. Tais acréscimos são esperados uma vez que o calcário calcinado utilizado é fonte de Mg para essa leguminosa. 
Os teores de enxofre na parte aérea de soja pé rene foram mais elevados no nivel 0 de calagem, provavelmente devido ao efeito de concentraçăo desse elemento pois a produçåo de matéria seca dessa leguminosa foi significativamente menor nesse tratamento.

De um modo geral pode-se verificar que as concentraçōes de $\mathrm{N}, \mathrm{P}, \mathrm{K}, \mathrm{Ca}, \mathrm{Mg} \mathrm{e} \mathrm{S}$ eståo dentro dos valores normalmente apresentados na literatura (JONES \& FREITAS, 1970 e WERNER et alii, 1975a).

Os teores de boro, cobre, ferro, manganês e zinco nos materiais colhidos da soja perene (Tabela 59) sofreram significativos decréscimos com as doses de calagem empregadas (Tabela 60). Esses decréscimos săo devido a reduद̧ăo nä disponibilidade desses micronutrientes pela calagem, conforme descrito por LINDSAY (1972).

$\mathrm{Na}$ ausência de calagem os teores de boro, manganês e zinco (em ambos cortes) e ferro no segundo cởrte săo considerados altos (Tabela 59). Os teores de manganês, no primeiro e no segundo cortes chegaram, respectivamente a 677 e 868 ppm no nivel o de calagem. Segundo ANDREW \& . HEGARTY (1969) concentração de manganês superior a 560 ppm em soja perene deve resultar em toxidez do elemento a planta.

Realmente, durante a conduçăo do experimento, verificou-se, no estádio iniçial de crescimento e no ćrescimento da rebrota, uma clorose nitida nos bordos e nervuras das primeiras folhas, surgindo concomitantemente manchas necróticas. Sintomas semelhantes aos descritos por MONTEIRO (1980) e por outros pesquisadores para essa leguminosa forrageira como toxidez de manganês. 
A aplicação do nivel 1 de calagem $(0,43$ t. de calcário por hectare) resultou em diminuiçőes nos teores de manganês abaixo dos níveis estabelecidos como tóxioos. nos trabalhos de ANDREW \& HEGARTY (1969). Embora nesse nivel de calagem esses conteúdos se mantiveram relativamente altos. No tratamento que recebeu a maior dose de calcário $(1,60 \mathrm{t}$ de calcário por hectare) os teores de manganês estiveram entre 80 e 120 ppm. (Tabela 59).

SOUTO \& DǑBEREINER (1969) relataram que a toxidez de manganês afetaria mais o desenvolvimento da nodulação que o da planta em si. A correlaçăo dos dados dos teores de manganês no primeiro e no ségundo cortes da soja perene com o peso de nódulos mostrou-se significativa e negativa tanto no primeiro corte $(r=-0,92 * *)$ como no segundo . corte ( $r$ = $\left.-0,94^{*}\right)$. Reșsalta-se também que o excesso de manganès. reduziu as produções de matéria seca dessa leguminosa (Tabela 19). De acordo com JACKSON (1967) é dificil 's a separaçăo entre os fatores que afetam o crescimento e/ou a nodulação, entretanto diante dos dados obtidos nota-se que a calagem agiu beneficamente eliminando a toxidez de manganês.

$\mathrm{Na}$ Tabela 21 pode-se observar as equaçס̃es de regressão representativas dos efeitos da calagem sobre os teores de macronutrientes e de micronutrientes.

Verificou-se, no primeiro corte, que a aplicação de cobalto correspondeu a teores de Mn de 338 ppm, significativamente inferiores aos obtidos com a não aplicaçăo de cobalto 364 ppm de Mn. Entre as prováveis explicações para esses fatos, a literatura relata que há um antagonismo entre Co e Mn, resultante das condiçóes de acidez do solo, 
geralmente baseado numa troca do $\mathrm{Co}^{2+} \operatorname{com} \mathrm{Mn}^{2+}$ em $\mathrm{pH}$ baixo. No solo a adsorção do Co pelos óxidos de mangànês aumenta grandemente com o pH, reduzindo evidentemente os efeitos antagônicos com a calagem (KABATA-PENDIAS \& PENDIAS, 1984).

4.3.4. Centrosema cultivada no solo Latossolo Vermelho-Es curo álico (LEa)

4.3.4.1. Teores de Nutrientes

Na Tabela 61 såo apresentados os resultados da análise de variância para os efeitos da calagem, molibdênio, cobalto e interaçåo entre esses fatores sobre os conteúdos dos macronutrientes nitrogênio, fósforo; potássio, cálcio, magnésio e enxofre na parte aérea da centrosema cultivada no solo LEa. Observou-se que a calagem alterou significativamente os teores de nitrogênio, cálcio, magnésio e enxofre da centrosema. A porcentagem de nitrogênio sofreu ăumentos significativos, como resultado da aplicaçăo de doses de calcário, sendo linear no primeiro corte e quadrático no segundo corte (Tabela 62). Esses resultados foram similares aos obtidos por SOARES \& VARGAS (1974) e WERNER \& MATTOS (1972).. Essa resposta à calagem pela centrosema evidencia um estímulo a fixação de $N$, como mostram os aumentos na produção de matéria seca da parte aérea e nos teores de $\mathrm{N}$ (Tabelas 22 e 62).

A utilização do molibdênio resultou em efeitos positivos, elevando os conteúdos de nitrogênio na parte aérea do segundo corte da centrosema. Tais efeitos são decor rentes do papel do Mo no processo de fixaçåo.

os conteúdos de nitrogênio na parte aérea (Ta- 
bela 62) são superiores aos encontrados por MONTEIRO (1980) e esiåo na mesma faixa verificada por WERNER \& MATTOS (1972). Os teores de cálcio e magnésio, em ambos cortes, foram aumentados a mèdida que se elevou o nivel de cala gem (Tabela 62). Aumentos nessas variáveis têm sido constata dos pOr WERNER \& MATTOS (197̣2), JONES \& FREITAS (1970) mediante a aplicaçåo de calcário.

Os teores de cálcio e de magnésio na parte aérea da centrosema, no material colhido no segundo corte, foram expressivamente inferiores aos obtidos no primeiro corte, para.os mesmos niveis de calagem. Esses resultados evidenciam que o cultivo contínuo dessa leguminosa forrageira nesse solo, possivelmente, seriam acompanhados por limitaçőes nutricionais tanto para o crescimento como para fixaçăo simbiótica de nitrogênio:

Os conteúdos de enxofre, no primeiro corte, au mentaram linearmente com a calagem. Possivelmente, o uso do calcário tenha favorecido a mineralizaçāo do enxofre orgânico e, com o aumento do pH pode ter ocorrido uma : liberação, do $\mathrm{SO}_{4}^{-2}$ adsorvido aọs colóides do solo. Os teores de enxofre obtidos na parte aérea da centrosema eståo numa faixa de valores semelhantes aos obtidos por GALLO et alii (1974) e JONES \& QUUAGLIATO (1970).

Ao se analisar os teores de boro, cobre, ferro, manganês e zinco na parte aérea da centrosema, verificou-se que a calagem influiu șignificativamente sobre os teores des ses micronutrientes, com exceção aos teores de cobre no primeiro corte e ferro em ambos cortes (Tabela 63). Foi também significativa a interação calagem $\times$ molibdênio sobre os teores de zinco no primeiro corte. 
A aplicação de calcário diminuiu os teores de boro e ferro (segundo corte), cobre (primeiro corte), manganês e zinco (ambos cortes). na parte aérea da centrosema cultivada no solo LEa, conforme mostram os dados apresentados na Tabela 64. As equações de regressão representativas das variaçőes dos teores desses. nutrientes em funçăo da calagem podem ser observadas na Tabela 24. A literatura relata reduçăo na disponibilidade desses micronutrientes com a calagem (LINDSAY, 1972 E JONES et alii, 1970). As concentrações de boro, cobre, ferro e zinco na parte aérea da centrosema são consideradas não limitantes ao desenvolvimento da centrosema e eståo dentro da faixa encontrada por MONTEIRO (1980) para essa leguminosa.

0 desdobramento da interação calagem $x$ molibdê nio revelou; para os teores de zinco no primeiro corté, que, apenas na ausência de calagem, à aplicação de molibdênio cor respondeu teores mais elevados de zinco que a năo aplicaçăo de Mo. Na literatura disponivel não foi encontrada explicaçăo aparente para esse fato. A calagem, na presença ou não de-molibdênio, diminuiu linearmente os teores de zinco na parte aérea da centrosema (Tabela 64 e 65), devido a reduçåo na disponibilidade desse nutriente.

4.3.5. Centrosema cultivada no solo Latossolo VermelhoAmarelo distrófico (LVd)

4.3.5.1. Teores de Nutrientes

$\mathrm{Na}$ Tab̄ela 66 săo apresentados os dados da análise de variância para os teores de macronutrientes em centrosema cultivada no solo LVd. A calagem teve efeito signi- 
ficativo sobre os conteúdos de nitrogênio, mágnésio, enxofre, em ambos cortes e sobre os teores de cálcio no primeiro corte (Tabela 67). A interação calagem $x$ molibdênio mostrou efeito significativo sobre os conteúdos de $N$ na parte aérea da centrosema no segundo corte.

Os conteúdos de nitrogênio ná parte aérea da centrosema, de um modo geral foram mais baixos na ausência da calagem, sendo incrementada com a aplicaçåo de calcário. No segundo corte, observaram-sé conteúdos de $\mathrm{N}$ na parte aérea da centrosema superiores aos encontrados no primeịro cor te (Tabela 67):

O desdobramento da interação calagem $x$ molibde nio revelou que o emprego do molibdênio incrementóu os teores de $N$, tanto na ausência como no nivel 1 de calagem, porém não teve efeito significativo no nivel 2 de calagem (Tabela 68). Sem a utilização de molibdênio a calagem teve efe to quadrático sobre os teores de $N$, enquanto que na presença de molibdênio os incrementos foram lineares e positivos. É sabido que entre outros fatores a disponibilidade do molibdê nio no solo depende do seu nivel de acidez. Dessa maneîra, - emprego do nivel 2 de calcário, melhorando a disponibilida de desse micronutriente no solo, proporcionou condições satisfatórias para que a centirosema acumulasse $N$ na parte aérea de maneira similar, tanto-na presença como na ausência de molibdênio.

Efeitos benéficos do molibdênio na porcentagem de nitrogênio são resultantes da participação desse micronu triente no processo de fixação biológica, conforme descrito POI ANDERSON (1956a) e ANDREW (1962). De acordo com NICHOLAS (1975) o molibdênio participa ativamente como componen- 
te da nitrogenase, enzima responsável pela fixação biológica do $\mathrm{N}_{2}$. Ocorrendo limitaçőes no suprimento de. Mo haverá uma redução na sintese da enzima, refletindo-se em menor atividade e consequentemente, numa diminuição da fixação biológica de $\mathrm{N}_{2}$.

Desdobrando-se a interação ca lagem $x$ cobalto observa-se aumentos lineares e positivos sobre os teores de nitrogênio, devido a calagem tanto na presença como na ausência de cobalto. Verificou-se que o emprego de cobalto, na ausência da calagem, resultoù em menores teores de nitrogênio na parte aérea da centrosema, no segundo corte, porém em presença da calagem a aplicação de cobalto não teve efeito significativo sobre os conteúdos de nitrógênio (Tabela 68). Na Tabela 69 são apresentadas as equações de regressão correspondentes aos efeitos lineares e positivos da calagem, na presença não de aplicação de cobalto, sobre os teores de nitrogênio.

Os teores de cálcio (primeiro corte), magnésio e enxofre (ambos cortes) foram significativamente afetados pela aplicação de calcário (Tabelas 66 e 67). Aumentos nos conteúdos de cálcio (primeiro corte) da centrosema mediante a calagem também foram verificados : :por ANDREW \& NORRIS (1961) e WERNER \& MATTOS (1972). Também, os teores de magnésio em ambos cortes sofreram acréscimos com a calagem, resul tados esses similares aos encontrados por JONES \& FREITAS (1970). Esses aumentos são esperados pois o calcário é fonte de Ca e de Mg.

Com relação aos conteúdos de enxófre observou -se no primeiro corte, aumentos devido a aplicação de calcário. Tais incrementos, possivelmente tenham sido decorrentes 
da mineralizaçåo do enxofre orgânico. Já, no segundo corte; a aplicação de níveis de calcário resultou em diminuiçōes sobre os teores de enxofre que obedeceram efeitos quadráticos, tais reduçōes podem ser atribuídas aos efeitos de diluí çăo em virtude do maior crescimento mediante a aplicaçăo de calcário. A Tabela 27 mostra as equaçőes de regressão para os niveis de calagem sobre os conteúdos de Ca, Mg e S.

A aplicação de cobalto resultou em maiores teo res de cálcio (segundo corte) na parte aérea da centrosema $\mathrm{Na}$ literatura consultada esse. fato nåo foi mencionado.

Sobre os conteúdos de fósforo e de potássio em ambos cortes, nåo foram observadas influências significativas da calagem, das aplicações de molibdênio, e de cobalto e nem" das interaçðes.

Os resultados das análises de variåncias e os teores médios de boro, cobre, ferro, manganês e zinco em cen trosema cultivada no s.olo LVd, com a elevaçăo das dơses de calcário săo apresentados nas Taḅelas 70 e 71.

Os teores de cobre (primeiro corte), manganês e de zinco (ambos cortes) mosträram decréscimos com a eleva çăo das doses de calcário, tais resultados săo similares aos obtidos por JONES et alii (1970) e concordam com o relatado por LINDSAY (1972) que as disponibilidades desses elementos são diminuidas com o emprego do calcário em solos ácidos.

Os teores de manganês na ausência de. calaggem estiveram acima de 500 ppm (Tabela 71). DÖBEREINER \& ARONOVICH (1966) mencionam toxidez desse elemento em centrosema quando os teores situam-se ligeiramente acima de 300 ppm. An drew, citado por JONES \& FREITAS (1970) apresenta como nivel critico para toxidez de manganês uma concentração de 730 ppm 
do elemento. Embora, no presente experimento, aparentemente nåo se notou qualquer sintoma de toxidez de manganês, supőe-se que o alto teor observado esteja relacionado aos efei tós prejudiciais a nodulação e fixaçåo biológica do $N_{2}$ conforme pode ser observado nas Tabelas 26,67 e 71. .

Os teores de boro na parte aérea (Tabela 71) foi significativamente mais elevado nos niveis 1 e 2 de cala gem, resultando em efeito quadrático no primeiro corte e linear no segundo corte.

Os teores de cobre e de ferro na parte aérea da centrosema, no segundo corte, nåo variaram significativamente com os níveis da calagem empregados. 'Porém, no primeiro corte, a calagem incrementou linearmente os conteúdos de ferio, possivelmente por diminuir a disponibilidade do Mn que inibe conpetitivamente a absorção de ferro.

4.3.6. Galactia cultivada no solo Latossolo. Vermelho-Escuro álico (LEa)

4.3.6.1. Teores de Nutrientes

As porcentagens de nitrogênio, potássio e magnésio; em ambos cortes, e de cálcio (no segundo corte) e enxofre (no primeiro corte) foram significativamente afetadas pela calagem (Tabelas 72 e 73). Porém os teores de fósforo (ambos cortes), cálcio (segundo corte) e enxofre (primeiro corte) năo variaram com as doses de calcário empregadas.

A porcentagem de nitrogênio na pärte aérea da galactia, no primeiro corte, mostrou redução no seu valor do nivel o para o nivel. 1 de calagem, entretanto esses valores no nivel 3 de calagem voltaram a aumentar. Tais valores es- 
tåo ácima de $1,89 \%$ de $\mathrm{N}$ obtido com essa forrageira cultivada em adubação completa por MIRANDA. (1979). Já no segundo corte, os teores de $\mathrm{N}$ foram linearmente incrementados com a calagem e, de um modo geral foram inferiores aos do primeiro corte, situando-se abaixo dos valores verificados por MIRANDA (1979).

A baixa nodulação pode explicar parcialmente os baixos teores de $\mathrm{N}$ obtidos com a galactia no segundo cor te. No primeiro corte, utilizando parte de suas necessidadés de $N$ do solo a galactia inåo teve restriçőes de crescimen to em termos de produçåo de matéria seca, entretanto, no segundo corte, diminuidas as reservas de $\mathrm{N}$ do solo e com a baixa nodulação (possivelmente inibida pelo $\mathrm{N}$ da matéria orgậnica, matéria orgânica $=3,0 \%$, ou ạinda ineficiência das estirpes ṇodulantes), houve-restriçőes na fixação biológica do "N com reduções no crescimento da galactia. Possivelmente, as quantidades de $\mathbf{N}$ orgânico mineralizadas foram insuficientes para suprir as necessidades da galactia, porém foram capazes de inibir o processo de fixaçăo biológica de $\mathrm{N}$. As porcentagens de cálcio (no primeiro ${ }^{2}$ corte) e magnésio (em ambos cortes) aumentaram significativamente com a elevaçåo nos niveis de calagem. Incrementos nos teores desses macronutrientes, com a aplicação de calcário, são des critos na literatura, para essa leguminosa forrageira (JONES \& FREITAS, 1970; FRANÇA et alii, 1973 e MONTEIRÓ, 1980). Para os teores de cálcio no primeiro corte, 0 desdobramento da interaçăo calagem $x$ molibdênio evidenciou que, no nível 2 de calagem, a aplicação de molibdênio resultou em teores mais elevados de cálcio. Enquanto que os niveis de calagem proporcionaram, apenas com a.utilizaçåo de molibdênio, incre 
mentos lineares e significativos sobre os teores de cálcio no primeiro corte (Tabelas 73 e 74 ).

Os conteúdos de potássio, de um modo geral foram diminuidos com a aplicação da calagem. No segundo corte, tais reduções podem ser atribuidas a efeitos de diluição em virtude do maior crescimento com a aplicaçåo da calagem e ou antagonismo cálcio com potássio (Tabela 73).

Os teores de enxofre na parte aérea da galaç tia no segundo corte mostraram redução quadrática com as doses de calcário (Tabela 73). Tais reduçőes podem ser atribuí das a efeitos de diluiçăo em virtude do maior crescimento da galactia com aplicação dos niveis de calcário. Considerando que aproximadamente $0,20 \%$ de $S$ na matéria seca (MALAVOLTA, 1989) seria uma concentração adequada para o crescimento da galactia, observa-se, pelos teores encoritrados no segundo corte, que provavelmente não houve restrições em termos de nutriçăo com enxofre.

Para os conteúdos dos micronutrientes, as análises de variância não demönstraram variações significativas da calagem, da aplicação de molibdênio, cobalto ou das interações sobre os teores de boro ou de ferro (Tabela 75). Os teores médios de ferro são considerados adequados para o crescimento da galactia. Já, os teores de boro situaram-se acima dos considerados adequados, entretanto aparentemente nåo foi observado sintomas de toxidez desse micronutriente ( Tabela 76).

As concentrações de cobre no primeiro corte, manganês e zinco, em ambos cortes, diminuíram significativa mente com os niveis de calagem (Tabela 76). Essas reduções obedeceram efeito quadrático para o manganês (primeiro corte) 
e zinco (segundo corte) e linear para o cobre (primeiro cor te) e manganês (segundo corte). As equações de regressăo representativas dessas reduçőes nos teores desses micronutrien tes com a calagem săo apresentados na Tabela 30. Reduções nos teores de zinco e manganês, com a aplicação de calcário, são descritas em galactia por MIRANDA (1979) e em outras leguminosas por WERNER \& MATTOS (1972).

Os teores de zinco acima de 20 ppm e de cobre entre 5 e 8 ppm obtidos para a galactia cultivada nesse so10, são considerados adequados para essa leguminosa.

Com relaçăo aoṣ teores de zinco na galactia no primeiro corte, verificou-se que a interação calagem $x$ co balto foi significativa. 0 desdobramento dessa interaçăo revelou que, na presença dos niveis 1 e 2 de calagem, o empre go do cobalto resultou em conteúdos mais elevados de zinco. Porém, na ausência de calagem, ọs teorẹs de zinco na galactia năo variaram com o uso do cobalto na adubação. Notou-se que, na ausência de cobalto, os teores de zinco diminuiram com a calagem, quadraticamente e em maior magnitude que na presença de cobalto, quando as reduçőes nos teores desse mi cronutriente foram lineares (Tabela 77). Na literatura consultada năo foi encontrado nentium relato para tal fato.

Pode-se admitir. que a calagem tenha diminuido mais a disponibilidade do $\mathrm{Zn}$ que a de Co o que permitiria maior competiçăo do último com o primeiro cujo teor, entăo, cairia.

Os teores de mánganês na parte aérea da galactia, em ausência de calagen em ambos cortes, estiveram acima de 570 ppm. Outros autores MIRANDA (1979) e MONTEIRO (1980) também obtiveram valores superiores a 570 ppm . de 
manganês na paitte aérea da gálactia cultivada sem a aplicação de calcário. Aparentemente, não foram evidenciados sintomas de toxidez de manganês na parte aérea dessa leguminosa. Porém, a galactia mostrou-se sensivel ao manganês, apre sentando menores produçð̋es de matéria seca, quantidades totais de nitrogênio e mais baixos peso seco'de nódulos no nível 0 de calagem. 0 excesso de manganês parece prejudicar mais à simbiose Rhizobium - leguminosa do que a produçåo de matéria seca. De fato a correlação simples entre os teores de manganês e o peso seco dos nódulos $(r=-0,92 * *)$ foi mais elevada que a do teor desse micronutriente com a produção de matéria seca da parte aérea da galactia ( $\left.r=-0,58^{* *}\right)$. Resultados semelhantes foram obtidos por FRANCo \& DÖBEREINER (197i) trabalhando com centrosema.

4:3.7. Galactia cultivada no solo Latossolo Vermelho Ama relo distrófico ( LVd)

4.3.7.1. Teores de Nutrientes

Na Tabela 78 são mostrados os resultados da análise de variância para os efeitos da calagem, molibdênio, cobalto e interaçðes sobre os conteúdos dos macronutrientes em galactia cultivada no solo. LVd. Verificou-se que a calagem influiu significativamente sobre os conteúdos de todos os macronutrientes, com exceção aos teores de fósforo no pri meiro corte. Foram, também, significativos os efeitos do molibdênio sobre os teores de nitrogênio e enxofre na matéria seca do segundo corte. Com relação aos conteúdos de macronutrientes observou-se que a interaçăo calagem $\times$ molibdênio para os teores de nitrogênio mostrou-se significativa. 
aplicaçåo de cobalto e as demais interaçðes nåo

mostraram efeitos significativos sobre os teores dos outros macronutrientes.

A porcentagem de nitrogênio no primeiro corte, da parte aérea da galactia do nivel 0 para o nivel 1 de calagem mostrou redução no seu valor; entretanto, tornou a aumentar, atingindo o máximo no nivel. 2 . de cal cário (proposto para elevaçåo do indice de saturaçåo em bases para 70\%).. Já, no segundo corte, o teòr de nitrogênio em qualquer nivel de calagem estava acima do valor $1,89 \%$ consi derada por MIRANDA (1979) como indicador de um estado nutricional adequado para gàlactia.

Para os conteúdos de nitrogênio no segundo corte a interação calagem $x$ molibdênio foi significativa. 0 desdobramento dessa interação mostrou que a aplicação de moIibdênio incrementou as concentraçōes de nitrogênio tanto na ausência como no nivel 1 de calạgem, porém nạo teve efeito significativo no nivel 2 de calagem. Possivelmente, o empre go do nivel 2 de calagem melhorou a disponibilidade do molib dênio do solo de modo que nessa condição nåo houve resposta a aplicação de molibdênio (Tabela 80 ).

Com a aplicação de niveis de calagem $(x)$ e sem a utilização de molibdênio,os teores de nitrogênio (y) incre mentaram linearmente de acordo com a seguinte equaçăo de regressão $\hat{y}=1,81+0,011 x$. Na presença de molibdênio, os aumentos nos conteúdos de $\mathrm{N}$ com a calagem obedeceram efeitos quadráticos, representados pela equaçåo $\hat{y}=2,30+0,027 x-$ $0,00033 x^{2}$

Os teores de fósforo na parte aérea da galactia, no primeiro corte (Tabela 79) praticamente nåo variaram 
com os niveis de calagem,permanecendo em torno de 0,20\%. Reduções lineares nessa variável foram constatadas no segundo corte. Os maiores teores de fósforo foram obtidós na ausência de calagem. Esse teor mais alto de fósforo coincide com o menor desenvolvimento da galactia, desse modo é possível a ocorrência de um efeito de diluiçåo do elemento no interior da planta com o maior crescimento. MIRANDA. (1979) e MONTEIRO (1980) também observaram teores de fósforo significativamente mais elevado em galactia, com a omissão da calagem mais cálcio num solo Podzólico Vermelho Amarelo.

Os teores de pọtássio na galactia, tanto no primeiro como no segundo cortes apresentaram um comportamento quadrático em funçăo dos niveís de calagem. No primeiro corte; as mais altas porcentagens desse. elemento estiveram nos niveis 0 e nivel 2 de calagem. Essa queda nos teores de potássio no nível intermediário de calạgem, também tem sido apontada: em outros trabalhos com leguminosas (JONES \& FREITAS, 1970; MONTEIRO, 1980). Já no segundo corte, houve reduções nos teores de potássio com a aplicaçăo dos niveis de ca lagem. Teores mais elevados de potássio foram encontrados no tratamento sem calagem. EPSTEIN (1975) relata que há um anta gonismo entre o cálcio e o mágnésio com o potássio que explicaria as diminuições do potássio com a calagem: . EVANS (1961) e DJKSHOORN et alii (1974) afirmaram que o potássio e magnésio competem pelos mesmos sitios de absorçăo. MIRANDA (1979) também observou em folhas de galactia uma correlaçåo negativa entre o teor de magnésio e de potássio. Confrontando os resultados obtidos com a literatura, observa-se concordância com os diversos autores. 
Com o emprego de niveis de calagem, os teores de cálcio e magnésio, tanto no primeiro como no segundo corte, aumentaram significativamente. Tal fato é esperado pois - calcário é fonte de cálcio e magnésio parà a... leguminosa. Esses acréscimos fọram lineares para os conteưdos de cálcio e quadráticos para os de magnésio, cujas equaçð̋es de régressåo såo mostradas na Tabela 34 .

A concentração de enxofre na parte aérea sofreu diminuiçăo com os niveis de calagem. Mesmo na ausência de calagem foram obtidos altos conteúdos de enxofre, proveniente da fonte de fósforo empregada o superfosfato simples ou do enxofre orgânico do solo. Por outro lado, a aplicação de molibdênio resultou em menores conteúdos de enxofre na parte aérea da galactia no segundo corte. Provavelmente deve ter ocorrido uma inibição competitiva entre o molibdato aplicado com o sulfato, reduzindo a absorçăo de enxofre. REISENAUER (1963) explica que há entre o enxofre e ơ molibdênio uma inibiçăo competitiva desses dois ânions de tamanhos semelhantes.

As Tabelas 81 e 82 mostram os resultados das análises de variância para os teores de micronutrientes na parte aérea da galactia. Verificou-se que a calagem afetou significativamente os conteúdos de manganês e zinco em ambos cortes, boro no primeiro corte e cobre no segundo corte. A aplicaçåo de Mo também alterou significativamente os conteúdos de Cu e Zn no segundo corte; enquanto que o uso do Co teve efeito significativo e positivo sobre os teores de $\mathrm{Cu}$ no primeiro corte. A interaçåo calagem $\times$ cobalto apresentou efeito significativo sobre os teores de $\mathrm{Zn}$ no primeiro corte, porém as demais interaçōes para os conteúdos dos outros micronutrientes nåo apresentaram efeitos significativos. 
Os teores de boro na matéria seca dessa legumi nosa, no primeiro corte, mostraram acréscimos com as doses de calcário aplicadas, resultando em efeito quadrático da ca lagem (Tabelas 34 e 82 ). Já, no segundo corte, o teor desse micronutriente não variou significativamente com a calagem. De um modo geral, os conteúdos de boro na parte aérea da galactia podem ser considerados altos, entretanto aparentemente não chegaram a causar toxidez às plantás.

No segundo corte; os teores de cobre diminuiram linearmente com a calagem. (Tabelas 34 e 82 ), em virtude da reduçåă na disponibilidade desse micronutriente. Os teores médios de cobre, na ausência de aplicaçăo de molibdênio ( 8 ppm de $\mathrm{Cu}$ ) foram mais elevados em comparação com a aplicação de molibdênio ( 4 ppm de Cu). MaCKAY et alii (1966) também encontrạram um antagonismo entre o cobre e o molibdênio, semelhante ao observado no presente trabalho.

A aplicaçåo dos niveis de calagem, em 8 ambois cortes, corresponderam a decréscịmos nos teores de manganês e zinco. Reduçőes desses teores em galactia com a calagem foram relatadas por MIRANDA (1979) e MONTEIRO (1980). A aplica ção do calcário provavelmente reduziu a disponibilidade desses dois micronutrientes (Tabelas 34 e 82 ).

Com a omissăo da calagem, o teor de manganês atingiu no primeiro corte valores de 611 ppm. MIRANDA (1979) cultivando a galactia em ausência de calagem e de cálcio, ob teve entre 600 e 700 ppm de Mn na matéria seca da parte aérea. Embora, aparentemente nåo tenha sido evidenciado sintomas visuais de toxidez de manganês na ausência da calagem, houve limitaçőes no crescimentto e na nodulação da galactia. 
A interação calagem $x$ cobalto teve efeito significativo sobre os teores de zinco no primeiro corte na matéria seca da parte aérea da galactia . O desdobramento dessa interação revelou que, na.ausência da calagem, a aplicação de cobalto diminuiu os conteúdos de zinco (Tabela 83). A dis ponibilidade tanto do cobalto como do zinco é mais elevada em $\mathrm{pH}$ mais ácido. Os resultádos obtidos no presente trabalhọ evidenciam, na ausência de aplicação de calcário, uma provável inibiçăo competitiva entre esses dois micronutrientes. Com a aplicação de calcário, o uso do cobalto não afetou sig nificativamente os teores de zinco na parte aérea da galactia. A utilizaçåo de niveis de calagem $(x)$ reduziu linearmente os teores de zinco $(y)$, obedecendo as seguintes equaçőes de regressåo: a) sem uso de cobalto $\hat{y}=53,5 \cdots-0,49 x$. $\left(\dot{r}^{2}=-0,99\right)$ e b) com o uso de cobalto $\hat{y}=47,5-0,37 x\left(r^{2}=\right.$ $-0,99)$.

4.4. Nitrogênio Total Acumiulado

4.4.1. Em Soja perene

A análise de variância (Tabela 84) para as quantidades totais de nitrogênio evidenciou efeitos significativos ( $P \leqslant 0,01)$ para calagem e para a calagem $x$ molibdênio $(P \leqslant 0,05)$.

As quantidades totais de nitrogênio acumuladas na parte aérea da soja perene cultivada nos solos LVd e LEa em função dos niveis de calagem săo apresentados nas Tabelas 85 e 86 . No geral, as quantidades de $N$ total acumuladas na parte aérea da soja perene aumentaram com a calagem. 
No solo LVd fol verificado, no primeiro corte, um efeito de diluiçăo nos teores de $\mathrm{N}$ em virtude do maior crescimento, sendo nesse corte a elevação das quantidades de nitrogênio decorrèntes da maior produção de matéria seca com a aplicação de calagem. Já, no segundo corte, os aumentos quadráticos nas quantidades totais de niitrogênio são decorrentes dos efeitos da calagem incrementando as produçơes de matéria seca (Tabela 19) e os teores de nitrogênio (Tabela 58) da soja perene.

No solo LEa observou-se efeito significativo da interaçåo calagem $x$ molibdênio no primeiro corte e da cálagem em ambọs cortes. 0 desdọbramento dessa interação revelou que a calagem, tanto em presença como auséncia de molibdênio incrementou significativa e linearmente as quantida des de nịtrogênio acumulados na parte aérea da soja perene (Tabela 84).

Por outro lado, a aplicação de Mo, na ausência de calagem nåo proporcionou incrementos significativos sobre as quantidades totais de $\mathbf{N}$ acumuladas. Com o emprego da cala gem nos niveis 1 e 2, o uso de Mo mostrou efeito expressivo aumentando as quantidades totais de $\mathrm{N}$ da soja perene (prime ro corte) cultivada no solo LEa (Tabela 86). A falta de resposta a esse micronutriente nạ ausência de calagem permite supor que, nas condições ácidas ( $\mathrm{pH}$ final 4,1) o molibdênio teria sido adsorvido às partículas do solo (KAMPRATH, 1972), tais como óxidos de ferro e aluminio, conforme descrito por REISENAUER et alii (1962). TRUO NG et alii (1972). propס̃em que a disponibilidade relativamente alta de manganês no so10, pode influenciar a nåo resposta ao molibdênio. Este fato pode ter ocorrido, conforme descrito nos iteris 2.2.1. 
A aplicaçåo de níveis crescentes de calcário proporcionaram incrementos na produçåo de matéria seca, que parecem estar associados à maior fixaçåo de $N$, conforme indicado pelos teores de $\mathrm{N}$ na parte aérea (Tabẹla 53). Respostas à calagem, devido ao estimulo na fixaçåo de $\mathrm{N}$ também foobservadas por FRANÇA et alii (1973b) e por MUNNS ${ }^{2}$ et alii (1977).

A calagem produzindo alterações quimicas no so 1o, como por exemplo elevaçåo do $\mathrm{pH}$, maiores disponibilidades de nutrientes ( $P, \mathrm{Ca}, \mathrm{Mg} \mathrm{e}^{\mathrm{Mo}}$ ) teria beneficiado a fixaçăo de $\mathrm{N}_{2}$, aumentando a concentração de $\mathrm{N}$ e a produção de ma téria seca na parte aérea. $\mathrm{O} \mathrm{pH}$ do solo aumentou no final do experimento de 4,4 para 5,3 no nivel $\mathrm{C}_{1}$ para o $\mathrm{C}_{2}$ Essa diferença no $\mathrm{pH}$ poderia ter contribuido para incrementar a fixaçรo de $\mathrm{N}_{2}$ no tratamento $\mathrm{C}_{2}$ - ANDREW \& JOHNSON (1976), estudando o efeito do $\mathrm{pH}$ sobre a composiçăo química de um grupo de leguminosas tropicais e temperadas; verificaram que .. em plantas noduladas o aumento do pH elevou a concentraçåo de $\mathrm{N}$ na maioria das espécies. Essa elevação na concentração de $\mathrm{N}$ resultou em aumentos no crescimento relativo da soja perene (ANDREW, 1976).

O suprimento de cálcio (calagem ou Ca do super fosfato simples) elevou seus teores de 0;90 para $2,80 \mathrm{~m}$ eq/ 100ml TFSA, porém, mesmo na ausência de calcário, os conteú dos de cálcio na matéria seca da soja perene situaram-se em torno de 1,40\%, que possivelmente nåo se mostraram limitantes para a produçåo e fixaçåo de nitrogênio da soja perene.

Nas Tabelas 17 e 21 săo apresentadas as equações de regressão para as quantidades totais de nitrogênio na parte aérea da soja perene èm função dos niveis de calcário. 


\subsubsection{Em centrosema}

Os resultados da análise de variância (Tabela 87) mostraram efeitos significativos da calagem, em ambos cortes e nos dois solos, e da aplicação de molibdênio no solo LEa (ambos cortes) e no solo LVd (no segundo corte) e da interação molibdênio x cobalto (solo LEa, no segundo corte) sobre as quantidades totais de nitrogênio acumuladas na parte aérea da centrosema.

As quantidades totais de nitrogênio acumuladas na parte aérea da centrosema são apresentados na Tabela 88. Observou-se com a aplicaçåo dos niveis créscentes de calcário uma maior acumulação de nitrogênio na parte aérea da cen trosemá.

Para a centrosema cultivada no solo LÉa, as ele vações nas quantidadẹs de nitrogênio acumuladas, no primeiro corte, foram decorrentes dos incrementos nos teores de nitrogênio. Já, no segundo corte, tanţo as elevações nos teores de nitrogênio (Tabela 62) como os aumentos de produção de matéria seca (Tabela 22) proporcionaram acumulações crescentes de $N$ com os niveis de calagem.

As equações de rẹgressão para as variaçōes nas quantidades totais de nitrogênio em funçåo da aplicaçåo. de calcário são apresentadas na Tabela 24 . Elevações no nitrogênio total da centrosema em função da calagem, também foram relatadas por ANOREW \& NORRIS (1961) e WERNER \& MATTOS (1972). Conforme pode ser verificado pelas quantidades totais de nitrogênio na ausência de calagem (Tabela 88), algum fator rela cionado com a acidez do solo, tal como excesso de manganês (Tabela 64), deve ter prejudicado a eficiência dos nódulos em fixar o $\mathrm{N}_{2}$ atmosférico. 
A utilização dó molibdênio resultou em efeitos positivos, elevando as quantidades totais de nitrogênio acumu ladas na parte aérea da centrosema cultivada no solo LEa em ambos cortes. É sabido que o molibdênio é essencial para fixa çăo simbiótica de $\mathrm{N}_{2}$, sendo maiores quantidades necessárias para esse processo que para o metabolismo geral das plantas (ANDERSON, 1956a). Esses resultados positivos, com a aplicaçăo de molibdênio demonstram a importância de sua utilizaçăo para a centrosema cultivada nesse solo.

A interação molịbdênio x cobalto, para as quan tidades totais de nitrogênio acumuladas na parte aérea da cen trosema no segundo corte, mostrou-se significativa. 0 desdobramento dessa interação revelou que a aplicação conjunta de cobalto e molibdênio resultou em maiores acumulações de $\mathbf{N}$ do qué a aplicação de cada um desses micronutrientes isoladamen te (Tabela 89). Tal fato vem corroborar com os trabalhos realizados por AHMED \& EVANS (1960) e KLIEWER \& EVANS (1863) que demonstraram que a ausência de cobalto prejudicou o acúmulo de $\mathbf{N}$ em plantas dependentes da fixação biológica do nitrogênio. Esse fato evidencia que esses dois micronutrientes foram limitantes para a acumulaçåo de $\mathrm{N}$ em centrosema cultivada no solo LEa.

No solo LVd, conförme já relatado a calagem incrementou os teores de nitrogênio em ambos cortes (Tabela 67) e as produções de matéria seca (Tabela 26) da centrosema no segundo corte, resultando consequentemente em elevaçóes sobre as quantidades totais de $\mathrm{N}$ acumuladas. Esses resulicados concordam com os obtidos por DöBEREINER \& ARONOVICH (1966), JONES et alii (1970) e MONTEIRO (1980). As mais baixas quantidades totais de nitrogênio em centrosema foram obtidas na au sência de calagem. 
A calagem proporcionou no solo LVd, condiçōes

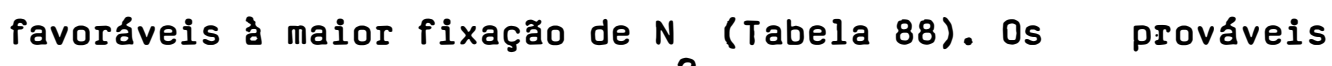
efeitos benéficos do emprego do. calcário foram a elevação do $\mathrm{pH}$ de 3,9 para 5,3 , reduçåo do $\mathrm{H}+\mathrm{Al}^{+++}$de 3,4 para 2,0 e. $\mathrm{mg} / 100 \mathrm{ml}$ de TFSA, maior suprimento de $\mathrm{Ca}^{++}$de 0,9 para 2,1 e.mg/:00 ml de TFSA e diminuição do manganês tóxico (Tabela 71). Originalmente o solo LVd continha $2,7 \%$ de matéria orgâni ca, após o cultivo da centrosema os conteúdos de matéria orgâ nica, em todos os niveis de calagem, baixaram igualmente pära 1,9\%. Os baixos conteúdos de $\mathbf{N}$ na parte aérea da centrosema, no primeiro corte, ou as menores quantidades totais de nitrogênio parecem indicar que o sistema de fixação de $\mathrm{N}_{2}$ não estava funcionando plenamente no primeiro corte. Possivelmente, o N proveniente de matéria orgânica mineralizada prejudicou inicialmente a fixação biológica. Já, no segundó corte, após a exaustão do nitrogênio mineral, a fixação : biológica passou a operar com maior potencialidade.

A aplicação de molịbdênio também elevou signifí cativamente as quantidades totais de nitrogênio na parte aérea do segundo corte da centrosema cultivada no solo LVd. Resultados semelhantes foram obtidos por DE POLLI;: et alii (1976), FANCELLI et. alii (1981) e MONTEIRO et alii (1983c) cultivando centrosema em diversos solos. A omissão de molibdê nio resultou em diminuições ná eficiência de fixação biológica dos $\mathrm{N}_{2}$ conforme mostraram as menores porcentagens de nitró gênio (Tabela 68).

$\mathrm{Na}$ Tabela 27 pode-se observar as equações de re gressão para o nịtrogênio toțal, em função dos niveis de cala ge, em centrosema cultivada no solo LVd. 
4.4.3. Em Galact1a

Nas Tabelas $9 \dot{0}$ e 91 constam os. resultados das análises de variância e os dados obtidos para as quantidades tótais de nitrọgênio acumuladas na parte aérea de galactia cultivada nos solos LEa e LVd em função dos niveis de calagem.

Constatou-se que a aplicação de calcário' resultou em incrementos significativos sobre o nitrogênio total na galactia nos dois solos e em ambos cortes. Elevações nessa variável com a calagem, cultivando essa leguminosa, também foram obtidas por CARVALHO et alii (1988) trabalhando num solo Latossolo Vermelho Amärelo Álico de Minas Gerais.

Conforme pöde ser observado na T̈abela 910 emprego da calagem elevou com efeito quadrático as quantidades totais de $\mathrm{N}$ no solo LV.d em ambos cortes, e, no solo LEa no primeiro corte, porém teve efeitos lineares no solo LEa no se gundo corte. As equações de regressão representativas dessas variações são apresentadas nas Tabelas 30 e 34 .

Observa-se que, com a calagem, as quantidades totais de $\mathrm{N}$ acumuladas no solo. LVd no segundo corte foram su periores às encontradas nos níveis equivalentes de calcário no primeiro corte. Essas maiores acumulações de $\mathrm{N}$ são decọrrentes de maiores produções de matéria seca da parte aérea e teores de $\mathrm{N}$ mais elevados nos niveis 1 e 2 de calagem no segundo corte.

Para a galactia cultivada no solo LEa, ressalta ram-se reduções nas acumuläçס̃es de $N$ no segundo corte em relação ao primeiro corte. Tais diminuições podem ser atribuidas a baixa infectividade e reduzida eficiência de fixação 
biológica de $\mathrm{N}_{2}$ pelos estirpes nodulantes, que refletiram em baixa nodulaçåo, baixos teores de $\mathbf{N}$ na parte aérea e reduçơes no crescimento. Conforme já discutido no item 2.6.1. os altos conteúdos de matéria orgânica do solo, com reserva potencial de $N$, sustentaram o crescimento inicial, prejudicando a nodulação, sendo porém insuficientes para sustentar o crescimento da rebrota.

O emprego do molibdênio resultou em incrementos significativos nas quantidades totais de $N^{\cdot}$ acumulado na parte aérea da galactia no ségundo corte no solo LVde, no primeiro corte no solo LEa. Por razões já expostas no item 1.4.2., o molibdênio como constituinte da nitrogenase, enzima responsável pela fixação biológica do $\mathrm{N}_{2}$, incrementou a eficiência da fixação biológica do $\mathrm{N}_{2}$, elevando a nodulaçăo, os teores de $N$, a produção de matéria seca da galactia e portanto as quantidades totais de $\mathrm{N}$ acumuladas.

\subsection{Molibdênio nas Leguminosas}

Na Tabela 92 são mostrados os resultados da aná lise de variância para os coriteúdos de molibdênio na parte aérea das leguminosas soja perene, centrosema e galactia cultivadas nos solos Latossolo. Vermelho Amarelo distrófico (LVd) e no solo Latossolo Vermelho Escuro Álico (LEa).

\subsubsection{Molibdênio na Parte Aérea Soja Perene}

Para a soja perene cultivada no solo LVd (em ambos cortes) e no solo LEa (segundo corte) foram significati vos $(P \leqslant 0,01)$ os efeitos da calagem, da aplicação de molibdẹ 
nio, de cobalto e, das interaçôes calagem $x$ molibdênio, calagem $x$ cobalto e molibdênio $x$ cobalto sobre os conteúdos de molibdênio. Enquanto que para os dados do primeiro corte da soja perene cultivada no solo Latossolo Vermelho Escuro álico somente a aplicação de molibdênio mostrou efeito significativo $(P \leqslant 0,05)$ incrementando os teores de molibdênio.

Para a soja perene cultivada no solo LVd, o desdobramento da interação calagem $x$ molibdênio revelou, em ambos cortes, efeito significativo e positivo da calagem, somente na presença de molibdênio. Por outro lado, em todos os niveis de calagem, o emprego de Mo como fertilizante resultiou em significativos acréscimos nos conteúdos desse micronutrien te (Tabela 93). Esses acréscimos obedeceram efeitos quadráticoṣ (Tabela 94), cujas equaçờes de regressão mostrando tais efeitos são apresentadas na Tabela 95. A ṇão aplicaçăo de Mo corresponderam teores de Mo significativamente menores, mesmo com o emprego do nivel mais elevado de calagem (Tabela 42). Os conteúdos de molibdênio na parte aérea da soja perene cultivada no solo LVd oscilaram de 0,02 ppm na ausência de aplicação de Mo até $2,48 \mathrm{ppm}$ com aplicação de Mo no nivel mais elevado de calagem (Tabela 93). Na ausência de calagem., as concentrações de molibdênio situaram-se abaixo de 0,1 ppm, concentração descrita para plantas deficientes (KABATA- PENDIAS \& PENDIAS, 1984). A aplicação de calcário, em ambos solos, mostrou-se eficaz para aumentar a disponibilidade do molibdênio, elevando sua concentração na parte aérea da soja pe rene.

Para o solo LEa, o desdobramento da interação calagem $x$ molibdênio evidenciou efeito positivo e significativo da calagem tanto na ausência como na presença de aplica 
ção de molibdênio. Examinando-se os conteúdos' de molibdênio obtidos na parte aérea da soja perene, no segundo corte, sem a aplicação de molibdênio, verificou-se que o emprego da calagem proporcionou significativos incrementos que obedeceram a um efeito quadrático, por outro lado, na presença de molibdênio a calagem aumentou linearmente os conteúdos de Mo (Tabe la 94 ).

A aplicação de molibdênio como era esperado, re sultou em expressivos incrementos nos conteúdos de Mo na maté ria seca da parte aérea da soja perene no segundo corte em todos os niveis de calagem, conforme mostram os dados apresentados nas Tabelas 92,93 e 94 .

Para a soja perene cultivada no solo LEa os con teúdos de Mo variaram entre o minimo de 0,03 ppm obtidos na ausência da calagem sem uso de Mo, até o máximo. de 4,68 ppm com a aplicação de Mo e no nível mais elevado de calagem (Ta bela 93).

\&

0 desdobramento da interação calagem $x$ cobalto mostrou efeito significativo e positivo da calagem tanto na ausência como na preșença de aplicação de cobalto sobre . os teores de molibdênio na parte aérea da soja perene cultivada no solo LVd em ambos cortes e no solo LEa lı no segundo corte (Tabelas 94 e 97). Na Tabela 98 såo apresentadas as equações de regressão que representam essas variações em função dos ní veis de calagem e do emprego de cobalto.

Outro fato que chama a atenção é que a soja perene cultivada no solo LEa (dados do segundo corte) apresentou conteúdos de Mo superiores aos obtidos quando essa legumi nosa foi cultivada no solo LVd. Além de que a simples prática da calagem no solo LEa foi suficiente para proporcionar ex pressivos aumentos nos conteúdos de Mo da soja perene o que não foi observado no solo LVd. 
Para a soja perene também foi significativa a interação molibdênio x cobalto cujo desdobramento revelou que a utilização de molibdênio contribuiu para elevar significati vamente $(P \leqslant 0,01)$ os conteúdos de Mo na parte aérea da soja perene cultivada no solo LVd (em ambos cortes) e no solo LEa (no segundo corte) mediante o emprego ou não do cobalto. A adição conjunta do $\mathrm{Co}$ + Mo contribuiu para incrementar efetivamente os conteúdos de molibdênio na soja perene (Tabela 96) porém o emprego de cobalto sem molibdênio não alterou... significativamente os conteúdos de Mo.

4.5.2. Molibdênio na Seménte de Soja periene

Analisando-se o conteúdos de molibdênio nas sementes do soja perene empregadas no presente estudo, obtevese uma concentração média de $2,1 \mathrm{ppm}$. Conforme demonstrou MEAGHER et alii (1952) a. deficiência de Mo nem sempre \& poderiam ser demonstrada em plantas oriundas de sementes produzidas comercialmente que contintiam de 0,5 a 5 ppm de Mo. A ausência de resposta a aplicação de molibdênio na soja perene em termos de produção de matéria seca, quantidades totais de nitrogênio, nodulaçăo, teores de macronutrientes e de micronu trientes (com exceção ao cobalto e ao molibdênio) concordam com a observação de MEAGHER et alii (1952), GURLEY \& GIDDENS (1969). Do presente experimento pode-se inferir que pelo menos parcialmente o molibdênio contido na semente de soja perene supriu as necessidades de Mo durante os dois cortes executados tanto no solo LVd como no solo LEa, a outra parte seria o Mo do solo ou como impureza dos fertilizantes utilizados. 
4.5.3. Molibdênio na Parte Áerea da Centrosema

Com relação aos conteúdos de molibdênio em centrosema foram observados éfeitos significativos da calagem e da aplicação de molibdênio nos dois cortes para o solo LEa, no segundo corte no solo LVợ e da interação calagem $x$ molibdê nio nos dois solos em ambos os cortes (Tabela 92), enquanto que a aplicação de cobalto e as demais interações não foram significativas.

O desdobramento da interação calagem $x$ molibdênio evidenciou que, na ausência de aplicação de Mo, a calagem nåo teve efeito significativo sobre os conteúdos de Mo na matéria seca da parte aérea da centrosema cultivada em ambos os solos nos dois cortes. Porém, na presença de fertilização com Mo, a calagem teve efeito significativo linear e positivo no solo LVd e quadrático no solo LEa para os conteúdos de Mo (Ta bela 92 e 94). A utilização de molibdênio incrementou, is os conteúdos desse micronutriente na parte aérea da centrosema, em ambos solos e nos dois cortes, no nivel mais elevado de ca lagem estudado. Enquanto que no nivel intermediário de calagem estudado, a aplicação de Mo resultou em acréscimos significativos nos conteúdos de Mo apenas no segundo corte da parte aérea da centrosema cultivada no solo LVd. Na Tabela 95 estão as equações de regressão que estimam as variações nos conteúdos de Mo em centrosema em função da calagem e da aplicação ou não de Mo.

Para a centrosema cultivada no solo LVd os conteúdos de Mo oscịlaram entre 0,01 e 8,41 ppm, enquanto no so lo LEa esses valores estiveram entre 0,07 ppm e 1,89 ppm (Tabela 93). Os conteúdos de Mo, mediante a aplicação de molibdẹ 
nio, estiveram acima de 0,1 ppm considerado critico para as plantas, porém na ausência de utilização de Mo e de calagem, os conteúdos desse micronutriente estiveram abaixo de 0,1 ppm de Mo.

Outro fato interessante foram os..acréscimos sig nificativos nos conteúdos de Mo, observados em consequência da aplicação de molibdênio (Tabela 93), sobre a matéria seca da rebrota nos dois solos.

Para o solo LVd, a correlação simples entre os conteúdos de molibdênio e as produções de matéria seca da par te aérea -da centrosema foram significativas e positivas $(P \leqslant$ $0,05)$.

4.5.4. Molibdênio na Semente de Centrosema

As sementes de centrosema utilizadas no presente trabalho apresentaram concentrações médias de 1,3 $\mathrm{ppm}$ de Mo. Para essa leguminosa tal quantidade de Mo armazenada na semente, aparentemente, foi insuficiente para dar atendimento às necessidades da planta. Tendo em vista as respostas positivas da aplicação de Mo sobre as quantidades totais de nitrogênio na parte aérea da centrosema no segundo corte para o solo LVd e em ambos cortes para o solo LEa.

4.5.5. Molibdênio na Parte Aérea da Galactia

Os resultados da análise de variância mostrados na Tabela 92, evịdenciaram efeitos significativos $(P \leqslant 0,01)$ da calagem sobre os conteúdos de Mo na matéria seca da parte aérea da galactia cultivada no solo LEa (ambos cortes) e no 
solo LVd ( 2 o corte). Foram, também, significativos ( $P \leqslant 0,01)$ os efeitos da aplicação de Mo e a interaçăo calagem x molibdẹ nio para a galactia cultivada no solo LVd (segundo corte) e no solo LEa (primeiro corte).

0 desdobramento da interação calagem $x$ molibdê nio para a galactia cultivada no solo LVd (2o corte) e no solo LEa ( 19 corte) evidenciou que somente na presença de Mo, a calagem teve efeito significativo sobre os conteúdos de Mo. Entretanto, a aplicaçăo de Mo, em todos os niveis de calagem, resultou em incrementos significativos e positivos no solo LVd (Tabela 92 e 93) enquanto que no solo LEa (10 corte) somente na ausência ou no nivel mais elevado de calagem a aplicação de Mo elevou significativamente os conteúdos de Mo. A calagem juntamente com molibdênio resuḷtou em efeitos quadráticos sobre os conteúdos de Mo na galactia conforme mostram os dados apresentados nas Tabelas 94 e 95.

Para essa leguminosa os conteúdos de molíibdênio oscilaram entre 0,01 e 3;65 ppm quando cultivada no soló LVd e de 0,05 a 1,40 ppm ao ser cultivada no solo LEa (Tabela 93). A correlação simples entre as produções de matéria seca, número e peso seco de nódulos com os conteúdos de molibdênio para a galactia cultivada no solo LEa não foram significati-

$\frown$ vas. Por outro lado, quando essa leguminosa foi cultivada no - solo LVd, a correlação simples entre os conteúdos de Mo e as produções de matéria seca, e de $N$ total dados do segundo corte, bem como os conteúdos de Mo e. o peso seco dos nódulos mostraram-se significativas $(P \leqslant 0,05)$ e positivas.

Ressalta-se, portanto, para a galactia cultiva da no solo LVd, a importância da aplicação do molibdênio, correlasionado-se positivamente com os incrementos na nodulação. 
Tal fato concorda com os conceitos de ANDREW (1962) sobre o importante papel do molibdênio no processo de fixação simbiótica do $\mathrm{N}$ atmosférico, sendo as quantidades requeridas para isto bem superiores aqquelás exigidas para o próprio crescimen to das leguminosas.

\subsubsection{Molibdênio na Semente da Galactia}

As sementes de galactia empregadas no presente experimento continham em média 1,9 ppm de molibdênio. Possivelmente, parte desse Mo contido na semente foi aproveitado para atendimento dos requerimentos em Mo pela galactia. Entre tanto, nåo deve ter sido suficiente para atender as necessidades totais em Mo, pois a aplicação de Mo incrementou a produção de matéria seca da galactia (1o corte) no solo LEa e no solo LVd (20 corte).

\subsection{Cobalto nas Leguminosas.}

$\mathrm{Na}$ Tabela 99 são mostrados os resultados da aná lise de variância para os conteúdos de cobalto na parte aérea das leguminosas soja perene, centrosema e galactia cultivadas nos solos Latossolo Vermelho Amarelo distrófico.(LVd) e no so lo Latossolo Vermelho Escuro álico (LEa).

4.6.1. Cobalto na Parte Aérea da Soja perene

Para a soja perene mostraram-se significativos os efeitos da calagem nos dois solos e em ambos cortes, enquanto que a aplicaçăo de cobalto e a interação calagem $x$ co 
balto foram significativas no solo LEa (ambos cortes) e no so lo LVd (no segundo corte) sobre os conteúdos de cobalto.

Os conteúdos médios de cobalto na parte aérea da soja perene de uma maneira geral, estiveram acima de 0,07 ppm considerado como limite minimo de deficiência de cobalto na matéria seca das forrageiras por JARDIM et alii (1966).

0 desdobramento da interação calagem $x$ cobalto para a soja perene cultivada no solo LVd (segundo corte) revelou que, com a omissão da calagem, a aplicaçăo de cobalto incrementou significativamente os teores de cobalto na matéria seca. Com a aplicaçåo da calagem os teores de cobalto foram similares tanto em presença como ausência de cobalto (Tabelas 99 e 101). Por outro lado, os teores de cobalto na par te aérea da soja perene, na ausência de cobalto, incrementaram com a aplicação dos niveis de calagem, tais elevações obe deceram a efeitos quadráticos conforme equação de regressão apresentada na Tabela 102. Porém. na presença de cobalto não foram significativos os efeitos dos niveis de calagem.

Para o solo LEa; o deșdobramento da interação calagem $x$ cobalto revelou que a adiçåo de cobalto tanto na ausência da calagem como no rivel 1 de calagem resultou em aumentos significativos nos teores de cobalto na parte aérea da soja-perene. Entretanto no nivel. 2 de calagem os teores de cobalto foram semelhantes mediante o emprego ou não desse micronutriente (Tabela 100). Observa-se que os aumentos mais expressivos nos teores desse micronutriente foram obtidos em ausência da calagem. Esse fato é esperado pois a ḍisponibilidade do cobalto é maior em condições de acidez. Nesse solo a calagem, elevando o pH, resultou em reduções lineares nos teo res de cobalto tanto em presença como na ausência da aplica- 
ção de cobalto. Efeitos similares da calagem foram observados POI MITCHELL (1962).

No nivel 2 de calagem, e sem adição de cobalto no solo LEa, os conteúdos de cobalto baixaram a niveis inferlores a 0,0? ppm de Co considerado limiar para deficiência desse micronutriente.

Outro fato interessante observado para essa espécie forrageira, foi que, no geral os conteúdos de cobalto na matéria da parte aérea da soja perene cultivada no solo LEa foram ligeiramente inferiores aos encontrados. no solo LVd. Tais variações podem ser atribuidas, provavelmente, as diferentes concentrações originais de cobalto, entre esses dois solos, e aos conteúdos mais elevados de matéria orgânica no solo LEa (3,0\% de matéria orgânica) em relação ao solo LVd ( $1,8 \%$ de matéria orgânica).. segundo TISDALE \& · NELSON .(1975) e BLOOMFIÉLD (1981) aumentos no conteúdo de matéria orgânica dos solos são, geralmente, acompanhados por ç్రీeduções na disponibilidade do cobalto. .

\subsubsection{Cobalto na Parte Aérea da Centrosema}

Para os téres de cobalto na parte aérea da cen trosema verificaram-se efeitos significativos da calagem nos solos LVd e LEa (segundo corte), do cobalto nos dois solos e em ambos cortes e para interação calagem $x$ cobalto no segundo corte no solo LVd.

Desdobrando-se a interação calagem $x$ cobalto observou-se, no solo LVd (segundo corte) que, quando a calagem foi omitida, conteúdos mais elevados de cobalto foram encontrados mediante a adiçåo desse micronutriente. Empregando 
-se os níveís de calcário $1 \dot{e} 2$, os teores de cobalto na paI te aérea da centrosema foram similiares tanto na presença como na ausência de aplicação de cobalto. Na ausência de cobalto, a utilização de níveis de calcário não afetou significativamente os conteúdos de cobalto na parte aérea da centrosema (Tabela 101). Entretanto, com a adiçăo de cobalto, os níveis de calagem reduziram linearmente os conteúdos desse micronutriente na parte aérea da centrosema, cuja equação de regressåo é apresentada na Tabela 102. A calagem elevando o pH diminuiu a disponibilidade do cobalto.

Os conteúdos médios de cobalto na parte aérea da centrosema situaram-se acima de 0,07 ppm, considerado como critico, sendo também superiores aos 0,11 ppm encontrados por GALLO et alii (1974).

No solo LEa a prática da calagem também, diminui os conteúdos de cobalto na parte aérea da matéria seca da centrösema no segundọ corte.

A adição de cobalto na forma de $\mathrm{CoCl}$ resultou em acréscimos nos conteúdos de cobalto a niveis 2 superiores ao considerado critico, sem contudo afetar a nodulação, os teores de nitrogênio e nem o crescimento da centrosema. Como as quantidades de cọbalto requeridas pelas plantas é muito pequena, é possivel que esse micronutriente tenha sido adicio nado como impureza do șuperfosfato simples usado como fonte de fósforo. Segundo SENESI \& POLEMIO (1981), estudando o conteúdo de micronutrientes inorgânicos, obtiveram em média 16 ppm de cobalto no superfosfato simples. 


\subsubsection{Cobalto na Parte Aérea da Galactia}

Com relação aos conteúdos de cobalto em galactia, constatou-se efeito significativo da calagem, da aplicação de cobalto e da interação calagem x cobalto nos dois solos e nos dois cortes, conforme mostram os resultados da análise de variância apresentados na Tabela 99.

o desdobramento da interaçåo calagem $\dot{x}$ cobalto revelou que, na auséncia da calagem, o emprego de cobalto resultou em conteúdos mais elevados dessemicronutriente na parte aérea da galactia cultivada nos dois solos tanto no primei ro como no segundo cortes. No nivel 1 de calagem, a utilização de cobalto, no segundo corte correspondeu a teores mais elevados de cobalto para essa leguminoṣa cultivada em ambos solos. Já, nọ nível 2 de calàgẹ a aplicação ou não de cobalto nåo alterou significativamente os teores desse micronutriente (Tabela 100).

3

Nas condições de acidez originais dos ' solos LVd e LEa a maior disponibilidade do cobalto empregado resultou em acumulações mais elevadas desse micronutriente. A medi da que os valores de $\mathrm{pH}$-foram incrementados pela calagem houve reduções na disponibilidade do cobalto de modo que no nivel mais alto de calagem não houve resposta a adição de cobal to.

A prática da calagem sem adição de cobalto redu ziu linearmente os conteúdos de cobalto, porém em presença de cobalto essas reduçôes foram ora lineares ora quadrática, con forme pode ser observado pelas equações de regressão apresentadas na Tabela 102. 
A galactia cultivada nas condiçסes do presente experimento apresentou concentraçסes de cobalto superiores a $0,20 \mathrm{ppm}$ consideradas não limịtantes ao desenvolvimento des sa forrageira. 
5. CONCLUSÕES

Os resultados obtidos permitiram estabelecer as seguintes conclusð̃es:

1. O emprego da calagem elevou o pH, Breduziu $\mathrm{H}^{+}+\mathrm{Al}^{3+}$, incrementou os teores de cálcio e de magnésio tro cáveis, e a porcentagem de saturação em bases do solo, tanto no solo LVd cultivado com capim colonião como nos solos LVd e LEa cultivados com as leguminosas;

2. A adubação fosfatada, proporcionou expressivos aumentos nas produçðes de matéria seca, quantidades totais de nitrogênio e teores de fósforo no capim colonião no solo estudado;

3. A. utilização da calagem aumentou a eficiência do fósforo aplicado;

4. A aplicação conjunta da calagem è da adubação fosfatada corresponderam valores mais elevados de produção de matéria seca e quantidades totais de nitrogênio acumu ladas na parte aérea do capim colonião; 
5. A năo aplicaçăo de micronutrientes limitou o crescimento, em termos de produção de matéria seca, do capim coloniåo somente após o terceiro corte;

6. A aplicação de micronutrientes (incluindo o molibdênio e o cobalto) incrementou os conteúdos de molibdênio e de cobalto no capim-colonia acima dọs niveis considera: dos criticos;

7. A calagem, elevando o pH, melhorou à disponibilidade do molibdênio aplicado, resultando em maiores acumulaçб̋es de Mo na parte aérea do coloniåo;

8. A partir do segundo corte, a calagem reduziu os conteúdos de cobalto na matéria seca da parte aérea do capim-colonião. Em virtude da diminuição na disponibilidade desse micronutriente com a elevaçăo dọ pH;

9. Os teores de macro e micronutrientes na parte aérea do capim-coloniăo variaram significativamente com a calagem, com a adubaçåo fosfatada e com a aplicaçåo de micronụtrientes;

10. Para a soja perene, cultivada no solo LEa, a produçåo de matéria seca na parte aérea, nas raizes e na planta inteira, nitrogênio total e a nodulaçåo (número e peso seco de nódulos) aumentaram significativa $e^{*}$ : linearmente em funçåo da calagem. Para essas variáveis, os valores máximos seriam alcançados com niveis de calagem superiores ao nivel máximo empregado para essa leguminosa nesse solo;

11. A produção de matéria seca da parte aérea (segundo corte), das raízes, da planta inteira, nitrogênio to tal e nodulação da soja perene cultivada no solo LVd incremen taram seguindo uma equaçåo do segundo graú, em função da cala gem; 
12: A aplicação. de calcário elevou as pröduções de matéria seca da parte aérea do segundo corte, das raizes, da planta inteira e o peso seco dos nódulos da centrosema cultivada no solo LEa. Esses aumentos para a produçåo de matéria seća da parte aérea e da planta inteira e quantidade total de nitrogênio no segundo corte, obedeceram efeitos quadráticos, enquanto que para o peso seco das raízes e dos nódulos, nitrogênio tatal no primeiro corte foram lineares. Entretanto, quando a centrosema foi cul tivada no solo LVd, a calagem aumeñtou linearmente a produçåo de matéria seca na parte aérea e quantidades totais de nitrogênio no segundo corte, peso seco da planta inteira e dos nódulos;

13. Para a galactia cultivada em ambos os solos, a calagem incrementou linearmente as produções de matéria seca da parte aérea no segundo corte, nitrogênio total e nodula . çăo;

14. Os teores de macro e micronutrientes na parte aérea das leguminosas testadas sofreram variações significativas com a utilizaçăo de niveis de calagem;

15. A aplicaçåo de molibdênio resultou em efeitos positivos sobre a produçăo de matéria seca e quantidades totais de nitrogênio acumuladas na parte aérea da soja perene no primeiro corte quando cultivada no solo LEa;

16. 0 molibdênio proporcionou efeitos favoráveis sobre o. peso seco das raizes e teores e quantidades totais de nitrogênio acumuladas na parte aérea da centrosema cultiva da no solo LEa. Ao emprego conjunto de cobalto e molibdênio. corresponderam maiores acumulações de nitrogênio na parte aé rea do segundo corte dessa leguminosa. Para essa leguminosa 
cultivada no solo LVd, o molibdênio beneficiou a acumulação de nitrogênio no segundo corte;

17. 0 peso seco dos nódulos, da centrosema cultivada no solo LEa mostrou-expressivas respostas ao emprego de cobalto. O cobalto, na ausência da calagem, também favoreceu a produçåo de matéria seca da centrosema no solo LVd no primeiro corte;

18. Para galactia cultivada no solo LEa, o molibdênio incrementou a produçåo de matéria seca da parte aérea no segundo corte, da planta inteira, o peso seco dos nódulos e as quantidades totais de nitrogênio na parte aérea do primeiro corte. No solo LVd, o molibdênio elevou as produçōes de matéria seca e nitrogênio total no segundo corte dessa legumí nosa;

19. Á aplicação de molibdênio, na ausência . ou no nivel 1 de calagem, corresponderam teores mais elevados de nịtrogênio na matéria seca da parte aérea do segundo corte na galactia e na centrosema cultivadas no solo LVd;

20. Na ausência da calagem, o emprego de cobalto diminuiu os teores de nitrogênio na matéria seca do primei ro corte da parte aérea da soja perene cultivada no solo LEa e na centrosema no segundo corte cultivada no solo LVd;

21. A aplicaçåo dos micronutrientes (cobalto e molibdênio) elevou significativamente os conteúdos desses nutrientes nas três leguminosas estudadas. 


\section{REFERENCIIAS BIBLIOGRÁFICAS}

ACIOLY, J.C. 1982. Teores de $\mathrm{Na}, \mathrm{K}, \mathrm{Mg}, \mathrm{Ca}$ e $\mathrm{P}$ em gramineas coletadas em Fortaleza, Ceara. Ciência Agronômica, Fortaleza, $4(1,2): 17-23$.

AHAMED, S. \& H.J. EVANS 1960. Cobalt: a micronutrient element for the growth of soybean plants under symbiotic conditions. Soil Sci., Baltimore, 90: 205-210.

AGARWALA, S.C.; C.P. SHARMA; S.. FAROOR \& CHATTERJEE. 1978. Effect of molybdenum deficiency on the growth and metabolism of corn plants raised in sand culture. Can. J. Bot., Otawa, 56:1905-1908.

ALLAWAY, W. R. 1968. Agronomic controls over the environmental cycling of trace elements. Adv. Agron, New York, 20, 235-274. 
ANDERSON, A. J. 1956a. Molybdenum as a fertilizer. Advances in Agronomy, New York, 8: 163-202.

ANDERSON, A.J. 1956b. Molybdenum deficiencies in legumes in Australia. Soil Science, Baltimore, 81:173-258.

ANDERSON, A.J. \& R. H. ARNOTT. 1953. Fertilizer studies on basaltic red loom soil from the Lismore district, New South Wahas. Austr. J. Agric. Res., Melbourne, 4:29-43.

ANDREW, C.S. 1962. Influence of nutrition on nitrogen fixation on growth of legumes. In: Comittee of the Division of Tropical Pastures, CSIRO, Austrália, Ed. A review of nitrogen in the tropics with particular reference to pastures; a symposium. Farmham Royal, Bucks, Commowealth Agricultural Bureaux, p.130-146. Bulletim 46 .

ANDREW, C.S. 1978. Legumes and acid soils. In: DOBEREINER, J.; BORRIS, R. H.; HOLLAENDER, A. Limitations and potentials for biological nitrogen fixation in the tropics. New York, Plenum, p.137-57:

ANDREW, C.S. \& D.O. NORRIS. 1961. Comparative response to calcium of five tropical and four temperate pasture legume species. Austr. J. Agric. Res., Melbourne, 12:40-55.

ANDREW, C.S. \& M.F. ROBINS, 1969. The effect of phosphorus on growth and chemical composition of some pasture legumes. I. Growth and critical percentages of phosphorus Austr. J. Agric. Res., Melbourne, 20:665-674. 
AZEVEDO, G.P.C. \& F.R.S. de SOUZA. 1982b. Niveis de fósforo Pą ra adubação de pastagens de colonião ( $\underline{P}$. maximum) em Altamira. Pará. Anais da XIX Reunião Anual da Soc. Bras. Zootec., Piracicaba, 467p.

AZEVEDO, G.P.C. \& F.R.S. de SOUZA. 1982a. Fertilizantes para adubação de pastagens de capim colonião (ㅁ. $\underline{\text { maximum })}$ em Al tamira, Pará. Anais da XIX Reunião Anual da Soc. Bras. Zootec., CNPq, Piracicaba, 467p.

BARBER, S.A.; J.M. WALKER \& E:H. VASEY. 1963. Mechanism for the movement of plant nutrients from the soil and fertilizer to plant root. J. Agr. Food Chemi, II, 204-207.

BATAGLIA, O.C.; A.M.C. FURLANI; J.P.F. TEIXEIRA; P.R. FURLANI \& J.R. GALlo. 1983. Métodos de Análise Quimica de Plantas. Bol: Téc., IAC, Campinas, 78:1-48.

BLACK, C.A. 1968. Soil-plant relationships $\left(2^{\text {nd }}\right.$ ed.). John Wiley and Sons, New York.

BLOOMFIELD, C. 1981. The translocation of metats in soils. In: GREENLAND, D.J. \& HAYNES, M.H.B., eds. The Chemistry of Soil Processes, John Wiley \& Sons, New York, 463.

BRUCE, R.C. 1978. A review of the trace element nutrition of tropical pasture legumes in northern Australia. Trop. Grasslands, Brisbane, 12(3):170-183. 
BRUCE, R.C. \& TEITZEL, J.K. 1978. Nutrition of Stylosanthes, guianensis on two sandy soils in humid tropical lowland environment. Trop. Grassl., Brisbane, 12(1):39-48.

CAMARGO, O.A. \& B. VAN RAIJ. 1975. Relações entre o aluminio trocável, bases trocáveis e pH em solos. Anais do XV Con-. gresso Bras. de Ci. do Solo, pp.95-101.

CARVALHO, J.H.; R.H. HOUSER; K.R. FICK \& L.R.MCDOWEL. 1976. o cobalto na nutrição dos ruminantes. Simpósio Latino-Ame Iicano sobre Pesquisa em Nutrição Animal de Ruminantes em Pastagens - MG, 193-201.

CARVALHO, N.M.; A.B. CRUZ FILHO \& M. A. BOTREL. 1984. FOImação de Pastagens. In: CURSO DE PECUARIA LEITEIRA PARA TECNICOS DA NESTLE, 3., São Paulo. Neștlé, p.8-18.

CATANI, R.A. \& J.R. GALLO, 1965. Avaliação da exigência de calcário dos solos do Estado de São Paulo, mediante correlação entre o pH e a porcentagem de saturação em bases. Rev. Agric. Piracicaba, 30:49-60.

CENTRO INTERNACIONAL DE AGRICULTURA TROPICAL. 1977. TIOPical Pasture Program. Annual Report, Cali.

- CENTRO INTERNACional de AGRicultura tROPCiAl. Programa de Pastos Tropicales Informe, 1980, p. 57-68.

CHESNIN, L. 1972. In: "The Fertilizer Handbook" (W.C. White and D.N. Collins, eds.), pp.65-84. Fertilizer Institute, Washington, D.C. 
$f$ COLEMAN, N.T. \& E.W. THOMAS. 1967. The basic chemistry of soll acidity. In: PEARSON, R.W. \& ADAMS, F. SOil acidity and liming. Madison, American Society of Agronomy. p.1-41

COLEMAN, N.T. \&.W.A. JACKSON. 1960. Phosphate sorption reactions that envolve exchangeable aluminium. Soil Sci.,. Baltimore, Md, 90:1-7.

COLOZZA, M.T.; F.A. MONTEIRO; A.L. FANCELLI \& J.C. WERNER. 1987. Limitações de fertilidade em solos de três localidades do Estado de São Paulo para o cultivo da Galactia striata (Jacq.) Urb. B. Indústr. anim., Nova Odessa, SP, $\underline{44}(1): 135-45$, jan./jun.,

COLOZZA, M.T.; F.A. MONTEIRO,- J.C. WERNER \& A. L. FANCELLI. 1986. Limitações nutricionais em solos de cinco localida des paulistas para o cultivo de centrosema. $\underline{R}$. bras. Ci. Solo, Campinas, SP, 10:151-6, maio/ago.

COMASTRI FILHO, J.A. 1977. Variação de produtividade, diges tibilidade e composição química do capim elefante "Mineiro" (Pennisetum purpureum, Schum) com a sucessão de cortes e aplicação de nitrogênio, fósforo e potássio. Tese de Mestrado, Viçosa, MG, 51p.

COSTA ; G.G.; P.H. MONERATT; J.A. GOMIDE. 1983. Efeito dé doses de fósforo sobre o crescimento e teor de fósforo de capim-jaraguá e capim-colonião. Rev. Soc. Bras.Zootec_Viçosa, $M G, \underline{12}(1): 1-10$. 
COMISSAO DE SOLOS, 1960. Levantamento de Reconhecimento dos Solos do Estado de São Paulo. Centro Nacional de Ensino e Pesquisas Agronómicas. Boletim no 12, Rio de Janeiro.

COUTO, W.; C. SANZONOWICZ \& G.G. LEITE. 1982. Adubação no es tabelecimento de pastagens consorciadas nos solos dos cer rados. VI SIMPOSIO SOBRE O CERRADO, Brasilia, D.F:

DANTAS, H. S. 1971. Cobalto e complexo sortivo nos solos da uniidade Utinga. Pesq. agropec. bras., Rio de Janeiro, 6: $23-26$.

DANTAS, H.S. \& A. HOROWITZ. 1976. Determinação do molibdênio trocável em alguns solos de pernambuco. In: CONGRESSO BRASILEIRO DE CIENCIA DO SOLO, 15, Campinas, 1975: Anais. ... Campinas, SBCS, p:103-5.

DATE, R.A. \& G.R. HILLIER. 1968. Molybdenum application in the lime of lime-pelleted subterraneam clover seed. J. Austr. Inst. Agri Sci., Sidney, 34, 171-172.

DAVIES, E.B. 1956. Factors affecting molybdenum availability in soils. Soil Sci., Baltimore, 81(3):209-21.

DE POLLI, H.; A.R. SUHET \& A.A. FRANCO. 1976. Micronutrientes limitando a fixação de nitrogênio atmosférico e produ ção de centrosema en solo Podzólico Vermelho-Amarelo. In: CONGRESSO BRASILEIRO DE CIENCIA DO SOLO, 15, Campinas, 1975. Anais, Campinas, Sociedade Brasileira de Ciência do solo, 1976. p.151-156. 
DOBEREINER, J. \& S. ARONOVICH, S. 1966. Efeito da calagem e da Temperatura do Solo na Fixação de Nitrogênio de Centrose. ma pubescens, Benth. em solo com toxidez de manganês (SP). In: Congresso Internacional de Pastagens, 9, 1965. Anais. v.2p. $1121-4$. $^{-}$

EMPRESA BRASILEIRA DE PESQUISA AGROPECUÁRIA. 1976. Centro de Pesquisa Agropecuária dos Cerrados. Relatório, Anual, Brasilia, 1976, p.126.

EMPRESA BRASILEIRA DE PESQUISA AGROPECUÁRIA. 1980. Centro de Pesquisa Agropecuária dos Cerrados. Planaltina, DF. Rel. Téc. Anual, Cerrados. Planaltina. v.4, 170p.

EPSTEIN, E. 1975. Nutrição mineral das plantas: principios e perspectivas; trad. e notas de E. Malavolta. Rio de Janeiro, Livros Técnicos e Cientificos; São Paulo, Editora da Univ. Săo Paulo, $341 \mathrm{p}$.

EVANS, H.J. \& S.A. RUSSEL. 1971. Physiological chemistry of symbiotic nitrogen fixation by legumes. In: POSTAGE, J.R. ed. The Chemistry and Biochemistry of Nitrogen Fixation, Plenum Publishing Co., p. 191-244.

FALADE, J.A. 1975. The effect of phosphorus on the growth and mineral composition of five tropical grasses. $\underline{E} . \dot{A}$. Agric. For. ‥ Nairobi, 40:342-350.

FENSTER, H.E. e L.A. LEON. 1978. Management of phosphorus fertilization in establishment and maintaining improved pasture on acid, infertile soil of tropical America. In: SANCHEZ, P.A. e L.E. TERGAS, Ed. Pasture Production in Acid Soils of the Tropics. Cali, p. 109-122. 
FRANCO, A.A. \& J. DOBEREINER. 1971. Toxidez de manganês de um solo ácido na simbiose soja Rhizobium. Pesq. agropec. bras. Rio de Janeiro, 6: 57-66.

XFrança, G.E.; A.F.C. Bahia Filho \& M.M. CARValho. 1973a. Influência de magnésio, micronutrientes e calagem no desenvol vimento e fixaçăo simbiótica de nitrogênio na soja perene var. Tinaroo (Glycine wightii) em solo de cerrado. Pesg. agropec. bras., Rio de Janeiro, ㅌ: 197-202.

FRANÇA, G.E.; M.M. CARVALHO \& J.G. FERREIRA. 19974. Efeito de niveis de fósforo e calagem sobre o estabelecimento e produçåo de Hyparrhenia rufa (Nees) Stapf. Projeto Bovinos EPAMIG - Relatório Anual 73/74. Belo Horizonte, 144-148.

PFrançA, G.E. \& M.M. CARVALHO. 1970. Ensaio exploratório de fertilização de cinco leguminosas tropicais em um solo de cerrado. Pesq. agropec. biras., Rio de Janeiro, 5:147-153. FREUND, R.J. \& R.C. LITTEL. 1981. SAS for Linear Models.

Guide to the Anova and GLM Procedures. SAS Series in Statistical Applications. SAS Institute Inc., Cary, NC.

FRIES,L. 1962. Vinamini $B_{12}$ in Pisum sativum L. Phys, Plant, Lancaster, 15:566-571.

FOTH, H.D. 1978. Fundamentals of soil science. 6 ed. New York, John Wiley.

FOY, L.D. \& J. L. BROWN. 1963. Toxic factors in acid soils. I. Proc. Soil Sci. Soc. Amer., Madison, Wis, 27:403-7.

FOY, C.D. 1976. Differential Aluminum and manganese tolerances of plant species and varieties in acid soils. Ciência, e Cultura. Săo Paulo, 28:150-155. 
GALLO, J. R.; R. HIROCE; O.C. BATAGLIA; P.R. FURLANI; A.M.C. FURLANI; H.B. MATTOS; H.J. SARTINI \& M.P. FONSECA. 1974. Composição Quimica Inorgânica de Forrageiras do Estado de Såo Paulo. B. Indústr. anim., SP, 31(1):115-37, jan./jun. GARTNER, R.J.W.; R.W. MCLEAN; D.A. LITTLE and L. WINKS. 1980. Mineral deficiencies limiting production of ruminants grazing tropical pastures in Austrália. Tropical. Grasslands, Brisbane, 14:(3), November, 266-272.

GAVILON, O. \& A.T. QUADROS. 1970. O cálcio e o fósforo em pastagens nativas do Rio Grande do Sul: constataçăo de deficiênciäs na primavera e no verão. Boletim Técnico no 17. Governo do Estado do Rio Grande dọo Sul, Secretaria da Agri cultura, Departamento de Produção Animal, Porto Alegre. 17p. GLADSTONES, J.S.; J.F. LNERAGAN \& N.A. GOODCHILD. 1977. Field responses to cobalt and molybdenum by different legume species, with inferences on the role of cobalt in segume. growth. Austr. ‥ Agric. Res., Melbourne, 28:619-628.

GOMIDE, J.A. 1975. Adubação fosfatada e potássica das plantas forrageiras. Anais do II Simpósio sobre Manejo de Pastagem. ESALQ, CATI, AEASP, ORC, Piracicaba, 143-145p.

GOMIDE, J.A. 1976. Composição mineral das gramineas forrageiras tropicais. In: Simpósio Latinoamericano sobre pesquisa .:èm nutrição mineral de ruminantes em pastagens. Belo Horizonte, UFMG, UFV, ESALQ, EPAMIG, USAID. P. 193-201.

GUPTA, U.C. \& J. LIPSETT. 1981. Molybdenum in soils, plants and animals. Advances in Agronomy, New York, 34:73-115. 
GURLEY, W. H. \& J. GIDDENS. 1969. Factors affecting uptake, yield response, and carryover of molybdenum in $\because$ soybean seed. Agron. J. Madison, 617-9.

GUSS, A.; J.A. GOMIDE, \& P.H. MONERATT.: 1981. Modalidades de aplicação e de parcelamento de $P, 0$ sobre o .rendimento forrageiro e composição química do capim-jaraguá (Hyparhe. nia rufa (Nees) Stapf). Rev. Soc. Bras. Zoot., Viçosa, $\underline{10}(1): 19-26$.

HAAG, H.P:; M.L.V. BOSE \& R.G. ANDRADE. 1967. Absorção de ma cronutrientes pelos capins colonião, gordura, jaraguá, napier e pangola. Anais da E.S.A. "Luiz de Queiroz", Piracicaba, XXIV: 177-188.

HALL, R.V.L. 1970. Pasture development in the spear grass region at Westwood in the Fitzroy Basin. Trop.Grassland, Brisbane, $4: 77-84$.

HARRIS, H.B.; M.B. PARKER \& B.J. JOHNSON. 1965. Influence of molybdenum content of soybean seed and other factors associated with seed source on progeny response to applied molybdenum. Agron. J., Madison, Wis, 57: $397-9$.

H.OROWITZ, A. 1978. Os íons do molibdênio no solo - um exemplo da aplicação dos diagramas Eh-pH. Rey. Bras. Ci. Solo, Campinas, $\underline{2}(2): 98-103$.

HOROWITZ, A. \& DANTAS, H:S. 1966. Geoquímica dos elementos menores nos solos de Pernambuco. I. Manganês na zona da mata e do Sertão. Pesq.. agropec. bras. Rio de Janeiro, 1: 383-390. 
ITALIANO, E.C. \& J.R. da SILVA. 1982. Rendimento forrageiro e composição quimica do capim quicuio da Amazônia em diferentes estádios de crescimento no periodo chuvoso. Anais da XIX Reunião Anuial da Soc. Bras. Zootec., CNPq, Piracicaba, 457p.

ITALIANO, E.C.. E. de MORAES, \& E.A. C. de CANTO, 1982b. Ma cronutrientes e FTE em pastagens de capim colonião em degradação. Anais da XIX Reunião Anual da Soc. Bras.Zootec. CNPq, Piracicaba, 467p.

JACKSON, W. A. 1963. Aluminium bonding in soils: a unifying principle in soil science. Proc. Soil Sci. Soc. Amer. Ma dison, Wis, $27: 10-5,1963$.

JARDIM, W.P.; A.M. PEIXOTO, \& C.L. MORAIS. 1962. Composição Mineral de Pastagens na Região de Barretos, no Brasil Cen tral. Bol. Técn. Cientifico, ESALQ, Piracicaba, 11:1-11.

JARDIM, W.R.; A.M. PEIXOTO; C.L. MORAIS \& F. SILVEIRA. 1966. Estudo da composição química das plantas forrageiras de pastagens do Brasil Central. Anais do IX Congresso Inter nacional de Pastagens - SP, 699-706.

JENSEN, H.L. 1948. Nitrogen fixation in leguminous plantas. VII The nitrogen fixing activity of root nodule tissue in Medicago and Trofolium. Proceedings of the Linnean So ciety of New Wales, 68:1-8. 
JENSEN, H.L.V. \& R.C. BETTY. 1943. Nitrogen fixation in leguminous plants. III. Importance of molybdenum in symbiotic nitrogen fixation. Proceedings of the Linnean. Society of New South Wales. 68:1-8.

JOHANSEN, C.; P.C.KERRIDGE, P.E. LUCK; E.G.COOK; K.L. LOWE \& H. OSTROWSKI. 1977. The residual effect of molybdenum fertilizer on growth of tropical pasture legumes in a sub tropical environment. Austr. 3. Exp. Agric. Anim. Husb, Melbourne, 17(89): 961-968.

JONES, R.K. 1968. Initial and residual effects of superphosphate on a Townsville lucerne pasture in north- eastern Queensland. Austr. J. Exp. Agric. Anim. Husb, Melbourne, Vic., $8=52 \cdot 1-527$.

JONES, R.K. 1974. A study of the phosphorus responses of a wide range of accessions from the genus Stylosanthes. Aus tr. J. Agric. Res., Melbourne, 25: 847-62.

JONES, M.B.; QUAGLIATO, J. L.; FREITAS, L.M.M. 1970. Respostas de alfafa e algumas leguminosas tropicais a aplicação de nutrientes minerais, em três solos de campo cerrado. Pesq. Agropec. bras., Rio de Janeiro, 5:209-214.

JUNQUEIRA NETTO, A.; 0.S. SANTOS; H. AIDAR \& C. VIEIRA. 1977. Ensaios preliminares sobre a aplicação de moliboênio e de cobalto na cultura do feijão (Phaseolus vulgaris L.) Rev. Ceres, Viçosa, 24(136):628-633. 
KABATA, A. \& K. BEESON. 1961. Cobalt uptake by plants from cobalt impregnated soil minerals. Soil Sci., Baltimore, 25: $125-127$.

KABATA-PENDIAS, A. \& H. PENDIAS. 1984. Trace elements in soils and plants. Boca Rạton, Flórida, CRC Press, Inc, 259p.

KAMPRATH, E. J. 1970. Exchangeable aluminum as a criterion for liming leeched mineral soils. Proc. Soil Sci. Amer., Madison, $34: 252-4$.

KAMPRATH, E. J. 1972. Soil acidity and liming. In.COMMITTEE ON TROPICAL SOILS. SOils of the humid tropics, Washington, D.C., National Academy of Sciences. p. 136-49.

KANNAN, S. \& S. RAMANI: 1978. Studies on molybdenum âdsorption and transport in bean and, rice. Plant Physiol. Lancas ter, P.A. 62:179-181.

KERRIDGE, P.C.; B.G. COOK \& M. L. EVERETT. 1973. Application of molybdenum trioxide in the seed pellet for sub-tropical pasture legumes. Trop. Grassld., Brisbane, Qd., ㅍ: (2) :229-32.

KERRIDGE, P.C.; C.S. ANDREW \& G.G. MURTHA. 1972. Plant nutrient status of soils of the Atherton Tableland, North Queensland. Austr. J. Exp. Agric. Anim. Husb., Melbourne, $12: 618-27$. 
KLIEWER, M. \& H. J. EVANS. 1963. Cobamide coenzyme contents of soybean nodules an nitrogen fixing bacteria in relation to physiological conditions. Pl. Physiol., Lancaster, 38:99-104.

LEHNINGER, A. L. Biochemistry. Worth Publishers, Inc., New York, 1970.

LINDSAY, W. L. 1972. Inorganic phase equilibria of micronutrients in soils In: MORTVEDT, J. J.; P. M. GIORDANO; W. L. LIND - Micronutrients in agriculture. Madison; Soil Science Society of America. p. 41-57.

LIPSETT, J. \& D.J. DAVIS. 1977. Amount and distribution of molybdenum in a bag of molybdenized superphosphate. … Aust: Inst. Agric. Sci., Sidney, 43:149-151.

LOPES, A.S. 1984. Uso eficiente de fertilizantes com micronu trientes. In: SIMPOSIO SOBRE FERTILIZANTES NA AGRICULTURA BRASILEIRA, Brasilia, 1984. Anais... Brasilia, EMBRAPADEP. Documentos, 14, p. 347-382.

LOTERO, J.; S.A. MONSALVE; A. RAMIREZ \& F：VILLAMIZAR. 1971. Respuesto de gramineas y leguminosas forrajeras al encalamiento. Suelos Equatoriales, 3:210-39.

WOVADINI, L.A.C. 1972. Comportamento da soja perene. (Glycine wightii Verdc) em solos ácidos, em função das variações de $\mathrm{pH}$, Al trocável e do fósforo aplicado como fosfato so lúvel. Piracicaba, ESALQ/USP, 94p. (Tese de Doutoramento) 
LUCK, P.E. \& N. J. DOUGLAS. 1966. Dairy pasture research and development in the near North Coast centred on Cooray, Queensland. The Tropical Grassaland Society of Australia, Proceedings no $6,35-60$.

MACKAY, D.C.; E.W. CHIPMAN \& V.C. GUPTA. 1966. Copper and molybdenum nutrition of crops grown on acid. sphagnum ipeat soil. Proc. Soil Sci. Soc. Amer., Madison, 30:.755759 .

MAC PHERSON, A.; F.E. MOON and.R.C. VOSS. 1973. Some effects of feeding young steers with a diet deficient both cobalt and cupper. Britisk Veterinary Journal, London, 129:414425 .

MALAVOLTA, E. 1976. Manual de química agrícola: nutrição de plantas e feitilidade do solo. São Paulo, Ed. Agronômica. "Ceres", $528 \mathrm{p}$.

MALAVIOLTA, E.; G.C. VITTI \& S. A. OLIVEIRA, 1989. Avaliação do Estado Nutricional das Plantas: Principios e Aplicações. Associação Brasileira apra Pesquisa da Potassa e do Fosfato, $201 \mathrm{p}$.

MALAVOLTA, e.; H.P..HAAG; F.A.F. MELLO \& M.O.C. BRASIL SOBRI NHO, 1974. Nutrição mineral e adubação de plantas cultivadas Liv. Pioneira Ed., São Paulo, 727 p.

MALAVOLTA, E.; J.R. SARRUGE; V.C. BITTENCOURT. 1977. Toxidez de alumínio e de manganês. In: SIMPOSIO SOBRE 0 CERRADO, 4., Brasilia, DF., 1976. IV Simpósio sobre o 
bases para utilizaçăo agropecuária, coord. Mário Ġ. Ferrí. Belo Horizonte, Ed. Itatiaia; Săo Paulo, Ed.Universidade de Såo Paulo, 1977 p. 275-301.

MANNETJE, L.'t; N.H. SHAW \& T.W. ELICH. 1963. The residual effect of molybdenum fertilizer on improved pastures on a prairie-like soil in subtropical Queensland. Austr. ․․ Exp. Agric. Anim. Husb., Melbourne, 3:20-25. MARTINEZ, H.E.P. \& H.P. HAAG. 1980. Niveis criticos de fósforo -em Brachiaria decumbens (Stapf).Prain) Brachiaria humidicola (Rendle) Schweickerdt, Digitaria decumbens (Stent), Hypar rhenia rufa (ness) Stapf), Melinis minutiflora (Pal de Beauv.), Panicum maximum (Jacq.) e Pennisetum purpureum Schum. Anais da E.S.A. "Luiz de Queiroz", .. Piracicaba, 37 (2) : 913-977.

MATTOS, H.B. \& J.C. WERNER. 1972. Efeito da Aplicação de Nutrientes Minerais em Galactia striata cultivada em um solp de Nova Odessa, In: Anais da IX Reuniăo da Sociedade Bras. Zootec., Viçosa, p. 261-262.

McKENZIE, R.M. 1975. Soil cobalt. In: NICHOLAS, D.J.O. \& EGAN, A.R. eds. Trace Elements in Soil Plant-Animal Systems, Lon don, Academic Press, P. 83-93.

MCLACHLAN, K.D. 1955. Phosphorus, sulphur, and molybdenum deficiencies in soil from eastern Austrália in relation to nutrient supply and some characteristics of soil climate. Austr. 3. Agric. Res., Melbourne, 6 :673-84.

MEAGHER, W.R.; C.M. JOHSON \& P.R. STOUT. 1952. Molydbenum requirement of leguminous ,plants supplied with fixed nitrogen. Plant. Physiol. Lancaster, 27:223-30. 
MEARS, P.T. \& B. BARKUS. 1970. Response of Glycine - wightii, to molybdenized superphosphate on a krasnozem. Austr. J. Exp. Agric. Anim. Husb., Melbourne, 10:415-25.

MELLO, F.A.F., 1985. Origem, natureza e componentes de acidez do solo: critérios de calagem. In: E. MALAVOLTA, coond Seminário sobre corretivos agrícolas, Piracicaba, Fundação cArgill, 375 p. 1984.

MENGEL, K. \& E.A. KIRKBY. 1982. Principles of plant nutrition. International Potash Institute. Worblaufen- BernSwitzerland. 593 p.

MITCHELL, R.L. 1962. Trace elements in soil. In: BEAR,F. E. ed. Chemistry of the Soil.-New York, Reinhold. Publishing Corporation, p. 320-368.

MONTEIRO, F.A.; H.B. MATTOS \& J.M. CARRIEL: 1980. Peletização de sementes de leguminosas forrageiras. I. Efeitos de micronutrientes e fontes de fósforo e cálcio em siratro. B. Indústr. anim., Nova Odessa, SP, 37(1):159-171.

MONTEIRO, F.A. \& J.C. WERNER. 1977. Efeito das adubações nitrogenada e fosfatada em cápim colonião, na formação e em pasto estabelecido. Bol. Indústr. animl., Nova Odessa, 34 (1):91-101.

XMonteiro, F.A. 19ִ8̣o. Efeitos da aplicação de micronutrientes e de ñiveis de calagem em quatro leguminosas tropicais. Te se de Mestrado. Piracicaba, SP, Escola Superior de Agricul tura "Luiz de Queiroz". 146 f. Mimeo. 
MONTEIRO, F.A.; M.T. COLOZZA, J.C.' WERNER \& S.A.A.L.- SAVASTANO. 1987. Limitações de fertilidade em solos de quatro localidades paulistas para o cultivo do siratro. R. bras. Ci. solo, Campinas, 11:175-181.

MUNNS, D.N. 1965. Soil acidity and growth of a legume. II. Reaction of aluminium and phosphate in solution and effects of aluminium, phosphate, calcium and $\mathrm{pH}$ on Médicago. sativa L. and Trifolium repens. L. in solution culture. Austr. J. Agric. Res., Melbourne, Vic., 16:745-55.

MUNNS, D.N. 1970. Nodulation of Medicago sativa in solution culture. V. Calcium and $\mathrm{pH}$ requirements during infection. Pi. Soil, The Hague, 37:90-102.

MUNNS, D.N. \& A.L. FOX. 1977c. Comparative line requirement of tropical and temperate legumes. Pl. Soil, Hague, 46: 533-548.

MUNNS, D.N. \& A. L. FOX. 1977. Influence of lime on nitrogen fixation by tropical and temperate legumes. Pl. Soil. Hague, 46:591-601.

MURPHY, L.S. \& L.M. WALSH. 1972. Correction of micronutrient deficiencies wi.th fertilizers. In: MORTVEDT, J. J.; P.M. GIORDANO \& W.L. LINDSAY, 1972. Micronutrients in Agriculture, Soil Sci. of America, Inc, pp. 347-388.

NASCIMENTO JUNIOR, D.; F.C. da SILVA \& J. DOS SANTOS PINHEIRO, 1976. Teores de alguns minerais do capim jaraguá (Hy 
parrehenia rufa (Ness) Stapf) em várias idades de cortie. Rev. Soc. Bras. Zoot., Viçosa, $\underline{5}(1): 48-55$.

NATIONAL ACADEMY OF SCIENCE. 1970. Nutrient requirements of domestic animals, no 4. Nutrient Requirements of Beef Cattle. National Research Council. Washington, D.C.Fourth Revised Ed.

NICHOLAS, D.J.D. 1975. In: Trace Elements in Soil- PlantAnimal System (D.J.D. Nicholas and A.R. Egan, eds.) Pp. 181-198. Academic Press, New York.

NORRIS, D. 0. 1959. The role of calcium and magnesium in the nutrition of Rhizobium. Austr. J. agric. Res.. Melbourne, $\underline{10}: 651-696$.

OSTROWSKI, H. 1970: Molybdenized superphosphate requirement for pasture establishment on red forest soils in subtropical Queensland. Procedings of the XI International Grassland Congress, Surfers Paradise, Australia: 124-26.

OSTROWSKI, H.; A. DIATLOFF \& H.R. WILLIAMS. 1978. Molybdenum responses of Siratro (Macroptilium atropurpureum) on a red volcanic soil in coastal south east Queensland.Trop. Grasslands, Brisbane, 12:75-79.

PATE, J.S. 1977. Functional biology of dinitrogen fixation by legumes. In: HARDY, W.F. \& W.S. SILVER, eds. A Treatese on Dinitrogen Fixation. III. Biology, New York, J. Wiley, P. 473-518. 
PATERSON, J.W. 1965. The effect of aluminum on the adsortion and translocation of calcium and other elements in young corn stock. Diss Abstr., Ann Arbor, Mich., 25:61423.

PAULINO, V.T.; M.T: COLOZZA \& H.B. MATTOS. 1985. Limitaçס̃es nutricionais de um Latossolo Vermelho-Escuro álico para o cultivo de cudzu-tropical. Zootecnia, Nova Odessa, SP, $23(1): 49-67$.

PEDROSA, F.O.; A.J. NASCIMENTO; R. ALVAHYDO \& J. DOBEREINER. 1970: Teores de leghemoglobina e de molibdênio nos nódu los de soja (Glycine max) (1.) Merril) inoculada com estírpes de Rhizobium japonicum de eficiência normal e exce pcional. Pesq.agropec. bras., 2:373-379.

PEREIRA, J.A.; D.J. SILVA; J.M. BRAGA \& J. CAMPOS. 1971. Teo . res de fósforo, cobre e cobalto em algumas pastagens do municipio de Teófilo Otoni, MG, Experimental, Viçosa, 12: 155-188.

PRÓSPERO, A.O. \& A.M. PEIXOTO, 1972. Composição mineral do capim elefante (Pennisetum purpureum, Schum) variedade napier, em diferentes estádios de desenvolviemnto. 0 soLO, Piracicaba, LXIV (2):45-51.

QUAGGIO, J.A. 1983. Critérios para calagem em solos do Estado de São Paulo. Dissertação apra obtenção do título de mestre em Agronomia, Esc. Sup. Agric. "Luiz de Queiroz". 
Ұ. QUAGLiato, J. L. \& P. NUTI. 1969. Efeito da calageme - micronutrientes e nutrientes na produção de leguminosas forrageiras, em solos de cerrado. In: 10 Encontro de Técnicos da Regiåo Centro-Sul para Discussåo de Problemas Relacionados às Leguminosas Forrageiras, Nova Odessa, 3 p.

RAIJ, B. VAN. 1981. Avaliação da Fertilidade do Solo. T. YAMADA (ed.), Instituto de Potassa \& Fosfato, Piracicaba, SP.

RAIJ, B. VAN \& J. A. QUAGGIO. 1983. Métodos de Análise de Solo para Fins de Fertilidade. Bol. Téc., IAC, Campinas, 81: 1-31.

RAIJ. B. VAN; M. T. D. SACCHETO \& T. IGUE. 1968. Correlações entre o pH e o grau de saturaçăo em bases nos solos com horizonte B textural e horizonte B latossólico. Bragantia, Campinas, 27: 193-200.

REISENAUER, H. M. 1960. Cobalt in nitrogen fixation by a legu me. Nature, London, 186:375-376.

REISENAUER, H. M. 1963. The effect of sulfur on the absorption and utilization of molybdenum by peas. Proc. Soil. Sci. Amer., Madison, 27:553-555.

REISENAUER, H. M; A. A. TABIKH E P. R. STOUT. 1962. Molybdenum reactions with soils and hydrous oxides of iron, aluminum, and titanum. Proc. Soil Sci. Soc. Amer., Madison, 26: 23-7. 
RORISON, I.H. 1958. The effect of aluminium on legume nutrition. In. HALLS-WORTH, E.G., ed. Nutrition of the legumes. London. Butter-worths. p.43-61.

SALINAS, J.G. 1978. Differential response of some

cereal and bean cultivars to $A l$ and $P$ stress in an oxisol of Central Brazil. PhD. Thesis North Carolina State on University, Raleigh. (Libr. Congr. Card No. Mic. LD 3921 Soil Sci. S12) $326 \mathrm{p}$.

X SALINAS, J.G. \& P.A. SANCHEZ. 1976. Soil Plant Relationship's -Affecting VArietal and Species Differences in Tolerance to How Available Soil Phosphorus. Ci. Cult.; São Paulo, 28: $156-168$.

SANCHEZ, P.A., 1976. Properties and Management of Soils in the Tropics: New York, wiley, Intứscience Publications. 618p.

SANCHEZ,P.A. 1982. Estrategia de Produccion de Pasturas a Base de Leguminosas en America Tropical. Instituto Nacional de Investigacion y Promocion Agropecuaria, Yurimaguas, Peru.' séria de Separatas no 11, 42p.

SANTOS, D.S.; V. ESTEFANEL; R. P. CAMARGO; A. ZAGO; A.D.M. TRINDADE; E.F. REGINATTO \& L.C.S.WEISS. 1986. Efeito da aplicação de Mo e de $Z n$ em sementes de soja sobre o teor desses nutrientes. In: soja-relatório de pesquisa do Centro de Ciências Rurais. Santa Maria, UFSM-FATEC, 1986. P. 39-44. 
SANZONOWICZ, C.; E. LOBATO \& W. J. GOEDERT. 1987. Efeito Residual da Calagem e de Fontes de Fósforo numa Pastagem Estabe lecida em Solo de Cerrado. Pesq. Agropec. Bras., Brasilia, DF, 22(3):233-243, imar.

SARRUGE, J. R. \& P. H. HAAG. 1974. Análises Químicas em Plantas. Piracicaba, ESALQ/USP. 27 p.

SAS. 1982. SAS User's Guidi: Basics, 1982. Ed. SAS, Institute Inc., Cary, NC.

SENESI, N. \& M. POLEMIO. 1981. Trace element addition to soil bu application of NPK feetilizers. Fert. Res., The Hague, 2:289-302.

SERRÃO, E. A. S.; I. C. FALESI; J. B. VEIGA \& J. F. TEIXEIRA NETO. 1979. Producitivity of cultivated pastures on low fer tility soil of the Amazon of Brazil. In. SANCHEZ, P. A. \& L. E. TERGAS, ed. Pasture production in acid soils of the tropics. Cali, CIAT, p. 195-225.

SHAW, N. H.; C. T. GATES \& J. R. WILSON. 1966. Growth and chemical composition of Townsville lucerne (Stylosanthes humi1is) 1. Dry matter yield and nitrogen contents in response to superphosphate. Austr. J. Exp. Agr. Anim: Husb. Melbour $n e, \underline{6}: 150-156$.

SIQUEIRA, C. \& A. C. VELOSO. 1978. Adsorção de molibdato em so los sob vegetação de cerrado: R. bras. Ci. Solo, Campinas, $S P, 2: 24: 8$.

SIQUEIRA, C.; M. M. de CARVALHO; O. F. SARAIVA \& F. T. T. OLIVEIRA. 1980. Respostas de três gramineas forrageiras tropicais à aplicação de calcário e fósforo em ụm solo ácido. In: CONGRESSO BRASILĖIRO DE ZOOTECNIA, 1., Fortaleza, 1980. Anais... Viçosa, Sociedade Brasileira de Zootecnia, 1980, P. 473. 
SMITH, F. W. 1975. Tissue testing for assessing the phosphorus status of green panic, buffel grass and setaria. Austr. J. Agric. Anim. Husb., Melbourne, 15(74):383-90, june.

SOARES, W. V. \& M. A. T. VARGAS. 1974. Ensaio exploratório de fertilização com duas leguminosas tropicais em três solos sob cerrado do Distrito Federal. In: CONGRESSO BंRASILEIRO DE CIÊNCIA DO SOLO, 14, Santa Maria, 1974. Anais. p.448-50.

SOUTO, S. M. \& DOBEREINER, J. 1968. Efeito do fósforo, tempera tura e umidade do solo na nodulação e no" desenvolvimento de duas variedades de soja perene. Pesq. Agropec. Bras., Rio de Janeiro, 2: $215-221$.

SOUZA, J. C.; J. H. CONRAD; W. E. BLUE \& L. R. MCDOWELL. 1979. Inter-relações entre minerais no solo, plantas forrageiras e tecido animal. I - Cálcio e fósforo. Pesq. Agropec. Bras., Brasilia, 14(4):387-395.

SPAIN, J. M. 1979. Pasture establishment" and management in the Llanos Orientales of Colômbia. p. 167-176. In: P. A. SANCHEZ and L. E. TERGAS (ed.). Pastures production in acid soils of the tropics. Centro. Internacional de Agricultura Tropical, Cali, Colômbia.

SPAIN, J. M.; C. A. FRANCIS; R. H. HOWELER and F. CALVO. 1975. Differential species and varietal tolerance to soil acidity in tropical crops and pastures. In\& BORNEMISZA, E. \& A. ALRADO, ed. Soil mamagement in tropical America., Cali, CIAT, 1975. p. 308-29. 
SWAIN, F.G. 1959. Responses to molybdenum three years after previous application on red basaltic soil on the far North Coast of N.S.W. J. Austr. Inst. Agric. Sci., Sidney, 25:51-54.

TAYLOR, R.M. \& MCKENZIE, R. M. 1966. The association of trace elements with manganese minerals in . Australian soil. Austr. J. Soil Res., Melbourne, 4:29-39:

TIFFIN, L.0. 1972. Translocation of micronutrients . in plants. In: MORTVEDT, J.J.;.P.M. GIORDANO \& W.L. LINDSAY, eds. Micronutrients in Agriculture. Madison, Soil Science Society of America, Inc., p.199-229.

TISDALE, S. \& W. NELSON. 1975. Soil Fertility and Fertili-. zers. MacMillan Publishing Co.., Inc. 673p.

TOKARNIA, C.H. 1981. Deficiências de cobalto em bovinos na Serra da Ibiapaba, no Estado do Ceará. Arg Inst. Biol. Anim., Rio de Janeiro, 41:195-202.

TOKARNIA, C.H.: \& J. DOBEREINER, 1976. Doenças causadas por deficiências em bovinos em regime de campo no Brasil. In: Simpósito Interamericano sobre pesquisa mineral de pastagens. Belo Horizonte, UFMG, UFV, ESALQ, EPAMIG e USAID, p.116-129. 
UNDERWOOD, E..J. 1966. The Mineral Nutrition of Livestock. P. 150 (FAO, Rome).

VARGAS, M. A. T. \& J. DOBEREINER. 1974. Efeito de niveis crescentes de calagem, manganês, magnésio e bơro na simbiose e desenvolvimento vegetativo de Stylosanthes. guianensis. Pesq. Agropec. Bras., Rio de Janeiro, 9:21-28.

VICENTE-CHANDLER, J.; R. CARO-COSTAS; R. W. PEARSON, F. ABRUNA; J. FIGARELLA \& S. SILVA. 1964. The intensive management of tropical forages in Puerto Rico. Univ. Porto Rico, Rio das Piedras, Puerto Rico, 149 p.

VIDOR, C. \& J. R. J. FREIRE. 1972. Controle de toxidez de alumínio e manganês em Glycine max (L.) Merrill pela calagem e adubação fosfatada. Agron. Subiogi, $\underline{8}(1): 73-87$.

VINOGRADOVA, K. L. G. 1943. Presence of molybdenum in Leguminosae. Doblady Akademii Naub S.S.S.R. 40:26-9.

WERNER, J. C. 1984. Adubação de.Pastagens. Bol. Téc. no 18. Instituto de Zootecnia, Nova Odessa, SP, 49 p. 
WERNER, J.C. 19.75. Uso de micionturientes em pastagens. In: SIMPOSIO SOBRE MANEJO DA PASTAGEM, 2., Piracicaba, SP., Escola Superior de Agricultura "Luiz de Queiroz", 1975. P.87-111.

WERNER, J.C.; E.B. KALIL; F.P. GOMES; J.V.S.' PEDREIRA; G.L. ROCHA; H.J. SARTINI, 1968. Competição de adubos fosfata dos. Bol. Indústr. Anim., SP, 25:139-49.

WERNER, J.C.; F.A. MONTEIRO, \& H.B. MATTOS. 1975a. Emprego de micronutrientes na forma de elementos traços fundidos (F.T.E.) em leguminosas forrageiras tropicais. Bol. Ind. anim., Såo Paulo, 32:347-361.

WERNER, J.C. \& H.B. MATTOS: 1974. Ensaio de fertilização com alguns micronutrientes em soja peṛene, $\cdot{ }^{\prime}:$ Glycine wightil, willd. Bol. Indústr. anim., Såo Paulo, 31:31324.

WERNER, J.C. \& H;B. MATTOS. 1975. Ensaio de fertilizaçåo com quatro micronutrientes em Centrosema pubescens Benth. B. Indústr. anim., Nova Odessa, 32(1):123-35.

WERNER, J.C. \& H.B. MATTOS. 197.2. Estudo de nutrição da cen trosema, Centrosema pubescens, Benth. B. Indústr. anim., : Såo Paulo, 29:375-391.

WERNER, J.C. H.P. HAAG. 1972. Estudos sobre a nutrição mine ral de alguns capins tropicais.

B. Indústr. anim. Nova Odessa, SP, 29(1): 191-245. 
WERNER, J.C.; J.L. QUAGLIATO \&.D. MARTINELLI. 1967. EnSalO de fertilização do coloniăo com solo da "noroeste". B. Indústr. anim., Nova Odessa, SP, 24 (ne único):159-167.

WILSON, D.O. \& H.M. REISENAUER. 1967. Cobalt requirement of symblotically grown alfata. Plant and Soll, Hague 19:364373.

WOODHOUSE,Jr., W.W. 1964. Nutrient deficiencies in forage gfasses. In: HUNGER SIGNS IN CROPS, a symposium, New York, David Mackay, Company, U.S.A. p.181-218. 
A P E N D I C E 


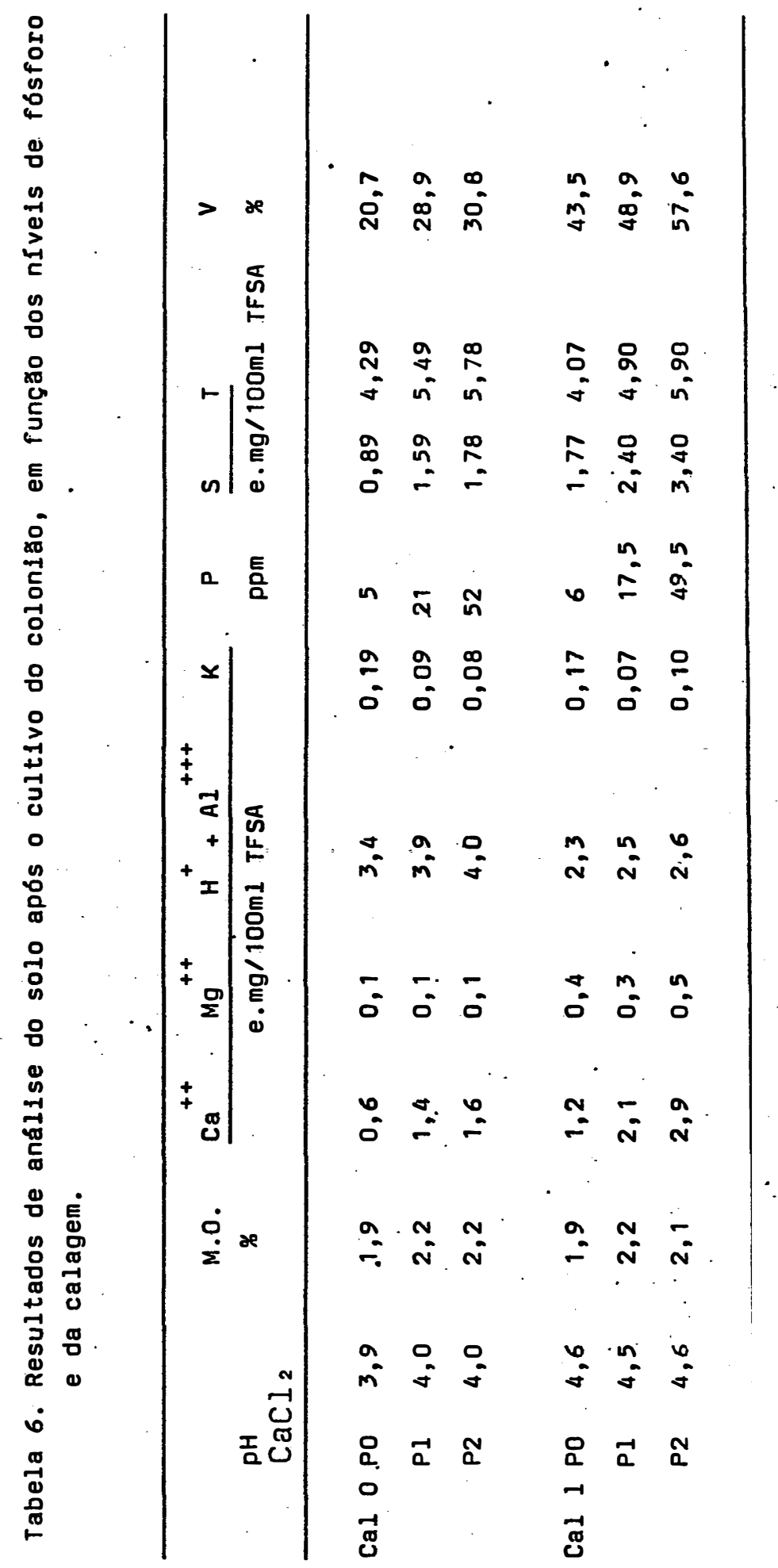




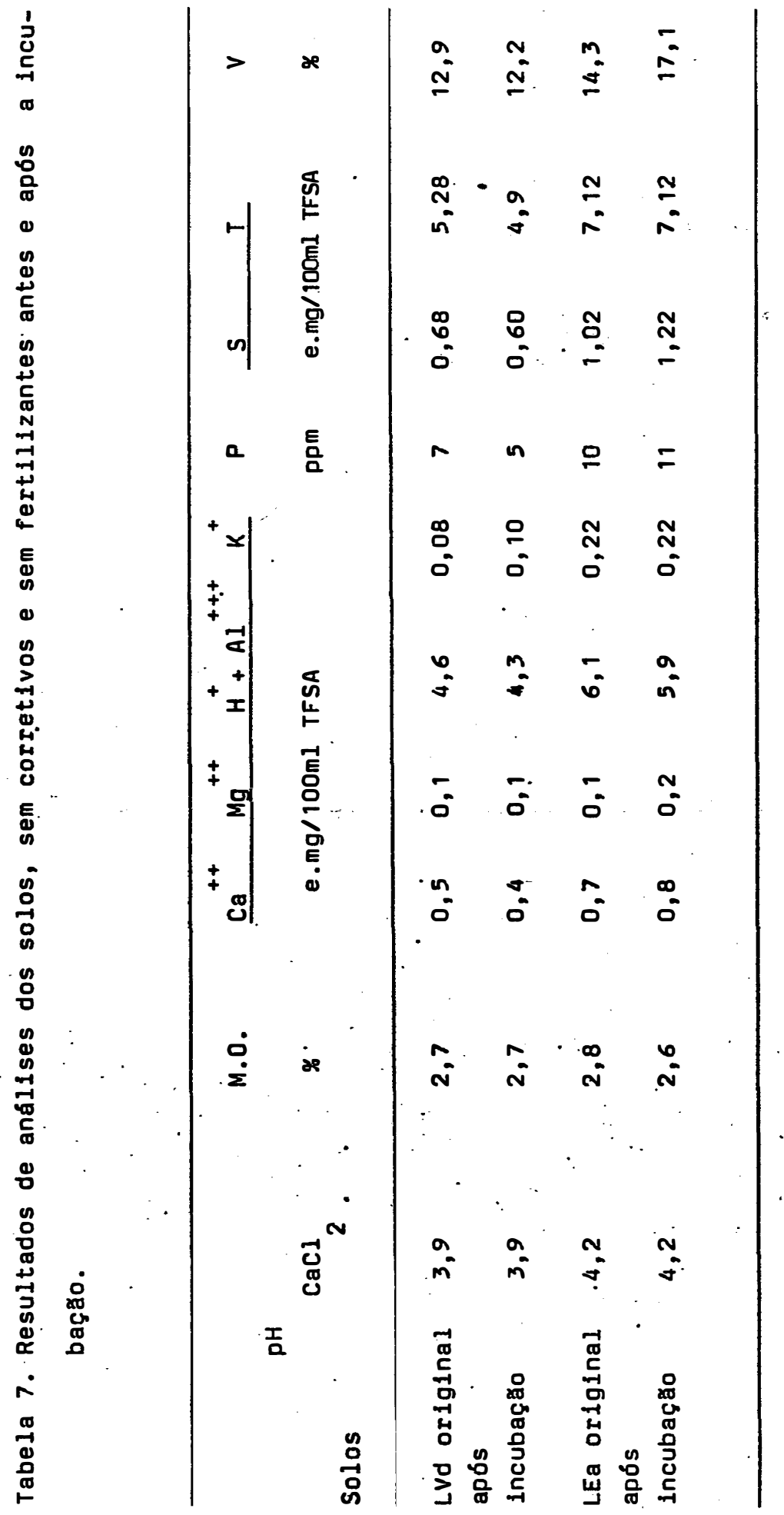




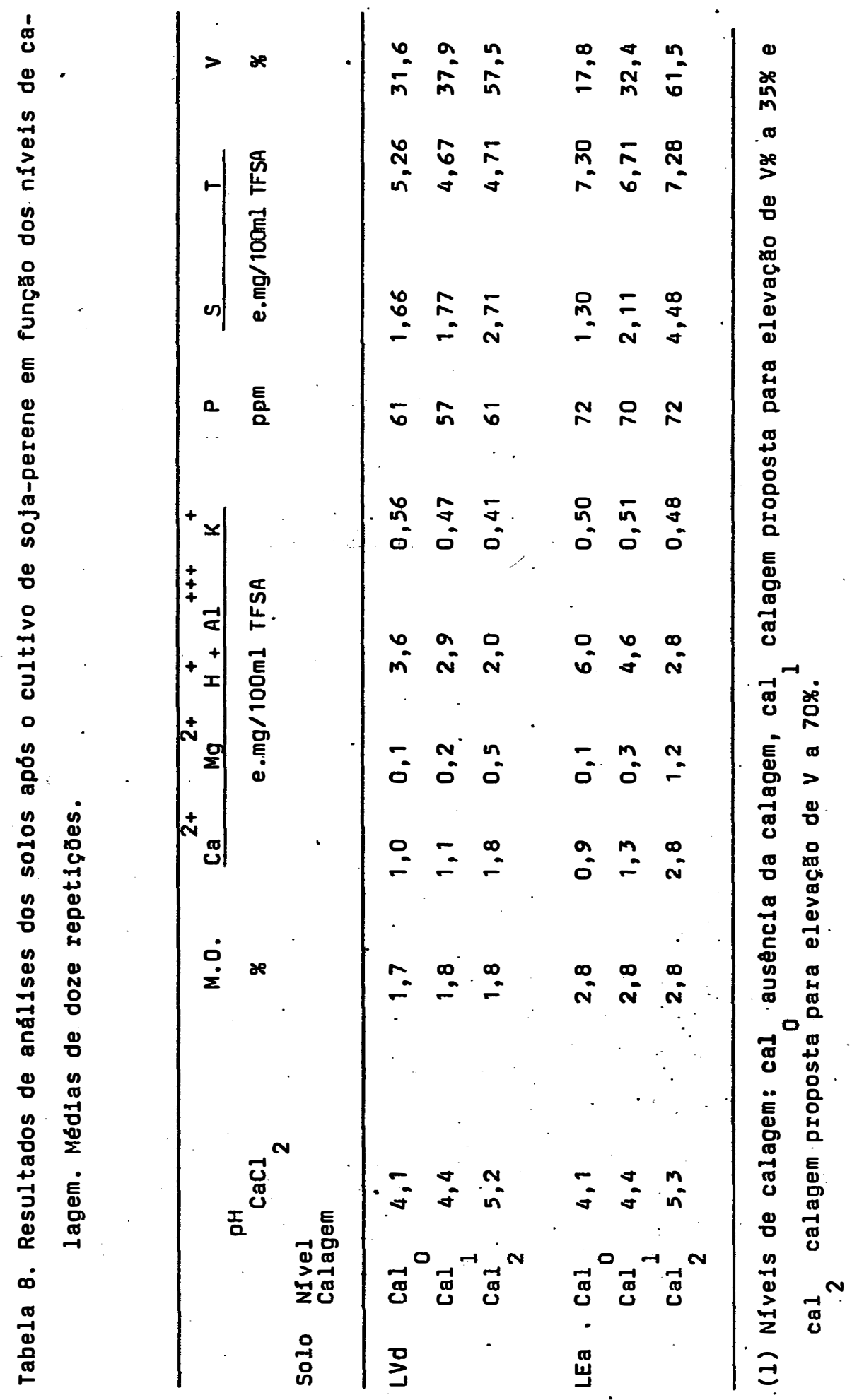




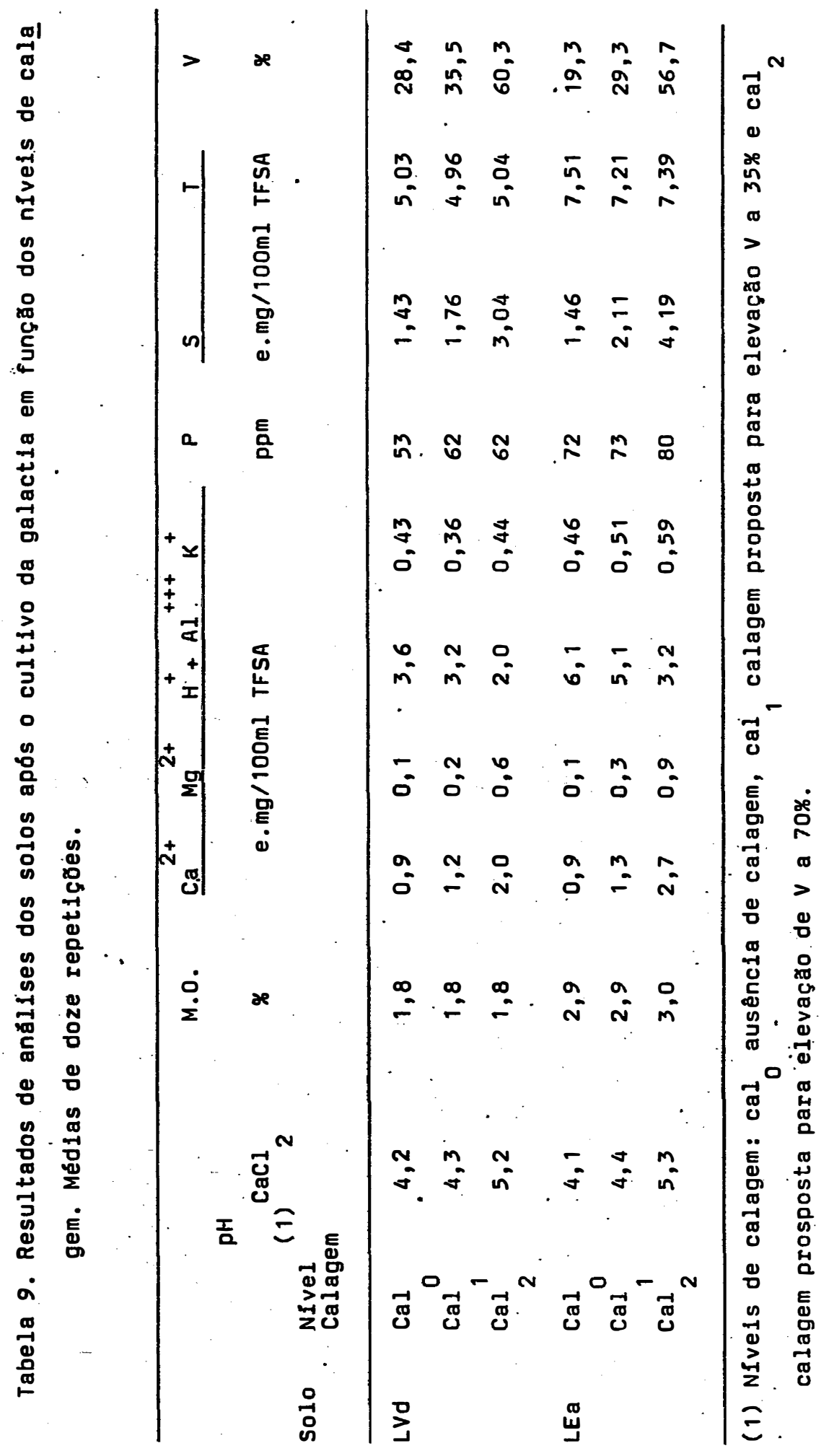




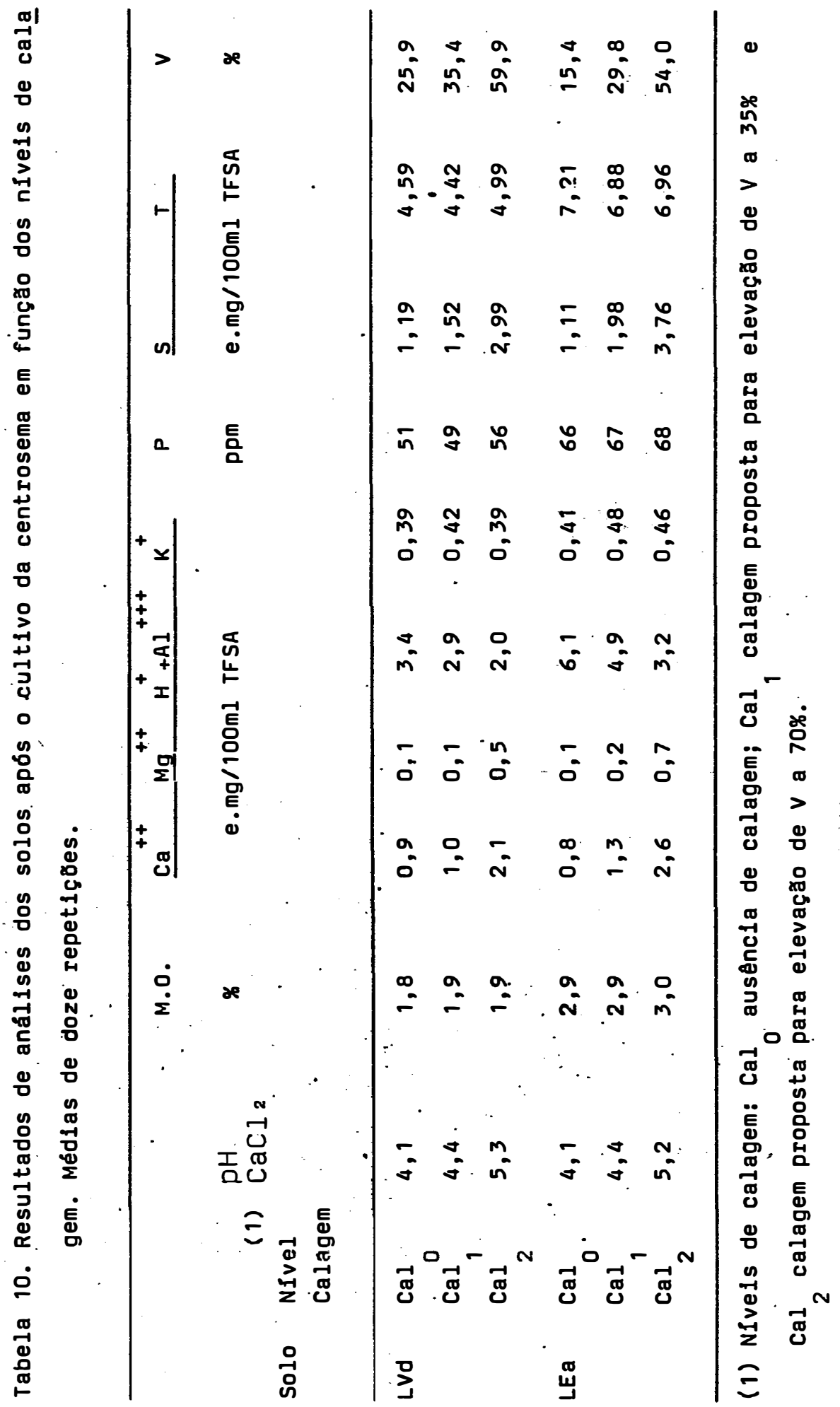


Tabela 11. Produção de matéria seca a $65^{\circ} \mathrm{C}$ da parte aérea, do capim colo nião. Médias entre os tratamentos de níveis de fósforo e cala gem.

\begin{tabular}{cccccccc}
\hline \multirow{2}{*}{ Calagem } & $\begin{array}{c}\text { Fósforo } \\
\text { ppm }\end{array}$ & \multicolumn{5}{c}{ Matéria Seca $(\mathrm{g} /$ vaso) } & \multirow{2}{*}{ Total } \\
\cline { 3 - 6 } Sem & 20 & 4,49 & 7,68 & 8,25 & 4,81 & 25,23 \\
& 100 & 8,68 & 10,99 & 11,03 & 10,82 & 41,52 \\
& 200 & 8,30 & 13,20 & 12,58 & 11,28 & 45,36 \\
& $\bar{x}$ & 7,16 & 10,62 & 10,62 & 8,97 & 37,37 \\
& 20 & 3,95 & 8,84 & 9,43 & 6,06 & 28,28 \\
\multirow{2}{*}{ Com } & 100 & 9,63 & 14,59 & 12,06 & 13,21 & 49,49 \\
& 200 & 10,55 & 14,73 & 13,30 & 14,82 & 53,40 \\
& $\bar{x}$ & 8,04 & 12,72 & 11,60 & 11,36 & 43,72 \\
\hline
\end{tabular}


Tabela 12. Significâncias do teste $F$ para as produções de ma téria seca do capim colonião em função dos fatores fósforo, micronutrientes, calagem, interações e desdobramentos das interações significativas(1).

Fontes de Variação

Matēria seca

10 corte 20 corte 30 corte 40 corte Total

Fösforo (P

Micronutrientes (M)

Ealagem (C)

$P \times M$

$P \times C$

$M \times C$

$P \times M \times C$

$C$ dentro $P_{20}$

C dentro 100

C dentro 200

$P$ dentro sem $C$

$\mathrm{P}$ dentro com $\mathrm{C}$

$P$ dentro sem $M$

$P$ dentro com $M$

$M$ dentro $P_{20}$

$M$ dentro $P_{100}$

M dentro 200

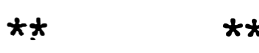

ns

**

ns

*

ns

ns

ns

*

**

**

$* *$

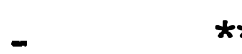

$-\quad * *$

-. ns

- ns

- ns
**

ns

*

**

$\star *$

$\star \star$

ns
**

ns

ns

ns

ns

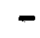

$\star \star$

*

**

ns

*

ns

ns

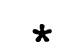

**

**

**

**
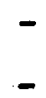

-

(1) ns = não significativo; * significativo $(P \leq 0,05)$ e ** significati vo $(P<-0,01)$

- interação não significativa 
Tabela 13. Quantidades totais de nitrogēnio acumuladas (mg/vaso), em quatro cortes, na parte aérea do capim colonião em função dos nī veis de fósforo na presença ou ausēncia da calagem.

\begin{tabular}{cccccc} 
& & \multicolumn{5}{c}{ Nitrogēnio Total } \\
\cline { 3 - 6 } Calagem & Fósforo $(\mathrm{ppm})$ & $1^{\circ} \mathrm{C}$ & $2^{\circ} \mathrm{O} C$ & $3^{\circ} \mathrm{C}$ & $4^{\circ} \mathrm{C}$ \\
\hline \multirow{2}{*}{ Sem } & 20 & 125,2 & 182,9 & 155,5 & 105,5 \\
& 100 & 181,5 & 208,2 & 179,0 & 141,6 \\
& 200 & 188,9 & 195,1 & 195,8 & 142,3 \\
& $\overline{\mathrm{X}}$ & 165,2 & 195,4 & 176,8 & 129,8 \\
& 20 & 109,4 & 183,6 & 163,4 & 122,0 \\
& 100 & 184,8 & 189,1 & 190,0 & 154,9 \\
& 200 & 212,9 & 214,9 & 212,9 & 163,3 \\
& $\bar{X}$ & 169,00 & 195,9 & 188,8 & 146,7 \\
\hline
\end{tabular}


Tabela 14. Significâncias pelo teste $F$ para os desdobramentos das interações significativas de micronutrientes $x$ adubação fosfatada $e$ anālise de regressão para os efeitos do fósforo dentro da apli cação de micronutrientes $(1)$.

Fontes de Variação

Nitrogênio Total

10 corte 20 corte

Fósforo sem micro

Reg. linear

**

$\star \star$

Reg. quadr.

$\star \star$

ns

Fósforo com micro

$\star \star$

$\star \star$

Reg. linear

**

$\star \star$

Reg. quadr.

$\star \star$

nis

(1) * e ** significāncias aos nīveis de $5 \%$ e $1 \%$ de probabilidade, respec tivamente. ns = não significativo. 


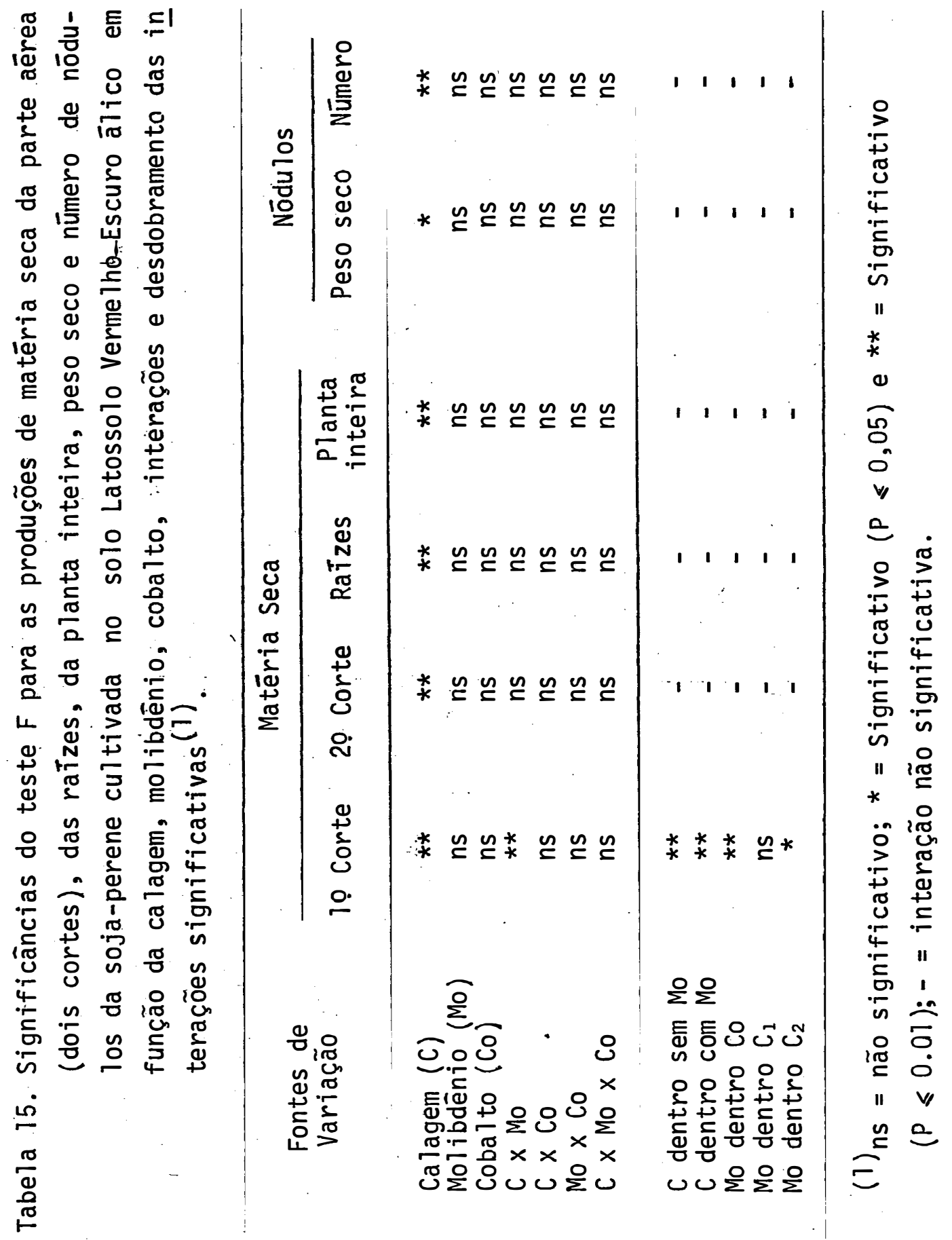


Tabela 16. Produção de matéria seca (g/vaso) da parte aérea, das raizes, da planta inteira e nodulação (mg/vaso e nūmero) da soja perene cultivada no solo La tossolo Vermelho-Escuro álico em função dos nīveis de calagem. Significāncia do teste $F^{1}$ para os componentes linear e quadrático. Médias de 12 dados.

Tratamentos $\frac{\text { Matéria seca }-g / \text { vaso }}{10 \text { corte } 20 \text { corte Raĩzes Planta inteira Peso seco Número(a) }}$

$\begin{array}{lllllll}\text { Sem calagem } & 5,59 & 1,69 & 1,32 & 3,01 & 17 & 9\end{array}$

$\begin{array}{lllllll}\text { Calagem } 1 & 6,69 & 3,23 & 1,63 & 4,86 & 113 & 53\end{array}$

$\begin{array}{llllll}\text { Calagem } 2 & 7,92 & 6,04 & 3,69 & 7,73 & 209\end{array}$

Reg. linear ** ** ** **. $\quad$ * $*$

Reg. quadr. ns ns ns ns ns ns

(a) Para anālise estatistica os dados foram transformados; $\sqrt{x+1}$

(1) * e ** = significāncias aos nīveis de $5 \%$ e $1 \%$ de probabi lidade, respectivamente.

ns = não significativo. 


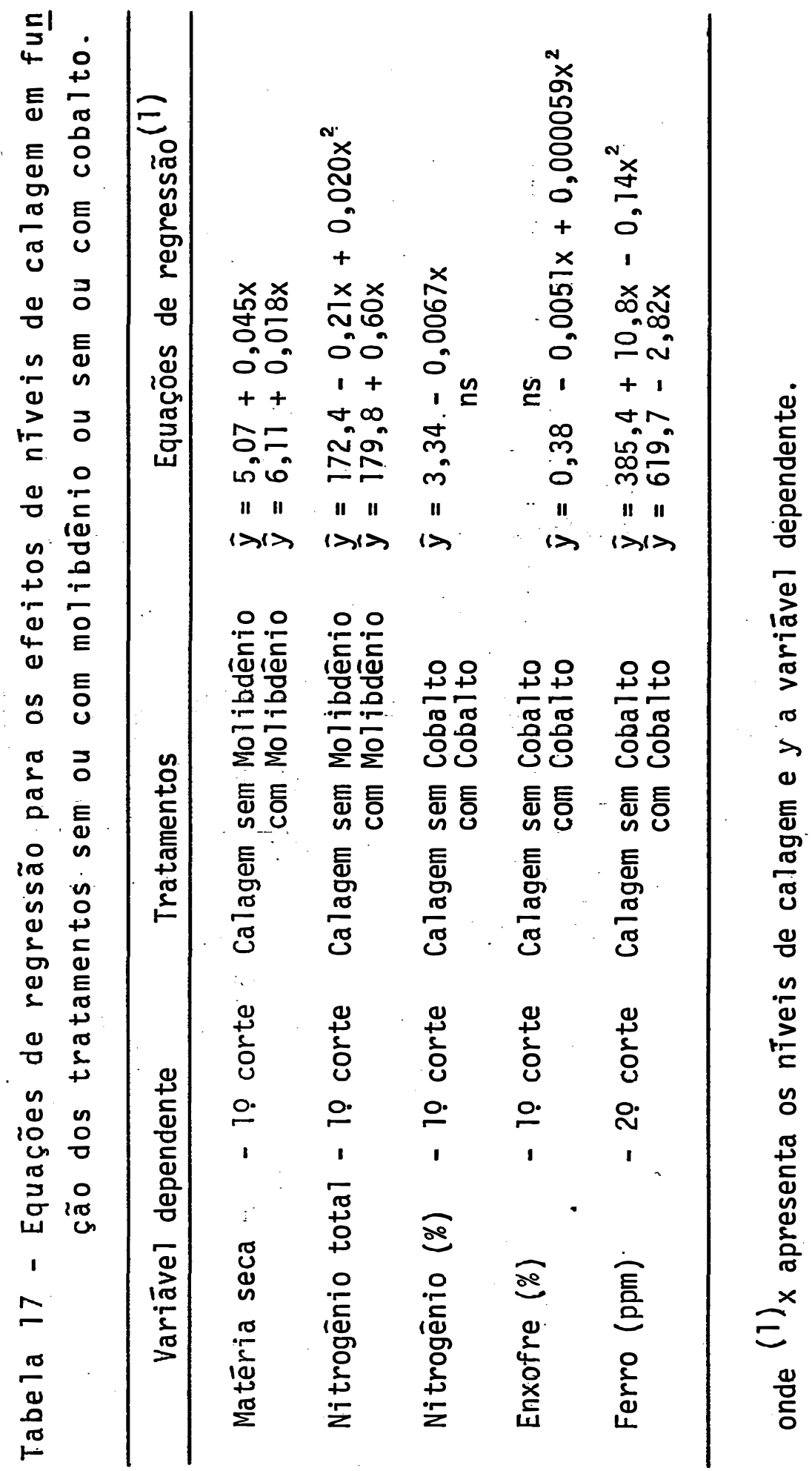


Tabela 18. Produção de matérịa seca (g/vaso) da isoja-perene cultivada no solo LEa, em função dos nĩveis de calagem e mediante a aplicação ou não de molibdēnio.

T̄ratamentos Matéria seca - lo corte

Médias seguidas pela mesma letra na linha não diferem entre si pelo teste de Tukey a $5 \%$. 
Tabela 19. Produção de matéria seca (g/vaso) da parte aérea, das raĩzes e da planta inteira e nodulação (peso seco, $\mathrm{mg} /$ vaso e número de nōdulos) da soja-perene cultivada no solo Latossolo Vermelho- $\underline{A}$ marelo distrōfico em função dos nīveis de calagem. Significância do teste $F^{1}$ para os componentes linear e quadrático. Médias de 12 dados (1).

Tratamentos

$\frac{\text { Matéria seca }}{10 \text { corte } 20 \text { corte Raîzes Planta inteira }} \frac{\text { Nodulação }}{\text { Peso seco Nūmerō }}$

Sem calagem

5,03

1,30

1,43

3,00

23,8

33,9

Calagem 1

7,11

$2,46 \quad 2,12$

4,58

$89,3 \quad 113,4$

Calagem 2

9,42

$6,52 \quad 3,62$

10,14

281,9

379,7

Reg. linear

**

**

**

**

**

**

Reg. quadr.

ns

**

*

$\star \star$

(1)* e ** significāncias aos nīveis de $5 \%$ e $1 \%$ de probabilidade, respecti vamente.

(a) Para anālise estatística os dàdos foram transformados em $\sqrt{x+1}$. 
Tabela 20. Significāncias do teste $F$ para as produções de matēria seca da parte aérea (dois cortes.), das raīzes, da planta inteira e pa ra nodulação (número e peso seco dos nōdulos da soja perene cultivada no solo Latossolo Vermelho-Amarelo ālico em função da calagem, molibdēnio, cobalto, interações e desdobramento das interações significativas (i).

Fontes de

Matēria seca

Nodulação

Variação

10 corte 20 corte Raĩzes Planta inteira Peso seco Número

\begin{tabular}{|c|c|c|c|c|c|c|}
\hline Calagem (C) ... & $* *$ & $\star \star$ & ** & ** & ** & ** \\
\hline Molibdēnio (Mo) & ns & ns & ns & ns & ns & ns \\
\hline Cobalto (Co) & ns & ns & ns & ns & ns & ns \\
\hline$C \times M o$ & ns & ns & ns & ns & ns & ns \\
\hline$C \times C_{0}$ & ns & ns & ns & ns & ns & ns \\
\hline Mo $\times$ Co & ns & ns & ns & ns & ns & ns \\
\hline$C \times$ Mo $\times$ Co & ns & ns & ns & ns & ns & ns \\
\hline
\end{tabular}

(1) ns = não significativo, * significativo $(P \leq 0,05)$ e ** ' significativo: $(P \leq 0,01)$, - interação não significativa. 
Tabela 21. Equações de regressão para os efeitos dos nĩveis de calagem sobre diversas variāveis em. soja perene cuiltivada no solo Latossolo Vermelho Amarelo distrōfico.

\begin{tabular}{|c|c|c|c|c|c|c|}
\hline & V́ariāvel & dependente & & & & Equaçōes de Regressão(l) \\
\hline & Peso seco & & Parte aērea & & $\begin{array}{l}19 \text { corte } \\
20 \text { corte }\end{array}$ & $\begin{array}{l}y=4,99+0,063 x \\
y=1,30-0,0086 x+0,0012 x^{2}\end{array}$ \\
\hline & . & & Raĩzes & $\therefore$ & & $y=1,42-0,0085 x+0,00032 x^{2}$ \\
\hline & & - & Planta inteir & & & $y=2,99-0,0017 x+0,0016 x^{2}$ \\
\hline & Nitrogênio total & & · & & $\begin{array}{l}10 \text { corte } \\
20 \text { corte }\end{array}$ & $\begin{array}{l}y=133,6-0,17 x+0,0123 x^{2} \\
y=34,9-0,68 x+0,043 x^{2}\end{array}$ \\
\hline & Nodulaçāo & • & $\begin{array}{l}\text { Peso seco } \\
\text { Nưmero. }\end{array}$ & & . & $\begin{array}{l}y=23,8-0,053 x+0,052 x^{2} \\
y=5,82+0,081 x+0,0016 x^{2}\end{array}$ \\
\hline$\because$ & Nitrogênio (\%) & ' & & . & $\begin{array}{l}19 \text { corte } \\
29 \text { corte }\end{array}$ & $\begin{array}{l}y=2,72-0,029 x+0,00025 x^{2} \\
y=2,67-0,011 x+0,00023 x^{2}\end{array}$ \\
\hline & Fōsforo (\%) & & & & 19 corte & $y=0,26-0,00036 x$ \\
\hline & Potāssio (\%) & & & & $\begin{array}{l}19 \text { corte } \\
29 \text { corte }\end{array}$ & $\begin{array}{l}y=2,59-0,010 x \\
y=3,51-0,013 x\end{array}$ \\
\hline & Cálcio (\%) & & & & $\begin{array}{l}19 \text { corte } \\
29 \text { corte }\end{array}$ & $\begin{array}{l}y=1,41+0,0034 x \\
y=1,92+0,59 x-0,00016 x^{2}\end{array}$ \\
\hline & Magnēsio (\%) & & $\therefore$ & & $\begin{array}{l}10 \text { corte } \\
29 \text { corte }\end{array}$ & $\begin{array}{l}y=0,36+0,0031 x+0,000044 x^{2} \\
y=0,41+0,0080 x-0,000083 x^{2}\end{array}$ \\
\hline & Enxofre (\%) & & $\ddots$ & $\cdot$ & 19 corte & $y=0,54-0,0028 x$ \\
\hline & Boro (ppm) & & & & 29. corte & $y=123,0-0,31 x$ \\
\hline & Cobre $(\mathrm{ppm})$ & & & & 19 corte & $y=4,25+0,044 x-0,00099 x^{2}$ \\
\hline & Ferro (ppm) & & & & 19 corte & $y=144,1+0,97 x-0,019 x^{2}$ \\
\hline & Manganēs (ppm) & & $\cdot \cdot$ & & $\begin{array}{l}19 \text { corte } \\
29 \text { corte }\end{array}$ & $\begin{array}{l}y=676,6-13,08 x+0,065 x^{2} \\
y=844,4-10,46 x\end{array}$ \\
\hline & Zinco (ppm) & & - & & $\begin{array}{l}19 \text { corte } \\
29 \text { corte }\end{array}$ & $\begin{array}{l}y=857-0,15 x-0,0093 x^{2} \\
y=117,65-1,17 x\end{array}$ \\
\hline
\end{tabular}

(1) onde y representa a variável estudada e $0 \times 0$ nivel de calagem dentro dos limites . utilizados. 
Tabela 22. Produção de matēria seca (g/vaso) da parte aériea, das raizes e da planta inteira e peso seco dos nō dulos (mg/vaso) da centrosema cultivada no solo La tossolo Vermelho-Escuro ālico. Significāncias do teste $F^{l}$ para os componentes linear e quadrático.

Tratamentos

Matēria seca

Nōdutos $(a)$

10 corte 20 corte Raĩzes Planta inteira Peso seco

Sem calagem

11,0

7,66

3,49

10,9

1008

Calagem 1

11,0

8,71

3,46

12,1

1284

Calagem 2

11,5

11,57

4,16

15,7

1350

Reg. linear

ns

Reg. quadr.

ns

**

*
*

ns
**

* $\star \star$

ns

$(1) *$ e $* *=$ signíficancias aos nî̉veis de $5 \%$ e $1 \%$ respectiva mente.

ns = não significativo.

(a) Para a análise estatística os dados foram transformados em $\sqrt{x+1}$ 
Tabela 23. Significāncias do teste $F^{(1)}$ para as produções de matēria seca da parte aérea, das raízes, da planta inteira e peso seco dos nódulos da centrosema cultivada no solo Latossolo VermelhoEscuro àlico.

\begin{tabular}{|c|c|c|c|c|c|c|}
\hline \multirow{2}{*}{$\begin{array}{l}\text { Fontes de } \\
\text { Variação }\end{array}$} & \multicolumn{4}{|c|}{ Matéria Seca } & \multicolumn{2}{|c|}{ Nōdulos } \\
\hline & 10 Corte & 20 Corte & Raĩzes & $\begin{array}{l}\text { Planta } \\
\text { inteira }\end{array}$ & Peso & Seco \\
\hline Calagem (C) & ns & $\star \star$ & * & $\star \star$ & & $\star \star$ \\
\hline Molibdénio (Mo) & ns & ns & $\star \star$ & ns & & ns \\
\hline Cobalto (Co) & ns & ns & * & ns & & $\star \star$ \\
\hline $\mathrm{C} \times \mathrm{Mo}$ & ns & ns & ns & ns & & ns \\
\hline$C \times C O$ & ns & ns & ns & ns & & ns \\
\hline Mo $\times$ Co & ns & ns & ns & ns & & ns \\
\hline$C \times$ Mo $\times$ Co & ns & ns & ns & ns & & ns \\
\hline C dentro sem Mo & - & - & $\star *$ & - & & - \\
\hline C dentro com Mo & - & - & ns & - & & - \\
\hline Mo dentro $\mathrm{Cal} 0$ & - & - & ns & - & & - \\
\hline Mo dentro $\mathrm{Ca}\}_{1}$ & - & - & ns & - & & - \\
\hline Mo dentro $\mathrm{CaI}_{2}$ & - & - & $\star \star \star$ & - & & - \\
\hline
\end{tabular}

(1) * e $* *=$ Significāncia aos níveis de $5 \%$ e $1 \%$, respectivamente; ns = não significativo; - = interação não significativa. 
Tabela 24. Equações de regressão para os efeitos dos niveis de calagem sobre as diversas variáveis em centrosema cultivada no solo Latossolo Vermelho-Escuro àlico.

\begin{tabular}{|c|c|c|}
\hline \multicolumn{2}{|c|}{ Variāvel dependeñte } & \multirow{2}{*}{ 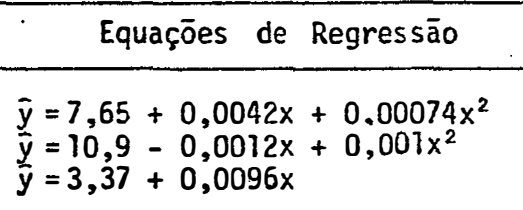 } \\
\hline Matēria Seca (g/vaso) & $\begin{array}{l}20 \text { corte } \\
\text { Planta inteira } \\
\text { Raizes }\end{array}$ & \\
\hline Nitrogēnio Total (mg/vaso) & $\begin{array}{l}19 \text { corte } \\
29 \text { corte }\end{array}$ & $\begin{array}{l}\bar{y}=216,0+0,93 x \\
\bar{y}=195,4-0,88 x+0,047 x^{2}\end{array}$ \\
\hline Nōdutos Peso Seco ( $g /$ vaso) & & $\bar{y}=1043,1+4,89 x$ \\
\hline Nitrogēṇio (\%) & $\begin{array}{l}19 \text { corte } \\
29 \text { corte }\end{array}$ & $\begin{array}{l}\bar{y}=1,98+0,0069 x \\
y=2,51-0,0061 x+0,00022 x^{2}\end{array}$ \\
\hline Cālcio (\%) & $\begin{array}{l}10 \text { corte } \\
20 \text { corte }\end{array}$ & $\begin{array}{l}\bar{y}=1,63+0,0034 x \\
y=0,93+0,0063 x-0,000066 x^{2}\end{array}$ \\
\hline Magnēsio (\%) & $\begin{array}{l}10 \text { corte } \\
29 \text { corte }\end{array}$ & $\begin{array}{l}\bar{y}=0,28+0,0019 x+0,000025 x^{2} \\
\bar{y}=0,18+0,0019 x\end{array}$ \\
\hline Enxofre (\%) & 29 corte & $\bar{y}=0,29+0,00077 x-0,000018 x^{2}$ \\
\hline Boro (ppm) & 18 corte & $\bar{y}=66,5+0,25 x$ \\
\hline Cobre (ppm) & 10 corte & $\bar{y}=14,4-0,027 x$ \\
\hline Manganēs (ppm) & $\begin{array}{l}19 \text { corte } \\
29 \text { corte }\end{array}$ & $\begin{array}{l}\bar{y}=690-6,83 x \\
\bar{y}=572-1,41 x-0,060 x^{2}\end{array}$ \\
\hline Zinco (ppm) & $\begin{array}{l}19 \text { corte } \\
20 \text { corte }\end{array}$ & $\begin{array}{l}\hat{y}=63,2-0,38 x \\
y=41,3+0,21 x-0,0037 x^{2}\end{array}$ \\
\hline
\end{tabular}

onde $y$ representa a variāvel estudada e $x \bar{e}$ o nîvel e calagem dentro dos limites utilizados. 
Tabela 25. Significāncias do teste $F^{1}$ para as produções de ma téria seca da parte aérea, das raizes e da planta inteira e peso seco dos nódulos da centrosema cultivada no solo Latossolo Vermelho-Amarelo distrófi co.

Fontes de variação $\frac{\text { Matēria seca }}{10 \text { corte } 20 \text { corte Raĩzes Planta inteira }} \frac{\text { Nódulos }}{\text { Peso seco }}$

Calagem $(C)$ ns $(\mathrm{C})$ ns $\quad$ *

Molibdēnio (Mo) ns ns ns ns ns

Cobalto (Co) ns ns ns ns ns

$\mathrm{C} \times \mathrm{MO}$ ns ns ns, ns, ns

$\begin{array}{llllll}C \times C O & n s & n s & n s & n s & \text { ns }\end{array}$

Mo $x$ Co ns ns ns ns ns

$\mathrm{C} \times \mathrm{Mo} \times \mathrm{CO}$ ns ns ns ns ns

(1) * e ** significāncias aos nīveis de $5 \%$ e $1 \%$, respectivamente. ns = não significativo. 
Tabela 26. Produção de matēria seca (g/vaso) da parte aérea das raĩzes,da planta inteira e peso seco dos nōdulos (mg/vaso) da centrosema cultivada no solo Latossolo Vermelho-Amarelo distrófico em função dos nīveis de calagem. Significâncias do teste $F^{(1)}$ pa ra os componentes linear e quadrātico. Médias de 12 dados.

\begin{tabular}{|c|c|c|c|c|c|}
\hline \multirow{2}{*}{ Tratamentos } & \multicolumn{4}{|c|}{ Matēria Seca } & \multirow{2}{*}{$\frac{\text { Nódulos }(a)}{\text { Peso Seco }}$} \\
\hline & 10 Corte & 20 Corte & Raizes & $\begin{array}{l}\text { Planta } \\
\text { inteira }\end{array}$ & \\
\hline Sem calagem & 9,16 & 5,94 & 2,96 & 8,92 & 1029,9 \\
\hline Calagem 1 & 9,45 & 7,66 & 3,36 & 11,01 & 1235,0 \\
\hline Calagem 2 & 9,43 & 10,92 & 3,46 & 14,40 & 1311,4 \\
\hline Reg. Tinear & ns & $\star \star$ & ns & ** & $\star \star$ \\
\hline Reg. quadrātica & ns & ns & ns & * & ns \\
\hline
\end{tabular}

(1)* e ** Significāncias aos nĩveis de $5 \%$ e $1 \%$, respectivamente e ns = não significativo.

(a) Para a anāilise estatística os dados foram transformados em $\sqrt{x+1}$. 
Tabela 27. Equação de regressão para os efeitos de níveis de calagem sobre as diversas variāveis em centrosema cultivada no solo La tossolo Vermelho-Amarelo.

$\begin{array}{ccc}\begin{array}{c}\text { Matéria seca } \\ \text { g/vaso }\end{array} \quad \text { Parte aérea - } 20 \text { corte } & \bar{y}=5,68+0,071 x \\ \bar{y}=8,71+0,078 x\end{array}$

Nitrogēnio total - 10 corte

$\mathrm{mg} /$ vaso

- 20 corte

$\underline{\hat{y}}=145,4-0,55 x+0,022 x^{2}$

$\bar{y}=132,4+3,25 x$

Nōdulos - Peso seco

$\bar{y}=1051,4+4,02 x$

$\mathrm{mg} /$ vaso

Nitrogēnio (\%) - 10 corte

$\bar{y}=1,59-0,0079 x+0,00025 x^{2}$

Cālcio $(\%)$

- 10 corte

$\bar{y}=1,35+0,0024 x+0,000080 x^{2}$

Magnēsio (\%)

- 10 corte

$\bar{y}=0,25+0,0010 x+0,000052 x^{2}$

Enxofre (\%) - 10 corte

$\bar{y}=0,28-0,0014 x+0,000035 x^{2}$

- 20 corte

$\bar{y}=0,36-0,0042 x+0,000034 x^{2}$

Boro (ppm)

- 10 corte

$\bar{y}=63,2-0,10 x+0,0066 x^{2}$

- 20 corte

$\bar{y}=62+0,30 x$

Cobre (ppm)

- 10 corte

$\bar{y}=5,3-0,02 x$

Ferro (ppm)

- 10 corte

$\bar{y}=130,5+0,72 x$

Manganēs (ppm) - 20 corte

$\bar{y}=622,0-6,22 x$

Zinco (ppm)

- 10 corte

$\bar{y}=54 ; 5-0,12 x-0,0037 x^{2}$
$\bar{y}=59,1-0,42 x$

onde y representa a variável dependente e $x$ o nîvel de calagem dentro dos limites estudados. 
Tabela 28. Significāncias do teste $F^{(1)}$ para as produções de matéria se ca da parte aérea, das raĩzes, da planta inteira e peso seco dos nōdulos da galactia cultivada no solo Latossolo VermelhoEscuro álico em função da calagem, do molibdênio, do cobalto e das interações e desdobramentos das interações significati vas.

\begin{tabular}{|c|c|c|c|c|c|c|}
\hline \multirow{2}{*}{$\begin{array}{l}\text { Fontes de } \\
\text { Variação }\end{array}$} & \multicolumn{5}{|c|}{ Matéria Seca } & \multirow{2}{*}{$\frac{\text { Nódulos }}{\text { Peso Sec }}$} \\
\hline & 10 Corte & 20 & Corte & Raízes & $\begin{array}{l}\text { Planta } \\
\text { inteira }\end{array}$ & \\
\hline Calagem (C) & ** & & ** & * & ** & $\star \star$ \\
\hline Molibdēnio (Mo) & $\star \star$ & & ns & ns & ns & ns \\
\hline Cobalto (Co) & ns & & ns & ns & ns & ns \\
\hline$C \times$ Mo & ns & & ns & ns & ns & ns \\
\hline$C \times$ Co & $\star \star$ & & ns & ns & ns & ns \\
\hline Mo $\times$ Co & ns & & ns & ns & ns & ns \\
\hline$C \times$ Mo $\times$ Co & ns & & ns & ns & ns & ns \\
\hline$C$ dentro sem Co & $\star *$ & & - & - & - & - \\
\hline C dentro com Co & ns & & - & - & - & - \\
\hline Co dentro $\mathrm{Ca}]_{0}$ & ** & & - & - & - & - \\
\hline Co dentro $\mathrm{Cal}_{1}$ & ns. & & - & - & - & - \\
\hline Co dentro $\mathrm{Cal}{ }_{2}$ & ns & & - & - & - & - \\
\hline
\end{tabular}

(1)* e ** = Significância aos nīveis de $5 \%$ e $1 \%$ de probabilidade, respectivamente; ns = não significativo; - = interação não significati va. 
Tabela 29. Produção de matēria seca (g/vaso) da parte aérea, das raizes, da planta inteira e peso seco dos nódu los (mg/vaso) da galactia cultivada no solo Latossolo Vermelho-Escuro ālico em função dos níveis de calagem. Significāncias do teste $F^{l}$ para os compo nentes linear e quadrātico. Médias de 12 dados.

\begin{tabular}{|c|c|c|c|c|c|}
\hline \multirow{2}{*}{ Tratamentos } & \multicolumn{4}{|c|}{ Matēria seca } & \multirow{2}{*}{$\frac{\text { Nödul os (à }}{\text { Peso seco }}$} \\
\hline & 10 corte & 20 corte & Raĩzes & Planta inteira & \\
\hline Sem calagem & 8,08 & 4,34 & 1,89 & 6,24 & 57 \\
\hline Calagem 1 & 9,47 & 4,91 & 1,57 & 6,48 & 119 \\
\hline Calagem 2 & 9,08 & 6,54 & 1,77 & 8,31 & 186 \\
\hline Reg. Tinear & ** & ** & ns & $\star \star$ & $\star \star$ \\
\hline Re. quadr. & $* *$ & ns & ** & $\star \star$ & ns \\
\hline
\end{tabular}

(1) * e ** =significâncias aos nĩveis de $5 \%$ e $1 \%$ de probabili dade, respectivamente.

$n s=$ não signficativo.

(a) Para a análise estatística os dados foram transformados em $\sqrt{x+1}$ 
Tabela 30. Equações de regressão para os efeitos de nĩveis de calagem sobre as diversas variāveis em galactia cultivada no solo Latossolo Ver melho-Escuro àlico.

Variāvel dependente

Equação de regressão

$\begin{array}{lll}\text { Matéria seca (g/vaso) - } & 10 \text { corte } & \bar{y}=8,09-0,065 x-0,00072 x^{2} \\ & \text { 20 corte } & \bar{y}=4,16+0,0316 x \\ & \text { Raízes } & \bar{y}=1,89-0,016 x+0,00021 x^{2} \\ & \text { Planta inteira } & \bar{y}=6,24-0,016 x+0,00065 x^{2}\end{array}$

Nōdutos (mg/vaso)

$\bar{y}=56,0+1,84 x$

Nitrogēnio total (mg/vaso) - 10 cortè

$\bar{y}=190,6-0,51 x+0,014 x^{2}$

20 corte $\bar{y}=52,6+0,96 x$

Nitrogēnio (\%) - 20 corte

$\bar{y}=1,22+0,020 x-0,00017 x^{2}$

Potássio (\%) - 10 corte

$\bar{y}=1,75-0,0044 x+0,000090 x^{2}$

Magnésio (\%) - 2 e corte

$\hat{y}=0,17+0,0014 x$

Enxofre $(\%)=20$ corte

$\bar{y}=0,48+0,00043 x-0,000034 x^{2}$

Cobre (ppm) - 10 corte

$\bar{y}=7,82-0,029 x$

Manganês (ppm) - 10 corte

$\bar{y}=585,0-11,9+0,064 x^{2}$

20 corte

$\bar{y}=564,5-6,58 x$

Zinco (ppm) - 20 corte

$\bar{y}=38,3-0,29 x+0,0027 x^{2}$

onde y representa a variável estudada e $x$ o nível de calagem dentro dos limites utilizados. 
Tabela 31. Produção de matéria seca (g/vaso) em função dos ní veis de calagem e mediante a aplicação ou não de cobalto da galactia cultivada no solo Latossolo Vermelho-Escuro ālico.

Tratamentos

Matéria seca-10 corte

\begin{tabular}{lll} 
& Sem Co & Com Co \\
Sem calagem & $7,49 \mathrm{~b}$ & $8,69 \mathrm{a}$ \\
Calagem 1 & $9,45 \mathrm{a}$ & $9,49 \mathrm{a}$ \\
Calagem 2 & $9,46 \mathrm{a}$ & $8,71 \mathrm{a}$ \\
\hline
\end{tabular}

Médias seguidas pela mesma letra, em cada linha, não diferem en tre si pelo teste de Tukey a $5 \%$. 
Tabela 32. Significâncias do teste $F^{(1)}$ para as produções de matéria seca da parte aérea, das raĩzes, da planta inteira e peso seco dos nōdulos da galactia cultivada no solo Latossolo Vermelho-Amare lo distrōfico em função da calagem, do molibdēnio, do cobalto e das interações entre esses fatores.

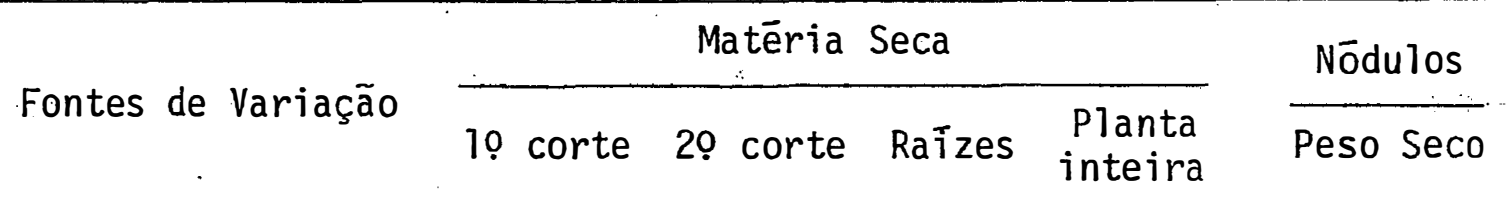

\begin{tabular}{|c|c|c|c|c|}
\hline Calagem (C) & ** & ** & ns & ** \\
\hline Molibdēnio (Mo) & ns & ** & ns & $\star \star$ \\
\hline Cobalto (Co) & ns & ns & ns & ns \\
\hline $\mathrm{C} \times \mathrm{Mo}$ & ns & ns & ns & ns \\
\hline$C \times$ Co & ns & ns & ns & ns \\
\hline Mo $\times$ Co & ns & ns & ns & ns \\
\hline$C \times$ Mo $\times$ Co & ns & ns & ns & ns \\
\hline
\end{tabular}

$(1)_{*} e^{* *}=$ Significāncias aos nīveis de $5 \%$ e $1 \%$ de probabilidade, respectivamente; $n s$ = não significativo. 
Tabela 33. Produção de matéria seca (g/vaso) da parte aérea, das raízes, e da planta inteira, em ambos os cortes, e nodulação (mg/vaso) da galactia cultivada no solo Latossolo Vermelho-Amarelo distrōfico em função dos nīveis de calagem. Significāncias do tes te $\mathrm{F}^{(1)}$ para os componentes linear e quadrätica. Médias de $\overline{12}$ dados.

\begin{tabular}{|c|c|c|c|c|c|}
\hline \multirow{2}{*}{ Tratamentos } & \multicolumn{4}{|c|}{ Matēria Seca } & \multirow{2}{*}{$\frac{\text { Nódulos }(a)}{\text { Peso Seco }}$} \\
\hline & 10 Corte & 20 Corte & Raĩzes & $\begin{array}{l}\text { Planta } \\
\text { inteira }\end{array}$ & \\
\hline Sem calagem & 7,20 & 5,02 & 2,00 & 7,05 & 202,4 \\
\hline Calagem 1 & 7,98 & 7,51 & 2,20 & 9,45 & 248,3 \\
\hline Calagem 2 & 7,75 & 9,03 & 2,26 & 11,29 & 294,1 \\
\hline Reg. linear & ns & $\star \star$ & ns & $\star \star$ & ** \\
\hline Reg. quadrātica & $\star \star$ & ns & ns & ns & ns \\
\hline
\end{tabular}

(1) e $^{\star \star}=$ Significâncias aos nīveis de $5 \%$ e $1 \%$ de probabilidade, respectivamente; ns = não significativo.

(a) Para a anālise estatística os dados foram transformados em $\sqrt{x+1}$. 
Tabela 34. Equações de regressão para os efeitos dos nỉveis de calagem sobre as diversas variāveis em galactia cultivada no solo Latossolo Vermelho-Amarelo distrófico.

Variāvel dependente Equações de Regressão
Matēria seca (g/vaso)
10 corte
20 corte
$\bar{y}=7,20+0,45 x-0,00065 x^{2}$
Planta inteira
$\bar{y}=5,18+0,057 \cdot x$
$\bar{y}=7 ; 14+0 ; 061 x$
Nōdulos (mg/vaso)
$\bar{y}=202,4+1,31 x$
Nitrogēnio total (mg/vaso)
10 corte
$\bar{y}=131,0-0,87 x+0,021 x^{2}$
$\bar{y}=104,4+3,28 x-0,021 x^{2}$
Nitrogēnio (\%)
10 corte
20 corte
$\bar{y}=1,83-0,023 x+0,00045 x^{2}$
$\bar{y}=2,04+0,021 x-0,00020 x^{2}$
Fösforo (\%)
10 corte
2 c corte
$\bar{y}=0,20-0,0003 x+0,000054 x^{2}$
$y=0,17-0,00039 x-0,0000010 x^{2}$
Potāssio (\%)
10 corte
$\bar{y}=1,87-0,014 x+0,00019 x^{2}$
20 corte
$y=2,24-0,0095 x+0,000058 x^{2}$
Cālcio (\%)
10 corte
2 . corte
$\bar{y}=1,68+0,010 x$
$\bar{y}=1,56+0,0026 x$
Magnésio (\%)
10 corte
20 corte
$\bar{y}=0,20+0,00099 x+0,000064 x^{2}$.
$\bar{y}=0,17-0,00065 x+0,000027 x^{2}$
Enxofre
10 corte
20 corte
$\bar{y}=0,36-0,0040 x-0,000041 x^{2}$
$\bar{y}=0,42-0,0028 x$
Boro (ppm)
10 corte
$\hat{y}=94,6-0,16 x+0,0071 x^{2}$
Cobre (ppm)
20 corte
$\bar{y}=6,23-0,033 x$
Manganēs (ppm)
10 corte
$\bar{y}=612,8-7,89 x$
$\bar{y}=486,0-4,50 x$
Zinco (ppm)
10 corte
20 corte
$\bar{y}=49,6-0,28 x-0,0022 x^{2}$
$\bar{y}=52,0-0,75 x+0,0040 x^{2}$

onde $\boldsymbol{y}$ representa a variāvel estudada e $\mathbf{x} 0$ nīvel de calagem dentro dos limites utilizados. 


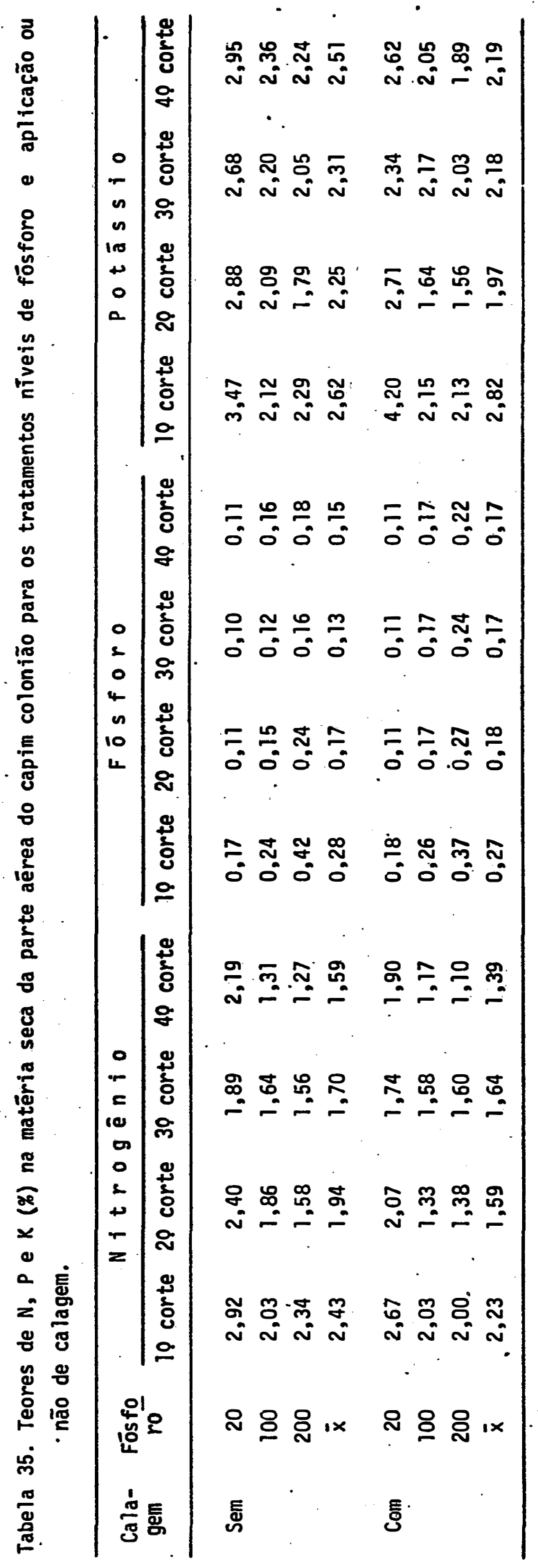




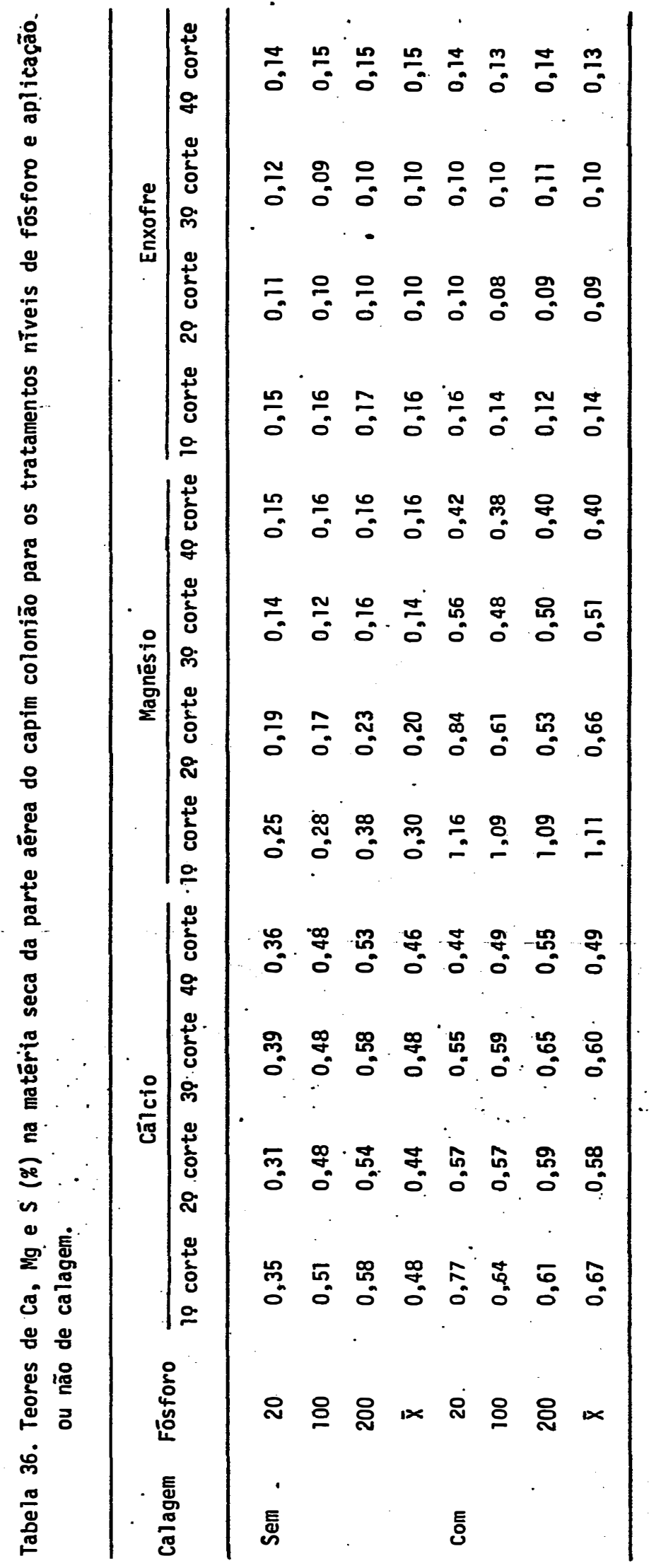




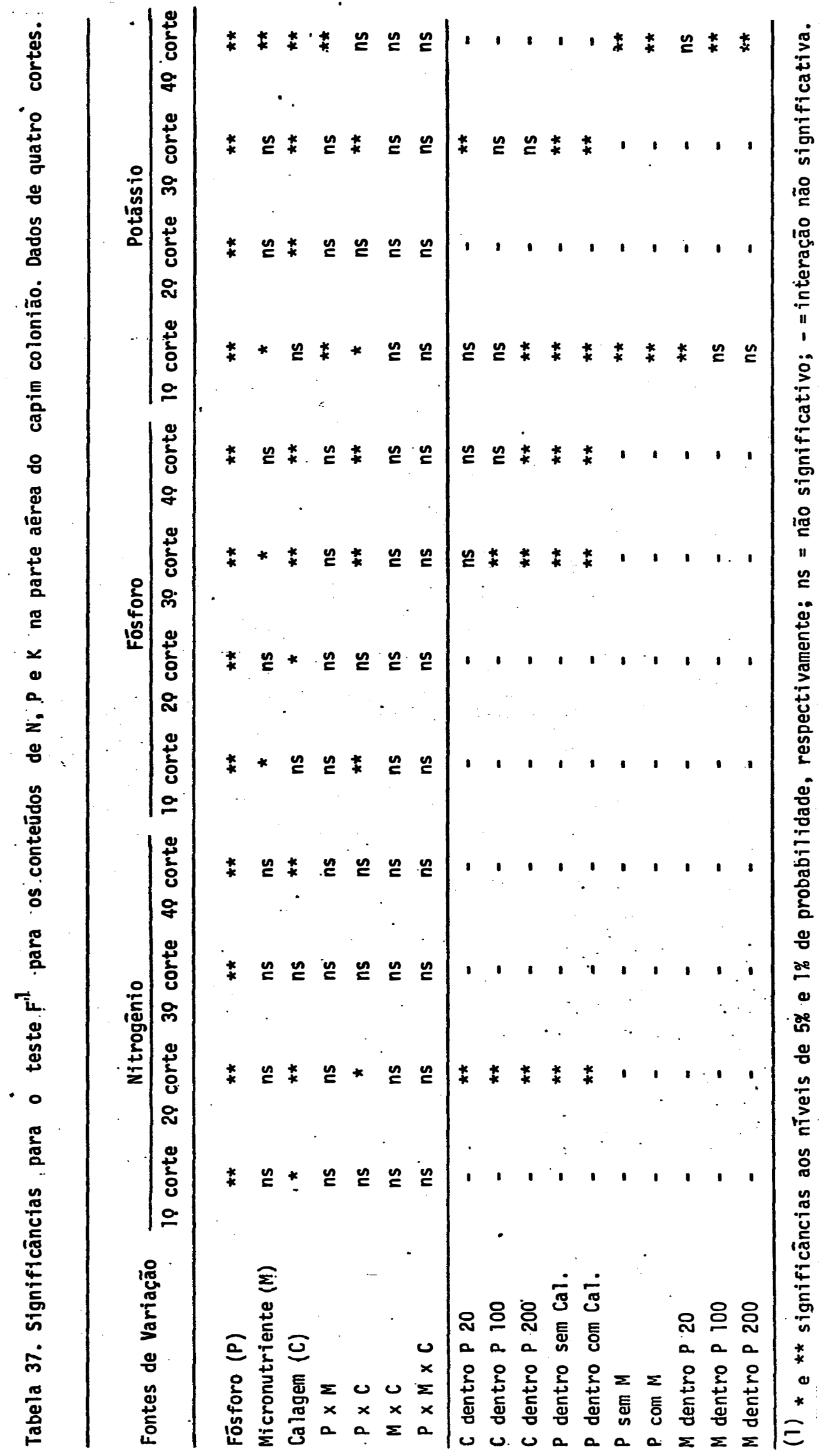


Tabela 38. Equações de regressão para os efeitos de nîveis de fōsforo $(x)$ sobre diversas variāveis, na presença $\left(\mathrm{Cal}_{2}\right)$ e na ausēncia de calagem ( $\left.\mathrm{Cal}_{0}\right)$.

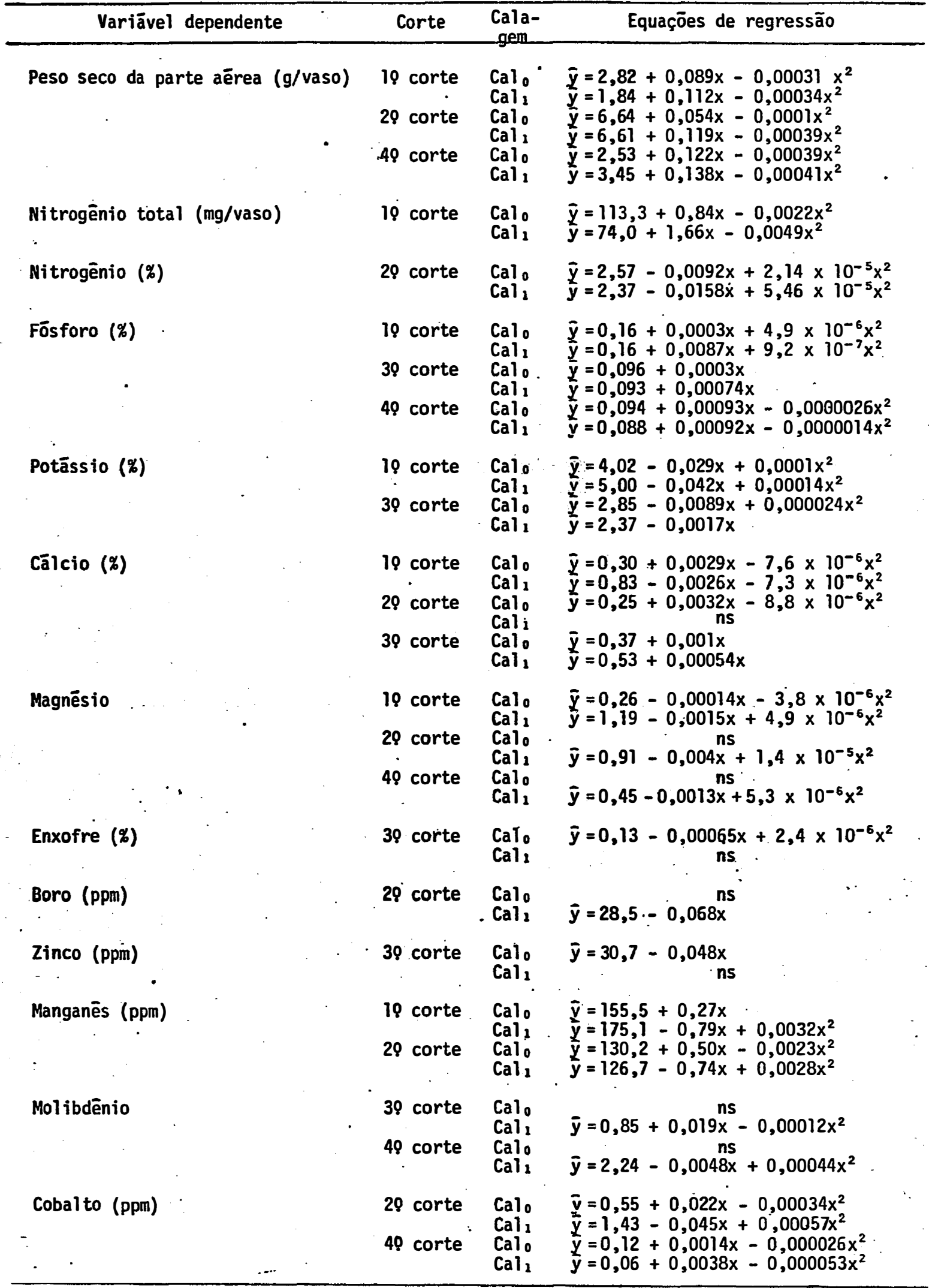


Tabela 39. Equações de regressão para os efeitos dos nĩveis de fósforo $(x)$ sobre diversas variāveis, na presença $\left(M_{1}\right)$ ou na ausência (Mo) de aplicação de micronutrientes.

Variāvel dependente Corte $\begin{gathered}\text { Micronu- } \\ \text { trientes }\end{gathered}$ Equações de regressão

\begin{tabular}{|c|c|c|c|}
\hline \multirow[t]{2}{*}{ Potāssio (\%) } & 10 corte & $\begin{array}{l}\text { Mo } \\
\text { M.1. }\end{array}$ & $\begin{array}{l}\bar{y}=4,02-0,029 x+0,0001 x^{2} \\
\bar{y}=5,00-0,042 x+0,00014 x^{2}\end{array}$ \\
\hline & 40 corte & $\begin{array}{l}M_{0} \\
M_{1}\end{array}$ & $\begin{array}{l}\bar{y}=2,76-0,0029 x \\
\bar{y}=3,09-0,015 x+0,000044 x^{2}\end{array}$ \\
\hline Enxofre $(\%)$ & 10 corte & $\begin{array}{l}\text { Mo } \\
M_{1}\end{array}$ & $\begin{array}{l}\bar{y}=0,15+0,00013 x \\
\bar{y}=0,16-0,00019 x\end{array}$ \\
\hline \multirow[t]{4}{*}{ Boro (ppm) } & 10 corte & $\begin{array}{l}M_{0} \\
M_{1}\end{array}$ & $\hat{y}=36,2-0,069 x$ \\
\hline & 20 corte & $\begin{array}{l}M 0 \\
M .1\end{array}$ & $\begin{array}{c}n s \\
\bar{y}=28,47 .-0,068 x\end{array}$ \\
\hline & 30 corte & $\begin{array}{l}M_{0} \\
M_{1}\end{array}$ & $\begin{array}{l}\bar{y}=8,07+0,17 x-0,00059 x^{2} \\
\bar{y}=31,99-0,050 x\end{array}$ \\
\hline & 40 corte & $\begin{array}{l}M 0 \\
M\end{array}$ & $\bar{y}=25,7-0,026 x$ \\
\hline \multirow[t]{2}{*}{ Cobre (ppm) } & 20 corte & $\begin{array}{l}M_{0} \\
M_{1}\end{array}$ & $\begin{array}{l}\bar{y}=6,30-0,021 x \\
\bar{y}=8,60-0,053 x+0,00019 x^{2}\end{array}$ \\
\hline & 40 corte & $\begin{array}{l}M_{0} \\
M_{1}\end{array}$ & $\begin{array}{l}\bar{y}=8,72-0,0099 x \\
\bar{y}=11,31-0,057 x+0,00020 x^{2}\end{array}$ \\
\hline \multirow[t]{2}{*}{ Zinco. (ppm) } & 10 corte & $M_{0}$ & $\begin{array}{l}\bar{y}=38,7-0,18 x+0,00071 x^{2} \\
\bar{y}=54,2-0,23 x+0,00075 x^{2}\end{array}$ \\
\hline & 20 corte & $\begin{array}{l}M_{\ddot{o}}^{\prime} \\
M_{1}\end{array}$ & $\bar{y}=44,8-0,054 x$ \\
\hline
\end{tabular}

onde $y$ é a variāvel dependente analisada e $x$ a dose de fósforo estudada. 


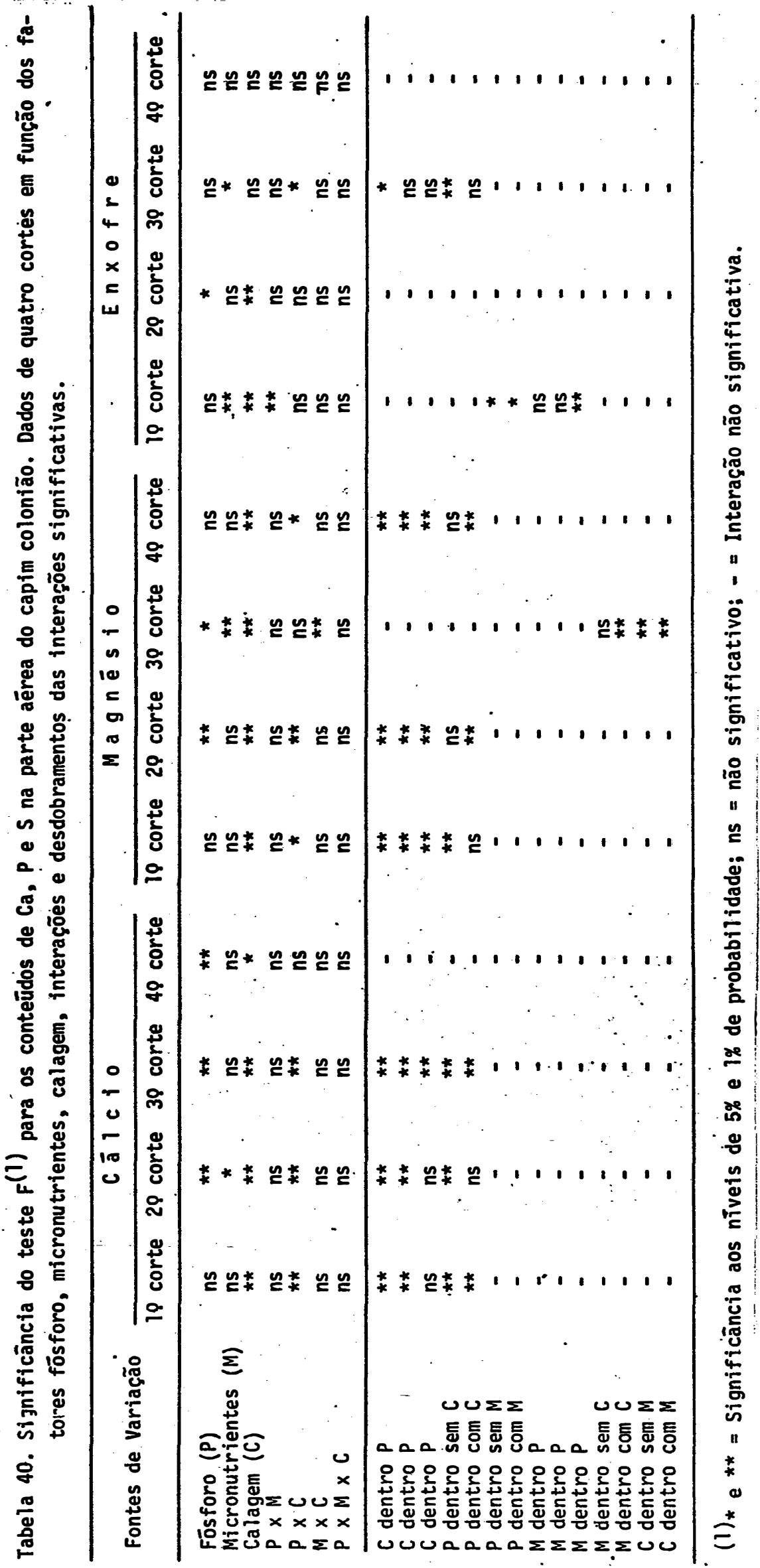


Tabela 41. Teores de Mg (\%), B, Zn e Mn, em ppm, para os tratamentos de calagem e micronutrientes $(1)$.

Calagem Micronutrientes $\frac{\text { Magnésio }}{3^{0}} \frac{\text { Boro }}{40 \text { corte }} \frac{\text { Zinco }}{40 \text { corte } 40 \text { corte } 20 \text { corte }}$

$\begin{array}{ccccccc}\text { Sem } & \text { Sem } & 0,14 a & 19 b & 33 b & 20 b & 162 a \\ & \text { Com } & 0,13 a & 25 a & 47 a & 28 a & 127 b \\ & \bar{x} & 0,14 & 22 & 40 & 24 & 144 \\ \text { Com } & 0,46 b & 19 b & 31 b & 18 b & 100 a \\ & \text { Sem } & 0,57 a & 21 a & 39 a & 29 a & 90 a \\ & & & & & & \\ & \text { Com } & 0,34 & 20 & 35 & 24 & 95\end{array}$

(1) Médias seguidas pelas mesmas letras dentro de cada grupo sem ou com mi cronutrientes não diferem entre si pelo teste de Tukey a $5 \%$. 


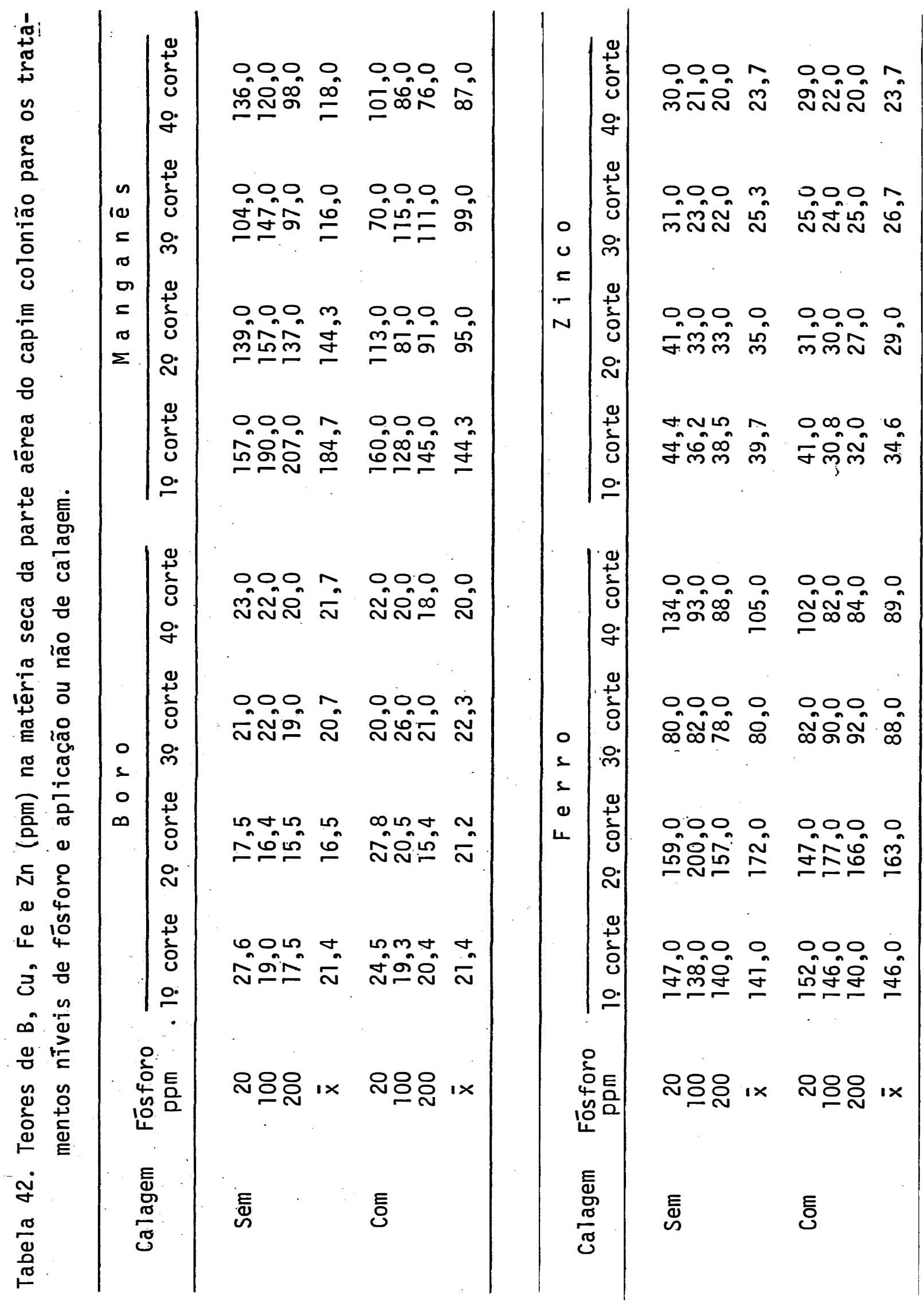




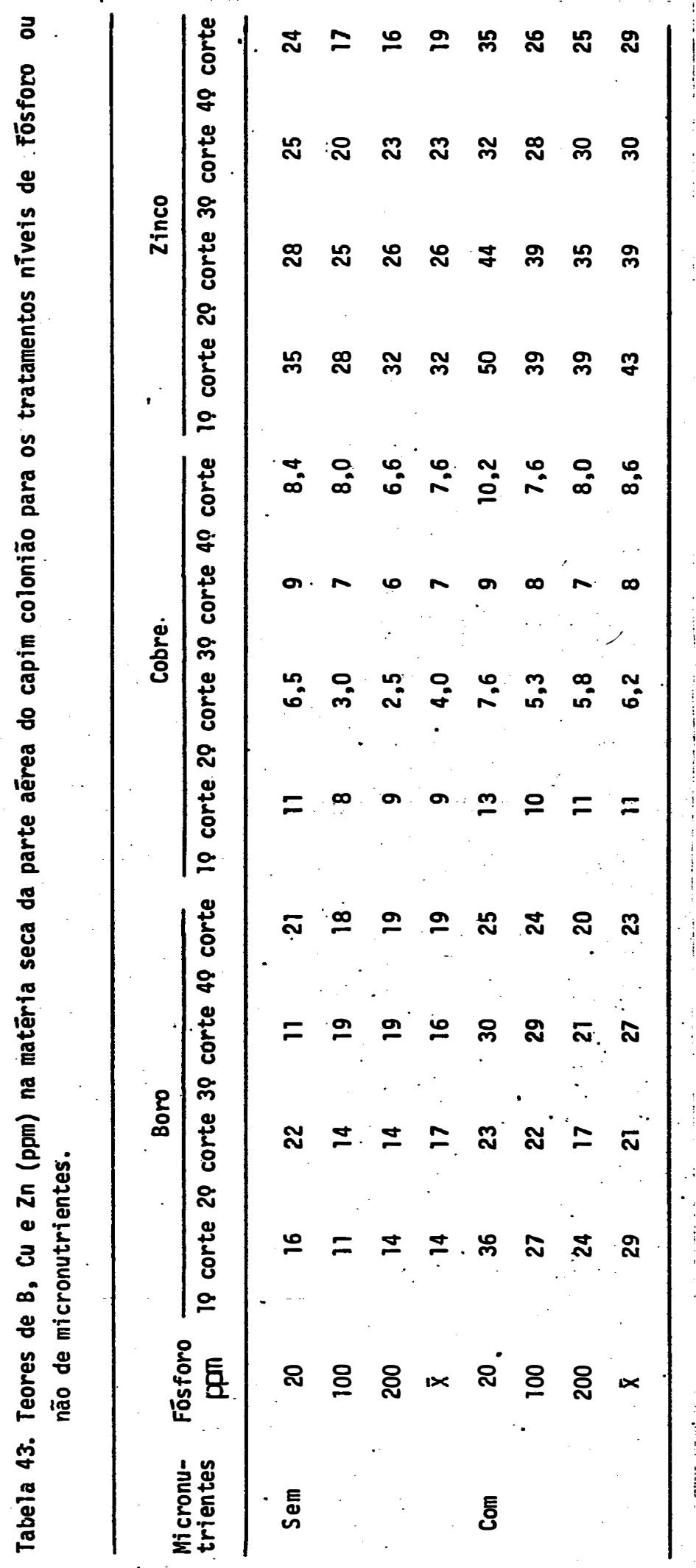




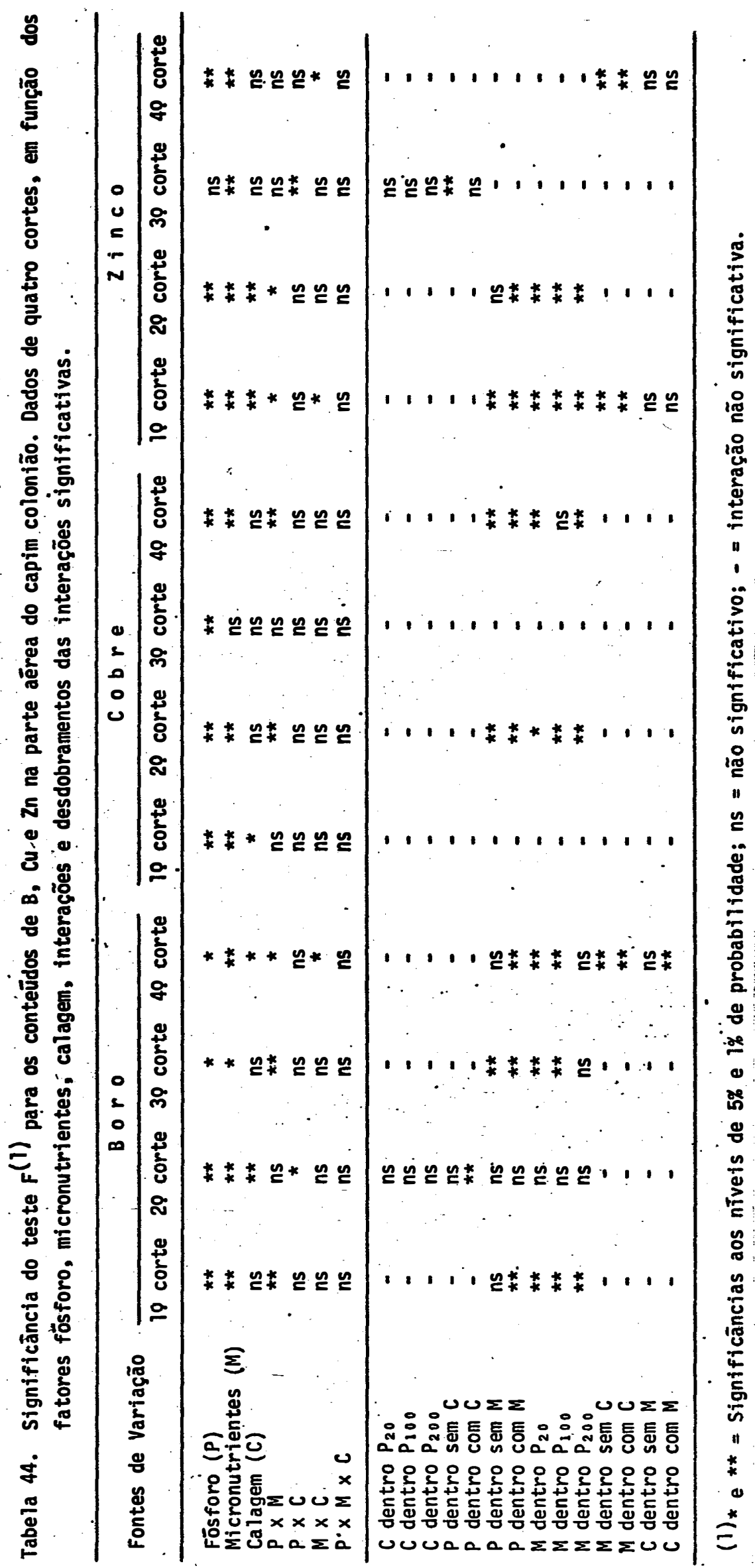




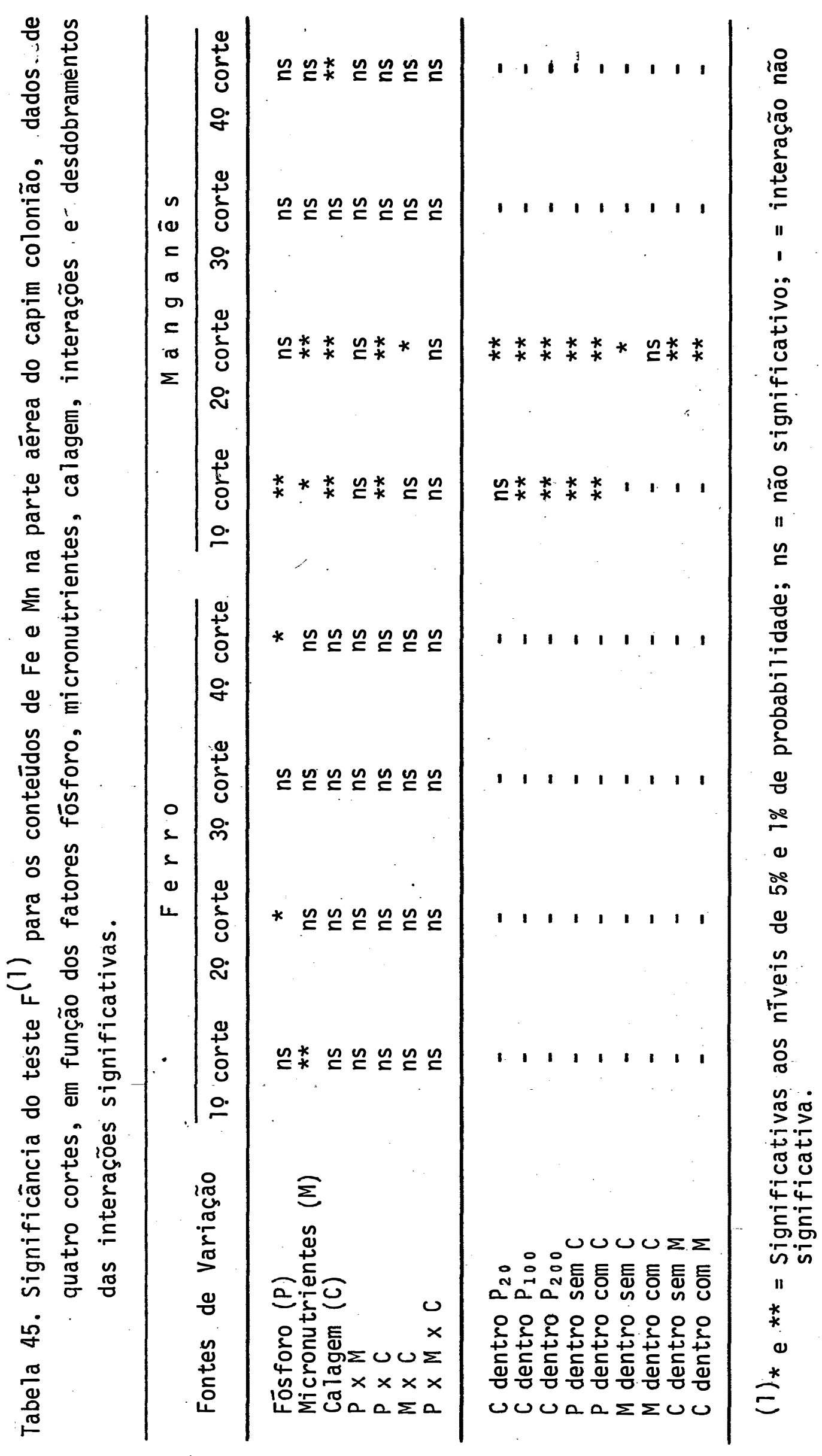




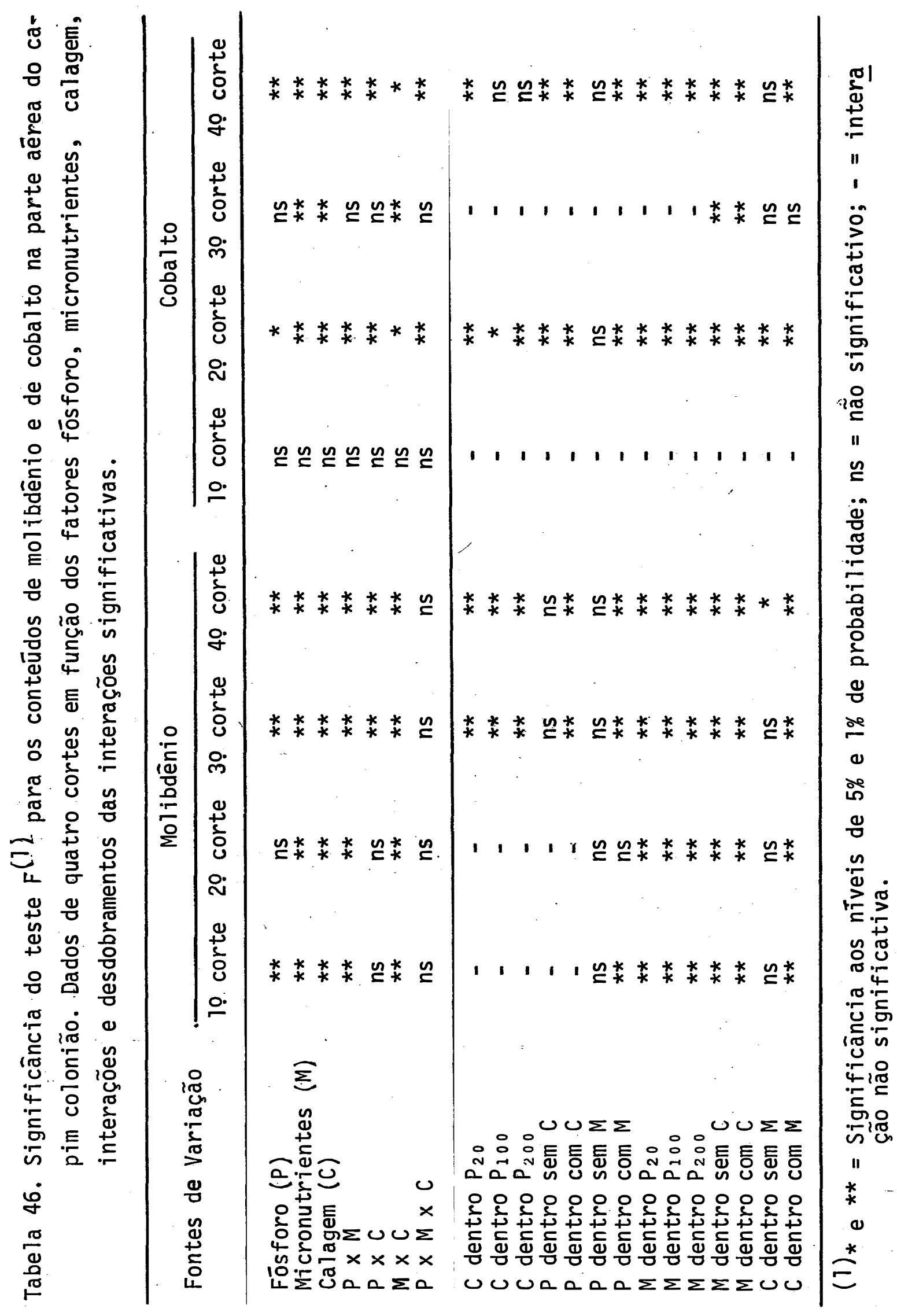




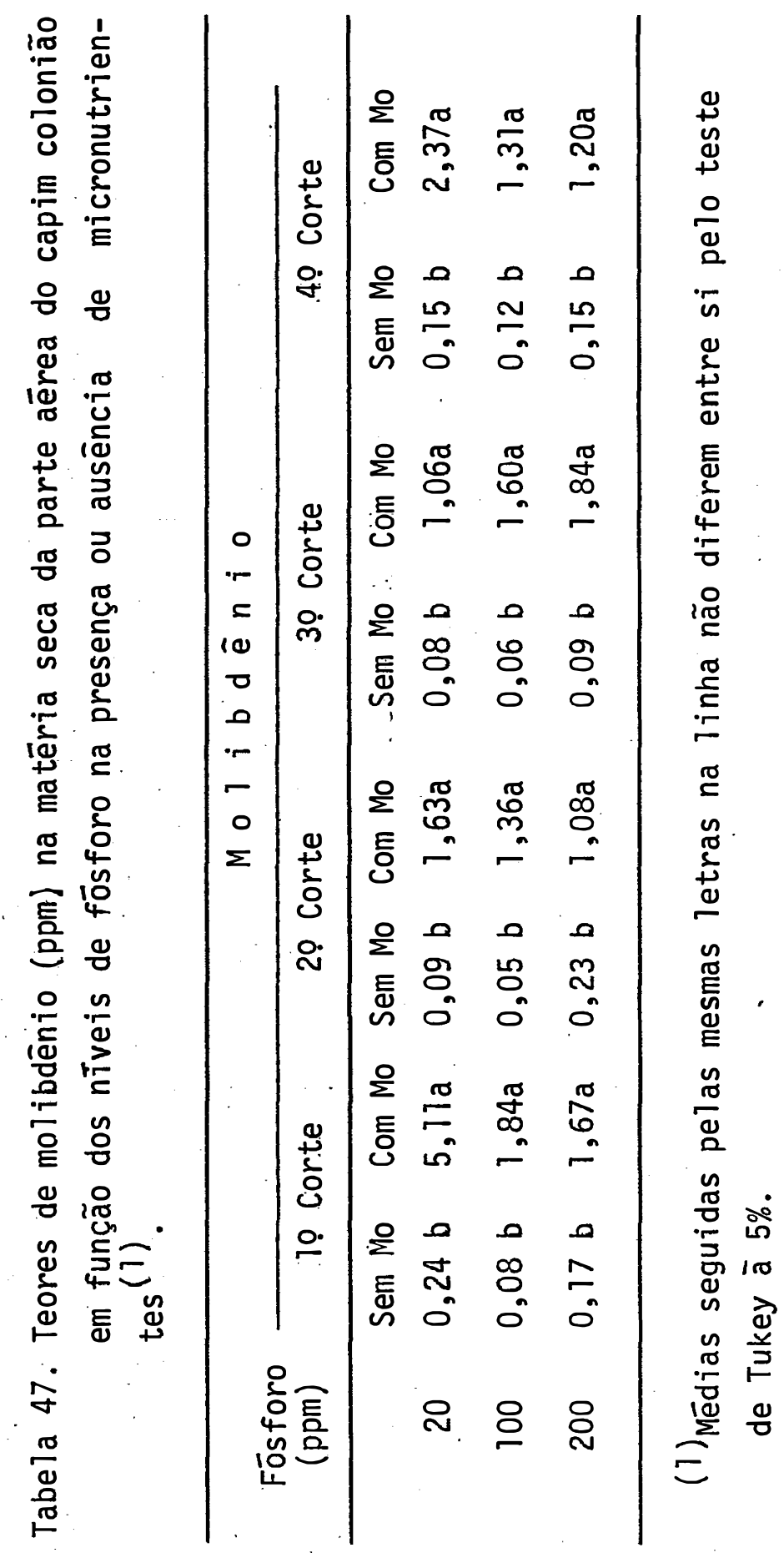




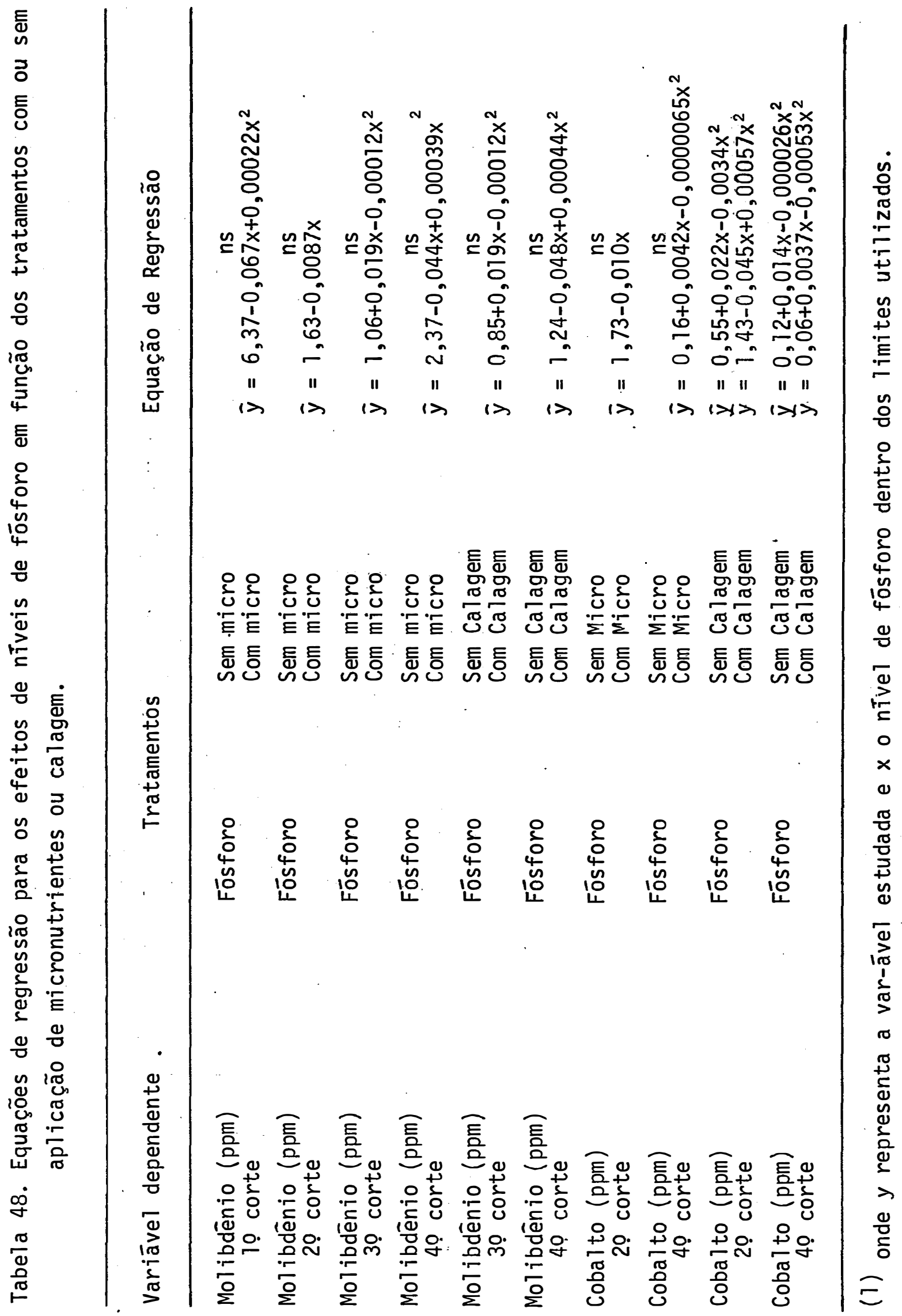


Tabela 49. Teores de molibdēnio e de cobalto (ppm) na matēria seca da par te aérea do capim colonião, em função da aplicação de nīveis de fósforo na presença ou na ausência de calagem.

\begin{tabular}{|c|c|c|c|c|c|}
\hline \multirow{2}{*}{$\begin{array}{l}\text { Fōsforo } \\
\text { (ppm) }\end{array}$} & \multirow{2}{*}{ Calagem } & \multicolumn{2}{|c|}{ Molibdēnio } & \multicolumn{2}{|c|}{ Cobal to } \\
\hline & & 30 corte & 40 corte & 20 corte & 40 corte \\
\hline \multirow[t]{2}{*}{20} & Sem & $0,28 \mathrm{~b}$ & $0,28 \mathrm{~b}$ & $0,54 \mathrm{~b}$ & 0,12 a \\
\hline & Com & $0,85 a$ & $1,24 a$ & $1,43 \mathrm{a}$ & $0,06 \mathrm{~b}$ \\
\hline \multirow[t]{2}{*}{100} & Sem & $0,29 \mathrm{~b}$ & $0,34 \mathrm{~b}$ & $0,90 \mathrm{a}$ & $0,14 a$ \\
\hline & Com & $1,38 \mathrm{a}$ & $1,10 a$ & $0,54 \mathrm{~b}$ & $0,13 \mathrm{a}$ \\
\hline \multirow[t]{2}{*}{20} & Sem & $0,34 \mathrm{~b}$ & $0,32 \mathrm{~b}$ & $0,43 \mathrm{~b}$ & $0,09 \mathrm{a}$ \\
\hline & Com & $1,60 \mathrm{a}$ & 1,02 a & $1,05 \mathrm{a}$ & $0,07 a$ \\
\hline
\end{tabular}

Médias seguidas pelas mesmas letras não diferem entre si pelo teste de Tu key a $5 \%$. 
Tabela 50. Teores de molibdénio (ppm) na matéria seca da parte aérea do capim colonião, em função da aplicação de nîveis de fósforo e de micronutrientes.

Fósforo Micronutrientes (ppm)

Molibdēnio

10 corte 20 corte 30 corte 40 corte

\begin{tabular}{llllllll}
\hline \multirow{2}{*}{20} & Sem & $0,24 \mathrm{~b}$ & $0,09 \mathrm{~b}$ & $0,08 \mathrm{~b}$ & $0,15 \mathrm{~b}$ \\
& Com & $5,11 \mathrm{a}$ & $1,63 \mathrm{a}$ & $1,06 \mathrm{a}$ & $2,37 \mathrm{a}$ \\
\multirow{2}{*}{100} & Sem & $0,08 \mathrm{~b}$ & $0,05 \mathrm{~b}$ & $0,06 \mathrm{~b}$ & $0,12 \mathrm{~b}$ \\
& Com & $1,84 \mathrm{a}$ & $1,36 \mathrm{a}$ & $1,60 \mathrm{a}$ & $1,31 \mathrm{a}$ \\
\multirow{2}{*}{200} & Sem & $0,17 \mathrm{~b}$ & $0,23 \mathrm{~b}$ & $0,09 \mathrm{~b}$ & $0,15 \mathrm{~b}$ \\
& Com & $1,67 \mathrm{a}$ & $1,08 \mathrm{a}$ & $1,84 \mathrm{a}$ & $1,20 \mathrm{a}$ \\
& & & & &
\end{tabular}

Médias seguidas pelas mesmas letras não diferem entre si pelo teste de Tu key a $5 \%$. 


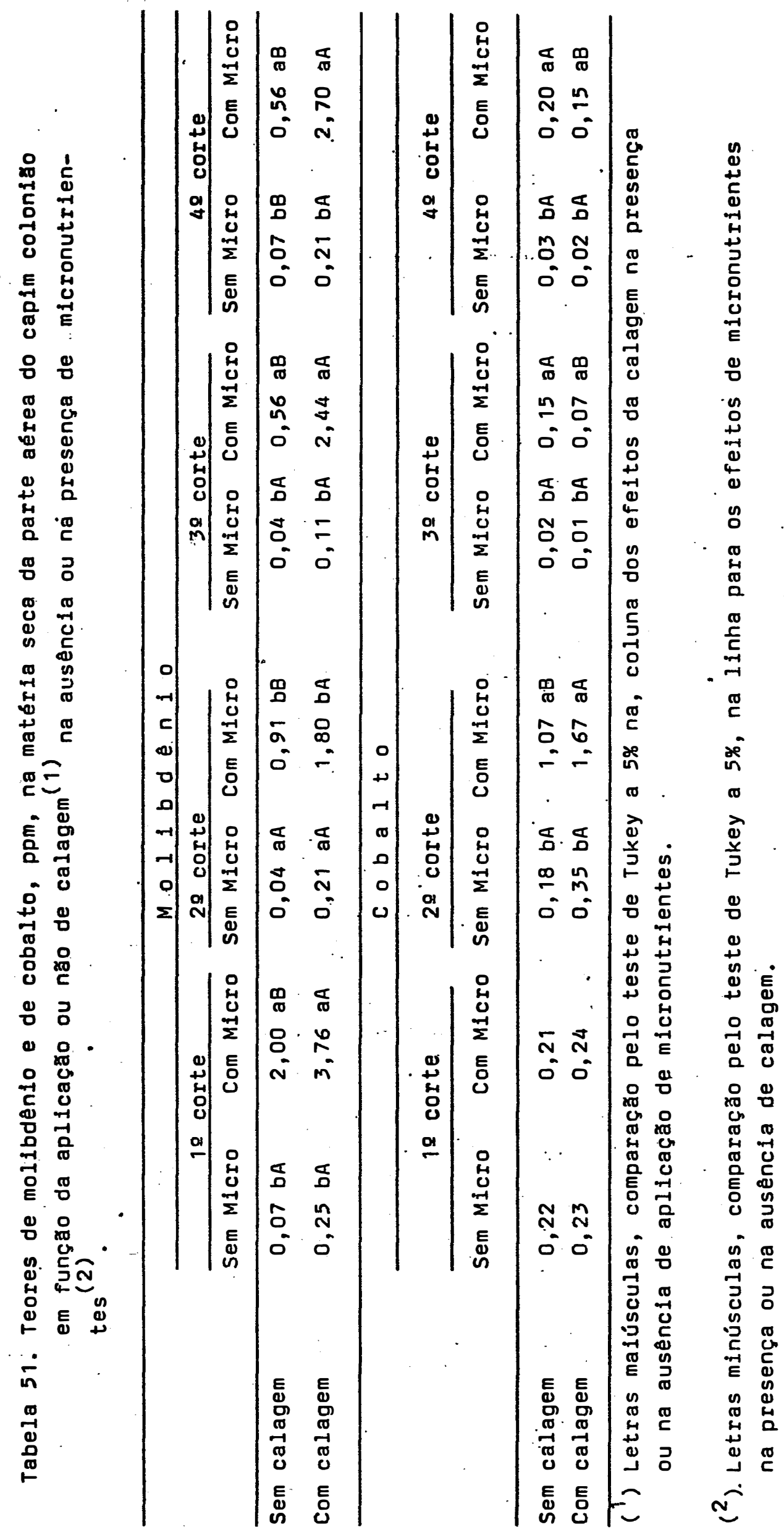




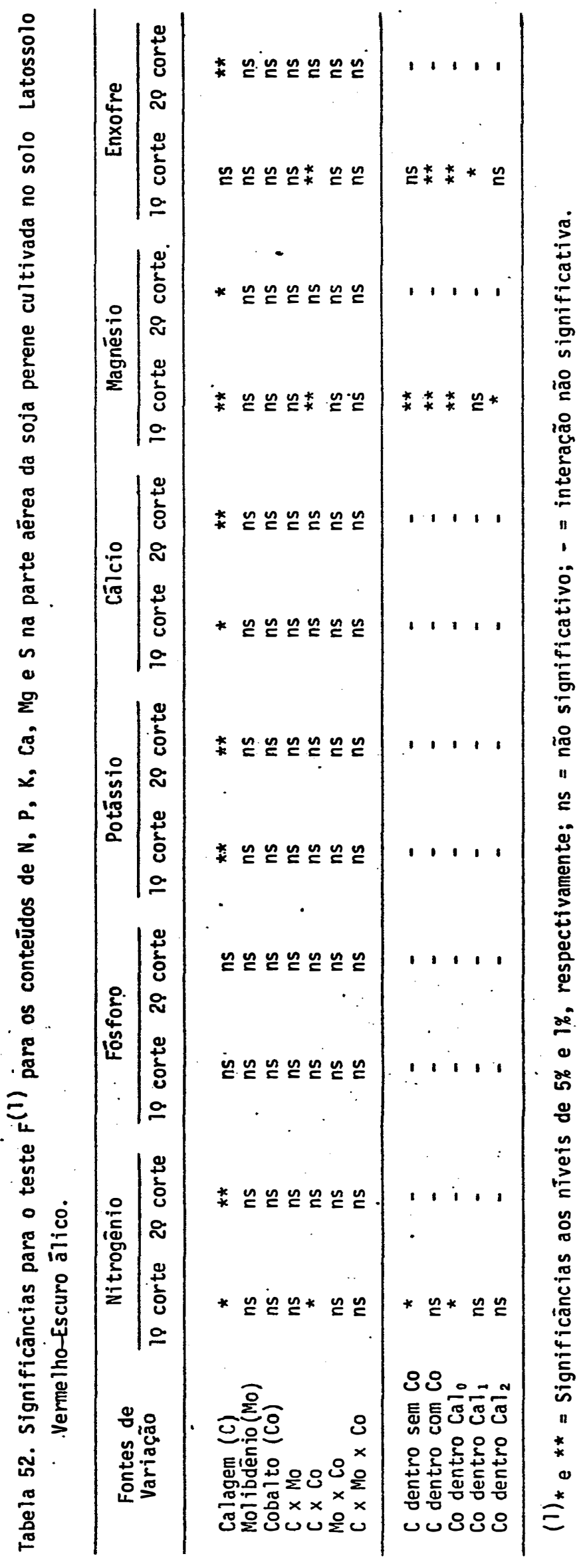




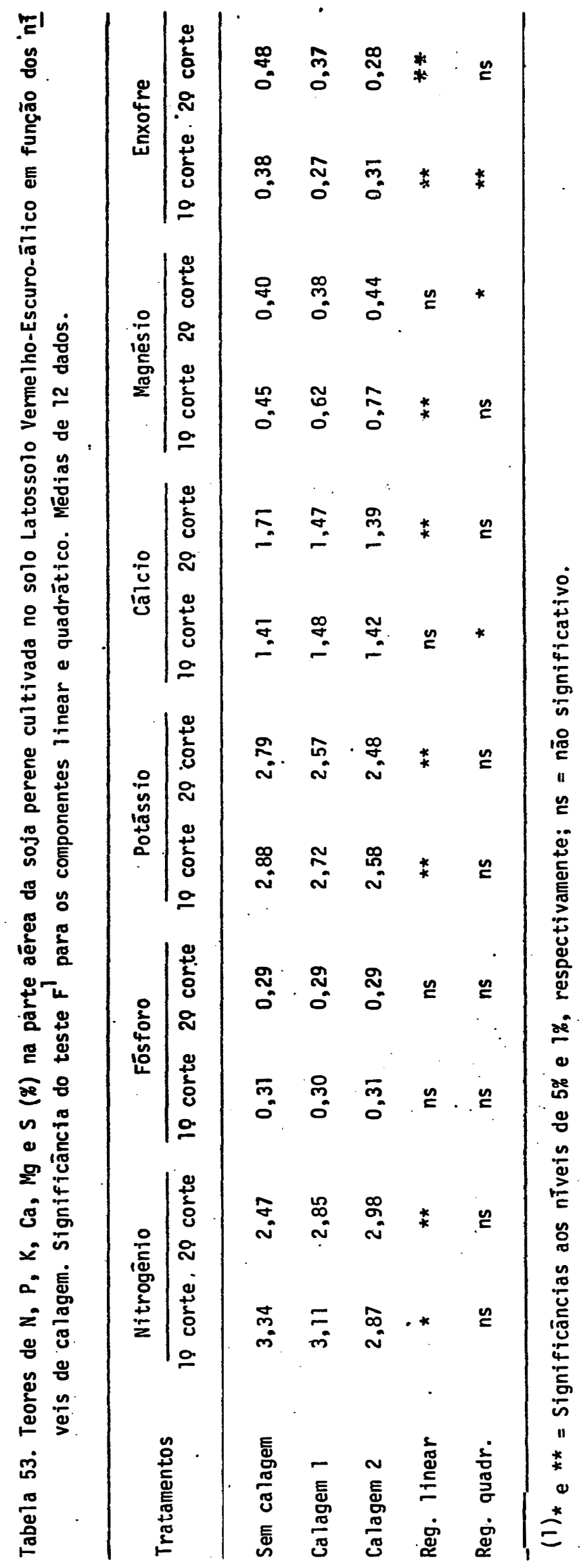


Tabela 54. Equações de regressão para os efeitos dos nĩveis de calagem sobre as diversas variāveis em soja perene cultivada no solo Latossolo Vermelho-Escuro.

Variāvel dependente

Equação de regressão

Matēria seca

(g/vaso)

Nitrogēnio Total

(mg/vaso)

Nodul ação - Nūmero

Nitrogēnio (\%)

Potássio (\%)

Cālcio (\%)

Magnēsio (\%)

Enxofre (\%)

Boro (ppm)

Cobre (ppm)

Manganês (ppm)

Zinco (ppm)
20 corte Planta :Inteira

20 corte

$$
\bar{y}=35,5+1,96 x
$$$$
\bar{y}=3,15+0,105 x
$$

20 corte

$\bar{y}=2,51+0,0074 x$

10 corte

$\bar{y}=2,87-0,0043 x$

20 corte

$\bar{y}=2,77-0,0044 x$

10 corte

$\bar{y}=1,41+0,0039 x-0,000053 x^{2}$
$\bar{y}=1,68-0,0045 x$

20 corte

10 corte

20 corte

$\bar{y}=0,46+0,0045 x$

$\bar{y}=0,39-0,0018 x+0,000035 x^{2}$

20 corte

$\bar{y}=0,48-0,00029 x$

20 corte

$\bar{y}=114,3-0,22 x$

10 corte

$\bar{y}=10,1-0,019 x$

10 corte

$\bar{y}$
$\frac{y}{y}=550-10,1 x+0,051 x^{2}$

20 corte

10 corte

20 corte $\bar{y}=50,4-0,28 x$

$y=57,2+0,15 x-0,0047 x^{2}$

Onde y representa a variāvel dependente e $x$ o nível de calagem dentro dos limites estudados. 
Tabela 55. Teores de $\mathrm{N}, \mathrm{S}(\%)$ e $\mathrm{Fe}(\mathrm{ppm})$ em função dos nĩveis de calagem e mediante a aplicação ou não de cobalto em soja perene cultivada no solo LEa.

\begin{tabular}{|c|c|c|c|c|c|c|}
\hline \multirow{2}{*}{ Tratamentos } & \multirow{2}{*}{\multicolumn{2}{|c|}{$\frac{\text { Nitrogēnio }}{10 \text { corte }}$}} & \multicolumn{2}{|c|}{ Enxofre } & \multicolumn{2}{|c|}{ Ferro } \\
\hline & & & 10 & orte & 20 & orte \\
\hline Sem Calagem & $\begin{array}{l}\text { Sem Co } \\
3,41 a\end{array}$ & $\begin{array}{l}\text { Com Co } \\
2,89 \text { b }\end{array}$ & $\begin{array}{l}\text { Sem Co } \\
0,29 \text { b }\end{array}$ & $\begin{array}{l}\text { Com Co } \\
0,38 a\end{array}$ & $\begin{array}{l}\text { Sem Co } \\
385 \text { b }\end{array}$ & $\begin{array}{c}\text { Com Co } \\
652 a\end{array}$ \\
\hline Calagem 1 & $2,98 a$ & $3,15 a$ & $0,31 a$ & $0,29 a$ & $597 a$ & $455 a$ \\
\hline Calagem 2 & $2,94 a$ & $3,13 a$ & $0,31 \mathrm{a}$ & $0,31 a$ & $477 a$ & $455 a$ \\
\hline
\end{tabular}

Médias seguidas pelas mesmas letras comparadas na linha não diferem en tre si pelo teste de Tukey a $5 \%$. 


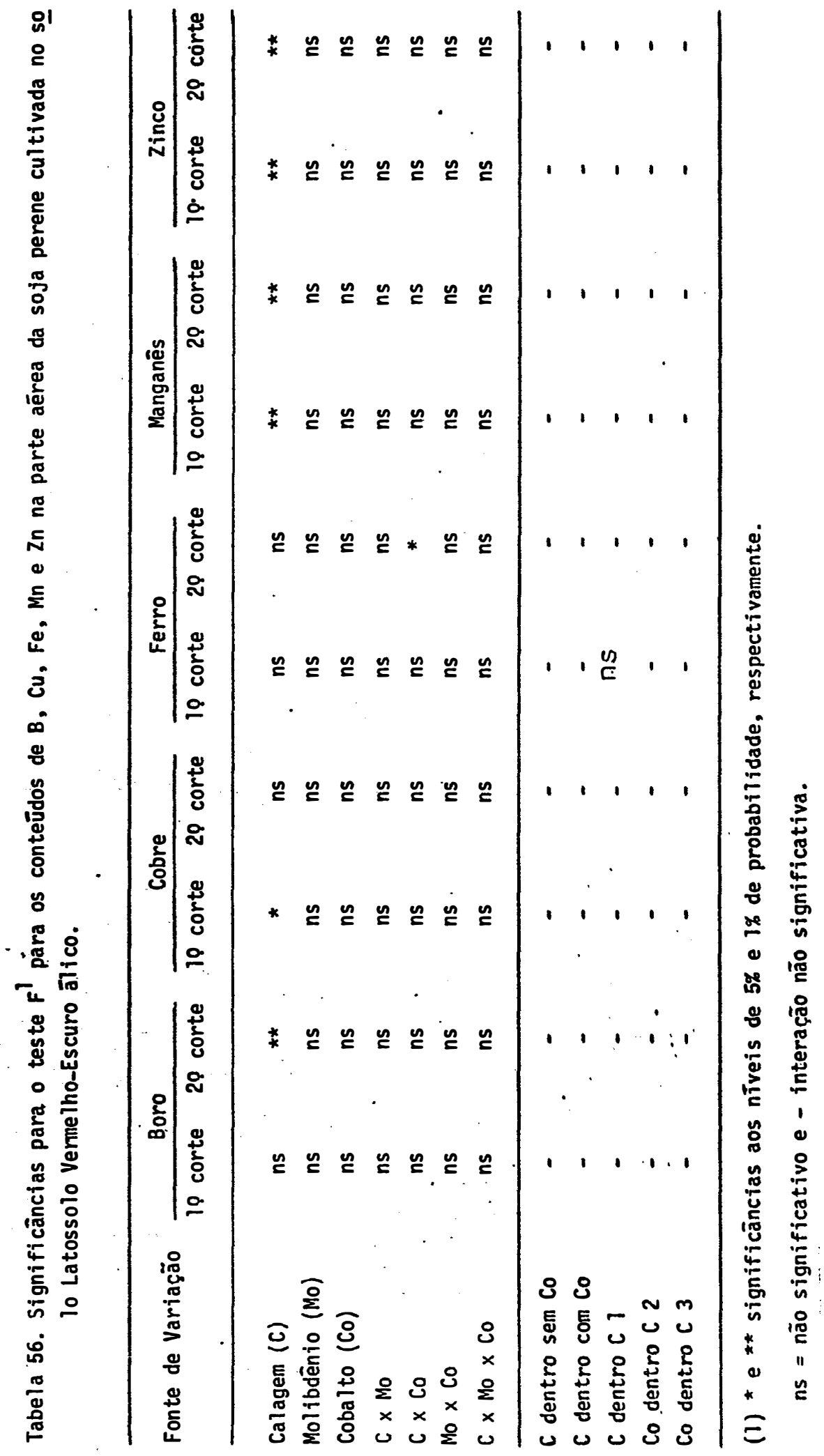




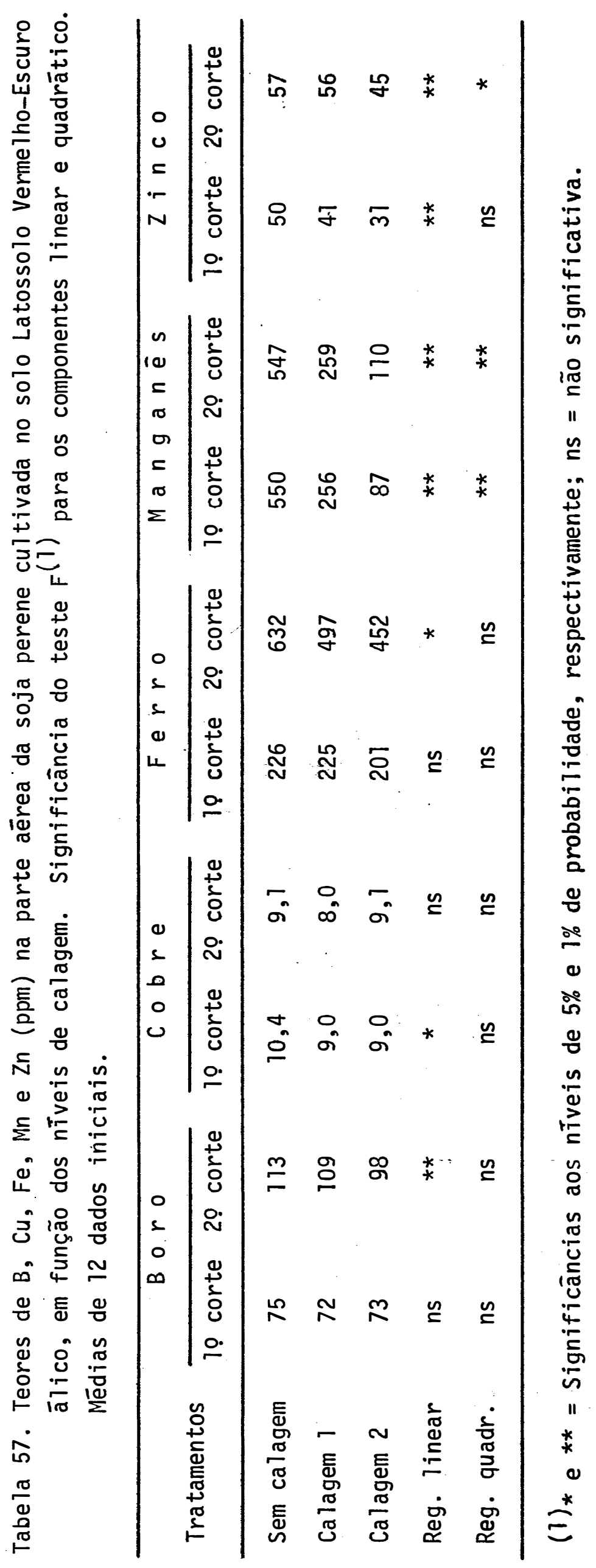




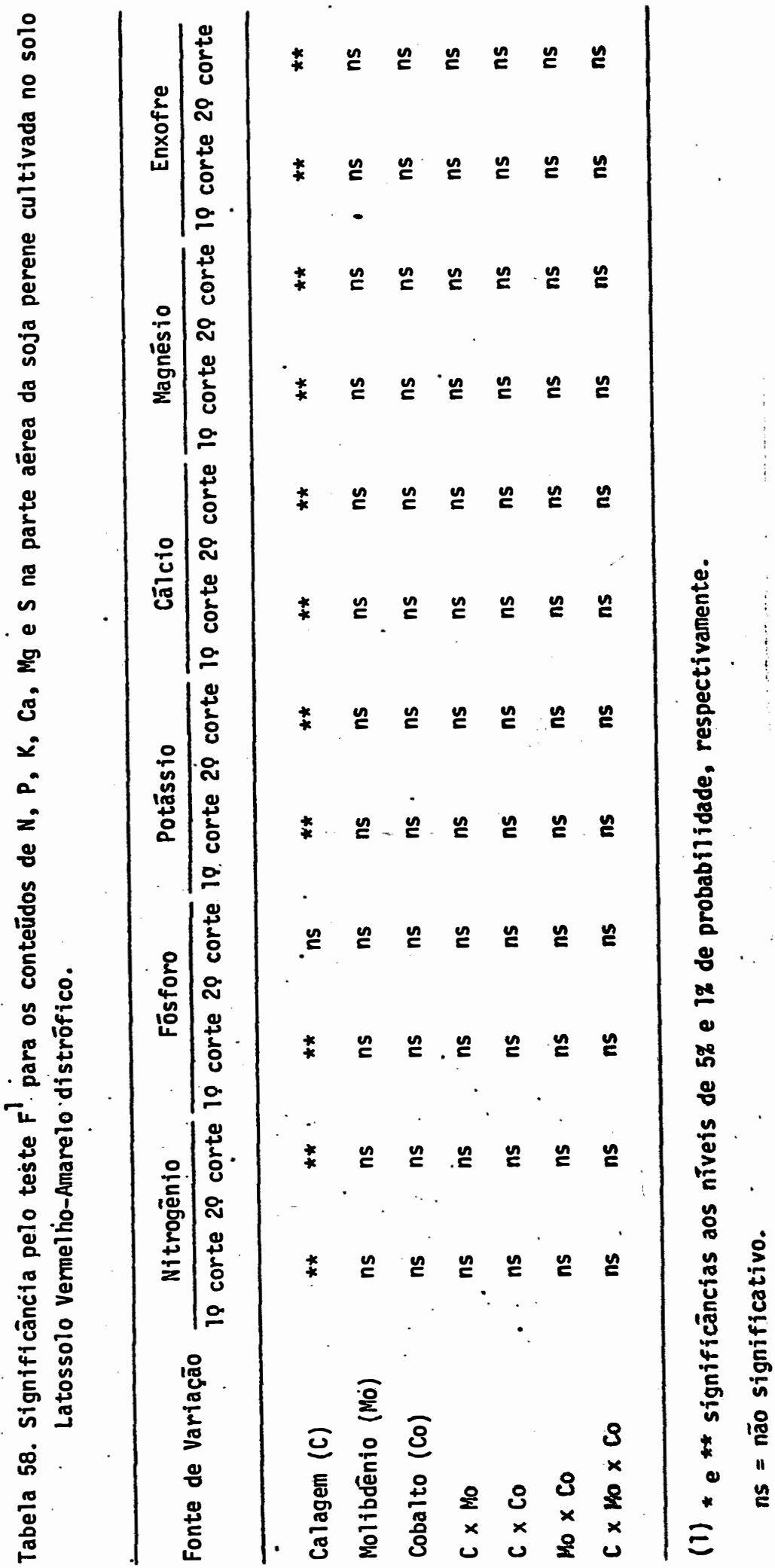




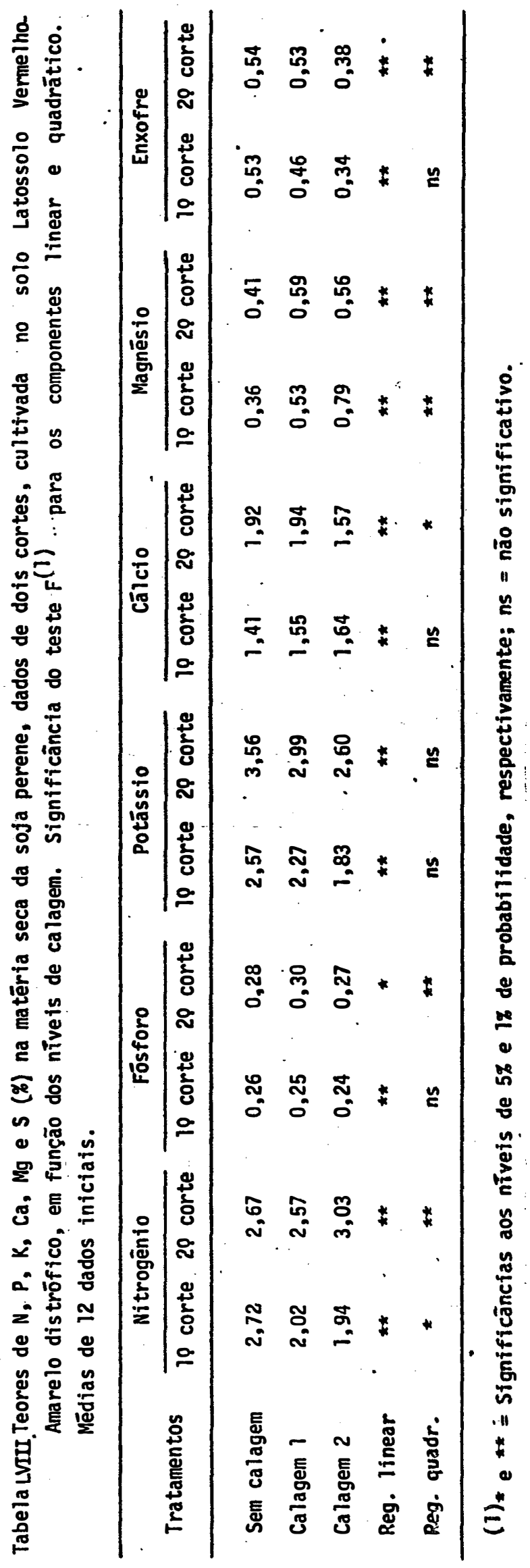




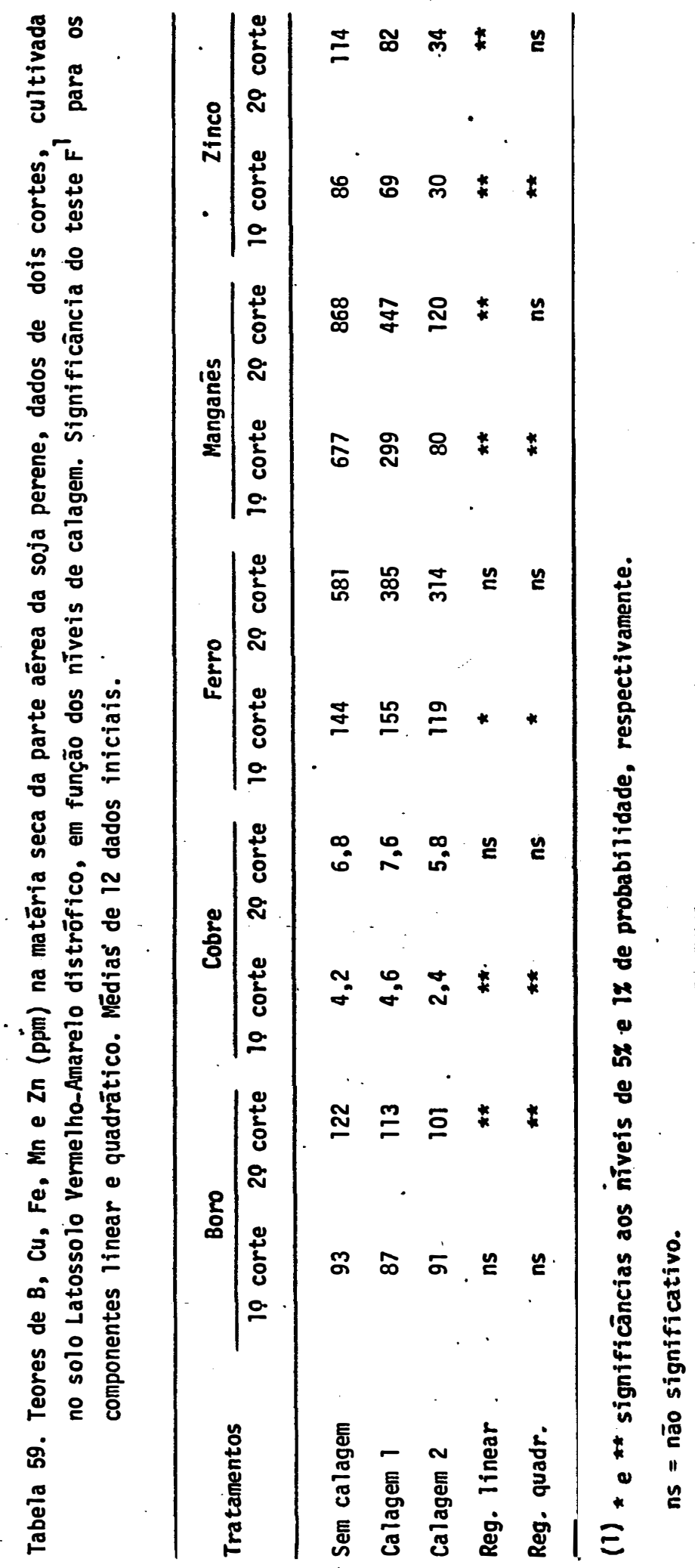




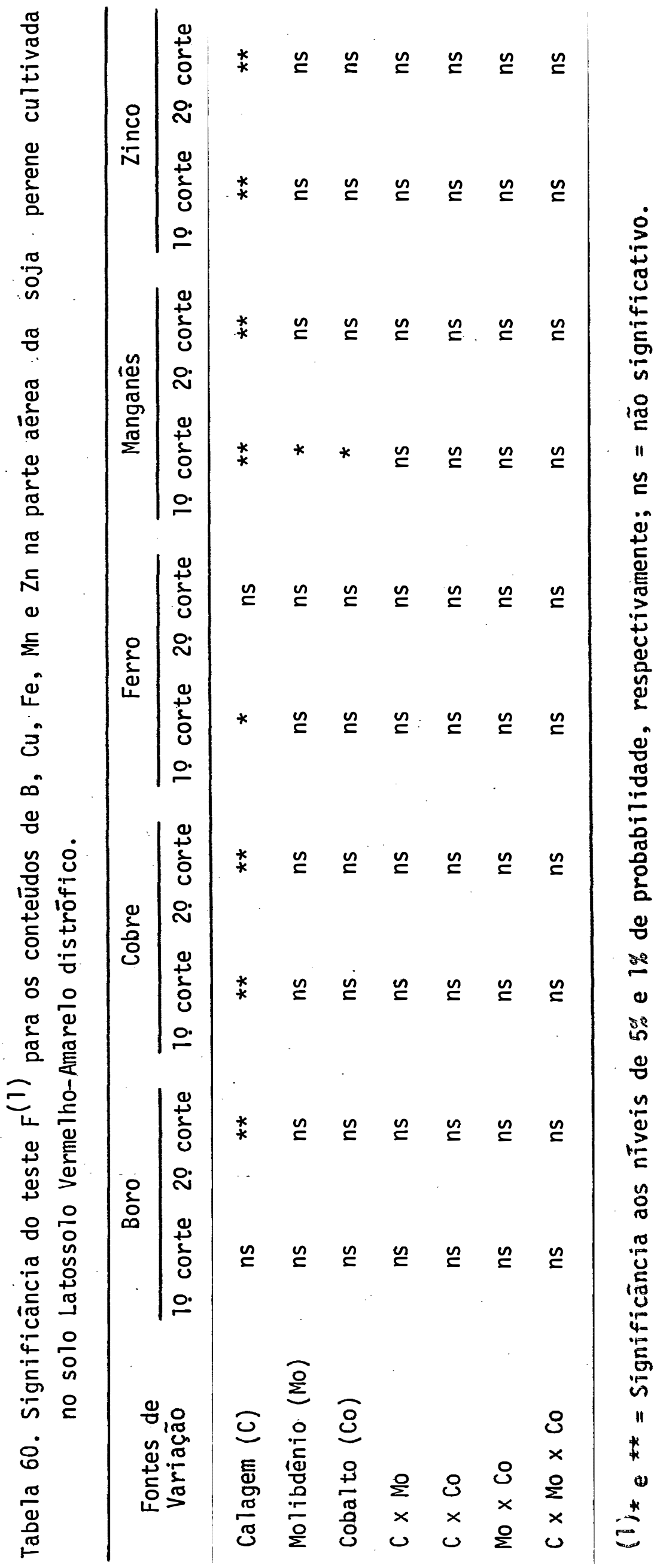




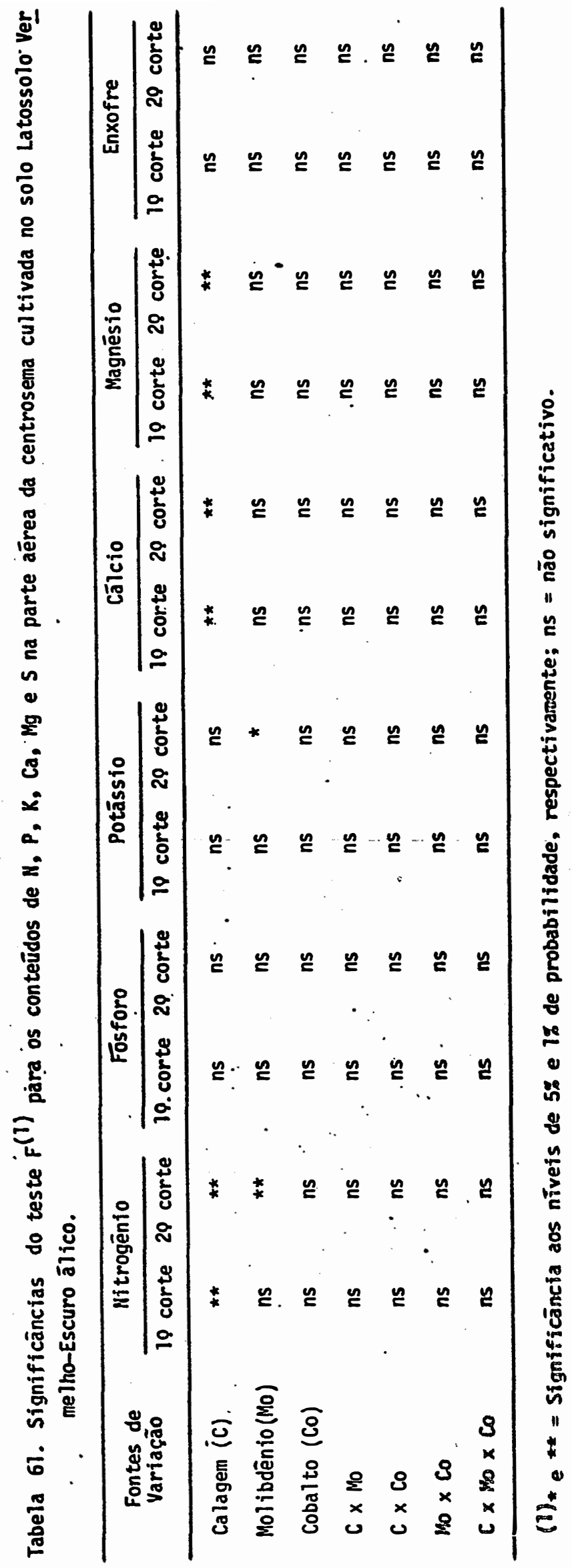




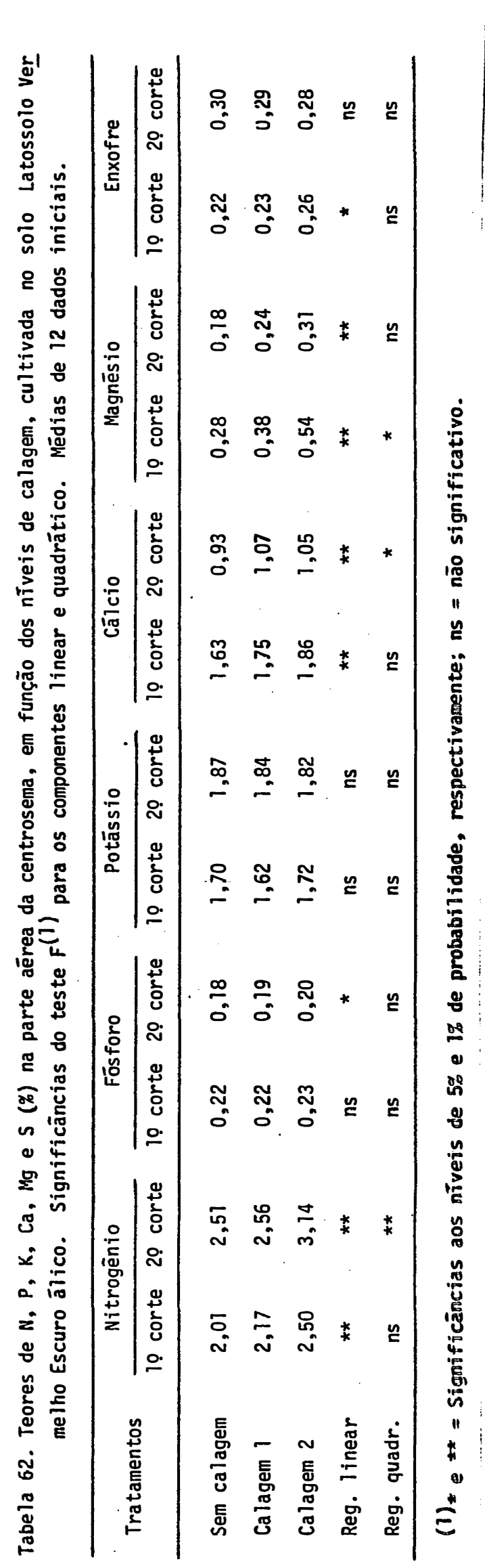




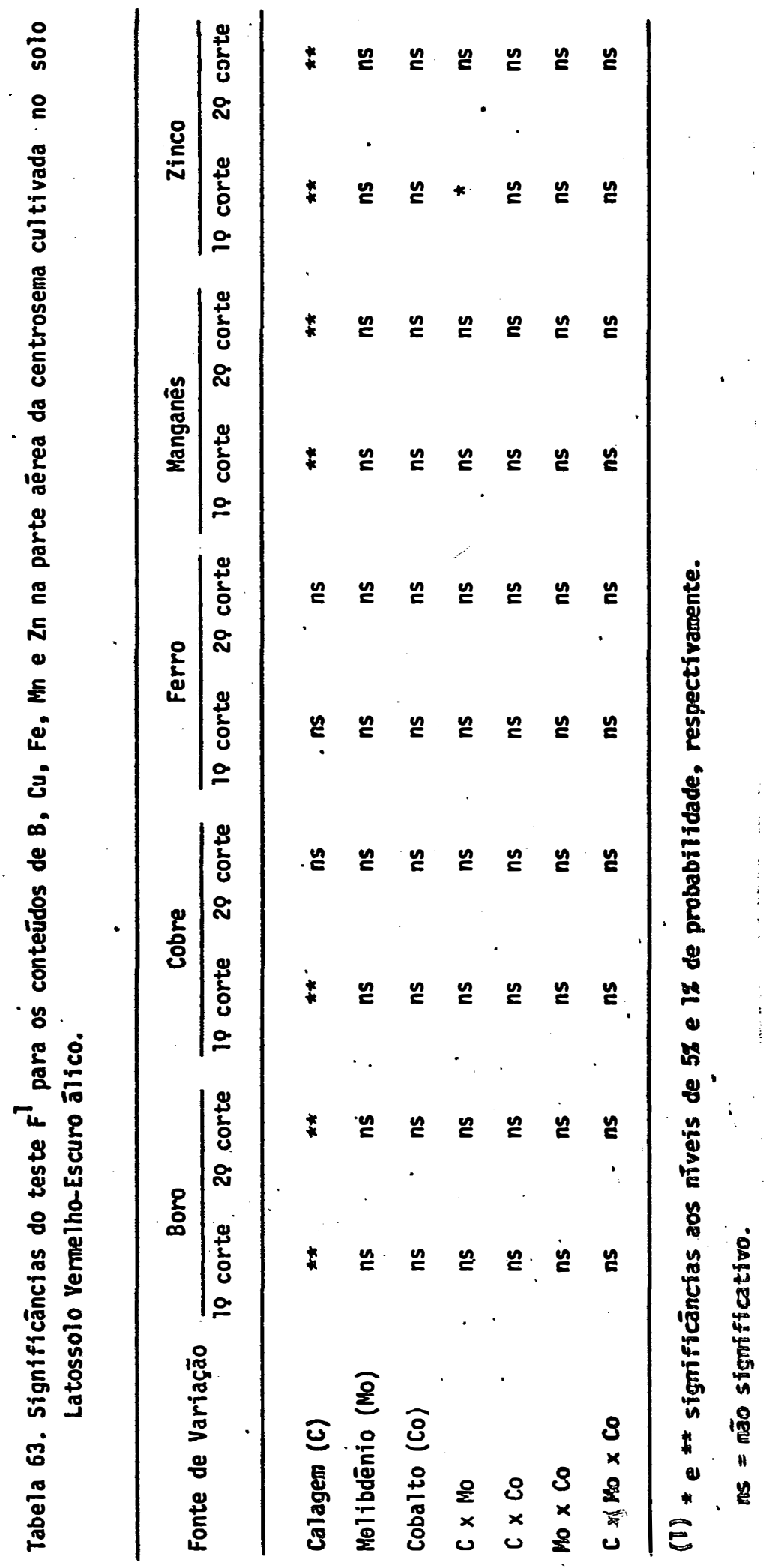




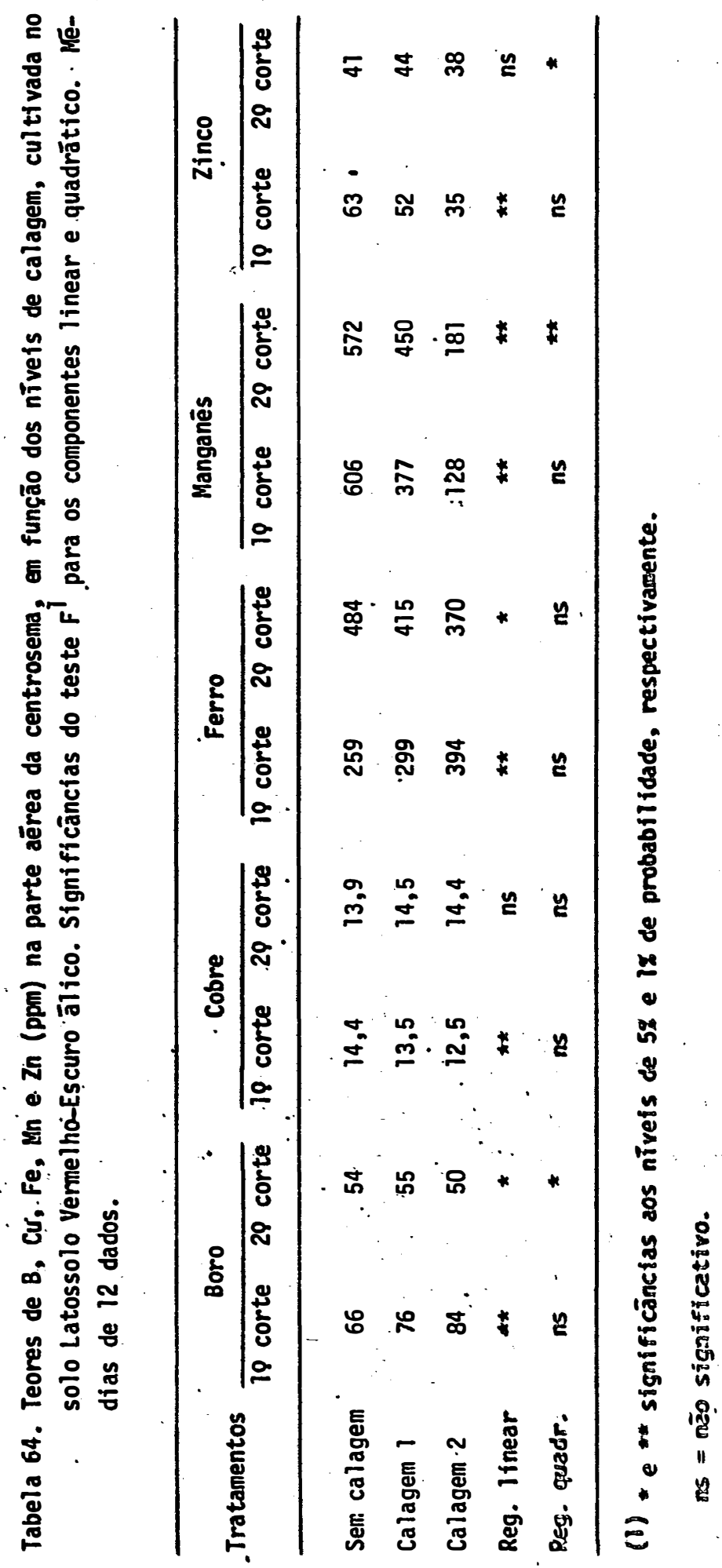


Tabela 65. Equações de regressão para os efeitos de niveis de calagem em função dos tratamentos sem ou com aplicação de Molibdênio ou Cobalto, centrosema cultivada no solo LEa.

Variāvel dependente

Ferro (ppm) - 10 corte

Zinco $(\mathrm{ppm})-19$ corte

Ferro (ppm) - 29 corte
Tratamentos

Calagem sem Mo

com Mo

Calagem sem Mo

com Mo

Calagem sem Co

com Co
Equação de regressão

$\hat{y}=249,6+1,93 x$

ns

$\bar{y} \bar{e}$ a estimativa da variāvel dependente e $x$ as quantidades de calcărio utilizadas; ns anālise de regressão não significativa. 


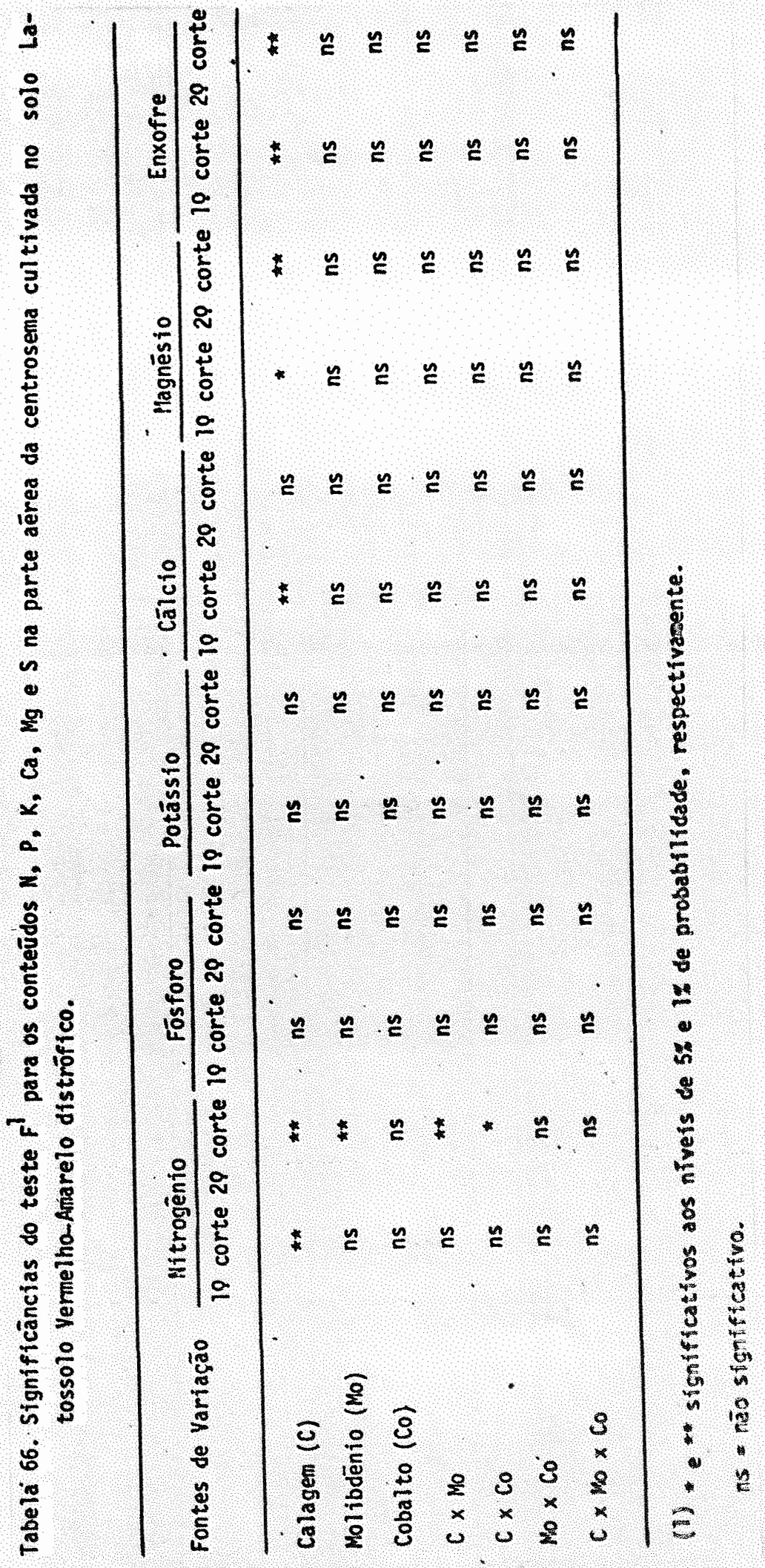




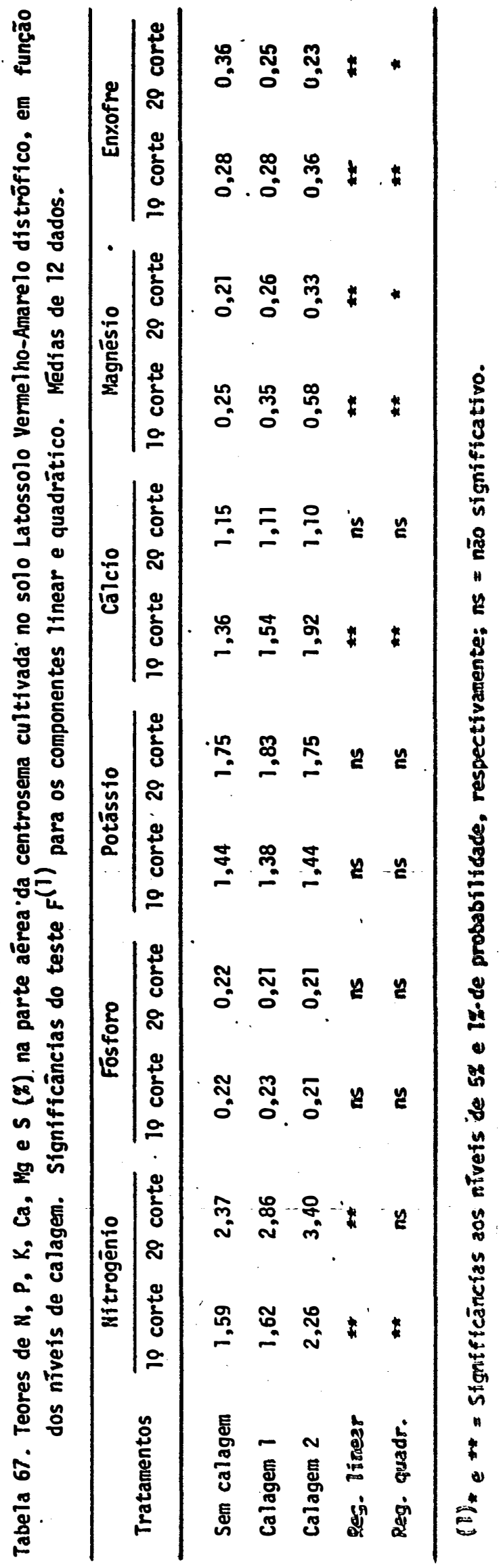


Tabela 68. Teores de nitrogēnio (\%), em função dos níveis de calagem e mediante a aplicação ou não de molibdênio (Mo) ou de cobalto (Co).

$$
\text { Nitrogēnio }(\%)-20 \text { corte }
$$

Sem Mo Com Mo Sem Co. Com Co

$\begin{array}{lllll}\text { Sem calagem } & 2,17 \mathrm{~b} & 2,56 \mathrm{a} & 2,56 \mathrm{a} & 2,17 \mathrm{~b} \\ \text { Calagem 1 } & 2,50 \mathrm{~b} & 3,22 \mathrm{a} & 2,84 \mathrm{a} & 2,88 \mathrm{a} \\ \text { Calagem 2 } & 3,37 \mathrm{a} & 3,42 \mathrm{a} & 3,37 \mathrm{a} & 3,42 \mathrm{a}\end{array}$

Médias seguidas pelas mesmas letras, comparadas na linha não diferem entre si pelo teste de Tukey a $5 \%$. 
Tabela 69. Equações de regressão para os efeitos dos nĩveis de calagem em função da aplicação ou não de cobalto ou molibdênio

$$
\begin{aligned}
\text { Nitrogênio }-20 \text { corte Calagem sem cobalto } & \bar{y}=2,52+0,01 x \\
\text { com cobal to } & \bar{y}=2,20+0,018 x
\end{aligned}
$$

Nitrogênio - 20 corte Calagem sem molibdēnio $\bar{y}=2,17+0,0019 x+0,00022 x^{2}$ $(\%)$ com molibdēnio $\bar{y}=2,63+0,013 x$

Manganēs - 10 corte Calagem sem molibdênio $\bar{y}=520,1-5,85 x$ (ppm) com molibdēnio $\bar{y} \approx 495,6-2,61 x-0,043 x^{2}$

onde $\bar{y}$ representa a variāvel dependente $e \times 0$ nĩvel de calagem dentro dos limites estudados. 


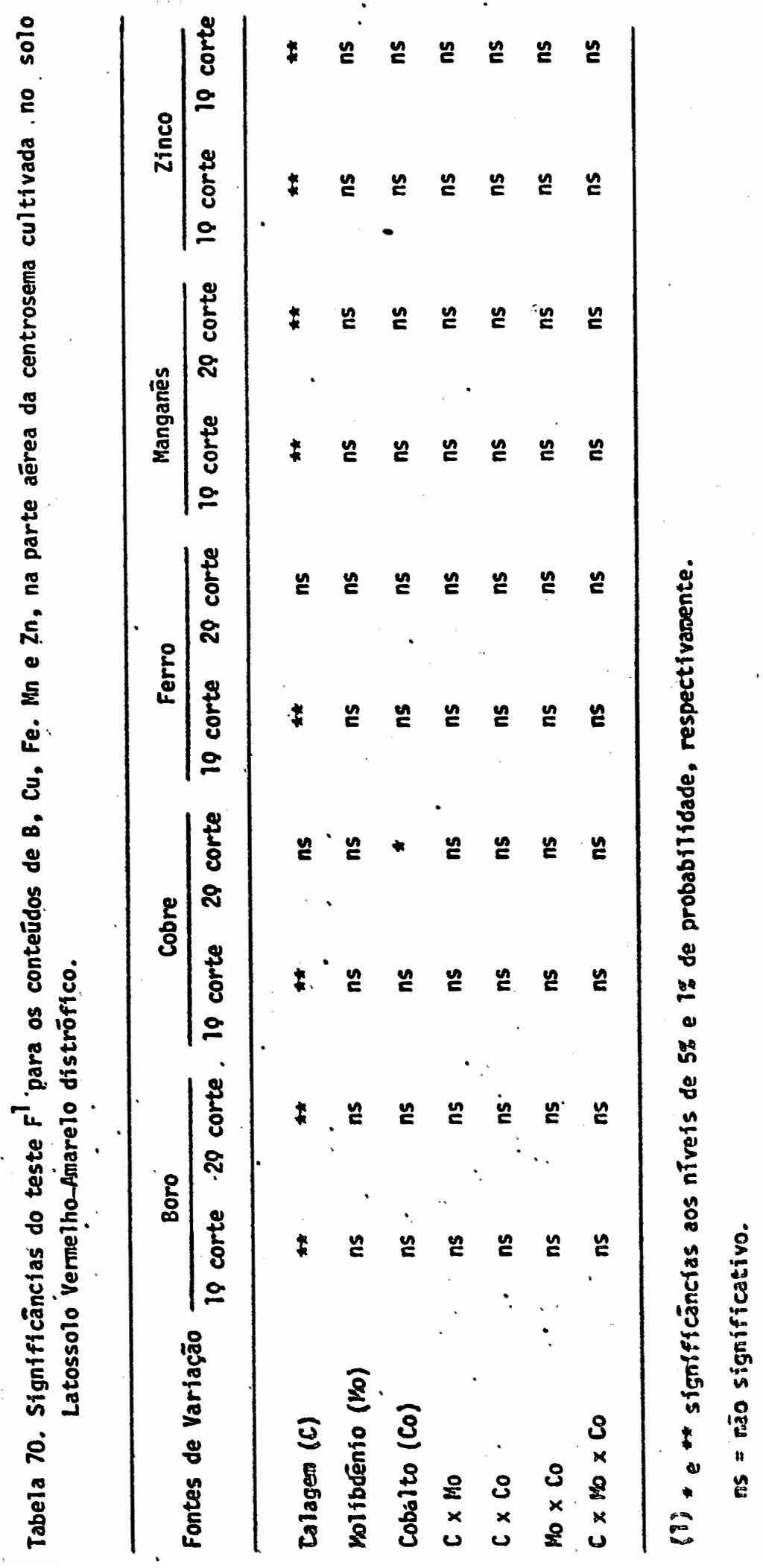




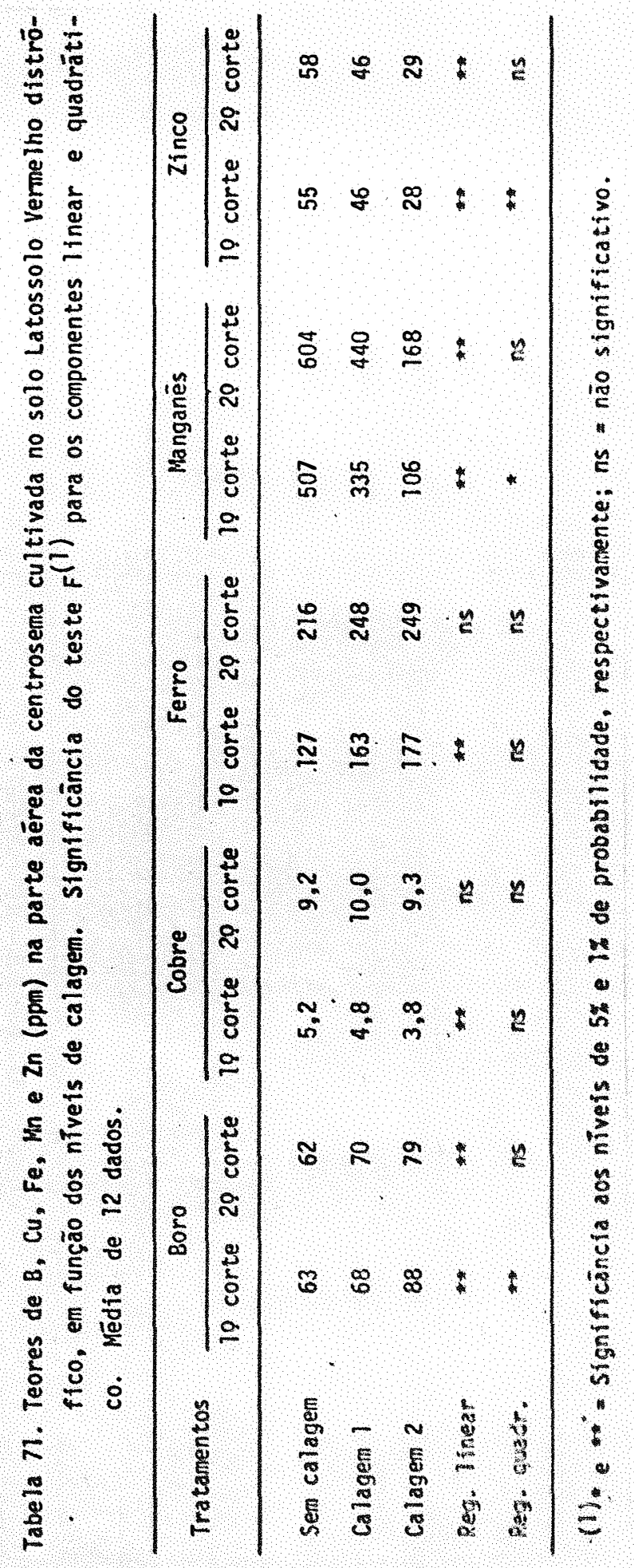




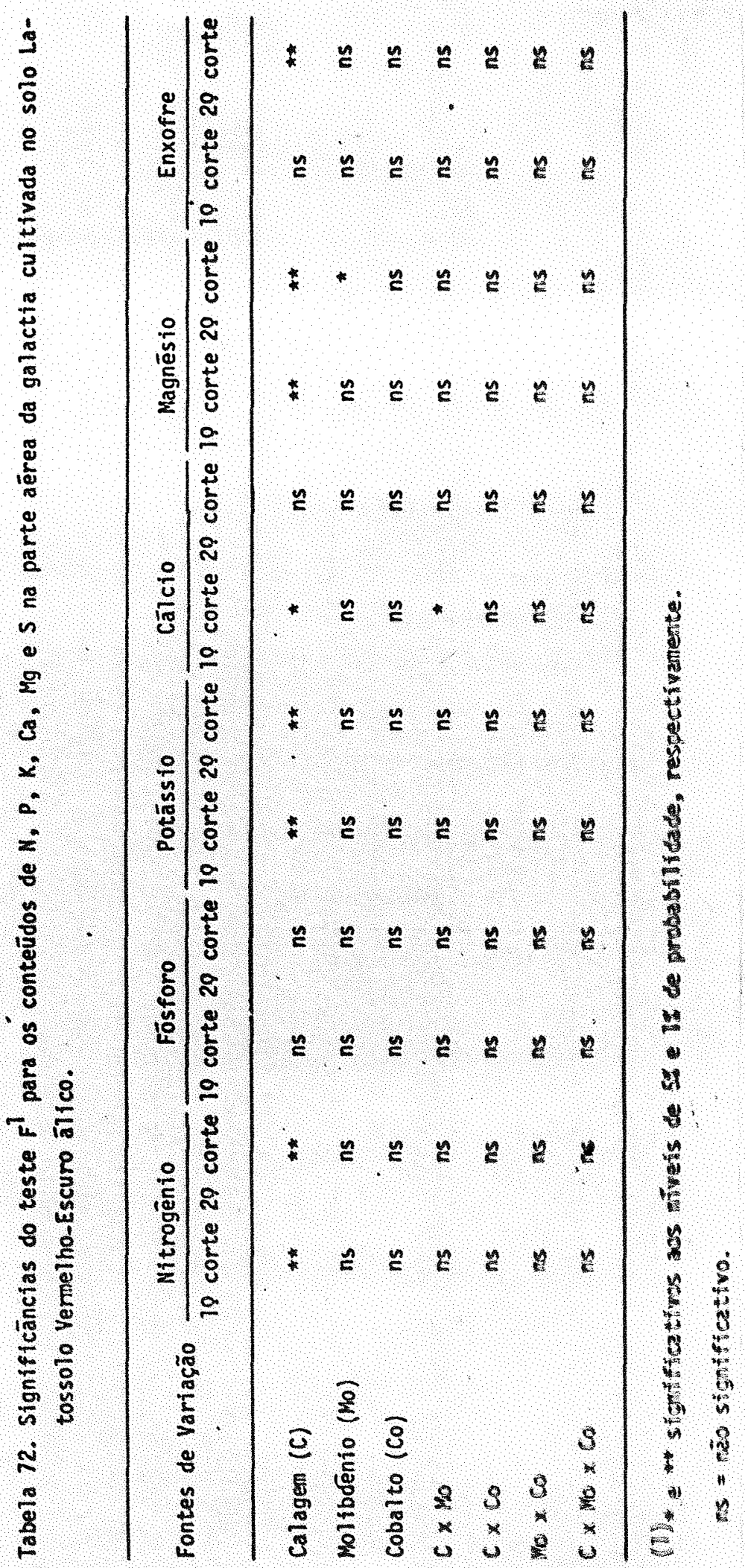




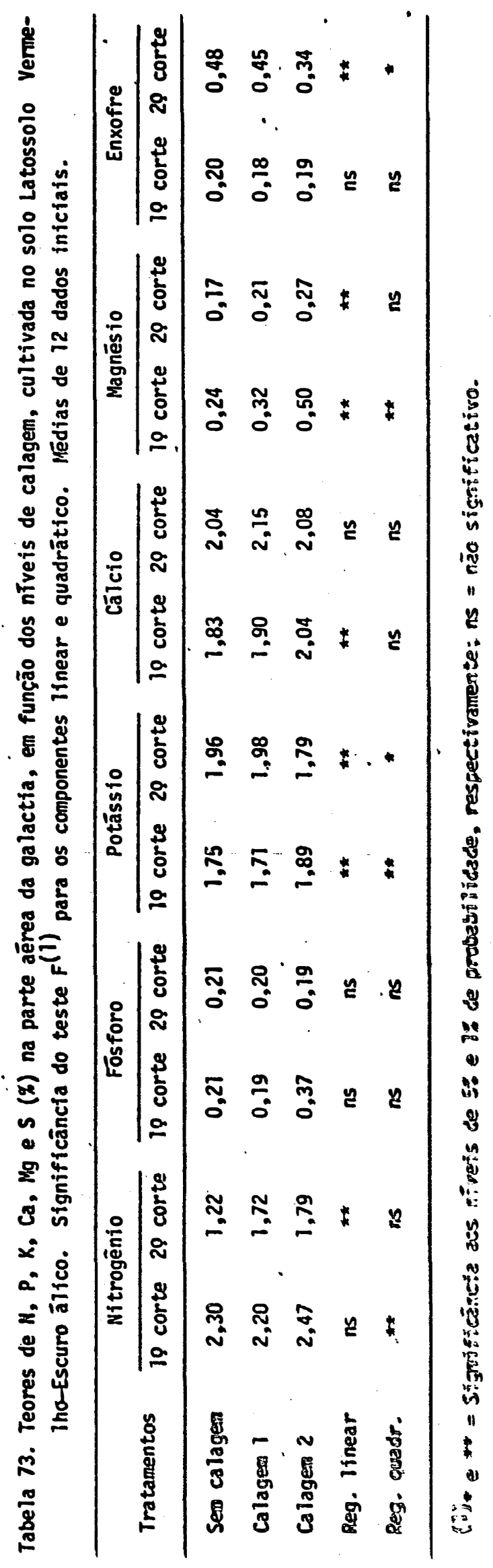


Tabela 74. Teor de Ca (\%) em função dos nĩveis de calagem, mediante a aplicação ou não de molibdēnio para galactia cultivada no solo Latossolo Vermelho Escuro älico.

\begin{tabular}{|c|c|c|c|}
\hline \multirow{3}{*}{ Tratamentos } & \multicolumn{3}{|c|}{$c \bar{a} 1 c$ i $0 \quad(\%)$} \\
\hline & \multicolumn{3}{|c|}{$10 \mathrm{Corte}$} \\
\hline & Sem Molibdēnio & Com & Molibdênio \\
\hline Sem Calagem & $1,89 a$ & & $1,83 a$ \\
\hline Calagem 1 & $1,92 a$ & & $1,89 \mathrm{a}$ \\
\hline Calagem 2 & 1,92 b & & $2,04 a$ \\
\hline
\end{tabular}

Médias seguidas pela mesma letra em cada linha não diferem entre si pelo teste de Tukey à $5 \%$. 


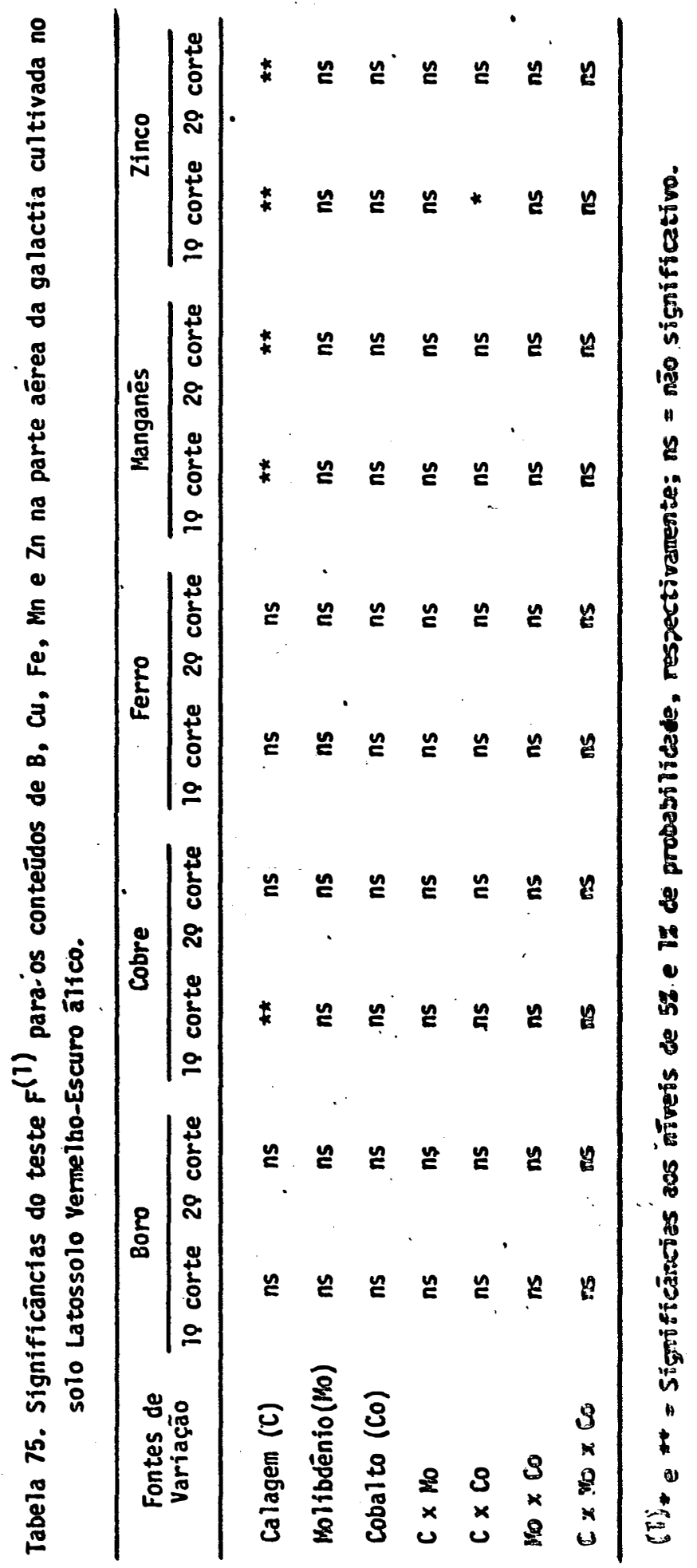




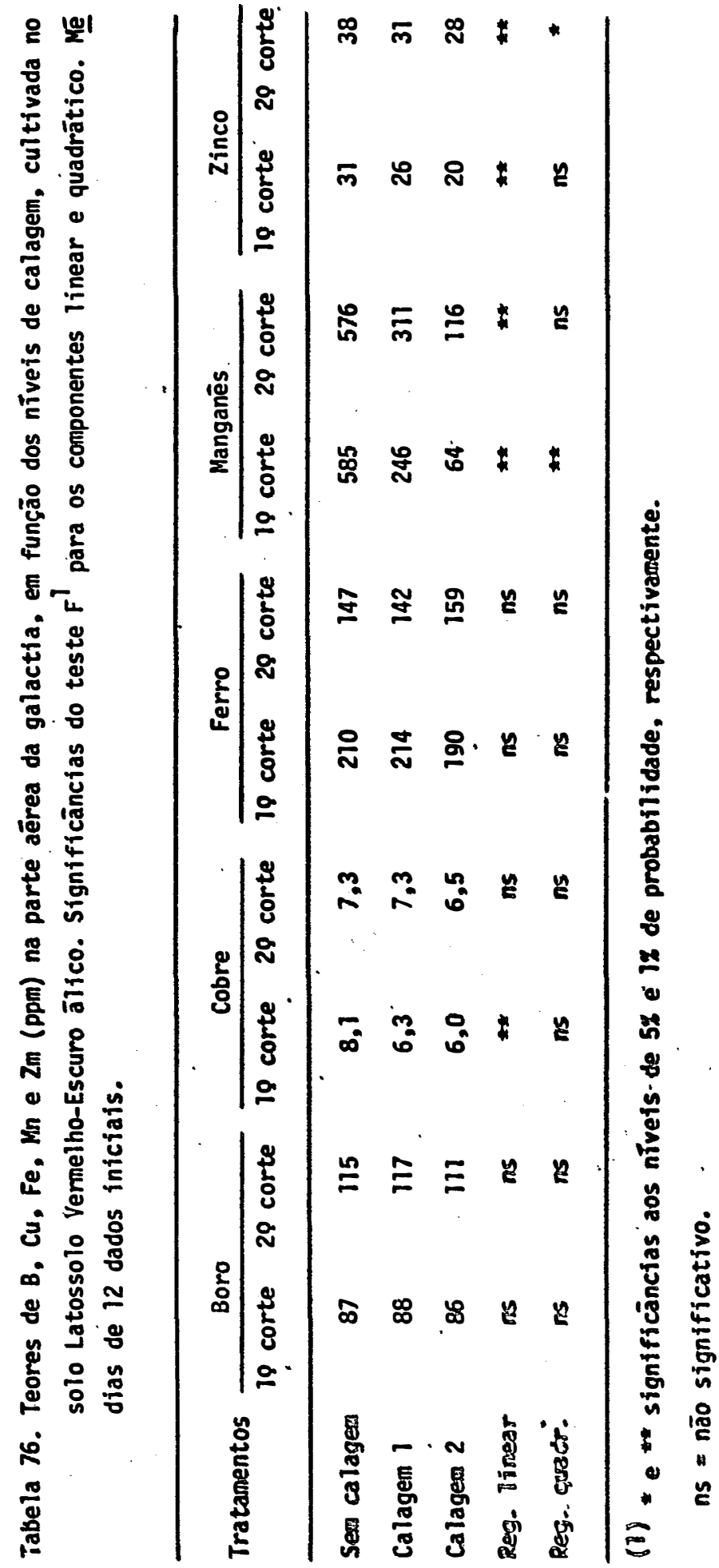


Tabela 77. Teores de zinco (ppm) na parte aērea da galactia cultivada no solo Latossolo Vermelho-Escuro-āiico em função da aplicação da calagem e de cobalto.

T̈ratamentos

Zinco - ppm

Sem Cobalto Com Cobalto

Sem ca?agem

30 a

32 a

Calagem 1

$23 \mathrm{~b}$

30 a

Calagem 2

$18 \mathrm{~b}$

22 a

Médias seguidas pela mesma letra em cada linha não diferem en tre si pelo teste de Tukey a $5 \%$. 


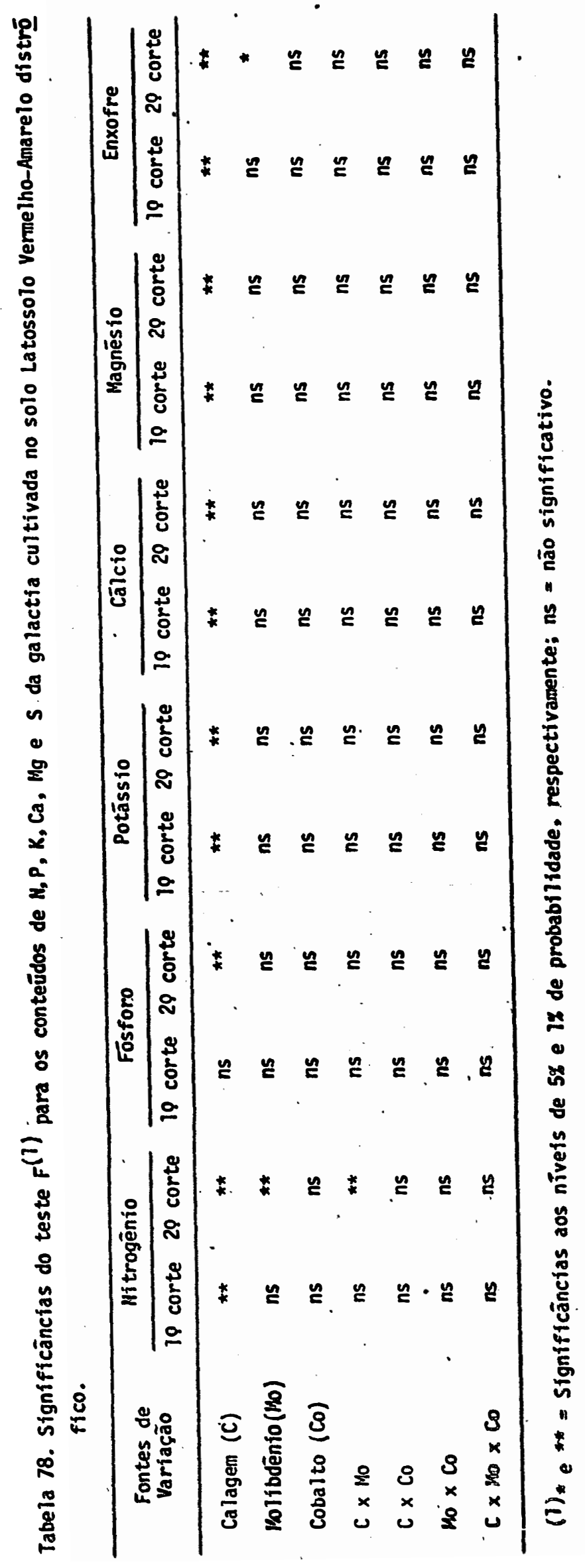




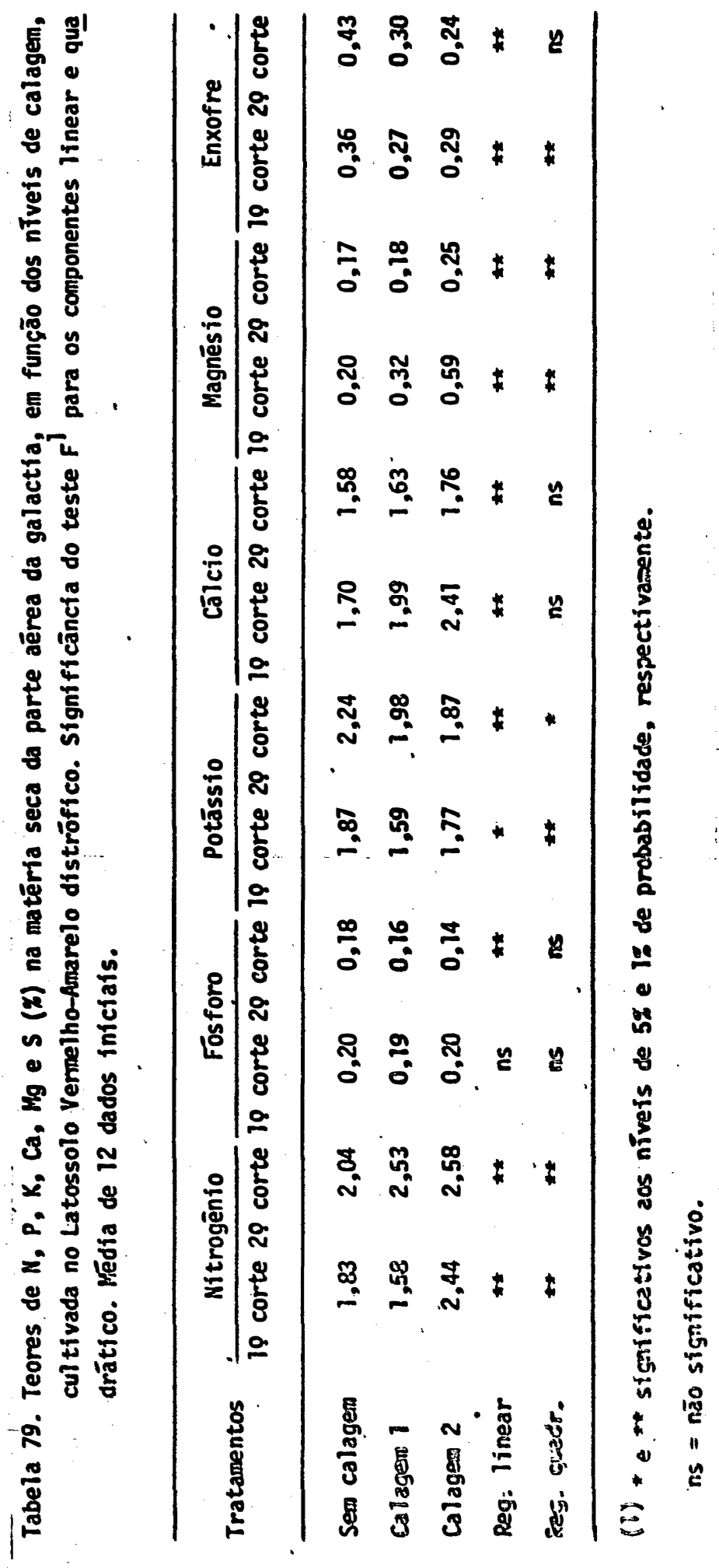


Tabela 80. Teores de Nitrogênio $(\%)$ em galactia cultivada no solo Latosso 10 Vermelho-Amarelo distrófico, em funçăo dos níveis de calagem e mediante a aplicação ou não de Molibdênio. Dados do se gundo corte.

\begin{tabular}{ccc}
\hline Tratamentos & Nitrogènio $(\%)$ \\
\hline Sem calagem & $1,77 \mathrm{~b}$ & Com Mo \\
Calagem 1 & $2,24 \mathrm{~b}$ & $2,30 \mathrm{a}$ \\
Calagem 2 & $2,52 \mathrm{a}$ & $2,82 \mathrm{a}$ \\
\end{tabular}

Médias seguidas das mesmas letras em cada linha, näo diferem entre si pe10 teste de Tukey a $5 \%$. 


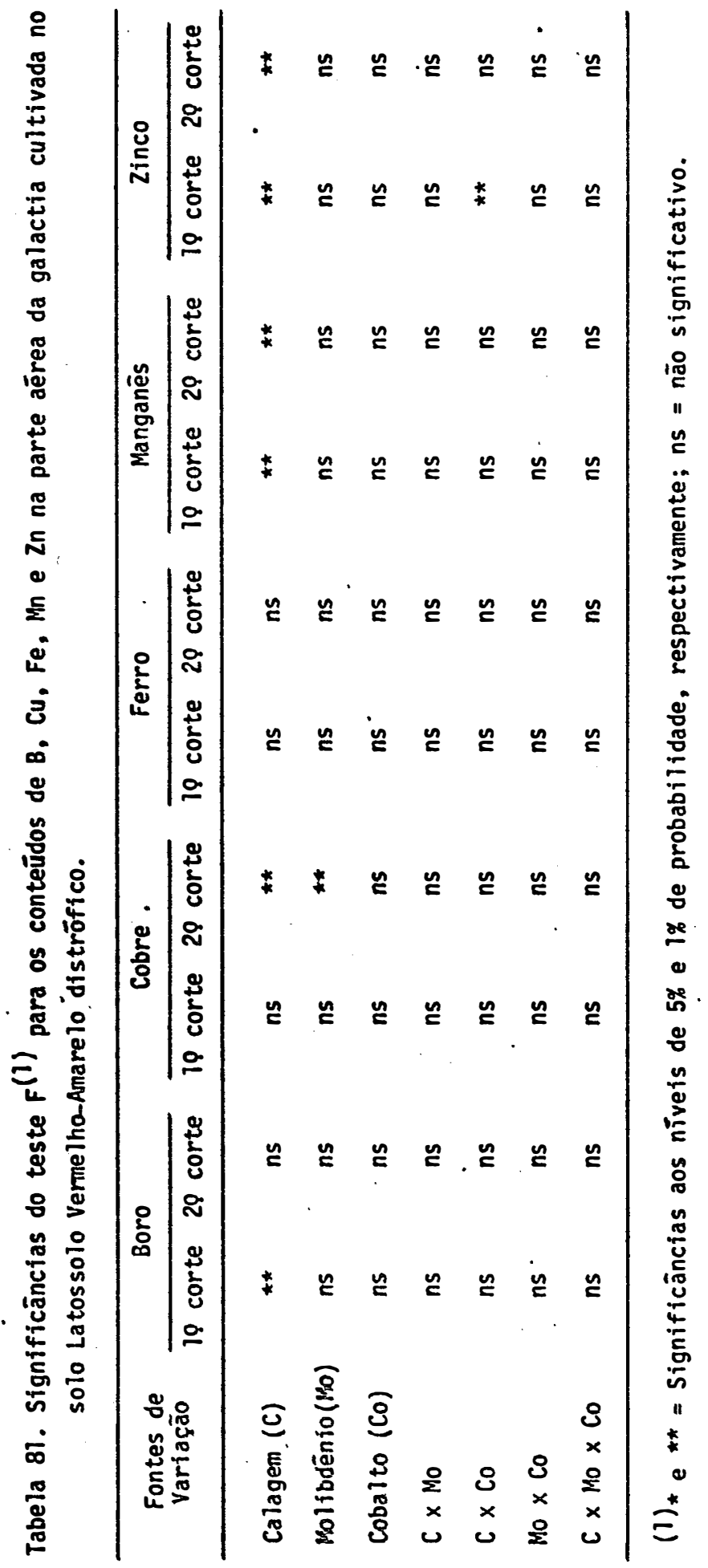




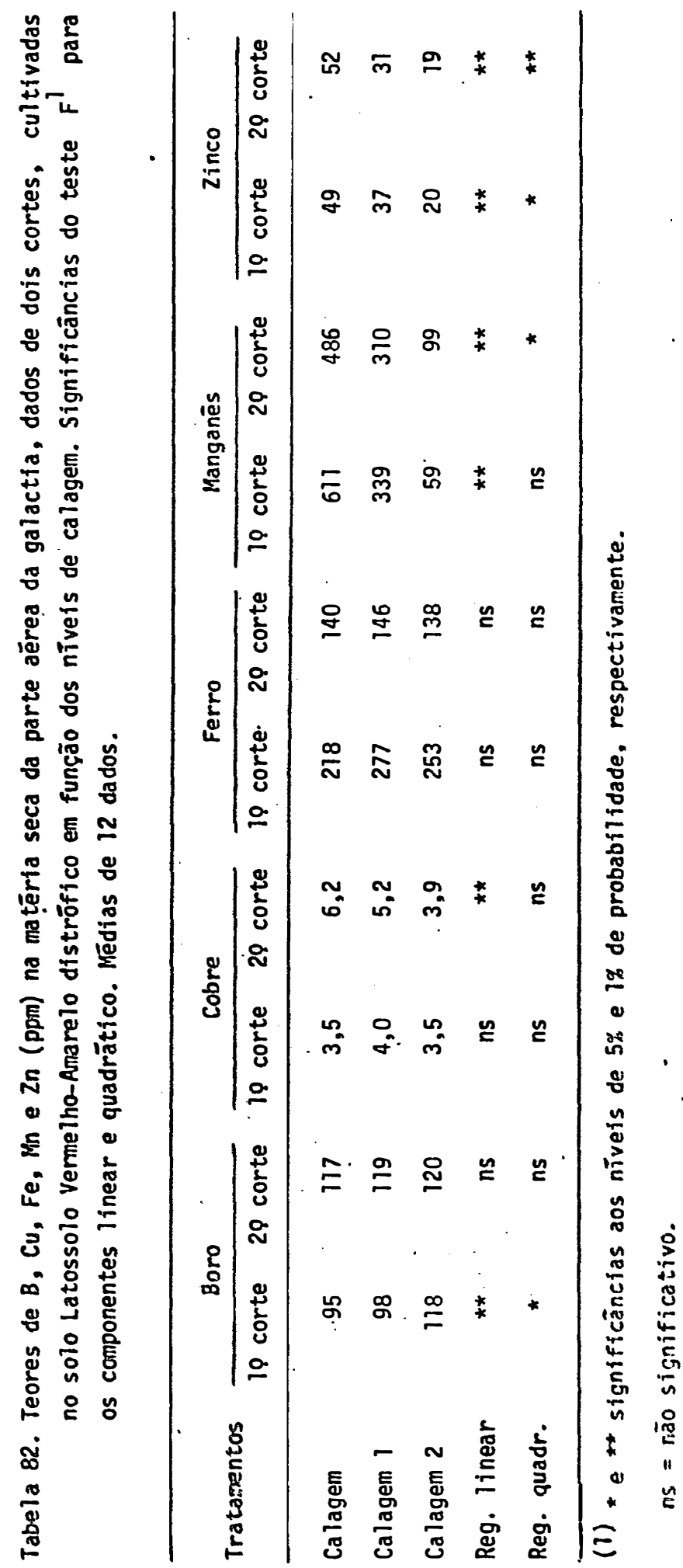


Tabela 83. Teores de zinco (ppm) na parte aērea da galactia cultivada no solo Latossolo Vermelho-Amarelo distrōfico, em função dos nīveis de calagem e median te a aplicação ou não de cobalto. Dados do primei corte.
Tratamentos
Zinco - ppm

Sem Cobalto

Sem calagem

Calagem 1

Cal agem 2
53 a

36 a

18 a
Com Cobalto

$47 \mathrm{~b}$

38 a

21 a

Médias seguidas da mesma letra em cada linha não diferem entre si pelo teste de Tukey a $5 \%$. 
Tabela 84. Significāncias para o teste $F^{(1)}$ para as quantidades totais de nitrogēnio acumuladas na parte aérea da soja-perene cultivada nos solos Latossolo Vermelho-Amarelo-distrófico (LVd) e no so10 Latossolo Vermelho-Escuro-ālico (LEa).

\begin{tabular}{|c|c|c|c|c|}
\hline \multirow{3}{*}{$\begin{array}{l}\text { Fontes de } \\
\text { Variação }\end{array}$} & \multicolumn{4}{|c|}{ Nitrogēnio Total } \\
\hline & \multicolumn{2}{|c|}{ LVd } & \multicolumn{2}{|c|}{ LEa } \\
\hline & 10 Corte & 20 Corte & 10 Corte & 20 Corte \\
\hline Ca lagem (C) & $\star \star$ & $\star \star$ & ** & $\star \star$ \\
\hline Molibdēnio (Mo) & ns & ns & ns & ns \\
\hline Cobalto (Co) & ns & ns & ns & ns \\
\hline $\mathrm{C} \times \mathrm{Mo}$ & ns & ns & * & ns \\
\hline $\mathrm{C} \times \mathrm{Co}$ & ns & ns & ns & ns \\
\hline Mo $\times$ Co & ns & ns & ns & ns \\
\hline$C \times$ Mo $\times$ Co & ns & ns & ns & ns \\
\hline C dentro sem Mo & - & - & $\star \star$ & - \\
\hline C dentro com Mo & - & - & $\star \star$ & - \\
\hline Mo dentro sem C & - & - & ns & - \\
\hline Mo dentro $C_{1}$ & - & - & $\star$ & - \\
\hline Mo dentro $C_{2}$ & - & - & $* *$ & - \\
\hline
\end{tabular}

(1)* e ** = Significativo aos nīveis de $5 \%$ e $1 \%$ de probabilidade, respectivamente; $n s=$ não significativo; - = interação não significativa. 
Tabela 85. Quantidades totais de nitrogēnio acumuladas (mg/vaso) na parte aérea da soja perene cultivada nos solos Latossolo Vermelho Amare 10-distrófico (LVd) e Latossolo Vermetho - Escuro - àlico (LEa). Significanncias do teste $F^{(1)}$ para os componentes 1 inear e quadrātico. Médias de 12 dados iniciais.

\begin{tabular}{|c|c|c|}
\hline \multirow{3}{*}{ Tratamentos } & \multicolumn{2}{|c|}{ Nitrogēnio Total Acumulado } \\
\hline & LVd & LEa \\
\hline & 10 corte & 10 corte \\
\hline
\end{tabular}

Sem calagem (C)

133,6

34,9

171,0

41,0

Calagem 1

142,5

64,1

203,0

93,0

Calagem 2

181,5

199,3

235,0

178,0

Reg. Tinear

** $\quad$ **

**

$\star \star$

Reg. quadrātica

(1) * e $\mathrm{e}^{* *}=$ Significāncias aos níveis de $5 \%$ e $1 \%$ de probabilidade, respectivamente; $n s=$ não significativo. 
Tabela 86. Produção de matéria seca ( $g / v a s o)$ e quantidades totais de nitrogēnio (mg/vaso) da soja-perene cultivada no solo LEa, em função dos nĩveis de calagem $(1)$ e mediante a aplicação ou não de molibdēnio.

Tratamentos Matéria seca - 10 corte $\mathrm{N}$ total - 10 corte

Sem Mo Com Mo Sem Mo Com Mo

$\begin{array}{lllll}\text { Sem calagem } & 5,17 \mathrm{~b} & 6,25 \mathrm{a} & 172 \mathrm{a} & 180 \mathrm{a} \\ \text { Calagem 1 } & 6,42 \mathrm{a} & 6,46 \mathrm{a} & 190 \mathrm{~b} & 210 \mathrm{a} \\ \text { Calagem 2 } & 7,53 \mathrm{~b} & 8,32 \mathrm{a} & 222 \mathrm{~b} & 257 \mathrm{a}\end{array}$

(1) Médias seguidas pelas mesmas letras comparadas na linha não diferem en tre si pelo teste de Tukey a $5 \%$. 
Tabela 87. Significâncias para o teste $F^{1}$ para as quantidades totais de nitrogênio acumuladas na parte aérea da centrosema cultivada nos solos Latossolo Vermelho-Amarelo distrófico (LVd) e no so 10 Latossolo Vermelho-Escuro álico (LEa).

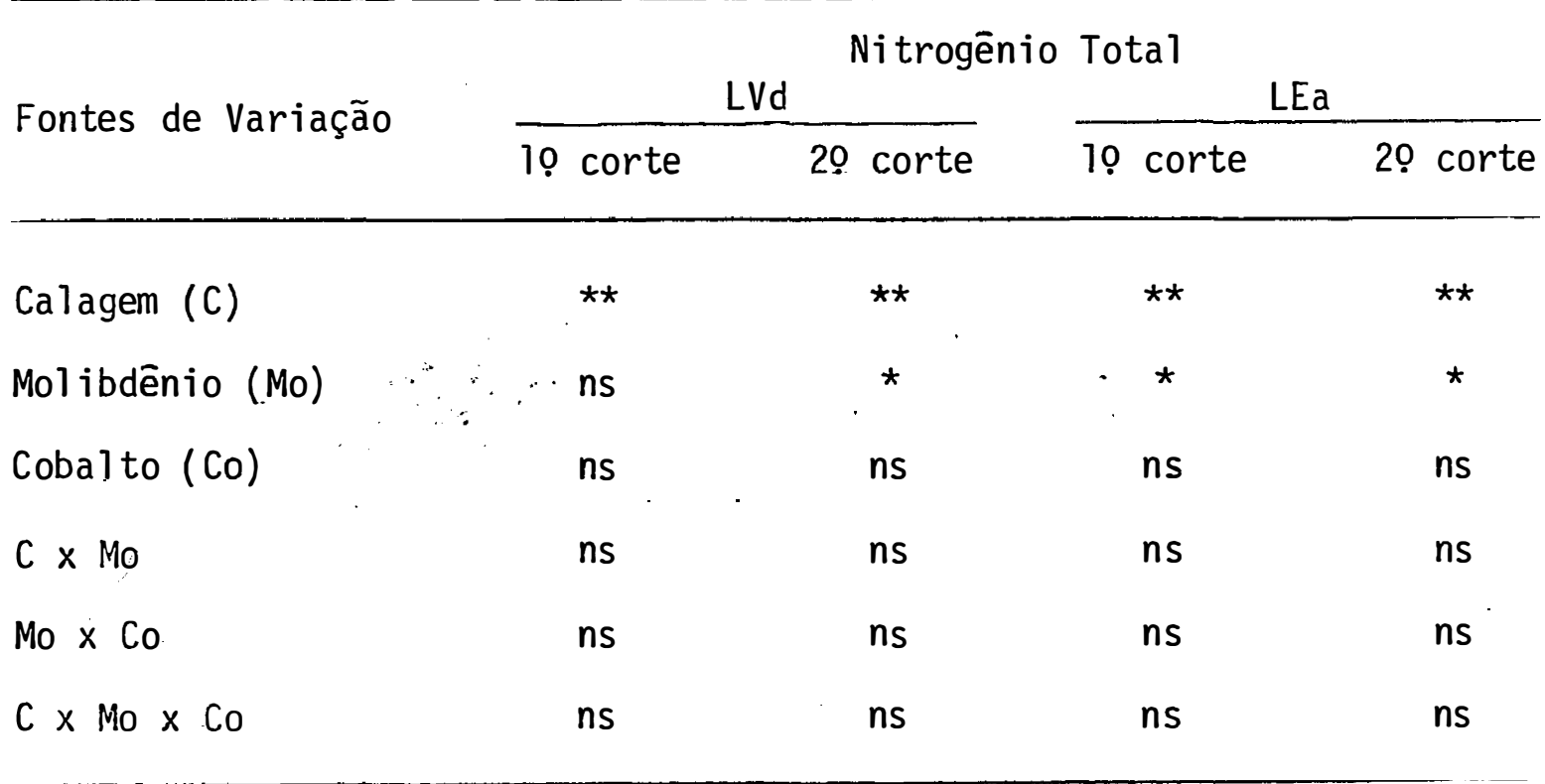

(1)* e ** significativos aos nīveis de $5 \%$ e $1 \%$ de probabilidade, respecti vamente.

ns = não significativo. 
Tabela 88. Quantidades totais de nitrogēnio acumuladas (mg/vaso) na parte aérea da centrosema cultivada nos solos Latossolo Vermelho-Ama relo distrōfico. (LVd) e Latossolo Vermelho-Escuro ālico (LEa), em função dos nīveis de calagem. Significāncias do teste $F(1)$ para os componentes linear e quadrático. Médias de 12 dados iniciais.

\begin{tabular}{|c|c|c|c|c|}
\hline \multirow{3}{*}{ Tratamentos } & \multicolumn{4}{|c|}{ Nitrogēnio Total Acumulado } \\
\hline & \multicolumn{2}{|c|}{ LVd } & \multicolumn{2}{|c|}{ LEa } \\
\hline & 10 corte & 20 corte & 10 corte & 20 corte \\
\hline Sem calagem & 145,4 & 144,8 & 221,0 & 195,0 \\
\hline Calagem 1 & 152,8 & 221,6 & 238,0 & 223,0 \\
\hline Calagem 2 & 213,4 & 372,4 & 286,0 & 366,0 \\
\hline Reg. linear & $\star *$ & $\star \star$ & ** & $\star \star$ \\
\hline Reg. quadrātica & * & ns & ns & $\star \star$ \\
\hline
\end{tabular}

(1)* e $e^{*}=$ Significāncias aos nîveis de $5 \%$ e $1 \%$ de probabilidade, respectivamente; $n s=$ não significativo. 
Tabela 89. Quantidades de nitrogēnio acumuladas (mg/vaso) na parte aérea do centrosema, em função da aplicação ou não de Cobalto e Mo libdēnio.

Sem Cobalto

Sem Molibdēnio

Com Molibdēnio
$249 a A$

254bA
Com Cobalto

$238 \mathrm{aB}$

$305 \mathrm{aA}$

Médias seguidas pelas mesmas letras minūsculas, comparadas na linha, ou pelas mesmas letras maipusculas, comparadas na colu na, não diferem entre si pelo teste de Tukey a $5 \%$. 
Tabela 90 . Significāncias para o teste $\mathrm{F}^{(1)}$ para as quantidades totais de nitrogēnio acumuladas na parte aérea da galactia cultivada nos solos Latossolo Vermelho Amarelo distrófico (LVd) e no so1o Latossolo Vermelho Escuro ālico (LEa).

\begin{tabular}{|c|c|c|c|c|c|c|}
\hline \multirow{3}{*}{ Fontes de Variação } & \multicolumn{6}{|c|}{ Nitrogēnio Total } \\
\hline & \multicolumn{3}{|c|}{ LVd } & \multicolumn{3}{|c|}{ LEa } \\
\hline & 10 corte & 20 & corte & 10 corte & 20 & corte \\
\hline Ca lagem $(C)$ & ** & & $\star \star$ & $\star \star$ & & $\star \star$ \\
\hline Molibdēnio (Mo) & ns & & * & * & . & ns \\
\hline Cobalto (Co) & ns & & ns & ns & & ns \\
\hline$C \times$ Mo & ns & & ns. & ns & & ns \\
\hline $\mathrm{C} \times \mathrm{Co}$ & ns & & ns & ns & & ns \\
\hline Mo $\times$ Co & ns & & ns & ns & & ns \\
\hline$C \times$ Mo $\times C o$ & ns & & ns & ns & . & ns \\
\hline
\end{tabular}

$(1)_{*} e^{* *}=$ Significāncias aos nĩveis de $5 \%$ e $1 \%$ de probabilidade, res pectivamente; $n s$ = não significativo. 
Tabela 91. Quantidades totais de nitrogēnio acumuladas (mg/vaso) na parte aérea da galactia cultivada nos solos Latossolo Vermelho-Amare 10 distrófícó (LVd) e no solo Latossolo Vermelho-Escuro ālico (LEa), em função dos nīveis de calagem. Significâncias do tes te $F^{(i)}$ para os componentes linear e quadrätico. Médias de $\overline{1}$ dados iniciais.

\begin{tabular}{|c|c|c|c|c|}
\hline \multirow{3}{*}{ Tratamentos } & \multicolumn{4}{|c|}{ Nitrogênio total acumulado } \\
\hline & \multicolumn{2}{|c|}{ LVd } & \multicolumn{2}{|c|}{ LEa } \\
\hline & 10 Corte & 20 Corte & 10 Corte & 20 Corte \\
\hline Sem calagem & 131,0 & 104,4 & 191 & 54 \\
\hline Calagem 1 & 126,5 & 193,1 & 190 & 85 \\
\hline Calagem 2 & 173,4 & 229,9 & 223 & 120 \\
\hline Reg. linear & ** & $\star \star$ & $\star \star$ & ** \\
\hline Reg. quadrātica & ** & ** & $\star \star$ & ns \\
\hline
\end{tabular}

(1) * e ** significāncias aos nîveịs de $5 \%$ e $1 \%$ de probabilidade, respectivamente; $n s=$ não significativo. 


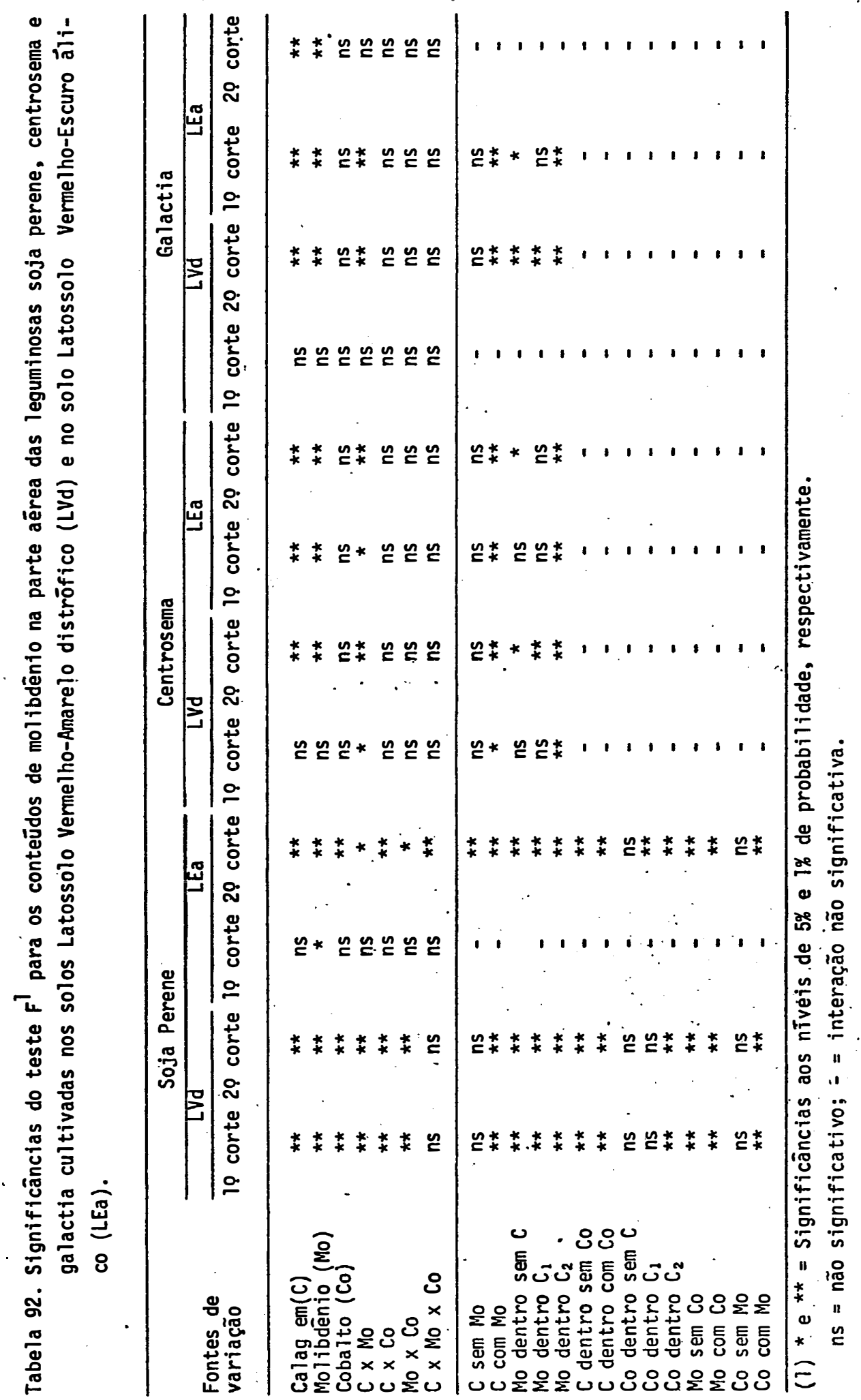




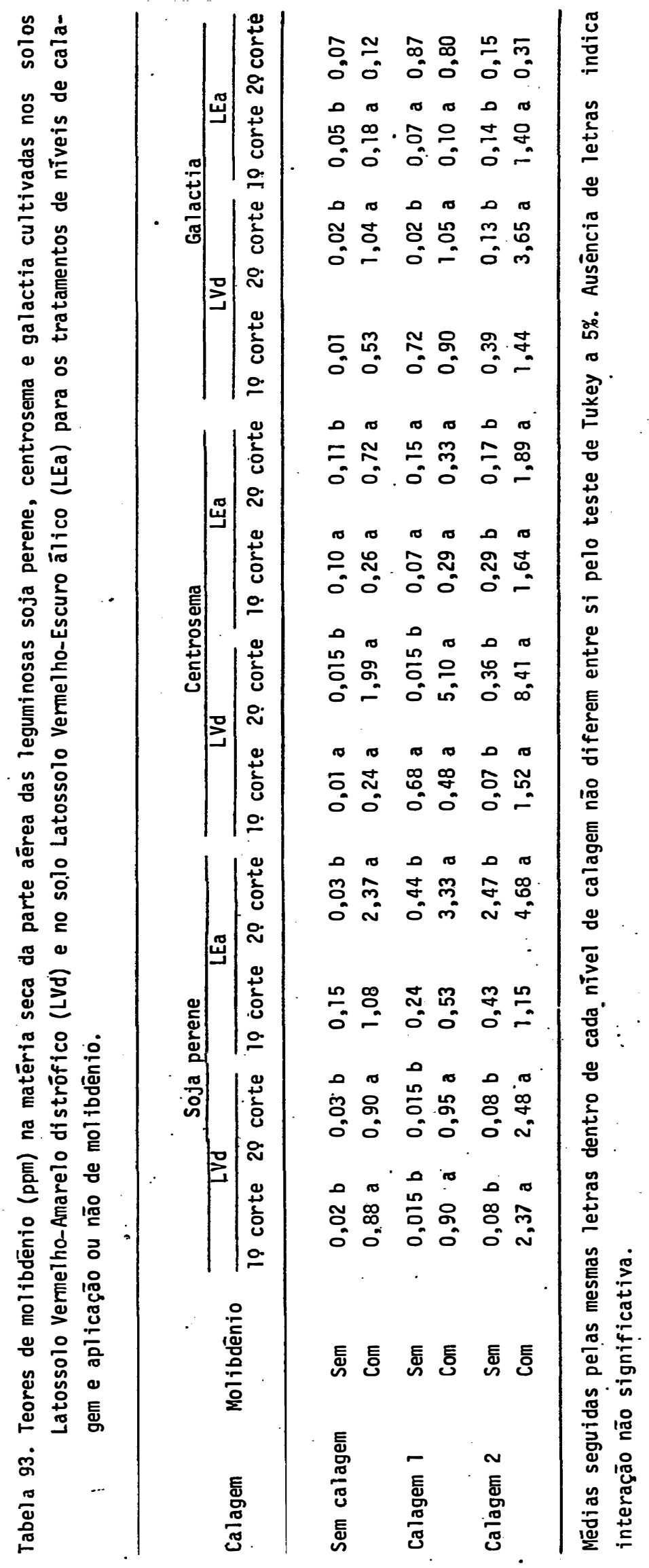




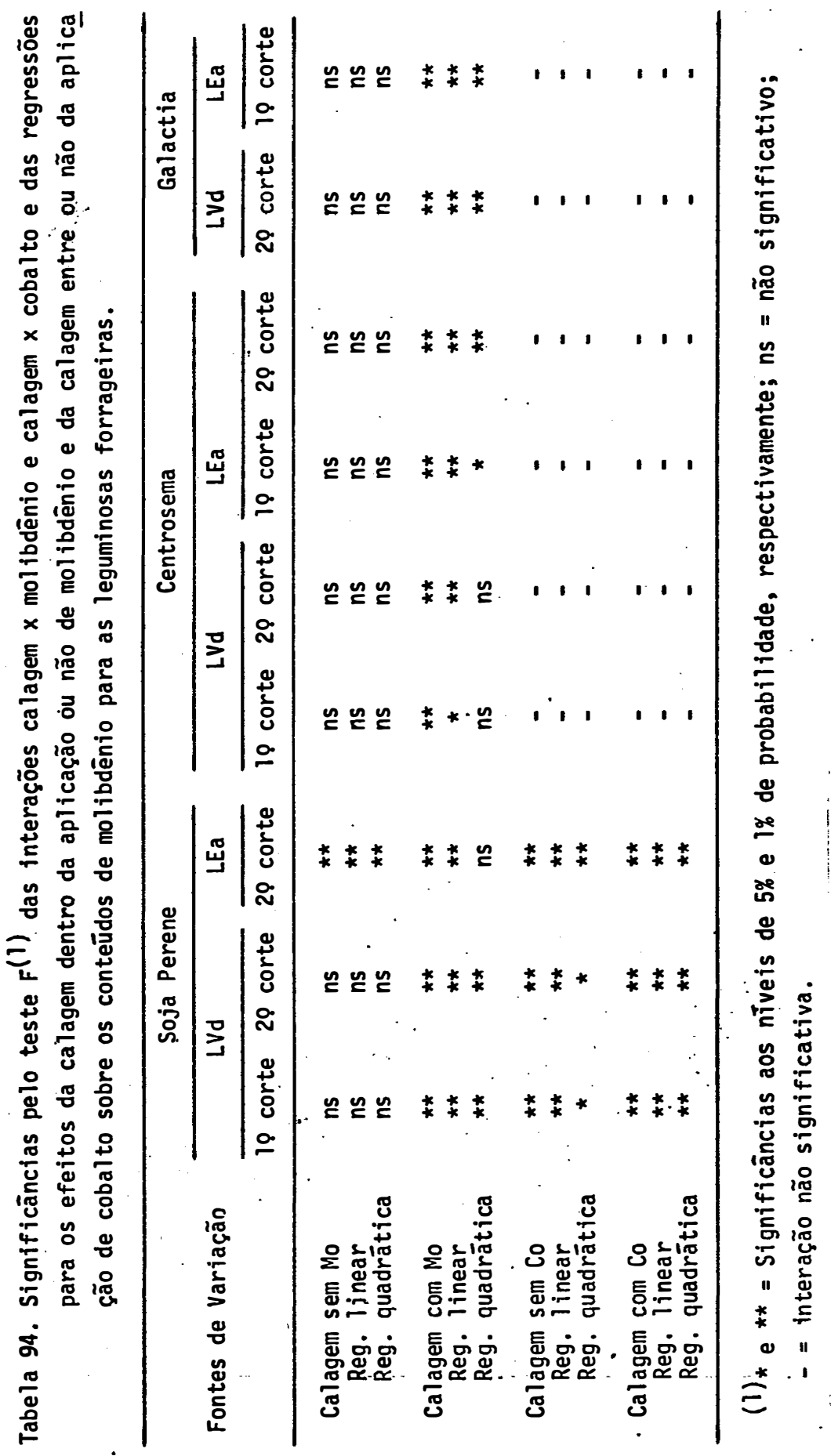


Tabela 95. Equaçōes de regreșião para os efeitos de nîveis de calagem em função dos tratamentos sem ou com aplicação dé molibdēnio.

\begin{tabular}{|c|c|c|c|c|}
\hline Laguminosa & Variāvel dependente & - Tratamentos & & Equações de Regressão $(1)$ \\
\hline \multirow[t]{3}{*}{ Soja Perene } & $\underset{\text { (LVd) }}{\text { Molibdēnio (ppm) }}$ & 19 corte - Calagem & $\begin{array}{l}\text { Sem Mo } \\
\text { Com Mo }\end{array}$ & $\bar{y}=0,88-0,020 x+0,00059 x^{2}$ \\
\hline & & 29 corte - Calagem & $\begin{array}{l}\text { Sem Mo } \\
\text { Com Mo }\end{array}$ & $\bar{y}=0,91-0,020 x+0,00061 x^{2}$ \\
\hline & (LEa) & 29 corte - Calagem & $\begin{array}{l}\text { Sem Mo } \\
\text { Com Mo }\end{array}$ & $\begin{array}{l}\bar{y}=0,03-0,012 x+0,00066 x^{2} \\
\bar{y}=2,31+0,033 x\end{array}$ \\
\hline \multirow[t]{2}{*}{ Centrosema } & $\begin{array}{l}\text { Molibdēnio }(\mathrm{ppm}) \\
\text { (LVd) }\end{array}$ & 19 corte - Calagem & $\begin{array}{l}\text { Sem Mo } \\
\text { Com Mo }\end{array}$ & $\bar{y}=0,10+0,018 x$ \\
\hline & - & 29 corte - Calagem & $\begin{array}{l}\text { Sem Mo } \\
\text { Com Mo }\end{array}$ & $\bar{y}=1,96+\begin{array}{r}\text { ns } \\
0,092 x\end{array}$ \\
\hline \multirow[t]{2}{*}{ Centrosema } & $\underset{\text { (LEa) }}{\operatorname{Molibdēnio~}(\mathrm{ppm})}$ & is corte - Calagem & $\begin{array}{l}\text { Sem Mo } \\
\text { Com Mo }\end{array}$ & $\bar{y}=0,26-0,018 x+0,00054 x^{2}$ \\
\hline & & 29 cortte - Calagem & $\begin{array}{l}\text { Sem Mo } \\
\text { Com Mo }\end{array}$ & $\bar{y}=0,72-0,039 x+0,00080 x^{2}$ \\
\hline \multirow[t]{2}{*}{ Galactia } & $\begin{array}{l}\text { Molibdēnio (ppm) } \\
\text { (LVd) }\end{array}$ & 29 corte - Calagem & $\begin{array}{l}\text { Sem Mo } \\
\text { Com Mo }\end{array}$ & $\bar{y}=1,04-\frac{n s}{n s}-0,0013 x+0,00 x^{2}$ \\
\hline & (LEa) & 19 corte - Calagem & $\begin{array}{l}\text { Sem Mo } \\
\text { Com Mo }\end{array}$ & $\ddot{y}=0,18-0,013 x+0,00031 x^{2}$ \\
\hline
\end{tabular}

(1) onde y representa a vạriāvel estudada e 0 x 0 nível de cálagem dentro dos limites utilizados. 
Tabela 96. Teores de molibdēnio (ppm) na parte aérea da soja perene e teores de cobalto (ppm) na parte aérea da galactia cultiváda nos solos Latossolo Vermelho-Amarelo distrófico (LVd) e Latossolo VermelhoEscuro ālico (LEa) em função da aplicação ou não de molibdēnio e de cobalto.

\begin{tabular}{|c|c|c|c|c|c|c|}
\hline \multirow{2}{*}{\multicolumn{2}{|c|}{ Tratamentos }} & \multicolumn{4}{|c|}{ Molibdēnio } & \multirow{3}{*}{$\frac{\text { Cobalto }}{\frac{\text { Galactia }}{\text { LEa }}}$} \\
\hline & & \multicolumn{3}{|c|}{ Soja Perene } & \multirow{2}{*}{$\frac{\begin{array}{c}\text { Soja } \\
\text { Perene }\end{array}}{\text { LVd }}$} & \\
\hline & & \multicolumn{2}{|c|}{ LVd } & \multirow{2}{*}{$\frac{\text { LEa }}{20 \text { corte }}$} & & \\
\hline & & 10 corte & 20 corte & & 20 corte & 20 corte \\
\hline \multirow[t]{2}{*}{ nolibdēnio } & Sem Co & $0,02 a$ & $0,01 a$ & $0,82 a$ & $0,25 \mathrm{~b}$ & $0,20 a$ \\
\hline & Com Co & $0,06 \mathrm{a}$ & $0,07 a$ & $1,14 a$ & $0,34 a$ & $0,31 \mathrm{~b}$ \\
\hline \multirow[t]{2}{*}{ nol ibdēnio } & Sem Co & $1,11 \mathrm{~b}$ & $1,19 \mathrm{~b}$ & $3,06 \mathrm{~b}$ & $0,23 \mathrm{~b}$ & $0,22 \mathrm{~b}$ \\
\hline & Com Co & $1,65 a$ & $1,70 a$ & $3,86 a$ & $0,26 a$ & $0,28 a$ \\
\hline
\end{tabular}

Médias seguidas pelas mesmas letras não diferem entre si pelo. teste de Tukey a $5 \%$. 
Tabela 97. Teores de molibdēnio (ppm) na parte aérea da soja-perene, em função da aplicação de calagem e de cobalto, cultivada nos solos Latossolo Vermelho-Amarelo distrōfico (LVa) e Latossolo Latossolo Vermelho-Escuro ālico (LEa).

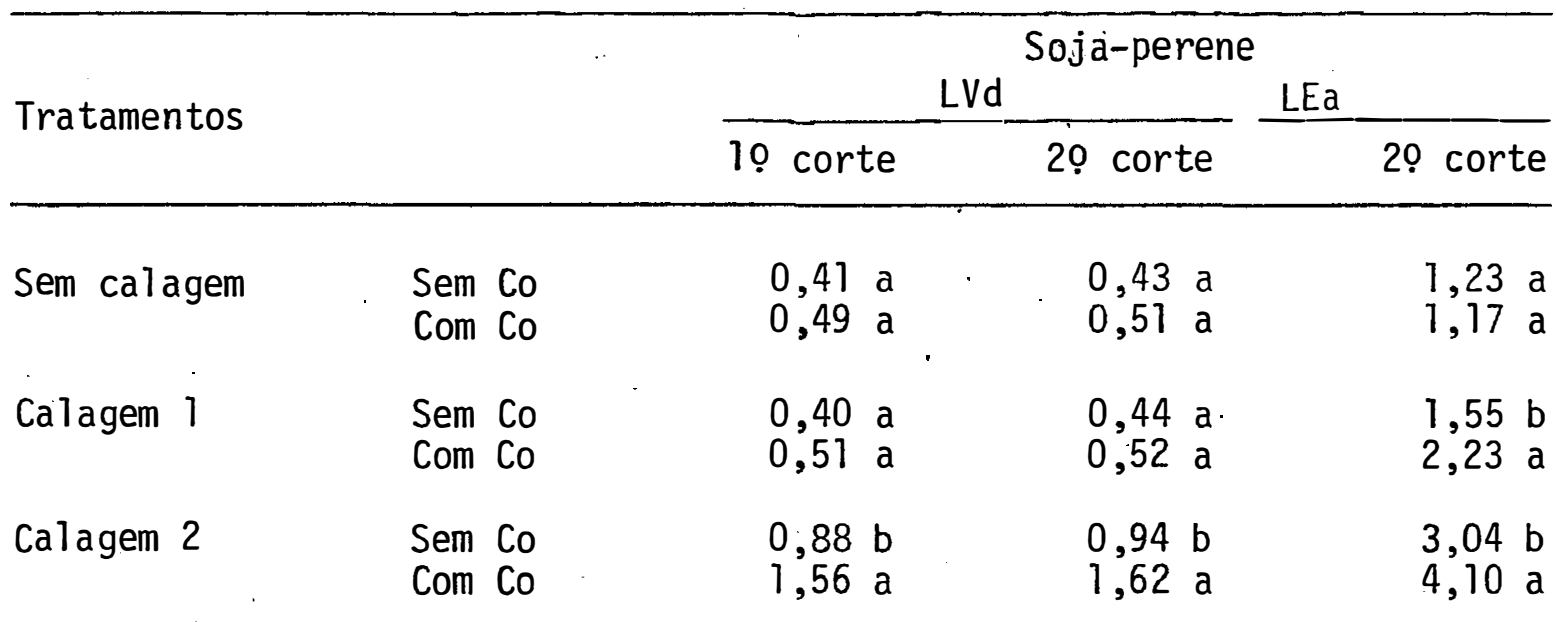

Médias seguidas pela mesma letra, no mesmo nível de calagem, não dife rem entre si pelo teste de Tukey a $5 \%$. 


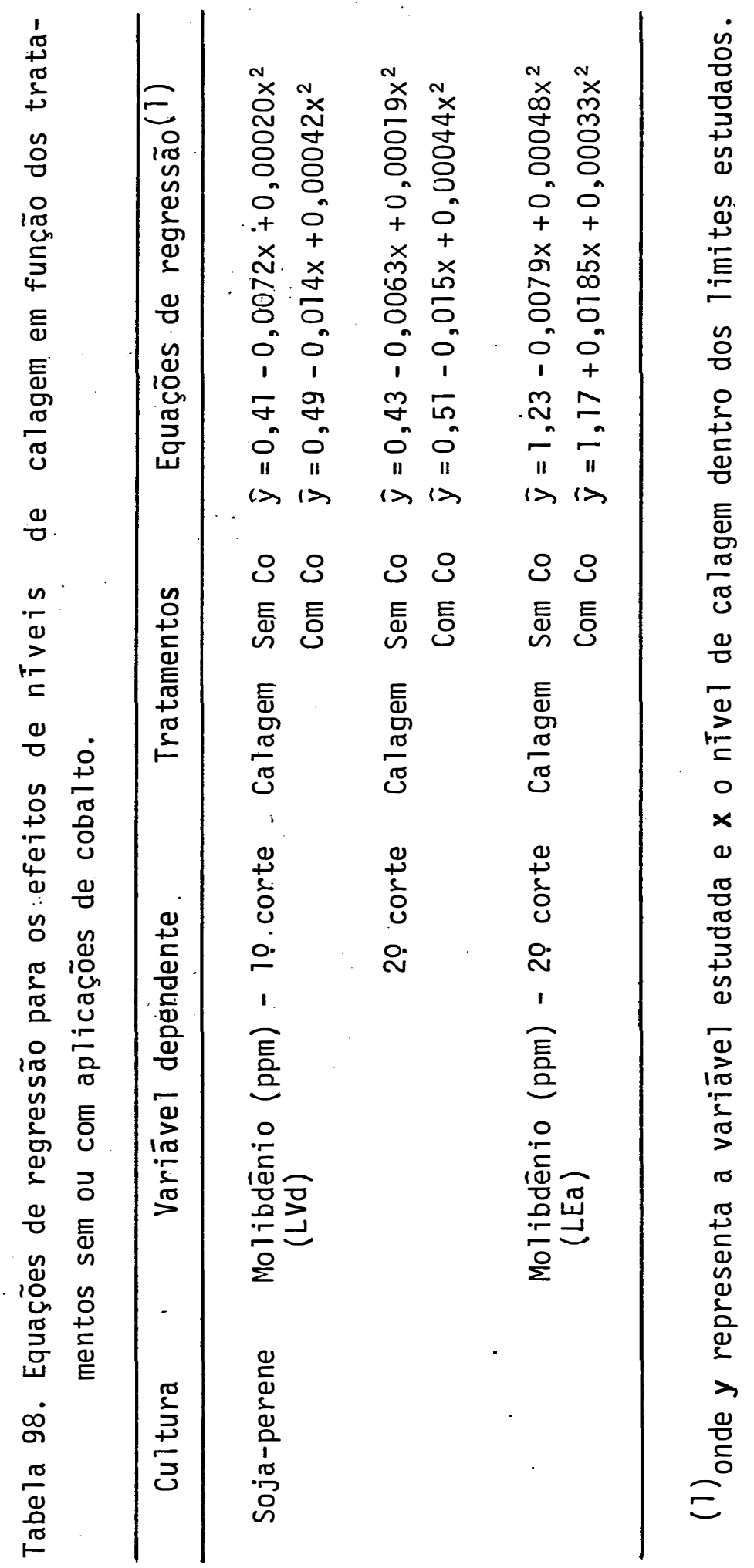




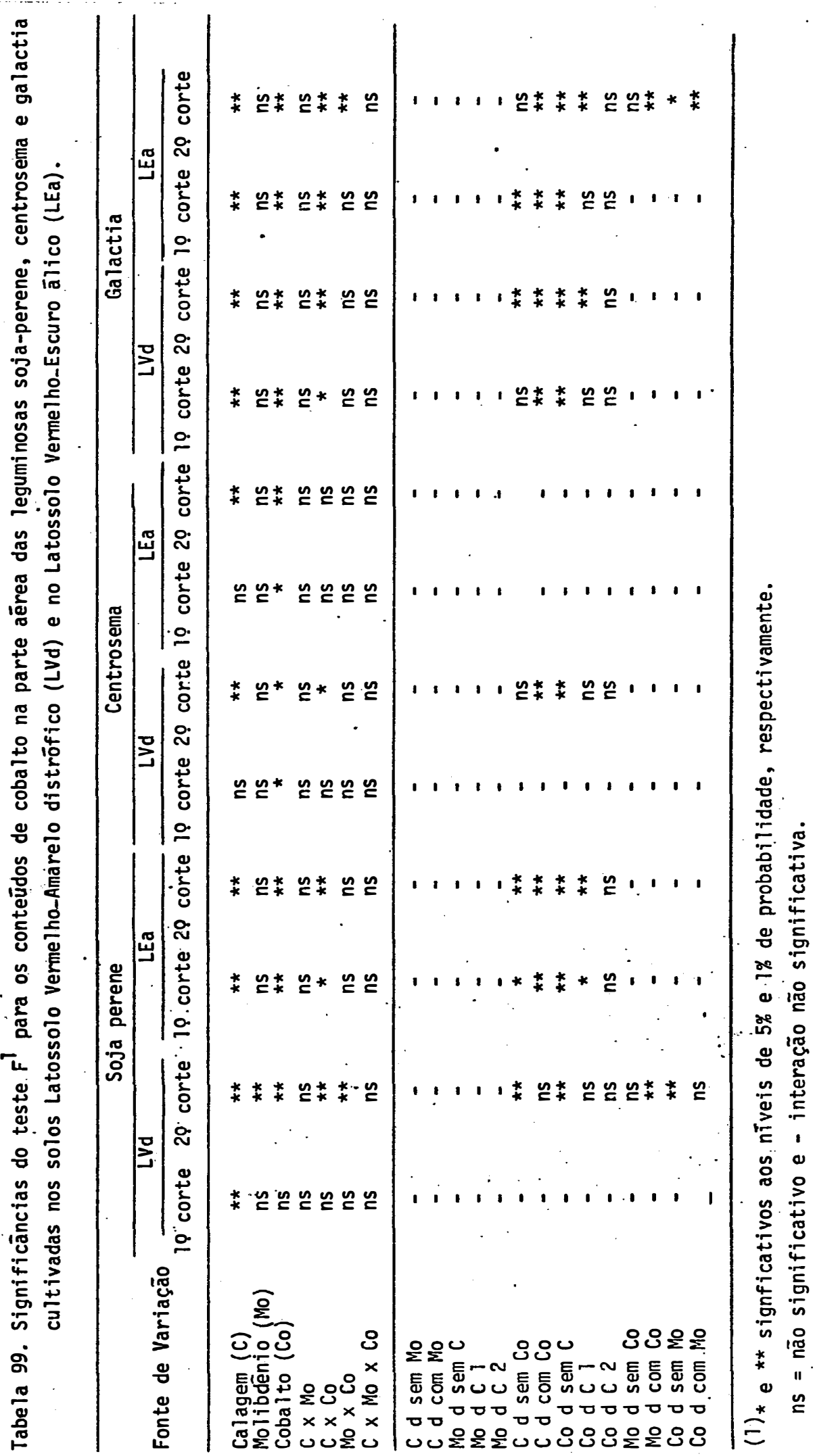




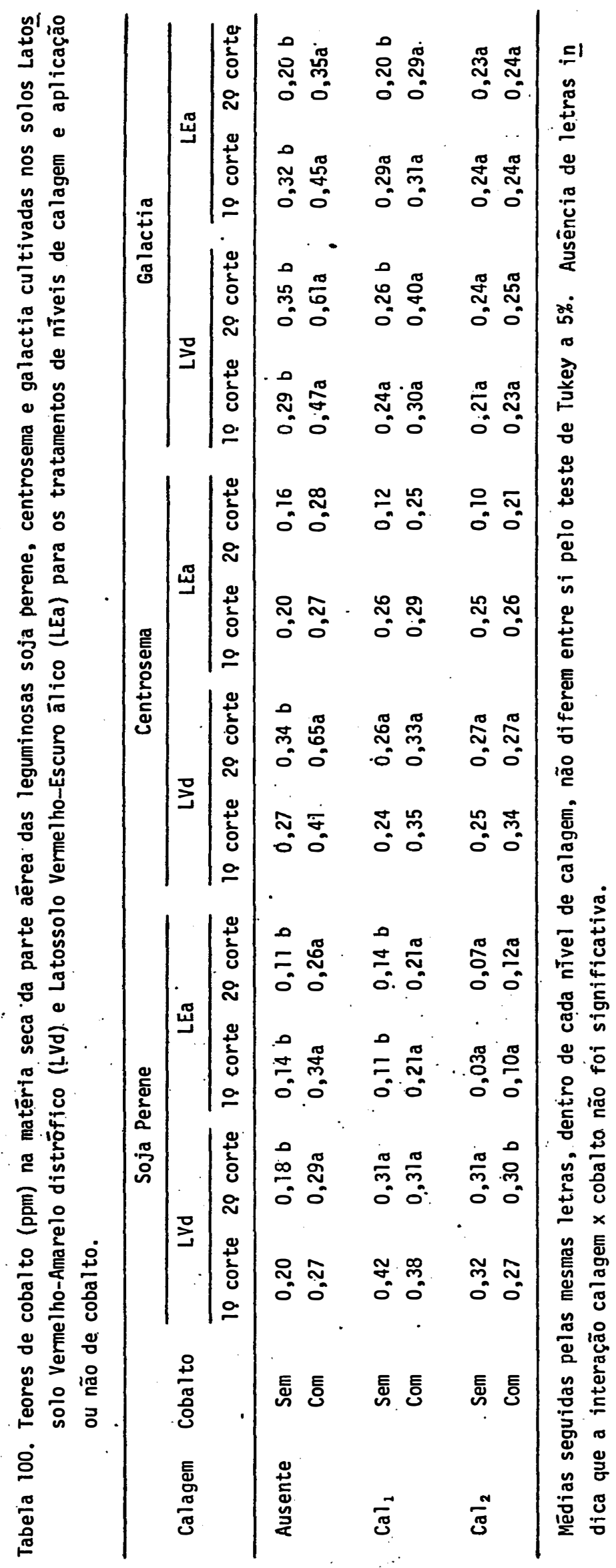




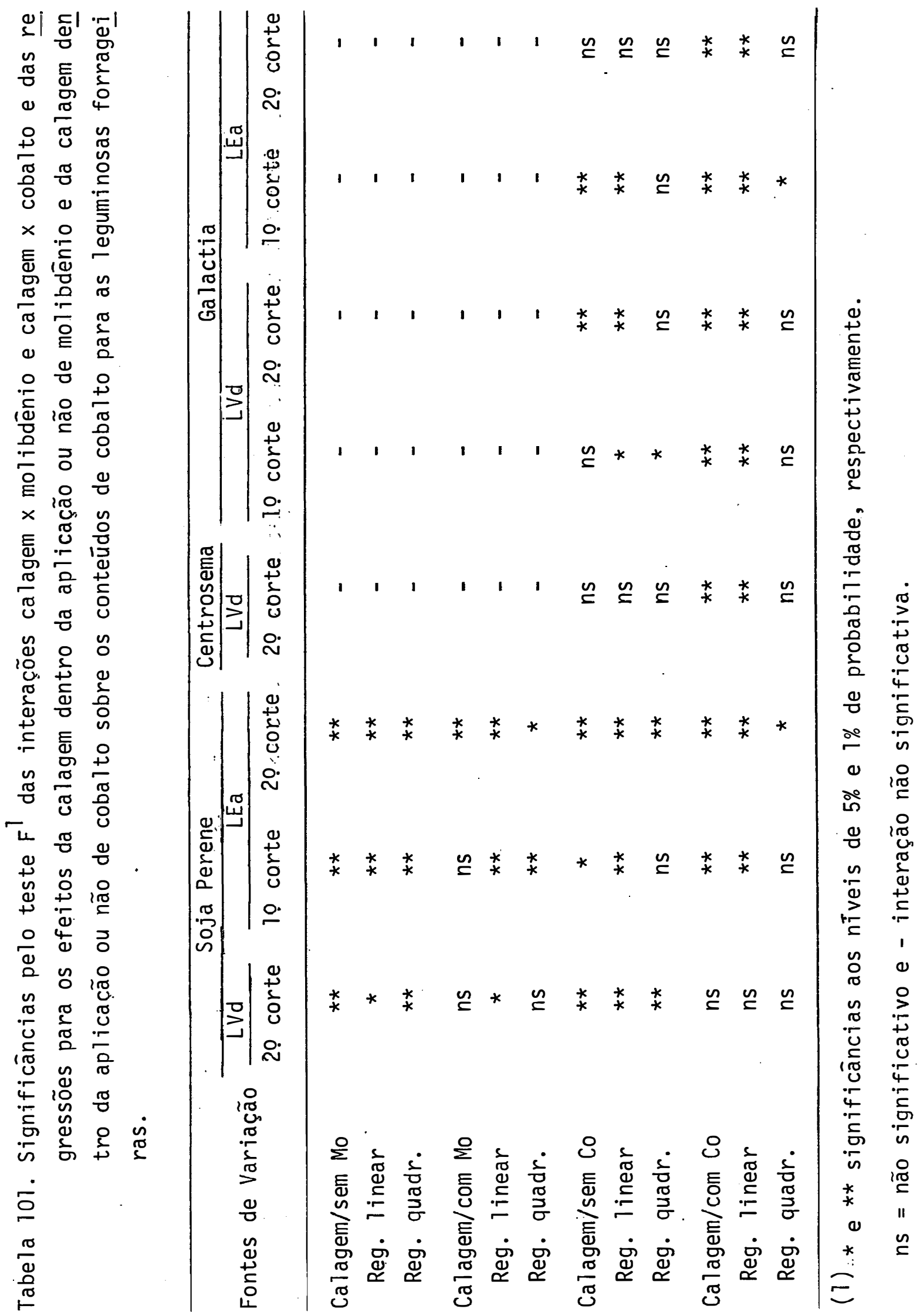




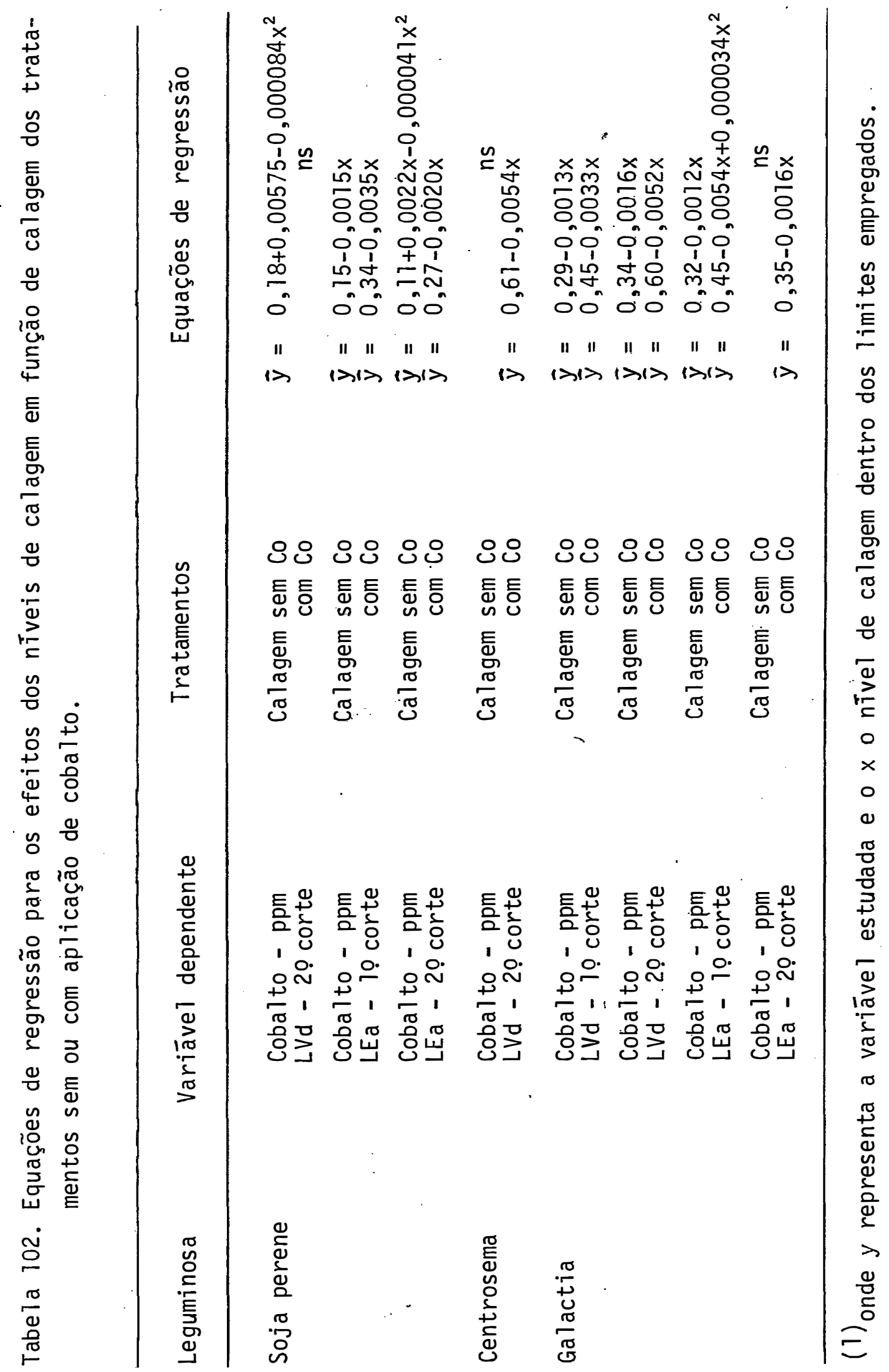

